CONTRACTOR REPORT

SAND96-0343

Unlimited Release

UC-523

RECEIVED

N.P 154998

) STI

\title{
Aging Management Guideline for Commercial Nuclear Power Plants - Tanks and Pools
}

\section{DOE}

Commercial Operating

Light Water Reactor Program

Off. of Eng. \& Tech. Dev.

19901 Germantown Rd.

Germantown, Maryland 20874

\author{
EPRI \\ Life Cycle Management Program \\ 3412 Hillview Ave. \\ P.O. Box 10412 \\ Palo Alto, California 94303
}

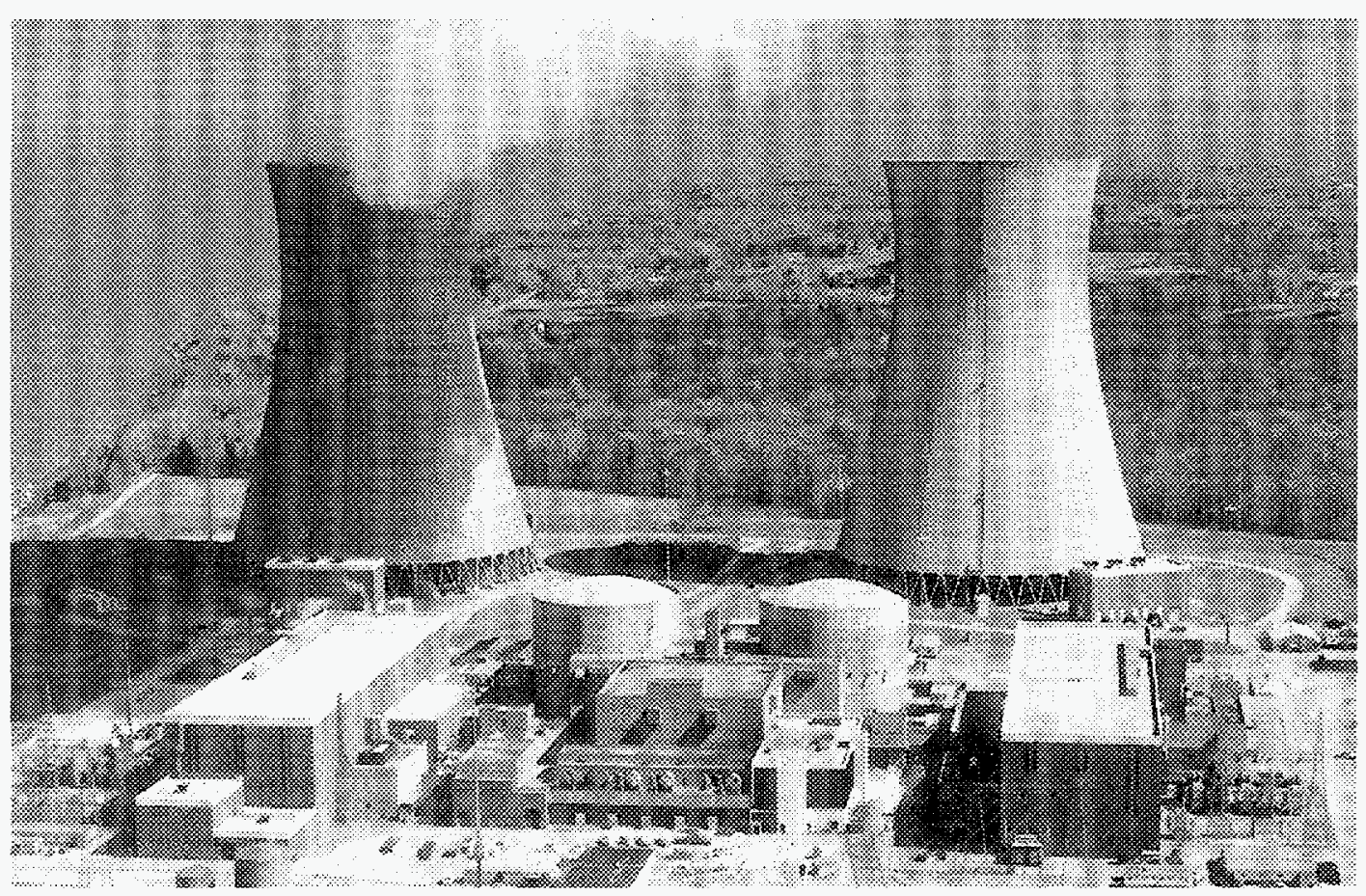

Printed February 1996

Prepared by Parsons Power, 2675 Morgantown Road, Reading, PA 19607 and Yankee Atomic Electric Corp., 580 Main St., Bolton, MA 01740, under contract to Sandia National Laboratories for the U.S. Department of Energy, in cooperation with the Electric Power Research Institute.

Funded by the U.S. Department of Energy under Contract DE-AC04-94AL85000. 
Issued by Sandia National Laboratories, operated for the United States Department of Energy by Sandia Corporation.

NOTICE: This report was prepared as an account of work sponsored by an agency of the United States Government. Neither the United States Government nor any agency thereof, nor any of their employees, nor any of their contractors, subcontractors, or their employees, makes any warranty, express or implied, or assumes any legal liability or responsibility for the accuracy, completeness, or usefulness of any information, apparatus, product, or process disclosed, or represents that its use would not infringe privately owned rights. Reference herein to any specific commercial product, process, or service by trade name, trademark, manufacturer, or otherwise, does not necessarily constitute or imply its endorsement, recommendation, or favoring by the United States

Government, any agency thereof or any of their contractors or subcontractors. The views and opinions expressed herein do not necessarily state or reflect those of the United States Government, any agency thereof or any of their contractors.

Printed in the United States of America. This report has been reproduced directly from the best available copy.

Available to DOE and DOE contractors from

Office of Scientific and Technical Information

PO Box 62

Oak Ridge, TN 37831

Prices available from (615) 576-8401, FTS 626-8401

Available to the public from

National Technical Information Service

US Department of Commerce

5285 Port Royal Rd

Springfield, VA 22161

NTIS price codes

Printed copy: A10

Microfiche copy: A01 
SAND96-0343

Distribution

Unlimited Release

Category UC-523

Printed February 1996

\title{
AGING MANAGEMENT GUIDELINE \\ FOR \\ COMMERCIAL NUCLEAR POWER PLANTS - TANKS AND POOLS
}

\author{
Prepared by: \\ Parsons Power \\ 2675 Morgantown Road \\ Reading, PA 19607 \\ and \\ Yankee Atomic Electric Company \\ 580 Main Street \\ Bolton, MA 01740 \\ Sandia Contract No. AI-5490 \\ Authors: \\ Eric Blocher, Stan Smith, \\ Lloyd Philpot, James Conley \\ Under Contract to: \\ Sandia National Laboratories \\ Albuquerque, NM 87185 \\ for the \\ U.S. Department of Energy \\ Project Manager: \\ James Nakos
}

\begin{abstract}
This Aging Management Guideline (AMG) describes recommended methods for effective detection and mitigation of aging mechanisms in commercial nuclear power plant tanks and pools within the scope of license renewal and maintenance rule activities. The intent of this AMG is to assist plant maintenance and operations personnel in maximizing the safe, useful life of these components. It also supports the documentation of aging effects management programs required under the License Renewal Rule 10 CFR 54. This AMG is presented in a manner that allows personnel responsible for performing analysis and maintenance to compare their plant-specific aging effects (expected or already experienced) and aging management program activities to the more generic results and recommendations presented herein.
\end{abstract}




\section{Acknowledgments}

This Aging Management Guideline was prepared by Parsons Power (formerly Gilbert/Commonwealth, Inc.), under the direction of the Department of Energy's Light Water Reactor Technology Center at Sandia National Laboratories, Advanced Nuclear Technology Department 6471. Funding for this report was provided by the Department of Energy, Office of Nuclear Energy, Science and Technology, Commercial Operating Light Water Reactor Programs, Dennis Harrison, Program Director. Several plants acted as "host" utilities to provide plant-specific data to help benchmark this report: Pacific Gas \& Electric, Yankee Atomic, Baltimore Gas \& Electric, and CommEd (formerly Commonwealth Edison). Their assistance is gratefully acknowledged. Review and comments were provided by members of EPRI's Life Cycle Management Subcommittee and other utility personnel; their assistance is also gratefully acknowledged. We also acknowledge survey respondents who provided additional data that assisted in the development of this report: Duke Power, Florida Power Corporation, Pennsylvania Power and Light, South Carolina Electric and Gas, PECo Energy, New York Power Authority, Vermont Yankee Nuclear Power Corporation, and Maine Yankee Atomic Power Company. Cover photograph of the Perry Nuclear Plant provided courtesy of Cleveland Electric Illuminating Company. 


\section{Disclamier}

Portions of this document may be illegible in electronic image products. Images are produced from the best available original document. 


\section{Contents}

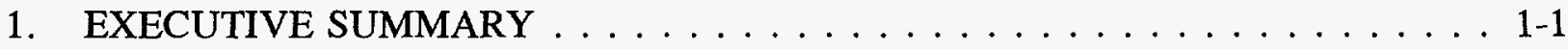

1.1 Purpose and Objectives $\ldots \ldots \ldots \ldots \ldots \ldots \ldots \ldots \ldots \ldots \ldots$

1.2 Scope ............................ . . . .

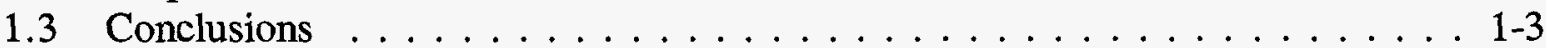

1.3.1 Aging Mechanism Conclusions ................ 1-3

1.3.2 Aging Management Program Guidelines . . . . . . . . . . . . 1-6

1.4 References . . . . . . . . . . . . . . . . . . . . . . . . 1-10

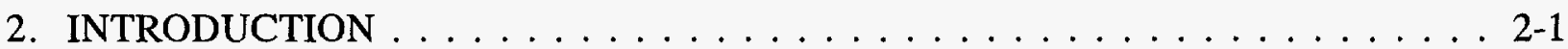

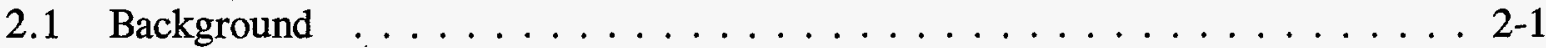

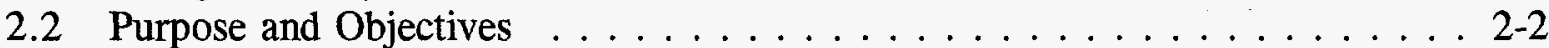

2.3 Contents of Aging Management Guideline . . . . . . . . . . . . . . . . 2-3

2.4 Generic License Renewal Requirements . . . . . . . . . . . . . . . . . . . . 2-4

2.5 Method(s) Used to Define the Scope of Components to be Evaluated Under the License Renewal Rule (LRR) and the Maintenance Rule (MR) . . . . . . . . . 2-5

2.6 Method(s) Used to Define Aging Mechanisms Assessed in This Study . . . . . 2-7

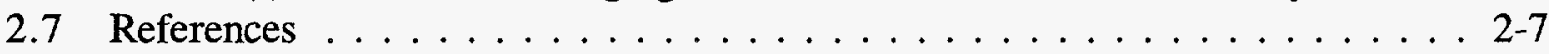

3. EQUIPMENT EVALUATED . . . . . . . . . . . . . . . . . . . . . 3-1

3.1 Results of Methodology Used to Select Components Within the Scope of the License Renewal and Maintenance Rules . . . . . . . . . . . . . . . . . . 3-1

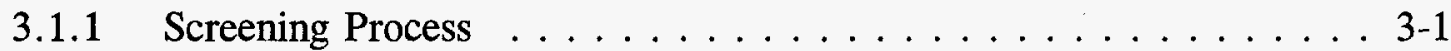

3.1.2 Identification of Tanks/Pools Within Scope of AMG . . . . . . . 3-1

3.2 Listing of Components Evaluated . . . . . . . . . . . . . . 3-2

3.2 .1 Evaluation Scope . . . . . . . . . . . . . . . . . 3-2

3.2 .2 Exclusions from Scope ......................... 3-4

3.2 .3 Tank/Pool Grouping . . . . . . . . . . . . . . . . . 3-5

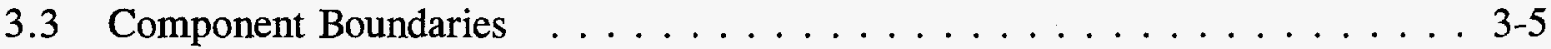

3.4 Operating and Service History $\ldots \ldots \ldots \ldots \ldots \ldots \ldots$

3.4.1 Industry-Wide Operating Experience of Components . . . . . . 3-6

3.4 .2 Trending and Analysis of Data . . . . . . . . . . . . 3-13

3.5 References .......................... 3-23

4. APPLICABLE STRESSORS AND AGING MECHANISMS . . . . . . . . . . . . 4-1

4.1 Determination of Stressors Acting on Tanks and Pools . . . . . . . . . . . 4-1

4.1.1 Mechanical Stressors . . . . . . . . . . . . . . . . . 4-2

4.1.2 Hydraulic Stressors . . . . . . . . . . . . . . . . 4 4-2

4.1 .3 Chemical Stressors . . . . . . . . . . . . . . . . . . 4-2

4.1.4 Electrical Stressors . . . . . . . . . . . . . . . . 4-3

4.1.5 Environmental Stressors . . . . . . . . . . . . . . . . 4-3

4.2 Description of Potential Tank and Pool Aging Mechanisms . . . . . . . . . 4-5

4.2 .1 Corrosion ........................ . . . . . 6

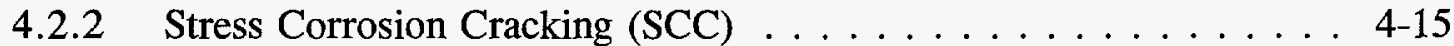

4.2 .3 Erosion/Corrosion ................... 4 $4 \ldots$

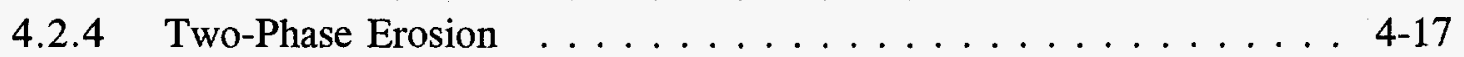


4.2.5 Intergranular Attack . . . . . . . . . . . . . . . . . . . 4-17

4.2 .6 Hydrogen Damage . . . . . . . . . . . . . . . . . . . . 4-18

4.2.7 Pool Structural Component Aging . . . . . . . . . . . . . 4-20

4.3 Aging Mechanism Significance . . . . . . . . . . . . . . . . 4-22

4.3.1 Significant Aging Mechanisms . . . . . . . . . . . . 4-22

4.3.2 Non-Significant Aging Mechanisms . . . . . . . . . . . . . . 4 4-40

4.4 Tank and Pool Aging Analysis Results . . . . . . . . . . . . . . . 4. 4-41

4.5 References . . . . . . . . . . . . . . . . . . 4-55

5. EFFECTIVE MANAGEMENT OF AGING MECHANISMS $\ldots \ldots \ldots \ldots \ldots$ 5-1

5.1 Aging Management Program Considerations . . . . . . . . . . . . . . 5-1

5.2 Common Maintenance and Surveillance Techniques/Program(s) Used . . . 5 5-2

5.2.1 ASME Section XI Inservice Inspection Program . . . . . . . . . . 5-3

5.2 .2 Preventive Maintenance Program . . . . . . . . . . . . . 5 5-4

5.2.3 Microbiologically Influenced Corrosion (MIC) Control Program . . 5 5-5

5.2.4 Other Licensing Basis Programs . . . . . . . . . . . . . . . . 5-8

5.2 .5 Operator Activities . . . . . . . . . . . . . . . 5-13

5.2.6 Protective Coatings Program . . . . . . . . . . . . . . 5 5-14

5.3 Less Common Maintenance and Surveillance Techniques/Programs Used . . 5-15

5.3 .1 Lay-up Programs . . . . . . . . . . . . . . . . . . . . 5 5-16

5.3.2 Control of External Corrosion on Underground Systems . . . . . 5 5-17

5.3.3 Tank Bladder/Diaphragm Programs . . . . . . . . . . . . . . 5 5-19

5.3.4 Leak Location Test Methods for Tanks . . . . . . . . . . . . . . . . . 5-20

5.4 Programs/Techniques Applied to Tanks/Pools . . . . . . . . . . . . . 5-21

5.4.1 Tank Aging Management Programs . . . . . . . . . . . . 5-22

5.4 Pool Aging Management Programs . . . . . . . . . . . . . 5-28

5.4.3 Aging Management Program Effectiveness Determination . . . . . 5-32

5.5 References . . . . . . . . . . . . . . . . . . . . . . . . . . . 5-34

6. OTHER AGING MANAGEMENT CONSIDERATIONS . . . . . . . . . 6 6-1

6.1 Cathodic Protection (Corrosion Prevention) . . . . . . . . . . . . 6-1

6.1 .1 Impressed Current Systems . . . . . . . . . . . . . . . 6-1

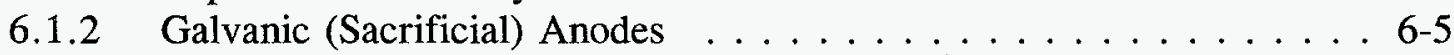

6.2 Environmental Considerations . . . . . . . . . . . . . . . 6-9

6.2 .1 Underground Storage Tanks (UST) . . . . . . . . . . . 6-9

6.2 .2 Above-ground Storage Tanks (AST) $\ldots \ldots \ldots \ldots \ldots$. . . . . . . . . .

6.2.3 Environmental Performance Requirements . . . . . . . . . . . . 6-11

6.3 Use of Composite Tanks . . . . . . . . . . . . . . . . . . . . . 6 6-11

6.4 Pulsed Infrared Imaging Inspection of AST . . . . . . . . . . . . 6-15

6.5 Eddy Current and Magnetic Flux Leakage of Tank Bottoms . . . . . . . . 6-16

6.6 References . . . . . . . . . . . . . . . . . . . . 6-16

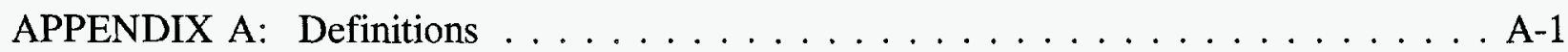

APPENDIX B: Acronyms . . . . . . . . . . . . . . . . B-1

APPENDIX C: Industry Codes and Standards for Tanks $\ldots \ldots \ldots \ldots \ldots \ldots$ C-1

APPENDIX D: Data Survey Forms . . . . . . . . . . . . . . . D-1

APPENDIX E: Non-Significant Aging Mechanism Descriptions . . . . . . . . E-1 
Figures

3-1 Typical Vertical Free-Standing Tank. . . . . . . . . . . . . . . . . 3-7

3-2 Typical Horizontal (Supported) Tank. . . . . . . . . . . . . . . . . . . . . 3-8

3-3 Typical BWR Spent Fuel Pool at Plants with Mark I or II Containments . . . . . 3-9

3-4 NPRDS Records from Search for Accumulators . . . . . . . . . . . . . . . 3-15

3-5 Tank Failures from NPRDS Data Evaluated in this AMG . . . . . . . . . . . 3-15

3-6 LER Records from Search for Vessels Evaluated in AMG . . . . . . . . . . . 3-17

4-1 Tank and Pool Austenitic Stainless Steel Aging Analysis Diagram. . . . . . . . 4-26

4-2 Carbon Steel Tank and Pool Aging Analysis Diagram. . . . . . . . . . . . 4 4-33

5-1 Determination of Aging Management Practices. . . . . . . . . . . . . . . . 5-24

5-2 Tank Aging Management Program Element Hierarchy . . . . . . . . . . . 5-26

6-1 Typical Impressed Current Cathodic Protection System Schematic Diagram (non-automatic) . . . . . . . . . . . . . . . . . . . . . 6-2

6-2 Schematic Diagram for Automatic Potential Control Systems . . . . . . . . . . 6-4

6-3 Life of Zinc Anode vs. Current Output . . . . . . . . . . . . . . . . . 6-7

6-4 and 6-5. Current Outputs of Zinc Anodes as a Function of Soil Resistivity and

Driving Potential. . . . . . . . . . . . . . . . . . 6-8 


\section{Tables}

1-1 Tanks/Pools in Scope of AMG . . . . . . . . . . . . . . . . . 1-2

1-2 Aging Mechanisms Evaluated . . . . . . . . . . . . . . . . 1-4

1-3 Summary of Potentially Significant Tank/Pool Aging Mechanisms . . . . . . . . 1-5

1-4 Tank Aging Effects and Aging Management Program Evaluation . . . . . . . . 1-7

1-5 Pool Aging Effects and Aging Management Program Evaluation . . . . . . . . . . 1-8

1-6 Typical Frequencies of Tanks/Pools Aging Management Programs . . . . . . . . 1-9

1-7 Framework for Basic Tank System Aging Management Program . . . . . . . . 1-10

2-1 License Renewal Rule and Maintenance Rule Scope Screening Requirements . . . 2-6

3-1 Tanks/Pools in Scope of AMG . . . . . . . . . . . . . . . . . . 3-3

3-2 Systems Which Contain Tanks and Pools Evaluated in this AMG . . . . . . . 3-11

3-3 NPRDS Records from Search for Accumulators . . . . . . . . . . . . . . . . 3-14

3-4 LER Records from Search for Vessels . . . . . . . . . . . . . . . . . . . . . 3-16

3-5 LER Records from Search for Pools . . . . . . . . . . . . . . . . . . . . . . . 3-16

3-6 Industry Information on Tanks and Pools . . . . . . . . . . . . . . 3-18

3-7 SOERs and SERs Applicable to Tanks and Pools . . . . . . . . . . . . . 3-19

3-8 Industry Standards for Tanks/Pools . . . . . . . . . . . . . . . . . 3-21

3-9 Initial Code/Standard Considerations in Selecting Scope of AMG . . . . . . . 3-22

4-1 Galvanic Series . . . . . . . . . . . . . . . . . . . . . . . 4 4-4

4-2 Potentially Significant Aging Mechanisms for Tanks and Pools . . . . . . . . . . 4-7

4-3 Non-Significant Aging Mechanisms for Tanks and Pools . . . . . . . . . . . . 4-9

4-4 Aging Mechanism Key Decision Parameters . . . . . . . . . . . . . . . . . 4-23

4-5 Tank Aging Mechanisms Evaluated . . . . . . . . . . . . . . . . . . . . 4-42

4-6 Summary of Potentially Significant Tank/Pool Aging Mechanisms . . . . . . . . 4-43

4-7 Tank and Pool Aging Analysis Results from Host Utility Data . . . . . . . . . 4 4-44

5-1 Summary of Potentially Significant Tank/Pool Aging Mechanisms . . . . . . . 5 5-23

5-2 Tank Aging Effects and Aging Management Program Evaluation . . . . . . . 5 5-27

5-3 Framework for Basic Tank System Aging Management Program . . . . . . . . . 5-29

5-4 Typical Frequencies of Tanks/Pools Aging Management Programs . . . . . . . 5-30

5-5 Pool Aging Effects and Aging Management Program Evaluation . . . . . . . . 5-33

6-1 Typical Galvanic Anode Material Consumption Rates . . . . . . . . . . . . . 6-9

6-2 Environmental Considerations for Storage Tanks . . . . . . . . . . . . 6-11 


\section{AGING MANAGEMENT GUIDELINE FOR TANKS AND POOLS}

\section{EXECUTIVE SUMMARY}

Continued operation of nuclear power plants for periods that extend beyond their original 40-year license period is a desirable option for many U.S. utilities. U.S. Nuclear Regulatory Commission (NRC) approval of operating license renewals is necessary before continued operation becomes a reality. Effective aging management for plant components is important to reliability and safety, regardless of current plant age or extended life expectations. However, the NRC requires that aging evaluations be performed and the effectiveness of aging management programs be demonstrated for components considered within the scope of license renewal before granting approval for operation beyond 40 years. Both the NRC and the utility want assurance that plant components will be highly reliable during both the current license term and throughout the extended operating period. In addition, effective aging management must be demonstrated to support Maintenance Rule (10 CFR 50.65) activities.

\subsection{Purpose and Objectives}

The purpose of this aging management guideline (AMG) is to provide guidance for effective aging management of a selected group of tanks and pools which are important to safe and reliable nuclear power plant operation. The applications studied are those found in both Boiling Water Reactor (BWR) and Pressurized Water Reactor (PWR) facilities. The primary target audience for this AMG is plant engineering, operations, and maintenance personnel, although it will also be of interest to those involved with nuclear plant aging management programs. The AMG is presented in a manner which allows personnel responsible for performing analysis and maintenance to compare their plant-specific tanks and pools aging effects/mechanisms (expected or already experienced) and aging management program activities to the more generic results and recommendations presented in this AMG.

\subsection{Scope}

The nuclear plant tanks and pools included in the scope of this AMG are listed in Table 1-1. This listing includes all major tanks and pools which have been identified as within license renewal and maintenace rule scope based on the NRC criteria provided in 10 CFR 54 (License Renewal)[1.1] and 10 CFR 50.65 (Maintenance Rule).[1.2] The aging evaluation (Section 4) and effective program evaluation (Section 5) encompass all of these tanks and pools. Utility personnel should verify that their tanks and pools are within the scope of this AMG prior to applying the results and recommendations.

The strategy for preparing this AMG includes (1) identifying the tanks and pools materials, design parameters, and typical operating conditions, and (2) collecting and evaluating tanks and pools operating/maintenance history information, identifying the stressors acting on these tanks and pools, and determining the significance of tank and pool aging mechanisms 


\begin{tabular}{|c|c|}
\hline BWR Tanks/Pools & PWR Tanks/Pools \\
\hline $\begin{array}{l}\text { TANKS } \\
\text { - Condensate Storage Tank (clean) (1) } \\
\text { - Condensate Storage Tank (contaminated) } \\
\text { - Diesel Fuel Storage Tank } \\
\text { - Diesel Fuel Day Tank } \\
\text { - Fire Water Storage Tank } \\
\text { - Fuel Pool Skimmer Surge Tank } \\
\text { - Fuel Pool Drain Tank (1) } \\
\text { - High-Pressure Core Spray Floor Pit/Tank } \\
\text { - Reactor Building Closed Cooling Water } \\
\text { Tank } \\
\text { - Standby Liquid Storage Tank }\end{array}$ & $\begin{array}{l}\text { TANKS } \\
\text { - Condensate Storage Tank } \\
\text { - Diesel Fuel Storage Tank } \\
\text { - Diesel Fuel Day Tank } \\
\text { - Fire Water Storage Tank } \\
\text { - Boric Acid Tanks } \\
\text { - Demineralized Water Tank (1) } \\
\text { - Containment Spray Additive Tank } \\
\text { - Refueling Water Storage Tank } \\
\text { - Component Cooling Water System Surge } \\
\text { Tank } \\
\text { - Volume Control Tank } \\
\text { - Isolation Valve Seal Water Tank }\end{array}$ \\
\hline $\begin{array}{l}\text { POOLS } \\
\text { Spent Fuel Pool }\end{array}$ & $\begin{array}{l}\text { POOLS } \\
\text { Spent Fuel Pool }\end{array}$ \\
\hline
\end{tabular}

Notes:

(1) Included for completeness (pressure vessel or non-safety tank)

(2) Includes Containment Spray Storage Tanks (CE design) and Borated Water Storage Tanks (B\&W design)

(3) Includes Fuel Holding Pool, Transfer Canal, Refueling Cavity, and Upper Containment Fuel Storage Pool

(4) Called a "Makeup Water Tank" in B\&W designed plants

and associated aging effects. After completing these tasks and reviewing currently utilized aging management practices, guidelines are presented for effective aging management of these tanks and pools.

Input for development of this AMG includes design data, operating/maintenance history (including degradation findings and failure incidents), and current inspection, testing, and maintenance program activities. The information is obtained from a variety of sources including NRC publications, computerized industry databases, tanks and pools industry literature, individual nuclear plant records, and aging management reports and papers prepared by the Electric Power Research Institute (EPRI), the U.S. Department of Energy (DOE), and engineering consultants. 
This AMG evaluates all aging mechanisms for the tanks and pools listed in Table 1-1. Section 4 examines aging mechanisms and the effects of aging to determine which are non-significant and which are potentially significant. Section 5 examines aging management programs/techniques to determine which are effective for detecting and/or mitigating the significant aging mechanisms and corresponding effects of aging. The tanks and pools contain several different fluid types, and were constructed from different material types and operating modes. Unique differences exist between plants with respect to tanks and pools type, materials, and operating parameters for similar service applications. To account for this diversity, some consolidation and simplification was necessary, but the generalized results will still be useful to all plants. However, utilities may have to do some plant-specific analysis.

Common characteristics of tank and pool designs and service applications are examined to establish groupings for aging mechanism and aging management program/technique evaluations.

The primary characteristic for grouping selected tanks and pools is the material and process fluid. It is not possible for this AMG to cover all plant-unique situations. Therefore, it is necessary to identify a generic standard that is representative of a majority of the existing plant applications with regard to tank and pool design, materials, operating parameters, and safety function classification. The determination of (1) potential significance/non-significance for specific aging mechanisms, (2) aging mechanism/component combinations, (3) effects of potential aging mechanisms, and (4) applicability of aging management programs/techniques is, therefore, based on this generic standard. These qualifications or conditions are presented in an if/then format (i.e., if there are no cyclic stresses, then fatigue is a non-significant aging mechanism). With these qualifications, plant personnel can uniquely determine how the AMG results are applicable to their specific applications.

\subsection{Conclusions}

\subsubsection{Aging Mechanism Conclusions}

The tank and pool aging mechanisms evaluated in this report are listed in Table 1-2. Table 1-3 summarizes the significance of the aging mechanisms with respect to tank and pool material and process fluid grouping components.

The generic examinations in Section 4 showed that selected combinations of tank component materials and fluid applications were susceptible to corrosion (general, crevice pitting, selective leaching, galvanic, or microbiologically influenced), stress corrosion cracking (intergranular stress corrosion cracking (IGSCC) and transgranular stress corrosion cracking (TGSCC)), erosion/corrosion and two-phase erosion and intergranular attack. The fluid service examinations in Section 4 were able to establish non-significance thresholds for various aging mechanisms associated with various tank subcomponents based on metallurgy and design characteristics. Similarly, for pools, potentially significant aging mechanisms are liner corrosion, steel embedment/rebar corrosion, and concrete degradation from aggressive chemicals. The effects of aging on tanks/pools are cracking, wall thinning, pitting, concrete spalling, erosion, and cracking. 
Table 1-2. Aging Mechanisms Evaluated (Potentially significant aging mechanisms in Section 4, non-significant aging mechanisms in Appendix E)

\begin{tabular}{|c|c|c|c|}
\hline Section & Potential Aging Mechanism & $\begin{array}{l}\text { Potentially } \\
\text { Significant }\end{array}$ & $\begin{array}{c}\text { Not } \\
\text { Significant }\end{array}$ \\
\hline \multirow[t]{5}{*}{ 4.2.1 Corrosion } & General Corrosion & $\checkmark$ & \\
\hline & Selective Leaching & $\checkmark$ & \\
\hline & Pitting and Crevice Corrosion & $\checkmark$ & \\
\hline & Galvanic Corrosion & $\checkmark$ & \\
\hline & MIC & $\checkmark$ & \\
\hline \multirow{3}{*}{$\begin{array}{l}\text { 4.2.2 Stress Corrosion Cracking } \\
\text { (SCC) [Section E.2] }\end{array}$} & IGSCC & $\mathscr{l}$ & \\
\hline & IASCC [Section E.2] & & $\checkmark$ \\
\hline & TGSCC & $\checkmark$ & \\
\hline 4.2.3 Erosion/Corrosion & Erosion/Corrosion & $\checkmark$ & \\
\hline 4.2.4 Two-Phase Erosion & Two-Phase Erosion & $\checkmark$ & \\
\hline 4.2.5 Intergranular Attack & Intergranular Attack & $\checkmark$ & \\
\hline 4.2.6 Hydrogen Damage & Hydrogen Damage & $\checkmark$ & \\
\hline \multirow[t]{2}{*}{ 4.2.7 Structural Aging (Pools) } & Aggressive Chemicals & $\checkmark$ & \\
\hline & $\begin{array}{l}\text { Corrosion of Embedded Steel/ } \\
\text { Rebar }\end{array}$ & $\checkmark$ & \\
\hline E.1 Fatigue [Appendix E] & Fatigue & & $\checkmark$ \\
\hline \multirow[t]{8}{*}{ E.3.1 Thermal Embrittlement } & $475^{\circ} \mathrm{C}$ Embrittlement & & $\checkmark$ \\
\hline & Temper Embrittlement & & $\boldsymbol{L}$ \\
\hline & $350^{\circ} \mathrm{C}$ Embrittlement & & $\checkmark$ \\
\hline & Blue Brittleness & & $\checkmark$ \\
\hline & Strain-Age Embrittlement & & $\checkmark$ \\
\hline & Graphitization Embrittlement & & $\checkmark$ \\
\hline & Sigma Phase Embrittlement & & $\checkmark$ \\
\hline & $400-500^{\circ} \mathrm{C}$ Embrittlement & & $\checkmark$ \\
\hline E.3.2 Neutron Embrittlement & Neutron Embrittlement & & $\checkmark$ \\
\hline \multirow[t]{3}{*}{ E.4 Wear } & Adhesive Wear & & $\checkmark$ \\
\hline & Abrasive Wear & & $\checkmark$ \\
\hline & Erosion & & $\checkmark$ \\
\hline E.5 Stress Relaxation & Stress Relaxation & & $\checkmark$ \\
\hline E.6 Creep & Creep & & $\checkmark$ \\
\hline
\end{tabular}




\section{AGING MANAGEMENT GUIDELINE FOR TANKS AND POOLS}

\begin{tabular}{|c|c|c|c|c|c|c|c|c|c|c|c|c|c|}
\hline Material & $\begin{array}{l}\text { Fluid } \\
\text { Type }\end{array}$ & $\begin{array}{l}\text { General } \\
\text { Corrosion }\end{array}$ & $\begin{array}{l}\text { Selective } \\
\text { Leaching }\end{array}$ & $\begin{array}{l}\text { Crevice } \\
\text { Pitting } \\
\text { Corrosion }\end{array}$ & $\begin{array}{l}\text { Galvanic } \\
\text { Corrosion }\end{array}$ & MIC & $\begin{array}{l}\text { IG } \\
\text { SCC }\end{array}$ & $\begin{array}{l}\text { TG } \\
\text { SCC }\end{array}$ & $\begin{array}{l}\text { Erosion } \\
\text { Corrosion }\end{array}$ & $\begin{array}{l}\text { Two- } \\
\text { Phase } \\
\text { Erosion }\end{array}$ & IGA & $\begin{array}{l}\text { Hydrogen } \\
\text { Damage } \\
\text { (Note 2) }\end{array}$ & $\begin{array}{l}\text { Issue } \\
\text { Summary }\end{array}$ \\
\hline Austenitic SS & $\begin{array}{l}\text { Raw } \\
\text { Water }\end{array}$ & 1): & No: & Yes & $18 \%$ & Yes & Yes & Yes & $\sqrt{1}$ & 18. & 10. & No & Yes \\
\hline \multirow[t]{5}{*}{ Carbon Steel } & Air & Yes & Nito: & $10:$ & r. & $10 \%$ & 40 & r. & $\sqrt{1 \%}$ & 14. & $1 \%$ & No & Yes \\
\hline & $\begin{array}{l}\text { Fuel } \\
\text { Oil }\end{array}$ & Yes & Niv: & Yes & 18 & Yes & 1. & i: & 1. & 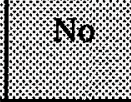 & $4 \%$ & No & Yes \\
\hline & $\begin{array}{l}\text { Clean } \\
\text { Water }\end{array}$ & Yes & rivo & Yes & 48 & 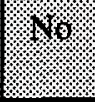 & No. & 11 & 110. & $18 \%$ & 110 & No & Yes \\
\hline & $\begin{array}{l}\text { Raw } \\
\text { Water }\end{array}$ & Yes & No: & Yes & 16: & Yes & \% & 16. & $1 \%$ & 10: & 10 & No & Yes \\
\hline & $\begin{array}{l}\text { Wet } \\
\text { Steam }\end{array}$ & Yes & 1.8: & 18 & 1918 & 1.8. & $\sqrt{2}$ & $8 \%$ & $11 \%$ & Yes & 110. & No & Yes \\
\hline $\begin{array}{l}\text { Reinforced } \\
\text { Concrete } \\
\text { (Pools only) }\end{array}$ & $\begin{array}{l}\text { Borated } \\
\text { Water }\end{array}$ & \begin{tabular}{|l} 
Yes \\
See Note \\
1
\end{tabular} & 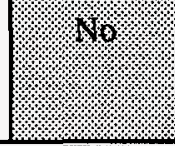 & 180 & $11 \%$ & 1.1. & 4 & $1 \%$ & 10 & $1 \%$ & r. & No & Yes \\
\hline \multicolumn{14}{|c|}{$\begin{array}{l}\text { Note 1: Based on structural aging mechanisms associated with aggressive chemical attack and corrosion of embedments. } \\
\text { Note 2: Hydrogen damage is only a concern for carbon steel, when cathodic protection is used, and when the voltage potential is incorrectly } \\
\text { set. }\end{array}$} \\
\hline
\end{tabular}




\subsubsection{Aging Management Program Guidelines}

The aging management programs that effectively manage the significant aging mechanism/effect for each tank/pool material and fluid application are discussed in Section 5.

The aging management programs presented in this AMG are summarized in the tables noted below. Tables 1-4 and 1-5 relate the aging management program to the significant aging mechanism and associated aging effect for the individual tank/pool material/fluid groups. Table 1-6 identifies routine, periodic, and one-time evaluation frequency considerations for tanks/pools aging management programs. Table 1-7 provides a basic program framework when evaluating aging management programs for individual tanks. 
AGING MANAGEMENT GUIDELINES FOR TANKS AND POOLS

\begin{tabular}{|c|c|c|c|c|c|c|}
\hline $\begin{array}{c}\text { Tank System } \\
\text { (Material / Fluid) }\end{array}$ & Aging Mechanism & $\begin{array}{l}\text { Aging } \\
\text { Effect }\end{array}$ & $\begin{array}{l}\text { Likelihood } \\
\text { of } \\
\text { occurrence }\end{array}$ & $\begin{array}{c}\text { Consequence if } \\
\text { prompt actions } \\
\text { are taken }\end{array}$ & $\begin{array}{l}\text { Preventive } \\
\text { Programs }\end{array}$ & $\begin{array}{l}\text { Mitigative } \\
\text { Programs }\end{array}$ \\
\hline $\begin{array}{l}\text { Stainless Steel/ } \\
\text { Raw Water }\end{array}$ & $\begin{array}{c}\text { TGSCC } \\
\text { IGSCC } \\
\text { Crevice Pitting } \\
\text { MIC }\end{array}$ & $\begin{array}{l}\text { Pitting } \\
\text { Cracking }\end{array}$ & $\mathrm{H}^{1}$ & $\mathrm{~L}^{2}$ & $\begin{array}{l}\text { Preventive Maintenance Program } \\
\text { Raw Water Program } \\
\text { MIC Control Program }\end{array}$ & $\begin{array}{l}\text { ISI Program } \\
\text { Maintenance Rule Program } \\
\text { Operator Activities }\end{array}$ \\
\hline $\begin{array}{c}\text { Carbon Steel } \\
\text { Air }\end{array}$ & Corrosion & Wall Thinning & $\mathrm{L}$ & $\mathrm{L}$ & $\begin{array}{l}\text { Preventive Maintenance Program } \\
\text { Coating Surveillance Program }\end{array}$ & $\begin{array}{l}\text { ISI Program } \\
\text { Maintenance Rule Program } \\
\text { Operator Activities }\end{array}$ \\
\hline $\begin{array}{l}\text { Carbon Steel/ } \\
\text { Fuel Oil }\end{array}$ & $\begin{array}{c}\text { Corrosion } \\
\text { Crevice Pitting } \\
\text { MIC }\end{array}$ & $\begin{array}{l}\text { Wall Thinning } \\
\text { Pitting } \\
\text { Cracks }\end{array}$ & $\mathbf{H}$ & $\mathrm{L}$ & $\begin{array}{l}\text { Preventive Maintenance Program } \\
\text { MIC Control Program } \\
\text { Coating Surveillance Program }\end{array}$ & $\begin{array}{l}\text { ISI Program } \\
\text { Maintenance Rule Program } \\
\text { Fuel Oil Tank Program } \\
\text { Underground Storage Tank Program } \\
\text { Technical Specification Surveillance } \\
\text { Program } \\
\text { Operator Activities }\end{array}$ \\
\hline $\begin{array}{c}\text { Carbon Steel } \\
\text { Clean Water }\end{array}$ & $\begin{array}{c}\text { Corrosion } \\
\text { Crevice Pitting }\end{array}$ & $\begin{array}{l}\text { Wall Thinning } \\
\text { Pitting } \\
\text { Cracks }\end{array}$ & $\mathbf{H}$ & $\mathrm{L}$ & $\begin{array}{l}\text { Preventive Maintenance Program } \\
\text { Coating Surveillance Program }\end{array}$ & $\begin{array}{l}\text { ISI Program } \\
\text { Maintenance Rule Program } \\
\text { Technical Specification Surveillance } \\
\text { Program } \\
\text { Operator Activities }\end{array}$ \\
\hline $\begin{array}{l}\text { Carbon Steel/ } \\
\text { Raw Water }\end{array}$ & $\begin{array}{c}\text { Corrosion } \\
\text { Crevice Pitting } \\
\text { MIC }\end{array}$ & $\begin{array}{l}\text { Wall Thinning } \\
\text { Pitting } \\
\text { Cracks }\end{array}$ & $\mathrm{H}$ & $\mathrm{L}$ & $\begin{array}{l}\text { Raw Water Program } \\
\text { Preventive Maintenance Program } \\
\text { MIC Control Program } \\
\text { Coating Surveillance Program }\end{array}$ & $\begin{array}{l}\text { ISI Program } \\
\text { Maintenance Rule Program } \\
\text { Operator Activities }\end{array}$ \\
\hline $\begin{array}{l}\text { Carbon Steel/ } \\
\text { Wet Steam }\end{array}$ & $\begin{array}{c}\text { Corrosion } \\
\text { Two-Phase erosion }\end{array}$ & Wall Thinning & $\mathrm{H}$ & L & $\begin{array}{l}\text { Preventive Maintenance Program } \\
\text { Flow Assisted Corrosion (FAC) } \\
\text { Program }\end{array}$ & $\begin{array}{l}\text { ISI Program } \\
\text { Maintenance Rule Program } \\
\text { Operator Activities }\end{array}$ \\
\hline
\end{tabular}

${ }^{1} \mathrm{H}=\mathrm{High}$

${ }^{2} \mathrm{~L}=$ Low 
AGING MANAGEMENT GUIDELINES FOR TANKS AND POOLS

\begin{tabular}{|c|c|c|c|c|}
\hline Pool Aging Considerations & Aging Mechanism & $\begin{array}{l}\text { Aging } \\
\text { Effect }\end{array}$ & Preventive Programs & Mitigative Programs \\
\hline Liner Corrosion & $\begin{array}{l}\text { Stress Corrosion Cracking } \\
\text { Crevice Pitting } \\
\text { MIC }\end{array}$ & $\begin{array}{l}\text { Cracking } \\
\text { Pitting }\end{array}$ & $\begin{array}{l}\text { Pool Leakage Monitoring Program } \\
\text { Liner Inspection Program }\end{array}$ & $\begin{array}{l}\text { ISI Program } \\
\text { Leak Detection Verification } \\
\text { Operator Activities }\end{array}$ \\
\hline $\begin{array}{l}\text { Steel Embedment/Rebar Corrosion } \\
\text { (Note 1) }\end{array}$ & General Corrosion & Loss of Material & $\begin{array}{l}\text { Periodic Flushing of Leak Detection Box } \\
\text { Coatings Surveillance Program }\end{array}$ & $\begin{array}{l}\text { ISI Program } \\
\text { Leak Detection Verification } \\
\text { Operator Activities }\end{array}$ \\
\hline $\begin{array}{l}\text { Concrete Degradation } \\
\text { (Note 1) }\end{array}$ & Aggressive Chemical Attack & $\begin{array}{l}\text { Spalling } \\
\text { Erosion } \\
\text { Cracking } \\
\end{array}$ & $\begin{array}{l}\text { Epoxy Injection of Cracks } \\
\text { Coatings Surveillance Program }\end{array}$ & $\begin{array}{l}\text { ISI Program } \\
\text { Leak Detection Verification } \\
\text { Operator Activities }\end{array}$ \\
\hline \multicolumn{5}{|c|}{$\begin{array}{l}\text { Note 1: Steel embedment/rebar corrosion and concrete degradation occur primarily as a result of pool liner failure. Steel embedment/rebar corrosion and concrete } \\
\text { degradation are typically characterized as structural aging concerns, but have been presented for completeness. An aging degradation assessment and aging } \\
\text { management program evaluation of Class I structures such as the refueling canal and fuel storage facility can be found in EPRI TR-103842, "Class I Structures } \\
\text { License Renewal Industry Report," Revision 1, dated July } 1994 \text {. }\end{array}$} \\
\hline
\end{tabular}


AGING MANAGEMENT GUIDELINES FOR TANKS AND POOLS

\begin{tabular}{|c|c|c|c|}
\hline Frequency & Activity & Typical Frequency & Remarks \\
\hline \multirow[t]{2}{*}{ Routine } & $\begin{array}{l}\text { Operational monitoring } \\
\text { - visual leakage checks } \\
\text { - gauging (automatic or manual) } \\
\text { - vapor/interstitial monitoring } \\
\end{array}$ & Continuous to weekly & $\begin{array}{l}\text { Safety Class } 2 \text { or } 3 \text { tanks typically have technical specification surveillance } \\
\text { requirements to verify fluid level/boundary integrity. }\end{array}$ \\
\hline & $\begin{array}{l}\text { Cathodic Protection } \\
\text { (impressed current readings) }\end{array}$ & Daily to monthly & Trending and analysis of impressed current readings for changes. \\
\hline \multirow[t]{2}{*}{ Periodic } & Tank tightness & 10 year & $\begin{array}{l}\text { - 10-year visual exam and pressure test per ASME Boiler and Pressure Vessel } \\
\text { Code - Section XI (for Safety Class } 2 \text { or } 3 \text { tanks) } \\
\text { - } 2 \text { to } 10 \text { year for selected UST (e.g., fuel oil) based on State environmental } \\
\text { requirements }\end{array}$ \\
\hline & Coating/liner/surface inspection & $5-10$ year & $\begin{array}{l}\text { For coatings use practical coating lifetime (based on } 5 \text { to } 10 \% \text { breakdown of top } \\
\text { coat). }\end{array}$ \\
\hline \multirow[t]{7}{*}{$\begin{array}{l}\text { One-Time } \\
\text { Evaluations }\end{array}$} & $\begin{array}{l}\text { Materials of construction and fluid } \\
\text { environment }\end{array}$ & Note 1 & $\begin{array}{l}\text { Perform focused one-time inspection based on plausible degradation and associated } \\
\text { aging effects. Take corrective actions based on one-time inspection/analysis. }\end{array}$ \\
\hline & $\begin{array}{l}\text { Interfacing systems, attachments, and } \\
\text { foundations }\end{array}$ & Note 1 & $\begin{array}{l}\text { Perform focused one-time inspection based on plausible degradation and associated } \\
\text { aging effects. Take corrective actions based on one-time inspection/analysis. }\end{array}$ \\
\hline & Margin Evaluation & Note 1 & $\begin{array}{l}\text { Prediction of operational lifetime based on evaluation of degradation rate (e.g., } \\
\text { comosion), materials of construction, and fluid environment. }\end{array}$ \\
\hline & $\begin{array}{l}\text { Experience-based evaluation } \\
\text { (Industry- and plant-specific) }\end{array}$ & Note 1 & Focused inspection/analysis in response to documented industry tank/pool failures. \\
\hline & Coating Lifetime Evaluation & Note 1 & $\begin{array}{l}\text { Determine practical coating lifetime (based on } 5 \text { to } 10 \% \text { breakdown of top coat) or } \\
\text { periodic inspection requirements. }\end{array}$ \\
\hline & Liner lifetime evaluation & Note 1 & Determine liner lifetime or periodic inspection requirements. \\
\hline & $\begin{array}{l}\text { Cathodic protection } \\
\text { (sacrificial anode) }\end{array}$ & Note 1 & Review tank operational history and original sizing analysis. \\
\hline
\end{tabular}


Table 1-7. Framework for Basic Tank System Aging Management Program

Preventive Program (For Corrosion Protection)

$\rightarrow$ Cathodic Protection, or

$\rightarrow$ Interior lining with regular inspection

or

$\rightarrow$ Both

\section{Mitigative Program}

$\rightarrow$ Operational monitoring, either

- $\quad$ Gauging (automatic or manual), or

- Monitoring gaps/tight spaces, or

- Vapor monitoring

or

$\rightarrow$ Inventory Control and tank tightness testing

or

$\rightarrow$ Both

Environmental Concerns (Spill and overflow devices)

\subsection{References}

1.1 Title 10, U.S. Code of Federal Regulations, 10 CFR Part 54, "Requirements for Renewal of Operating Licenses for Nuclear Power Plants," May 8, 1995.

1.2 Title 10, U.S. Code of Federal Regulations, 10 CFR Part 50.65, "Requirements for Monitoring the Effectiveness of Maintenance at Nuclear Power Plants," July 10, 1991. 


\section{INTRODUCTION}

\section{$2.1 \quad$ Background}

The DOE-sponsored Commercial Operating Light Water Reactor Program, in cooperation with EPRI's Life Cycle Management (LCM) Program, is establishing and demonstrating a predictable license renewal process for existing light water reactors (LWRs) in the United States. An important element of this program was the development of Nuclear Management and Resource Council (NUMARC, now the Nuclear Energy Institute, NEI) License Renewal Industry Reports (IRs), which cover critical classes of long-lived passive components such as reactor pressure vessels, reactor coolant pressure boundary piping, containment structures, and cables. To support continued demonstration of plant lifetime improvement and LCM concepts, there is a need for further industry development of guidelines that describe and evaluate acceptable aging management approaches for groupings of equipment not evaluated in the IRs. The DOEsponsored AMGs support that need. To date, seven (7) AMGs have been published:

1) Battery Chargers, Inverters and Uninterruptible Power Supplies[2.1]

2) Batteries, Stationary[2.2]

3) Heat Exchangers[2.3]

4) Motor Control Centers[2.4]

5) Pumps[2.5]

6) Switchgear, Electrical[2.6]

7) Transformers, Power and Distribution[2.7]

In addition, several AMGs are ongoing at this time:

1) Electrical Cables and Terminations (environmentally qualified [EQ] and non-EQ)

2) Containment Penetrations (Electrical and Mechanical)

3) Non-Reactor Coolant Pressure Boundary (RCPB) piping and tubing

4) Tanks and Pools (this AMG)

This AMG evaluates tanks and pools determined to be within the scope of both the License Renewal Rule (LRR), 10 CFR 54.21[2.8], and the Maintenance Rule (MR), 10 CFR 50.65.[2.9]

Continued operation of nuclear power plants for periods that extend beyond the original 40-year license period may be desirable for many U.S. nuclear plant operators. To obtain a renewed license and to operate a plant during a license renewal period, utilities must show that the detrimental effects of aging of components important to license renewal have been managed such that these components will not degrade to the extent that they are incapable of supporting intended function(s). Therefore, operators of nuclear power plants must manage detrimental effects of aging of components so that intended function(s) is assured.

" "Aging Management Guideline for Electrical Cables and Terminations," Sandia National Laboratories Report SAND96-0344, February 1996. 
Components must retain their capability to per. 1 intended function(s) during the license renewal period. Aging management activities such as p-entive maintenance and refurbishment may be necessary during the current license period even though some of these activities may not be necessary to guarantee function during the current license period. These activities would be necessary to have reasonable assurance that there is no loss of intended function(s), no unacceptable reduction in safety margins, and that higher rates of challenge to plant safety systems do not occur during the license renewal period.

\subsection{Purpose and Objectives}

The purpose of this AMG is to provide information on cost-effective, practical methods to plant systems engineers and maintenance personnel for effective aging management of tanks and pools used in commercial nuclear power plants. Many of the same methods can be used to provide effective aging management of similar equipment in fossil fuel power plants. An effective aging management program will provide reasonable assurance that each above- or below-ground tank or pool will continue to perform its intended function(s) or will not prevent performance of an intended function(s) during the current license period and the license renewal term.

The objectives of this AMG are to provide an analysis of the potential degradation modes, including the effects of aging, for tanks and pools and to provide acceptable guidelines for effective aging management programs that will provide reasonable assurance that intended function(s) will be preserved.

This AMG is intended for nuclear plant personnel performing tank and pool aging management evaluations and maintenace activities and provides information and guidance that will be valuable in the formulation of the plant's aging management programs. This AMG also provides additional value to nuclear plant operators as follows:

1. The AMG is a well-researched technical document that can be used by maintenance and system engineering personnel for the identification, characterization, and management of age-related degradation in tanks and pools. It can also be used as a reference document for plants developing a license renewal application and/or demonstrating compliance with the MR.

2. The information presented is based on an extensive literature search. Therefore, nuclear plant personnel can use this AMG as a resource document for relevant information about tanks and pools. Some of the references used include:

- EPRI Reports

- NRC Bulletins, Information Notices, Circulars, Generic Letters and Reports

- Code of Federal Regulations (CFR)

- Vendor Drawings and Manuals

- Industry Codes and Standards

- Miscellaneous References and Technical Papers 
3. This AMG consolidates historical maintenance and industry operating information into one source. The plant maintenance/system engineer will find this useful for both the identification of age-related degradation (including root causes) and the verification of appropriate corrective actions. Issues discussed include:

- Operating and maintenance history from the Institute for Nuclear Power Operations (INPO) Nuclear Plant Reliability Data System (NPRDS) and NRC Licensee Event Report (LER) databases

- Additional operating and maintenance history from responses to plant surveys and input from host utilities

- Equipment design differences relevant to aging considerations

- Equipment obsolescence (replacement of equipment) as it affects aging management

- Service environments

4. Aging phenomena are described in detail. This will be useful for tanks and pools maintenance interval and reliability evaluations. The following topics are discussed:

- Stressors acting on tanks/pools

- Aging mechanism identification

- Significance of aging mechanisms using "if/then" criteria

- Age-related degradation and potential failure modes

- Effects of aging

5. The AMG can be an effective tool for aging management and personnel training because it:

- Identifies the need for aging management and can be used as input for Maintenance Rule performance measures and corrective action requirements

- Discusses both conventional and non-conventional maintenance techniques, and considers how these practices can be utilized to effectively manage equipment aging

- Characterizes initiation and progression of equipment aging for use in training personnel responsible for maintenance and inspection activities

- Identifies concepts, principles, and methods for evaluating tanks and pools not in the scope of this AMG.

\subsection{Contents of Aging Management Guideline}

This AMG evaluates tanks and pools determined to be within the scope of both the LRR, 10 CFR 54.21, and the MR, 10 CFR 50.65. Sources of information were previous BWR and PWR Lead Plant License Renewal studies, piping and instrumentation diagrams (P\&IDs), NUMARC 93-02 Maintenance Rule verification and validation results,[2.10] and draft NUREG-1299 [2.11]. Tanks and pools that are unique with respect to manufacturer/models, or are used in only one or very few plants (for example, boration makeup systems in plants that have to plan for a large water dam break) were not evaluated in this AMG. Maintenance Rule verification and validation efforts and BWR/PWR Lead Plant License Renewal studies relied on 
a screening process to identify and select specific system tanks and pools that need to be evaluated. The screening process uses a systematic approach to identify tanks and pools with important-to-safety operating functions or that may initiate or challenge safety systems.

Section 3 provides the results of the screening for the AMG, lists the tanks and pools evaluated and component boundaries. Section 3 also includes a detailed study of the operating history of the tanks and pools evaluated from LER data, NPRDS data, and from other sources.

Section 4 discusses stressors, aging mechanisms, age-related degradation, failure modes, and the effects of aging acting on tanks and pools. Stressors produce aging mechanisms that can cause component degradation. An aging mechanism effect is significant when, if allowed to continue without detection or mitigation measures, it will cause the component to lose its ability to perform its intended function(s). Potentially significant and non-significant aging mechanisms/effects relevant to tanks and pools are identified and evaluated. Operational demands, environmental conditions, failure data, industry operations, and maintenance history are considered, and the significance of the aging mechanisms determined. The entire set of aging mechanisms evaluated in this AMG is provided in Section 4.

Section 5 discusses aging management techniques that can be used to mitigate aging mechanisms determined to be potentially significant in Section 4. Conventional and unconventional maintenance, inspection, testing, and surveillance techniques or programs are described. The effectiveness of these techniques or programs to manage significant aging mechanisms/effects is described wherever supported by historical operating data. Variations in plant aging management programs or techniques are discussed. Requirements for an effective technique or program are presented in the form of "if/then" criteria whenever possible.

Section 6 discusses other aging management considerations, if applicable, to address potentially unresolved issues identified in Section 5. Appendix A provides a list of definitions for aging terminology based on Reference 2.12. Appendix B provides a list of acronyms. Appendix $\mathrm{C}$ includes a discussion of the design requirements that apply to tanks, including applicable industry codes, standards, and regulations. Appendix D includes survey forms used to gather utility specific data on tanks and pools. Appendix E includes non-significant aging mechanism descriptions.

\subsection{Generic License Renewal Requirements}

10 CFR 54.21[2.8, 2.13] describes the requirements for the content of technical information in a license renewal application. Section 54.21 states that an application for license renewal must contain the following:

1. An Integrated Plant Assessment (IPA),

2. Current Licensing Basis (CLB) changes during NRC application review of the application,

3. An evaluation of time-limited aging analyses (TLAA) and exemptions,

4. A Final Safety Analysis Report (FSAR) supplement. 
An IPA must:

1. For those systems, structures and components within the scope, as delineated in 10 CFR Part 54.4, identify and list those structures and components subject to aging management review,

2. Describe and justify the methods used in item 1 (scope determination) of the IPA, and

3. For each structure and component identified in item 1 of the IPA, demonstrate that the effects of aging will be adequately managed so there is reasonable assurance that the intended function(s) will be maintained consistent with the CLB for the period of extended operation.

An aging management review is intended to demonstrate that plant "programs and procedures will provide reasonable assurance that the functionality of systems, structures and components requiring review will be maintained during the period of extended operation. " [2.8] The LRR focuses on the effects of aging rather than a detailed review of aging mechanisms. The LRR states there must be a "reasonable assurance" that intended function(s) of systems, structures, and components (SSCs) will be maintained.

This AMG evaluates all potentially significant aging mechanisms and aging management practices that can be used to demonstrate that the effects of aging will be managed so that the intended function(s) will be maintained, even though the LRR does not require this level of detail. It also discusses the link between aging mechanisms and the effects of aging.

Exemptions (pursuant to 10 CFR 50.12) were not considered under this AMG in that these issues are plant-specific in nature and therefore must be considered on a plant-by-plant basis.

\subsection{Method(s) Used to Define the Scope of Components to be Evaluated Under the License Renewal Rule (LRR) and the Maintenance Rule (MR)}

To determine the tanks and pools covered by LRR and MR requirements, the definitions of SSCs within the scope of the LRR and MR must be evaluated. Table 2-1 describes and compares the current definitions.

Note that the scope of tanks and pools covered under the Maintenance Rule, 10 CFR 50.65,[2.9] is almost the same as that covered by the License Renewal Rule, 10 CFR 54.21.[2.8] 
Table 2-1. License Renewal Rule and Maintenance Rule Scope Screening Requirements

\begin{tabular}{|c|c|}
\hline License Renewal Rule & Maintenance Rule \\
\hline Safety-Related SSCs & Safety-Related SSCs \\
\hline $\begin{array}{l}\text { 1. Safety-related SSCs, which are those relied } \\
\text { upon to remain functional during and } \\
\text { following design-basis events to ensure: }\end{array}$ & 1. Same as for LRR. \\
\hline $\begin{array}{l}\text { a. The integrity of the reactor coolant } \\
\text { pressure boundary, }\end{array}$ & a. Same as for LRR. \\
\hline $\begin{array}{l}\text { b. The capability to shut down the reactor } \\
\text { and maintain it in a safe shutdown } \\
\text { condition, or }\end{array}$ & b. Same as for LRR. \\
\hline $\begin{array}{l}\text { c. The capability to prevent or mitigate the } \\
\text { consequences of accidents that could } \\
\text { result in potential off-site exposure } \\
\text { comparable to the } 10 \text { CFR } 100 \text { guidelines. }\end{array}$ & c. Same as for LRR. \\
\hline Non-Safety-Related SSCs & Non-Safety-Related SSCs \\
\hline $\begin{array}{l}\text { 2. All non-safety-related SSCs whose failure } \\
\text { could directly prevent satisfactory } \\
\text { accomplishment of any of the intended } \\
\text { function(s) identified in paragraphs (1) (a), } \\
\text { (b), or (c) of this definition. }\end{array}$ & $\begin{array}{l}\text { 2. a. Whose failure could prevent safety-related } \\
\text { structures, systems, and components from } \\
\text { fulfilling their safety-related function, }\end{array}$ \\
\hline & $\begin{array}{l}\text { b. That are relied upon to mitigate accidents } \\
\text { or transients or are used in plant } \\
\text { emergency operating procedures (EOPs), }\end{array}$ \\
\hline & $\begin{array}{l}\text { c. Whose failure could cause a reactor } \\
\text { scram or actuation of a safety-related } \\
\text { system. }\end{array}$ \\
\hline Regulatory Required & Regulatory Required \\
\hline $\begin{array}{l}\text { 3. All SSCs relied on in safety analyses or plant } \\
\text { evaluations to demonstrate compliance with } \\
\text { the Commission's regulations for: }\end{array}$ & \\
\hline - $\quad$ Fire Protection (10 CFR 50.48) & \\
\hline $\begin{array}{l}\text { Environmental Qualification } \\
\text { (10 CFR 50.49) } \\
\end{array}$ & \\
\hline 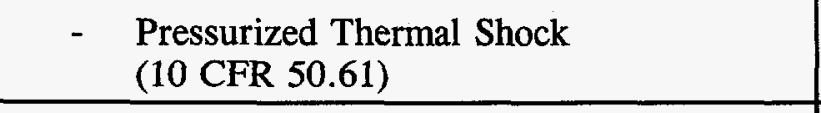 & \\
\hline $\begin{array}{l}\text { - Anticipated Transients without Scram (10 } \\
\text { CFR 50.62) }\end{array}$ & \\
\hline - $\quad$ Station Blackout (10 CFR 50.63) & \\
\hline
\end{tabular}




\subsection{Method(s) Used to Define Aging Mechanisms Assessed in This Study}

As indicated above, the revised LRR does not require explicit evaluation of aging mechanisms, but does require the reasonable assurance of preserving intended function(s) that may be degraded due to the effects of aging. Because the intended end users of this AMG consist of systems engineers and plant maintenance personnel, it was decided that it would be beneficial to include a detailed description of stressors, aging mechanisms, and failure modes as well as the effects of aging. This approach was supported by feedback from users of published AMGs.

To define aging mechanisms assessed in this study, a two-part evaluation was performed. First, the effects of stressors (e.g., mechanical, hydraulic, chemical, electrical and environmental) on equipment operation are determined. Then, aging mechanisms associated with those stressors are defined. Finally, age-related degradation mechanisms and failure modes caused by aging mechanisms are described. This evaluation is contained in Section 4 .

Second, industry-wide operating experience (particularly that reported in NRC LERs; Information Notices, Bulletins, and Circulars; and INPO NPRDS data) was examined. A review of the NRC Information Notices, Bulletins, and Circulars was conducted to identify age-related failures. Events described in the NPRDS data and LERs were then analyzed for age-related degradation and to identify the numbers of particular types of failures. The aging mechanisms associated with these failures were then determined. The review of industry-wide operating experience is contained in Section 3.4.

This multi-source analysis (i.e., using data from NPRDS and NRC documentation) provides a comprehensive characterization of equipment aging by using actual plant and vendor data to substantiate and refine those aging mechanisms that occur due to postulated stressors.

After a list of all possible aging mechanisms was developed (see Section 4), the significance of each aging mechanism was determined. Those aging mechanisms that were confirmed by operating or overhaul experience, had a high probability of occurrence, or would result in a failure having a large impact on equipment operation were designated as significant. Those aging mechanisms designated as significant are discussed in Section 4.3.1; those aging mechanisms designated non-significant are briefly discussed in Section 4.3.2 and in more detail in Appendix E.

Conventional maintenance, inspection, testing, and surveillance techniques or programs determined to effectively manage aging of tanks and pools are discussed in Section 5.2. A brief discussion of nonconventional activities and techniques is provided in Section 5.3. The aging management techniques and programs that effectively manage the significant aging mechanisms are discussed in Section 5.4.

\subsection{References}

2.1 "Aging Management Guideline for Commercial Nuclear Power Plants - Battery Chargers, Inverters and Uninterruptible Power Supplies," Sandia National Laboratories report SAND93-7046, February 1994. 
2.2 "Aging Management Guideline for C Batteries, " Sandia National Laborat

nercial Nuclear Power Plants - Stationary ; report SAND93-7071, March 1994.

2.3 "Aging Management Guideline for mmercial Nuclear Power Plants - Heat Exchangers," Sandia National Labor ries report SAND93-7070, June 1994.

2.4 "Aging Management Guideline for ummercial Nuclear Power Plants - Motor Control Centers," Sandia National Laboratories report SAND93-7069, February 1994.

2.5 "Aging Management Guideline for Commercial Nuclear Power Plants - Pumps," Sandia National Laboratories report SAND93-7045, March 1994.

2.6 "Aging Management Guideline for Commercial Nuclear Power Plants Switchgear, Electrical," Sandia National Laboratories report SAND93-7027, July 1993.

2.7 "Aging Management Guideline for Commercial Nuclear Power Plants Transformers, Power and Distribution," Sandia National Laboratories report SAND93-7068, May 1994.

2.8 Title 10, U.S. Code of Federal Regulations, 10 CFR Part 54, "Requirements for Renewal of Operating Licenses for Nuclear Power Plants," May 1995. [See Federal Register, Vol. 60, No. 88, Monday, May 8, 1995, Rules and Regulations, pp. 22461-22495.]

2.9 Title 10, U.S. Code of Federal Regulations, "Requirements for Monitoring the Effectiveness of Maintenance at Nuclear Power Plants," 10 CFR Part 50.65, July $10,1991$.

2.10 NUMARC 93-02, "A Report on the Verification and Validation of NUMARC 93-01, Draft Revision 2A, "Industry Guideline for Monitoring the Effectiveness of Maintenance at Nuclear Power Plants, " May 1993.

2.11 Draft NUREG-1299, "Standard Review Plan for the Review of License Renewal Applications for Nuclear Power Plants," November 1990.

2.12 EPRI Report TR-100844, "Nuclear Power Plant Common Aging Terminology," November 1992.

2.13 "Guidelines to Implement the License Renewal Technical Requirements of 10CFR54 For Integrated Plant Assessments and Time-Limited Aging Analyses," EPRI report TR-105090, draft final report, Appendices A through E, June 1995. 


\section{EQUIPMENT EVALUATED}

\subsection{Results of Methodology Used to Select Components Within the Scope of the License Renewal and Maintenance Rules}

The process utilized to screen and group the equipment included in the AMG consisted of 1) identifying the applicable systems, 2) reviewing the systems to identify the applicable tanks/pools, and 3) grouping the selected tanks/pools using important design and operating parameters.

\subsubsection{Screening Process}

The screening process generated a set of representative tank/pool groups for a detailed aging management review. An initial population of tanks/pools was developed using screening from ongoing industry activities related to the Maintenance Rule and License Renewal Rule. The initial list was supplemented by a careful study of various Final Safety Analysis Reports (FSARs) and P\&IDs to ensure no tanks in the scope of this AMG were inadvertently left out. This was accomplished through the use of existing plant screening information and reviews conducted by host utilities. The screening methodology consisted of:

- Identifying important systems.

- Identifying tanks within important systems.

- Determining which tanks were not safety-related.

- Applying engineering judgement with independent review of plant-specific applications.

\subsubsection{Identification of Tanks/Pools Within Scope of AMG}

Several sources of information supported implementation of this methodology. These sources were gathered and reviewed in detail to identify the scope of tanks/pools to be evaluated.

The identification of AMG tanks/pools began with work already completed by NUMARC in the verification and validation of maintenance rule implementation efforts. NUMARC 93-02 [3.1] contains nuclear steam supply system (NSSS) vendor-specific lists of systems that have been screened as within the scope of the Maintenance Rule (10 CFR 50.65). Due to the broad similarity in the criteria that establish the scope of the Maintenance Rule and License Renewal Rule (10 CFR 54) (see Table 2-1), these system lists served as the starting point. Several nuclear utilities have completed system-level screening based solely upon the license renewal rule scope. These results were referenced to build upon the Maintenance Rule system lists for each NSSS vendor. Specific sources of license renewal screening information were as follows:

- Yankee Rowe PWR Lead Plant System Level Screening

- Monticello BWR Lead Plant System Level Screening

- BG\&E System Level License Renewal Screening

- Westinghouse Owners Group (WOG) System Level Screening

- B\&W Owners Group (BWOG) System Level Screening Results

- BWR Owners Group (BWROG) System Level Screening Results 
The review of all applicable screening results provided a set of NSSS vendor-specific lists of systems that are within the scope of the Maintenance Rule and License Renewal Rule.

The tanks/pools identification process was finalized by using simplified schematics available from the INPO NPRDS user manuals for each NSSS vendor plant type and various FSAR P\&IDs. Tanks within important systems were identified as within the scope of this AMG if they met one or more of the following criteria:

- Performs safety-related function(s) (i.e., within safety-related boundary)

- Performs non-safety-related and/or regulatory required function(s) as defined in Table 3-1

- Experiences maximum pressures only slightly above atmospheric (i.e., not a pressure vessel)

- Has broad applicability to several plant designs (i.e., generic application)

\subsection{Listing of Components Evaluated}

\subsubsection{Evaluation Scope}

The tank/pool selection methodology described in Section 3.1 was used to establish the listing of BWR and PWR tanks/pools in Table 3-1. The following general tank/pool categories are evaluated in this AMG:

Tanks - Atmospheric

American Society of Mechanical Engineers (ASME) design rules for atmospheric storage tanks address vertical, cylindrical, flat-bottom, above-ground, welded tanks at atmospheric pressure. Typical applications include those where the tanks contain liquids such as refueling water, condensate, borated reactor coolant, or liquid radioactive waste. Such tanks may be within building structures, depending upon the liquid to be contained, or they may be above grade exposed to atmospheric conditions. These rules do not limit storage tanks from being installed below grade or below ground, provided the tanks are not subject to external pressure resulting from earth or fill.[3.2] An additional discussion regarding tanks can be found in Section 3.4.2.5.

Tanks - 0 to 15 psi

ASME design rules for 0 to 15 psi storage tanks address above-ground, welded storage tanks at a pressure slightly above atmospheric pressure. Typical applications include those where the tanks contain liquids or gases such as refueling water, condensate, borated reactor coolant, or radioactive waste. These tanks are normally located within building structures because of their pressurized condition.[3.3] 


\begin{tabular}{|c|c|}
\hline BWR Tanks/Pools & PWR Tanks/Pools \\
\hline $\begin{array}{l}\text { TANKS } \\
\text { - Condensate Storage Tank (clean) (1) } \\
\text { - Condensate Storage Tank (contaminated) } \\
\text { - Diesel Fuel Storage Tank } \\
\text { - Diesel Fuel Day Tank } \\
\text { - Fire Water Storage Tank } \\
\text { - Fuel Pool Skimmer Surge Tank } \\
\text { - Fuel Pool Drain Tank }{ }^{(1)} \\
\text { - High-Pressure Core Spray Floor Pit/Tank } \\
\text { - Reactor Building Closed Cooling Water } \\
\text { Tank } \\
\text { - Standby Liquid Storage Tank }\end{array}$ & $\begin{array}{l}\text { TANKS } \\
\text { - Condensate Storage Tank } \\
\text { - Diesel Fuel Storage Tank } \\
\text { - Diesel Fuel Day Tank } \\
\text { - Fire Water Storage Tank } \\
\text { - Boric Acid Tanks } \\
\text { - Demineralized Water Tank (1) } \\
\text { - Containment Spray Additive Tank } \\
\text { - Refueling Water Storage Tank }{ }^{(2)} \\
\text { - Component Cooling Water System Surge } \\
\text { Tank } \\
\text { - Volume Control Tank }{ }^{(4)} \\
\text { - Isolation Valve Seal Water Tank }\end{array}$ \\
\hline $\begin{array}{l}\text { POOLS } \\
\text { Spent Fuel Pool }\end{array}$ & $\begin{array}{l}\text { POOLS } \\
\text { Spent Fuel Pool }{ }^{(3)}\end{array}$ \\
\hline
\end{tabular}

\section{Notes:}

(1) Included for completeness (pressure vessel or non-safety tank)

(2) Includes Containment Spray Storage Tanks (CE design) and Borated Water Storage Tanks (B\&W design)

(3) Includes Fuel Holding Pool, Transfer Canal, Refueling Cavity, and Upper Containment Fuel Storage Pool

(4) Called a Makeup Water Tank in B\&W designed plants

Pools

Spent fuel storage pools are designed to store and protect fuel to assure the capability to prevent or mitigate the consequences of plant conditions that could result in potential off-site exposures that are a significant fraction of the 10 CFR 100 limits. These pools are designed to attain the following:[3.4]

- Prevent criticality,

- Remove decay heat, and

- Prevent fuel damage. 
Subcriticality is ensured by the geometric design features of the spent fuel storage racks. A pool water cooling system is used to remove decay heat from the pool. If the pool water reaches an elevated temperature (e.g., boiling), there may be a slight increase in release of radioactivity. The pool water cleanup system minimizes dissolved and suspended radioactive material from the pool.[3.5]

The typical spent fuel storage pool components consist of concrete pool structures, stainless steel pool liners, isolation valves and gates.[3.4]

\subsubsection{Exclusions from Scope}

Some tank/pool applications were specifically excluded from the scope of this AMG. The bases for these exclusions are provided in the discussions below.

Pressure Vessels

Pressure vessels are defined in ASME Section VIII as "containers for the containment of pressure, either internal or external. This pressure may be obtained from an external source or by the application of heat from a direct on indirect source, or any combination thereof." Since the purpose of this AMG was to address aging management for atmospheric and low pressure tank applications, pressure vessels are not part of the scope. Examples of vessels excluded from the scope are as follows:

- Accumulators

- Receivers

- Some surge tanks (some are included-Reactor Building Closed Cooling Water (RBCCW) and PWR Component Cooling System Tanks are surge tanks)

- Reactor pressure vessel

Furthermore, pressure vessels have been evaluated extensively in other industry studies. Specific examples of pressure vessel studies are included in References 3.6, 3.7, 3.8, and 3.9 .

Unique Applications

The intent of this guideline is to capture all tanks/pools common to most BWR and PWR plants, but not necessarily all low-pressure or vented tanks/pools that are unique to a limited number of plants. Therefore, unique tank applications that have limited applicability to BWR and/or PWR plants were excluded from the scope.

BWR Suppression Pools

BWR suppression pools provide a heat sink for the suppression of post-accident high energy releases inside containment to limit the resulting containment pressure surge. Due to the nature of the function of these pools and their relation to the containment structure, they have been excluded from the scope of this AMG. Discussion of BWR suppression pools may be found in Reference 3.10 . 
Radioactive Waste Tanks

Regulatory Guide 1.143, "Design Guidance for Radioactive Waste Management Systems, Structures, and Components Installed in Light-Water-Cooled Nuclear Plants, Revision 1," applies to tanks that are in radioactive waste treatment systems such as waste liquid, waste gas, and boron recycle. [3.11] Regulatory Guide 1.143 provides guidance in declassifying safetyrelated components in waste management systems that were classified as safety-related on the sole basis that they contained radioactive effluents. Therefore, these tanks have been excluded from the scope of this AMG.

\subsubsection{Tank/Pool Grouping}

Based on a review of the applicable information, the tanks/pools can be categorized into five different groups:

(1) Tanks containing clean water

(2) Tanks containing diesel fuel oil

(3) Tanks containing chemicals

(4) Tanks containing dirty/raw/waste fluid

(5) Pools (spent fuel pool) containing water

Tanks containing clean water are found in many plant systems. Minor amounts of chemical additives are present in the water, but are not in such concentration as to cause degradation. Examples of such components are the condensate storage tank, component cooling water tank, and the demineralized water storage tank.

Tanks containing diesel fuel oil or petroleum-based products are found mainly in the Emergency Diesel Generator System. This category includes both buried and above-ground tanks.

Tanks containing chemicals are found mainly in the systems for bulk chemical storage for water treatment, condensate, cooling water, or containment spray. These tanks are usually protected with liners and special coatings to prevent corrosion. An example of such a tank is the containment spray additive tank.

Tanks containing other miscellaneous fluids/materials capture all other tanks that do not fit into any of the categories discussed above (mostly waste, raw water, or special applications).

Pools consist of the wetted pools that are required for the storage of spent fuel or for the safe transfer of the spent fuel from the reactor vessel to the spent fuel pool. These pools include the reactor cavity pool, refueling canal, spent fuel pool, etc.

\subsection{Component Boundaries}

For tanks, the boundaries of the evaluation are defined by the tank and its nozzles for piping attachments. This AMG covers the shell, connecting nozzles, internal standpipes and other internal components (e.g., bladders, diaphragms) saddles/supports, and manways. Piping, 
valves (including float control valves), or similar components attached to the tank are not evaluated in this report since they are more directly related to the piping system connected to the tank. Also included within the component boundary are the supports for the tank. However, concrete bases are not included in the scope (see Reference 3.12).

For spent fuel pools, the boundary of the evaluation is defined by the liner, liner leak chase system, and liner attachments. Piping, nozzles, instruments, or similar components are not evaluated in this report since they are more directly related to the spent fuel storage and cooling system.

Illustrations of two typical tank arrangements and a typical spent fuel pool arrangement are provided as Figures 3-1 through 3-3.

\subsection{Operating and Service History}

A review of industry data and documents was conducted to determine the operating experience of the tanks/pools evaluated in this AMG. The types of documents reviewed were:

- INPO NPRDS database

- NRC LER database

- Host utility data and individual plant survey data

- INPO Technical Library Database

- Other industry data

A summary of the reviews of each of the above documents is discussed in this section. Section 3.4.1 contains the review process, and Section 3.4.2 summarizes the review results.

Plant operating and service data were collected from utilities in response to a questionnaire on tank/pool types, design parameters, and maintenance history. The tanks/pools failure/degradation identified in these responses is enveloped under the aging mechanisms identified in the LER and NPRDS information. For this reason, the LER and NPRDS discussions collectively address plant operating experiences, and a separate discussion of utility questionnaire responses is not necessary.

\subsubsection{Industry-Wide Operating Experience of Components}

\subsubsection{INPO NPRDS Database}

The NPRDS was developed in 1973 to collect data on safety-related equipment. Since then, the NPRDS scope has been expanded to include other systems and components that provide critical safety functions and whose loss of function can initiate a significant transient. Utilities submit component failure records whenever an NPRDS-reportable component fails to perform one or more of its intended functions. Reporting failures is a voluntary industry effort and, therefore, there are many variations in interpretation of reportability requirements and contents and consistency of reports. Per INPO-89-014, United States nuclear utilities have demonstrated 

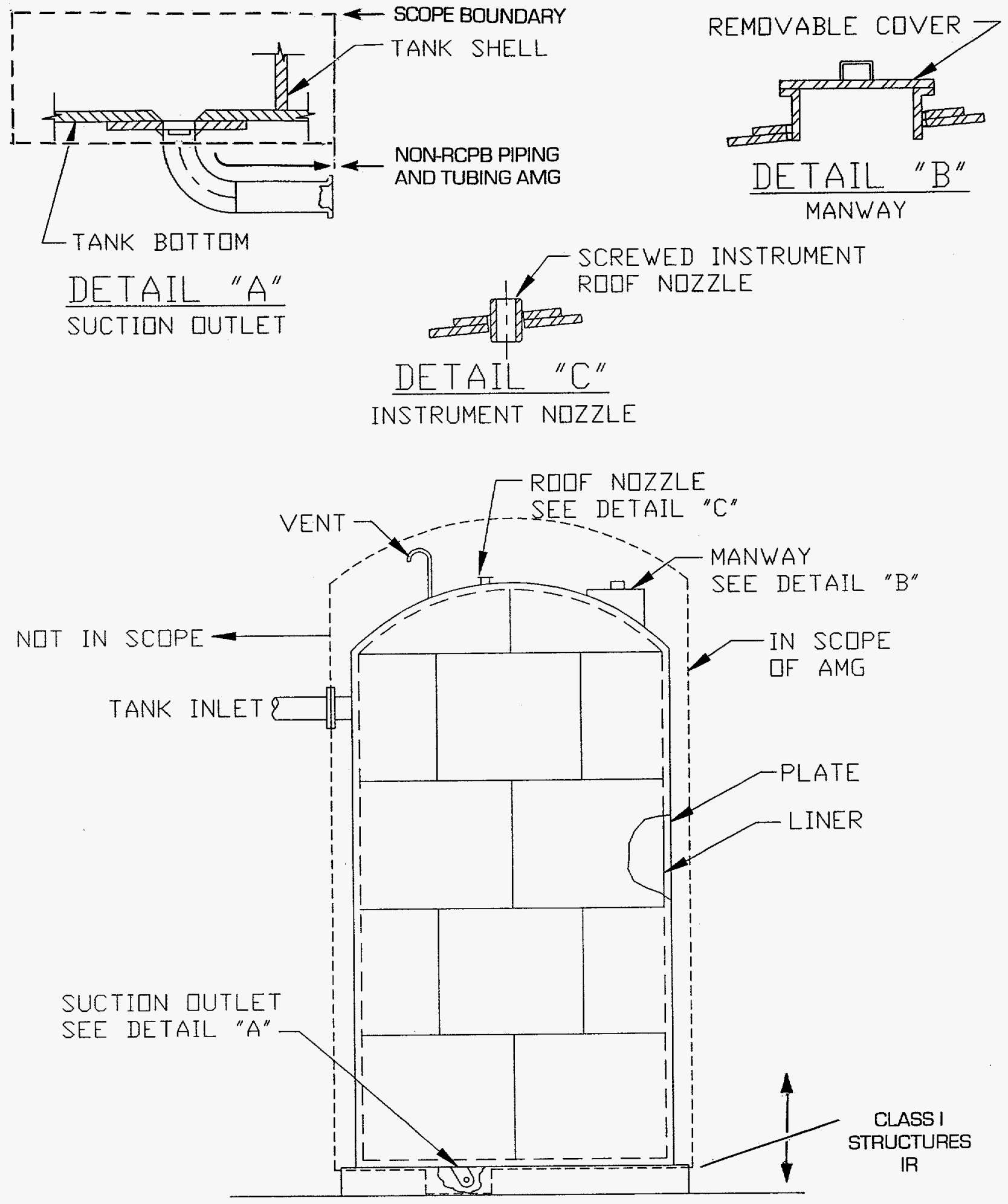

Figure 3-1. Typical Vertical Free-Standing Tank. 

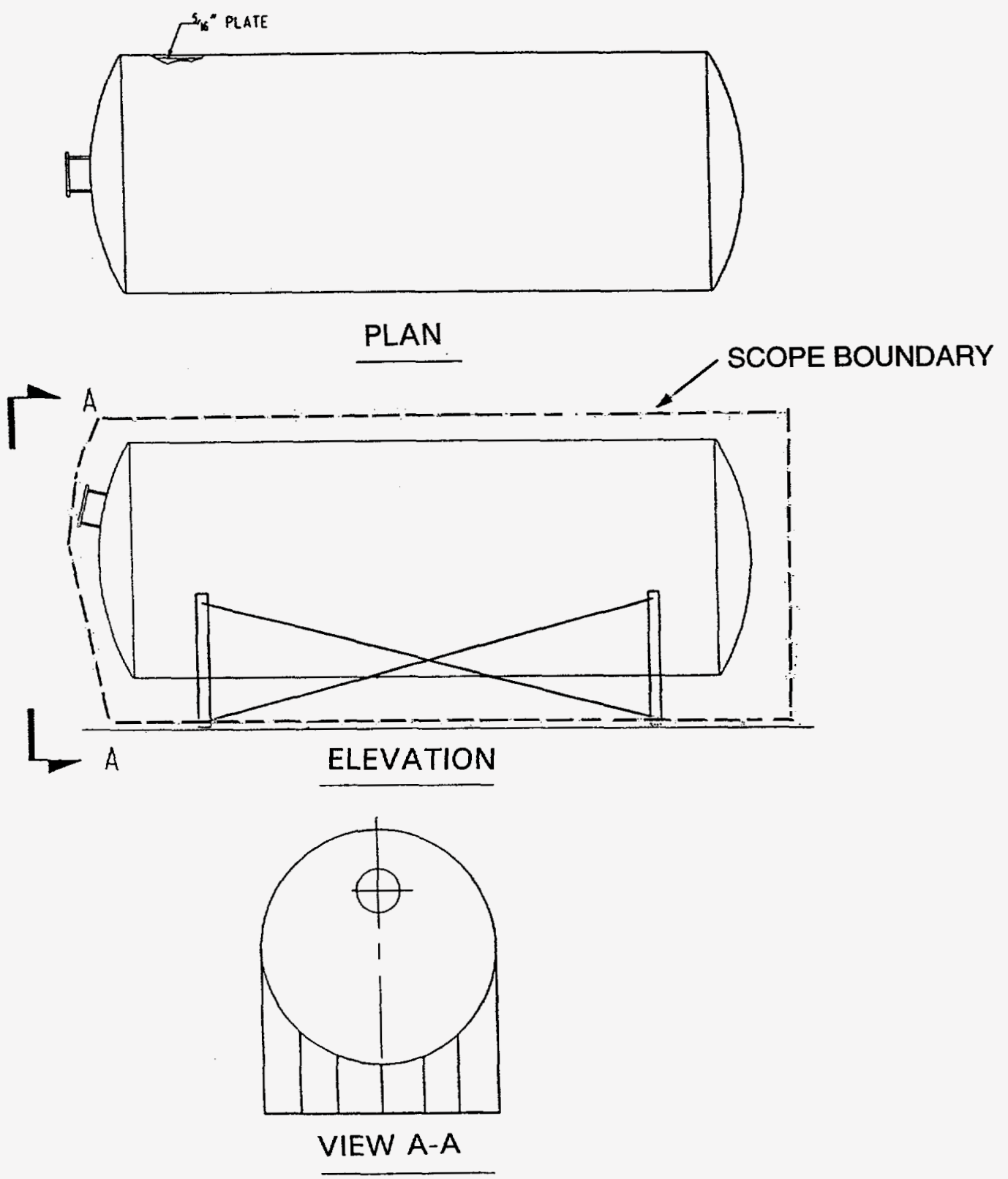

HORIZONTAL SUPPORTED TANK

Figure 3-2. Typical Horizontal (Supported) Tank. 


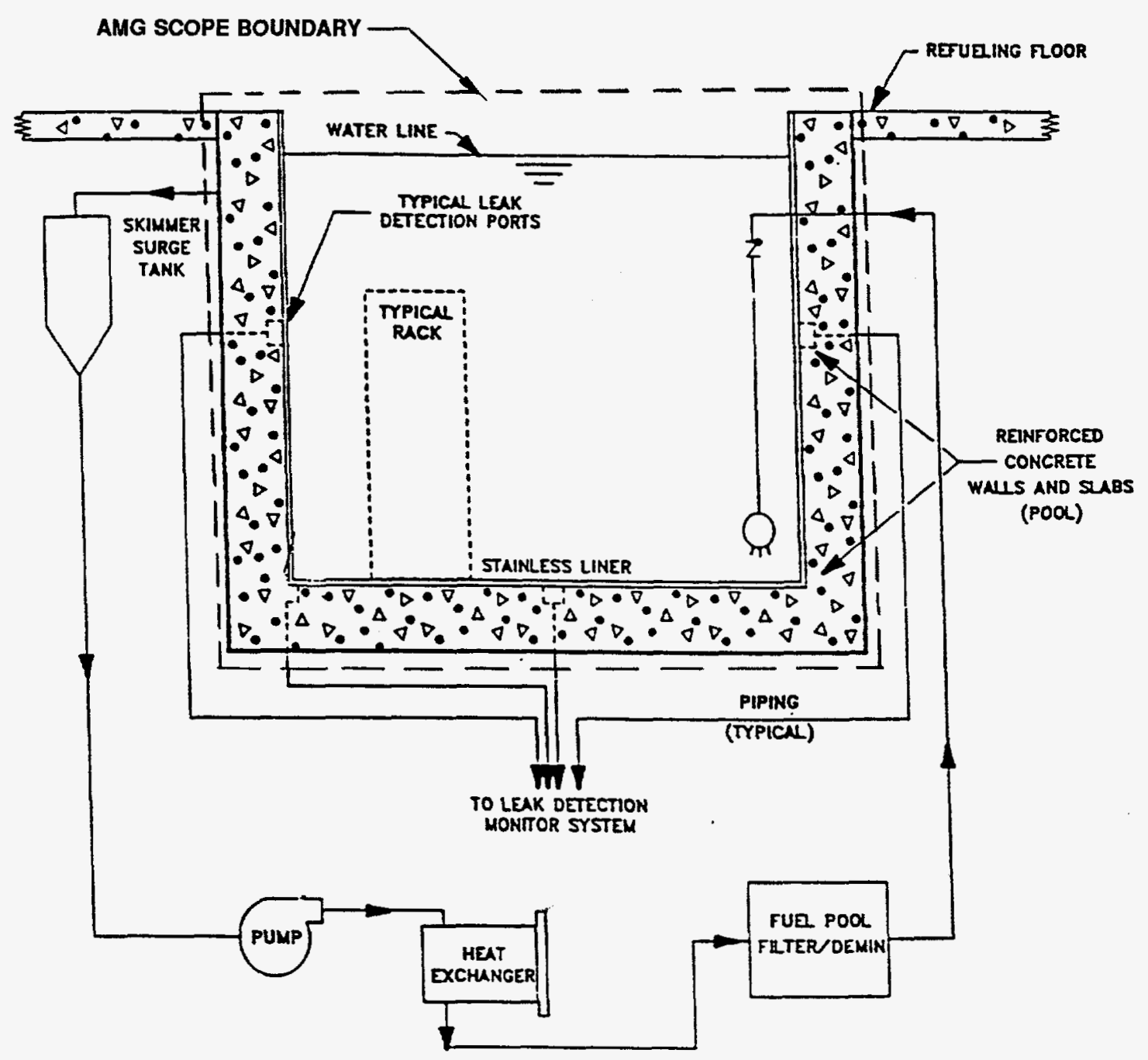

Figure 3-3. Typical BWR Spent Fuel Pool at Plants with Mark I or II Containments. 
their support of NPRDS by dedicating resources to record all reportable failures that have occurred since January 1, 1984, or when the plant begins commercial operation. Previously, the LER was widely used for reporting failures.

A keyword search of the NPRDS database was performed to determine the type and quantity of tanks/pools. NPRDS does not characterize equipment in its database as being a "tank"; instead it uses the word "accumulator" to describe tanks, pressure vessels, receivers, reservoirs, and other similar "storage components." A manual search of the NPRDS printout was necessary to determine which "accumulators" were actually "tanks" since the scope of this AMG does not include pressurized vessels. Systems which contain tanks or pools evaluated in this AMG are listed in Table 3-2.

A keyword search of "accumulator" failures/degradation was performed on the NPRDS database for the period from December 1976 to September 1993.[3.13] A two-step review of the abstracts was performed to segregate those tanks/pools included in the scope of this AMG and then to further segregate where aging was identified as the primary cause of the tank/pool failure/degradation.

The two-step manual screening process reduced the data by excluding those records having situations where:

- The primary cause of the tank/pool failure was non-age-related (e.g., design error, procedure deficiency, inadequate or improperly performed maintenance, personnel error, etc.).

- The vessel is not classified as a tank/pool in the scope of this AMG (e.g., reactor vessel, containment vessel, pressure vessels, etc.).

- The tank/pool failure was caused by the aging failure/degradation of a supporting piece of equipment (e.g., control valve, instrumentation, piping, etc.).

- The tank/pool identified in the database was a boiler or reactor pressure vessel. Degradation of both of these components is evaluated extensively in other industryrelated documentation.

- The tank/pool failure was due to gasket failure. [Gaskets are renewable items and should be replaced at regularly scheduled intervals.] 


\begin{tabular}{|c|c|c|}
\hline System & NSSS Designer & Tank or Pool Evaluated in AMG \\
\hline Chemical \& volume control & BW, CE, WEC & $\begin{array}{l}\text { Boric acid tank, volume control tank (called makeup } \\
\text { tank in B\&W plants) }\end{array}$ \\
\hline Component cooling water & $\mathrm{BW}, \mathrm{CE}, \mathrm{WEC}$ & Component cooling water surge tank \\
\hline Condensate & BW, CE, GE, WEC & Condensate storage tank (clean and contaminated) \\
\hline Containment spray & GE & Condensate storage tank \\
\hline $\begin{array}{l}\text { Containment spray/reactor } \\
\text { building spray }\end{array}$ & BW, CE, WEC & $\begin{array}{l}\text { Containment spray storage tank (CE), spray additive } \\
\text { tank (BW, CE, WEC), refueling water storage tank } \\
\text { (CE, WEC), and borated water storage tank (BW) }\end{array}$ \\
\hline Demineralized water & $\mathrm{BW}, \mathrm{CE}, \mathrm{WEC}$ & $\begin{array}{l}\text { Demineralized water storage tank (also called the } \\
\text { reactor makeup water tank) }\end{array}$ \\
\hline Diesel fuel oil & BW, CE, GE, WEC & Diesel fuel day and storage tanks \\
\hline $\begin{array}{l}\text { Feedwater/emergency } \\
\text { feedwater }\end{array}$ & $\mathrm{BW}, \mathrm{CE}, \mathrm{GE}, \mathrm{WEC}$ & Condensate storage and fire water storage tanks \\
\hline Fire protection & BW, CE, GE, WEC & Fire water storage tank \\
\hline $\begin{array}{l}\text { High pressure and low } \\
\text { pressure injection }\end{array}$ & BW & Borated water storage tank \\
\hline High pressure safety injection & CE, WEC & Refueling water storage tank \\
\hline $\begin{array}{l}\text { High pressure coolant injection } \\
\text { and low pressure safety } \\
\text { injection }\end{array}$ & GE & Condensate storage tank \\
\hline High pressure core spray & GE & Condensate storage and floor/pit tank \\
\hline Isolation valve seal water & WEC & Isolation valve seal water tank \\
\hline Reactor core isolation cooling & GE & Condensate storage tank \\
\hline $\begin{array}{l}\text { Reactor building closed } \\
\text { cooling water (RBCCW) }\end{array}$ & GE & RBCCW tank \\
\hline $\begin{array}{l}\text { Residual heat removal/low } \\
\text { pressure safety injection }\end{array}$ & $\mathrm{BW}, \mathrm{CE}, \mathrm{WEC}$ & Refueling water storage tank \\
\hline Spent fuel & $\mathrm{BW}, \mathrm{CE}, \mathrm{GE}, \mathrm{WEC}$ & $\begin{array}{l}\text { Fuel holding pool, transfer canal, refueling cavity, } \\
\text { and upper containment fuel storage pool }\end{array}$ \\
\hline Spent fuel skimmer & GE & Fuel pool skimmer surge tank and drain tank \\
\hline Standby liquid control & GE & Standby liquid storage tank \\
\hline
\end{tabular}

1 Note that the dominant or prevailing tank/pool nomenclature was used; the possibility exists for plant-unique nomenclature differences. 


\subsubsection{NRC LER Database}

A search of the NRC LERs for vessels was performed to determine the extent of vessel failures in plants. The keyword "vessel" was used since the LER database does not have keywords such as "tanks" or "pools."

LERs, as defined and required by 10 CFR 50.72 [3.14] and 50.73 [3.15], are submitted to the NRC by nuclear power plant operators for many reasons. Some of the reasons that are applicable to the tanks/pools evaluated in this AMG include:

- Any operation or condition prohibited by the plant's technical specifications.

- Any event or condition that results in the condition of the nuclear power plant, including its principal safety barrier, being seriously degraded.

- Any event where a single cause or condition caused at least one independent train (e.g., DC power) to become inoperable in multiple systems or two independent trains to become inoperable in a single system.

A keyword search of tank/pool failures/degradation was performed on the LER database for the period up to December 21, 1993.[3.16, 3.17, 3.18]

The secondary screening process manually excluded those LERs having the same situations as listed for the NRPDS database (Section 3.4.1.1).

A review of the abstracts was performed to segregate those tanks/pools included in the scope of this AMG and where aging was identified as the primary cause of the tank/pool failure/degradation.

\subsubsection{Host Utility and Individual Plant Data}

Host utilities and participating utilities supported the development of the Tanks and Pools Aging Management Guideline with aging input and tank/pool component data. Host utilities supported the development of the AMG with system engineering interviews and data surveys. Host utility system engineer interviews were used to review site-specific aging management practices, validate generic industry data, and confirm the scope. Ten participating utilities provided aging management information to complete data surveys. Completed data surveys from the four host utilities are included in the appendices. Individual utilities are not cited on data surveys to maintain confidentiality.

\subsubsection{INPO Technical Library Database}

A keyword search of tanks/pools failures/degradation was performed on the INPO Technical Library database. $[3.19,3.20,3.21,3.22]$ A database search with the keywords "tanks" or "pools" was performed. This list was further refined manually to a list of records that exclude failures not classified as tanks/pools as defined in Section 3.2. 


\subsubsection{Other Industry Data}

A manual search of industry data was performed for "tanks" and "pools" and "vessels" using standard industry procedures and documents.

\subsubsection{Trending and Analysis of Data}

Data provided from the NPRDS and LER searches and plant data surveys was compiled to analyze the predominant failure mechanisms. The data from the INPO database was manually compiled due to limitations on their system for obtaining information pertaining specifically to tanks/pools.

\subsubsection{INPO NPRDS Database}

An "accumulator" word search of the NPRDS database yielded 445 records. A two-step review of the NPRDS records was performed to segregate tanks included in the scope of this AMG and then to further segregate those where aging was identified as the primary cause of tank failure/degradation. The first stage of data reduction (manual review) decreased the 445 records to 45 (Table 3-3 and Figure 3-4), or approximately $10 \%$ of the initial computergenerated records. By using the secondary screening criteria noted in Section 3.4.1.1, the population of applicable records was reduced to 11 . The breakdown of each particular failure as a percentage of the total applicable failures is presented in Figure 3-5.

The majority of the initial word search records were excluded since they related to the Chemical \& Volume Control System for the charging pump surge suppressors and the Standby Liquid Control System for the nitrogen accumulators. These components are not included in the scope of this AMG; see the Non-RCPB Piping and Tubing AMG.

\subsubsection{LER Database}

A "vessel" and "pools" word search of the LER database (Tables 3-4 and 3-5) provided 611 records. A two-step review of LER records was performed to segregate tanks/pools included in the scope of this AMG and to further segregate those where aging was identified as the primary cause of the tank/pool failure/degradation. The first manual review of the word search records reduced the population of records to 33 , or approximately $5 \%$ of the computergenerated word search records. By using the secondary screening criteria noted in Section 3.4.1.2, the population was further reduced to 13 records. The breakdown of each particular failure (record) as a percentage of the total applicable tank failures (records) is presented in Figure 3-6. Only two pool failures attributable to weld cracking were noted. 


\begin{tabular}{|c|c|c|}
\hline Mechanism for Failure & Number of Records & Evaluated in AMG \\
\hline Gasket Failure & $18 \quad(40 \%)$ & \\
\hline Contamination in Fuel & $3 \quad(7 \%)$ & \\
\hline $\begin{array}{l}\text { Improper Gasket } \\
\text { Specification }\end{array}$ & $1 \quad(2 \%)$ & \\
\hline Galvanic Corrosion & $1 \quad(2 \%)$ & $\checkmark$ \\
\hline Weld Failure & $4 \quad(9 \%)$ & $\checkmark$ \\
\hline $\begin{array}{l}\text { Float Control Valve } \\
\text { Wearing }\end{array}$ & $10(23 \%)$ & \\
\hline General Corrosion & $1 \quad(2 \%)$ & $\checkmark$ \\
\hline $\begin{array}{l}\text { General Fatigue of Internal } \\
\text { Tubing }\end{array}$ & $1 \quad(2 \%)$ & \\
\hline $\begin{array}{l}\text { Missing Support } \\
\text { Components }\end{array}$ & $1 \quad(2 \%)$ & \\
\hline \multirow[t]{2}{*}{ Leaky Fittings/Joints } & $5 \quad(11 \%)$ & $\checkmark$ \\
\hline & 45 of 445 possible & \\
\hline
\end{tabular}




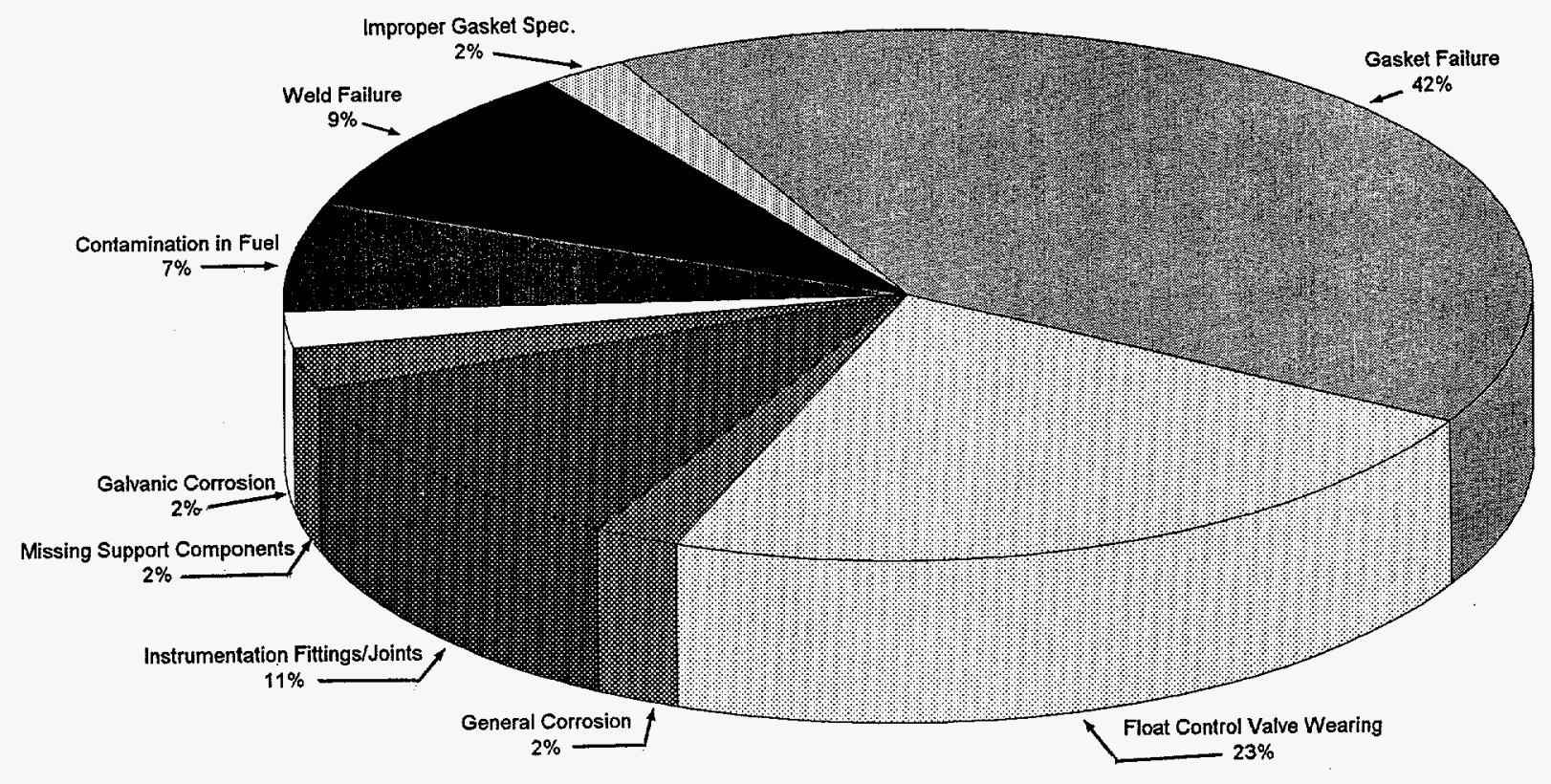

Figure 3-4. NPRDS Records from Search for Accumulators.

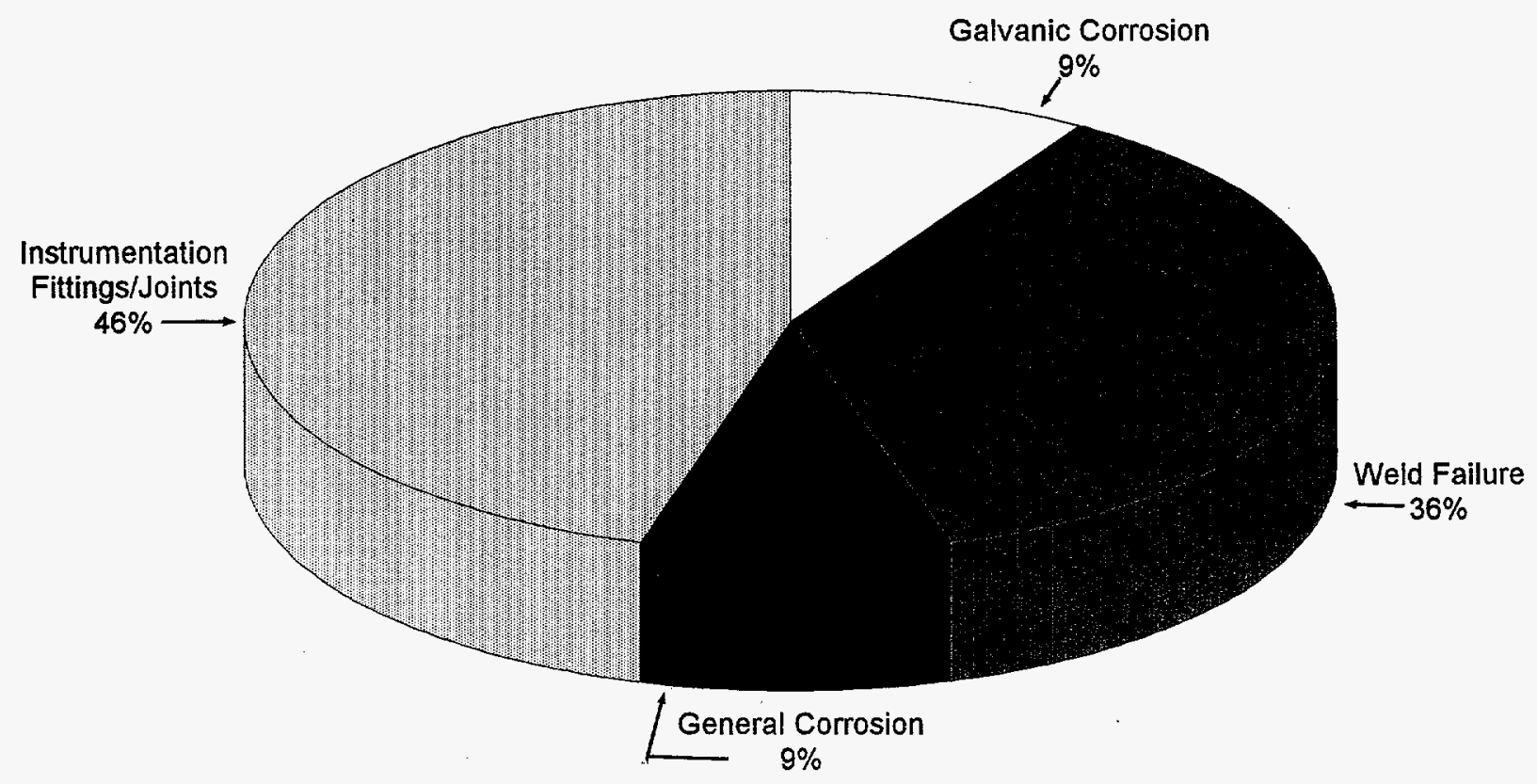

Figure 3-5. Tank Failures from NPRDS Data Evaluated in this AMG. 


\begin{tabular}{l|c|c}
\hline \hline \multicolumn{1}{c|}{ Table 3-4. LER Records from Search for Vessels } \\
\hline \hline \multicolumn{1}{c|}{ Mechanism for Failure } & Number of Records & Evaluated in AMG \\
\hline Weld Crack & 2 & $\checkmark$ \\
\hline Corrosion & 3 & $\checkmark$ \\
\hline Anchor Bolt Failure & 1 & \\
\hline Low Internal Pressure & 9 & \\
\hline Operational Mistake & 1 & \\
\hline Subcomponent Failure & 1 & \\
\hline Weld Failure in Liner & 3 & \\
\hline
\end{tabular}

Table 3-5. LER Records from Search for Pools

\begin{tabular}{l|c|c}
\hline \multicolumn{1}{c|}{ Mechanism for Failure } & Number of Records & Evaluated in AMG \\
\hline \hline Weld Crack & 2 & $\checkmark$ \\
\hline Valve Failure $^{(2)}$ & 4 & \\
\hline Instrumentation Failure $^{(1)}$ & 1 & \\
\hline Crack from Drop $^{(1)}$ & 1 & \\
\hline Operational Mistake $^{\text {Fatigue Failure in Pipe }}{ }^{(2)}$ & 4 & \\
\hline & 1 & \\
\hline
\end{tabular}

(1) Operational mistake where equipment dropped onto liner, causing crack.

(2) Failures included for reference only. 


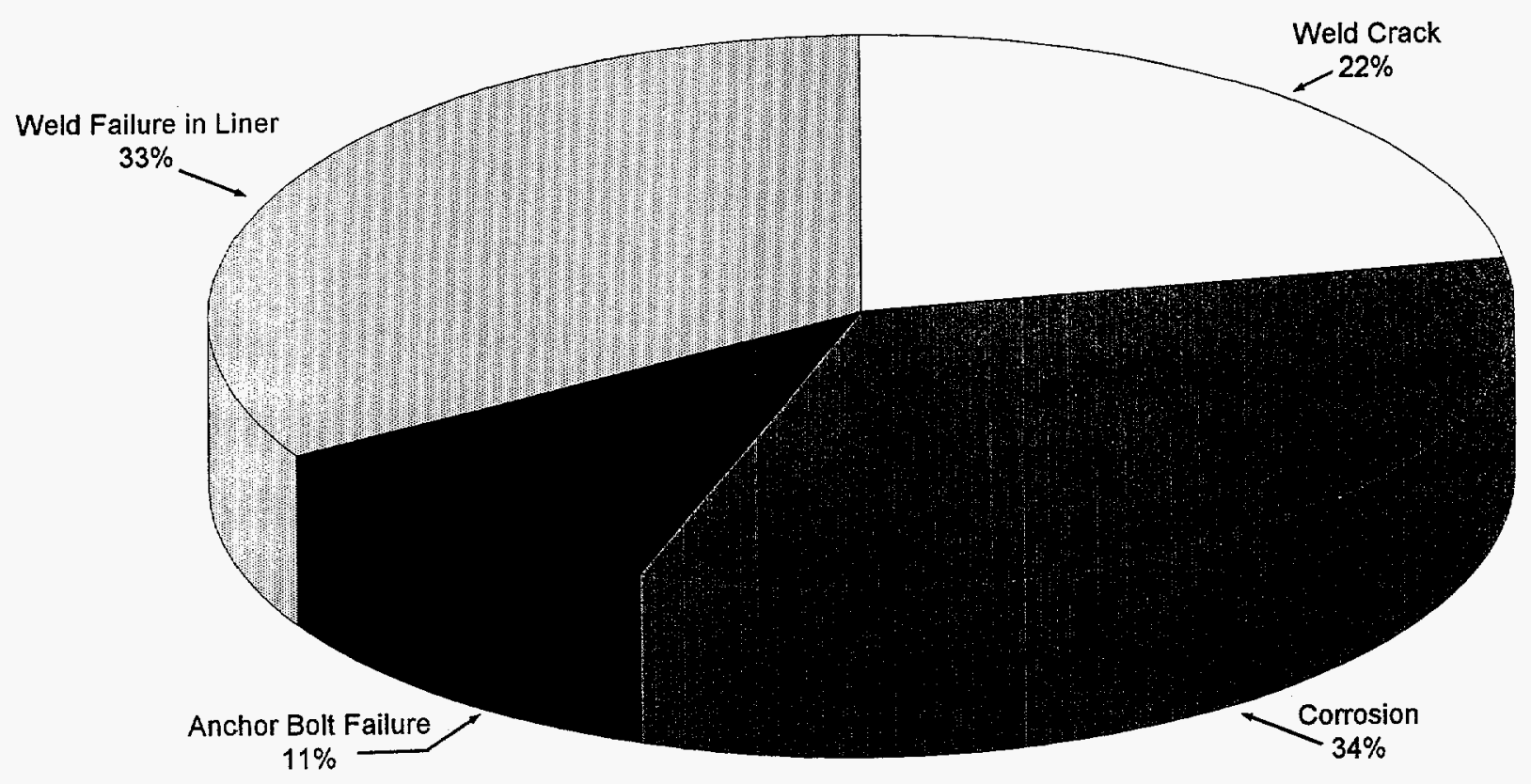

Figure 3-6. LER Records from Search for Vessels Evaluated in AMG.

\subsubsection{Host Utility and Individual Plant Data}

Four utilities served as host utilities for this AMG. Each utility provided relevant information for input into the AMG. Appendix D is the data survey used to gather data. Sections 4 and 5 of this AMG provide a detailed analysis of this data, with Section 4 determining the aging effects and Section 5 providing methods of mitigating those effects. As stated in Section 3.4, the tanks/pools degradation identified in host utility responses was enveloped by LER and NPRDS data.

\subsubsection{INPO Technical Library Database}

A total of 72 records meeting the "tanks" and "pool" word search were found. A manual screening of those records eliminating failures not attributable to the respective tanks/pools was performed. "Tanks" and "pools" not within this AMG, such as pressure vessels, along with Significant Event Reports (SERs)/Significant Operating Experience Reports (SOERs) were eliminated to reduce the population to 14 records noted in Table 3-6. A similar search of all SOERs and SERs was performed to identify the 20 records noted in Table 3-7. Note that selected records for pressure vessels were included where this information may potentially complement in-scope tanks and pools records.

The information in Tables 3-6 and 3-7 is consistent with NPRDS and LER data in that a majority of significant industry events associated with tanks and pools can be attributed to 


\begin{tabular}{|c|c|c|c|}
\hline \multicolumn{4}{|c|}{ Tanks } \\
\hline Identifier & Type & Title & Date \\
\hline C77-10 & NRC CIRCULAR & $\begin{array}{l}\text { Vacuum Conditions Resulting in Damage to Liquid } \\
\text { Process Tanks }\end{array}$ & $7 / 15 / 77$ \\
\hline N79-07 & $\begin{array}{l}\text { INFORMATION } \\
\text { NOTICE (NRC) }\end{array}$ & Rupture of Radwaste Tanks & $3 / 26 / 79$ \\
\hline B80-05 & NRC BULLETIN & $\begin{array}{l}\text { Vacuum Condition Resulting in Damage to CVCS } \\
\text { Holdup Tanks }\end{array}$ & $3 / 10 / 80$ \\
\hline SI81-021 & $\begin{array}{l}\text { TECHNICAL } \\
\text { REPORT (B\&W) }\end{array}$ & Davis-Besse Core Flood Tank & $11 / 25 / 81$ \\
\hline N85-33 & $\begin{array}{l}\text { INFORMATION } \\
\text { NOTICE }\end{array}$ & $\begin{array}{l}\text { Undersized Nozzle to Shell Welded Joints in Tanks and } \\
\text { Heat Exchangers Constructed Under the Rules of the } \\
\text { ASME Boiler and Pressure Vessel Code }\end{array}$ & $4 / 22 / 85$ \\
\hline NP6276 & $\begin{array}{l}\text { FINAL REPORT, } \\
\text { EPRI REPORT }\end{array}$ & $\begin{array}{l}\text { Earthquake Experience Data on Anchored Ground } \\
\text { Mounted Vertical Storage Tanks }\end{array}$ & $3 / 31 / 89$ \\
\hline NP6500 & $\begin{array}{l}\text { INTERIM } \\
\text { REPORT, EPRI } \\
\text { REPORT } \\
\end{array}$ & $\begin{array}{l}\text { Effects of Soil Structure Interaction of Laterally } \\
\text { Excited Liquid Storage Tanks }\end{array}$ & $9 / 30 / 89$ \\
\hline NSDTB81-07 & $\begin{array}{l}\text { WESTINGHOUSE } \\
\text { TECH. REPORT }\end{array}$ & Boron Injection Tank Leaks & $6 / 18 / 91$ \\
\hline \multicolumn{4}{|c|}{ Pools } \\
\hline Identifier & Type & Title & Date \\
\hline NP2531 & $\begin{array}{l}\text { INTERIM } \\
\text { REPORT, EPRI } \\
\text { REPORT }\end{array}$ & $\begin{array}{l}\text { Intergranular Stress Corrosion Cracking of Austenitic } \\
\text { Stainless Steel in PWR Boric Acid Storage Systems }\end{array}$ & $8 / 31 / 82$ \\
\hline N88-65 & $\begin{array}{l}\text { INFORMATION } \\
\text { NOTICE (NRC) }\end{array}$ & Inadvertent Drainage of Spent Fuel Pools & $8 / 18 / 88$ \\
\hline N88-92, SUP 1 & $\begin{array}{l}\text { INFORMATION } \\
\text { NOTICE }\end{array}$ & Potential for Spent Fuel Pool Draindown & $11 / 29 / 91$ \\
\hline N93-83 & $\begin{array}{l}\text { INFORMATION } \\
\text { NOTICE (NRC) }\end{array}$ & $\begin{array}{l}\text { Potential Loss of Spent Fuel Pool Cooling following a } \\
\text { Loss of Coolant Accident }\end{array}$ & $10 / 07 / 93$ \\
\hline B94-01 & NRC BULLETIN & $\begin{array}{l}\text { Potential Fuel Pool Draindown caused by inadequate } \\
\text { Maintenance Practices at Dresden Plant }\end{array}$ & $04 / 14 / 94$ \\
\hline N94-38 & $\begin{array}{l}\text { INFORMATION } \\
\text { NOTICE (NRC) }\end{array}$ & $\begin{array}{l}\text { Results of a Special NRC Inspection at Dresden } \\
\text { Nuclear Power Station Unit } 1 \text { following a Rupture of } \\
\text { Service Water inside Containment }\end{array}$ & $05 / 27 / 94$ \\
\hline
\end{tabular}


Table 3-7. SOERs and SERs Applicable to Tanks and Pools

Significant Operating Experience Reports (SOERs) related to tanks/pools:

None Found

Significant Event Reports (SERs) related to tanks/pools:

$\underline{\text { No.Yr }} \underline{\text { Title }}$

Date

26-80 Refueling Water Storage Tank Isolation Valve Failed to Operate

$06 / 24 / 80$

31-80 Inadvertent Contamination of Primary Makeup Water Tank

$07 / 14 / 80$

51-81 Spent Fuel Pool Watertight Gate Seals

$07 / 28 / 81$

61-81 Inadvertent Spent Fuel Pool Overflow

$08 / 12 / 81$

67-81 Gaseous Waste Decay Tank Hydrogen Burn

$09 / 10 / 81$

56-83 Tank Damage due to Inadequate Venting

$08 / 11 / 83$

02-84 Diesel Generator Fuel Oil Storage Tank Lining Failures and

$01 / 06 / 84$

38-84 Tank Damage Caused by Excessive Pressure or Vacuum

$05 / 14 / 84$

72-84 Reactor Cavity Seal Ring Failure

$10 / 03 / 84$

72-84-10

$04 / 18 / 85$

72-84-2

$02 / 12 / 86$

80-84 Inadvertent Depressurization of the RCS to the Refueling Water Storage Tank

$11 / 15 / 84$

92-84 Partial Drainage of Spent Fuel Storage Pool to Spent Fuel Shipping

$12 / 27 / 84$

12-85 Upper Head Injection Water Accumulator Tank Instrumentation Problems

$03 / 13 / 85$

09-86 Inadvertent Draining of Refueling Shield Tank

$02 / 24 / 86$

40-86 Spent Fuel Pool Leakage

$12 / 24 / 86$

20-87 Partial Draining of Upper Fuel Pool

$09 / 25 / 87$

19-88 Radioactive Demineralizer Resin Drains to Condensate Storage Tank

$06 / 21 / 88$

31-88 Reactor Cavity Seal Failure from Deflation and Inadequate Design

$10 / 27 / 88$

01-91 Spent Fuel Pool Overflow Events

$01 / 04 / 91$ 
operational problems or errors. The remaining reports are associated with design issues with the following two records having specific aging management applicability:

- EPRI NP2531, "Intergranular Stress Corrosion Cracking of Austenitic Stainless Steel in PWR Boric Acid Storage Systems"

- INPO SER 02-84, "Diesel Generator Fuel Oil Storage Tank Lining Failures and Incompatibility of Fuel Oil with Tank Coatings"

\subsubsection{Industry Standards}

The design of atmospheric and 0-15 psi tanks discussed in this AMG is generally based on ASME Boiler and Pressure Vessel Code Section III requirements [3.2, 3.3]. The design of spent fuel storage pools discussed in this AMG is generally based on ANS 57.2, "Design Requirements for Light Water Reactor Spent Fuel Storage Facilities at Nuclear Power Plants." [3.4]

Additional industry standards were searched for design, operation, or maintenance guidance. A summary of those standards that contain information applicable to the aging analysis (materials) or aging management program evaluation (maintenance practices/operations) is identified in Table 3-8. Additional content details of the standards noted in Table 3-8 and some additional potentially applicable standards are noted in Appendix C.

This AMG uses the description of tanks as found in ASME Section III to determine the applicability of aging mechanisms. Tanks have been designed to a variety of codes/standards, some of which are listed in Table 3-9. After a review of many of the industry standards for tanks, it was determined that ASME III provides the most generic description of tanks, so that the largest amount of tanks are included in the AMG scope. 
Table 3-8. Industry Standards for Tanks/Pools ${ }^{1}$

\begin{tabular}{|c|c|}
\hline Code/Standard & Applicability \\
\hline API 650 & Welded Steel Tanks for Oil Storage \\
\hline API 653 & Tank Inspection, Repair, Alteration, and Reconstruction \\
\hline API 1631 & Interior Lining of Underground Storage Tanks \\
\hline API 1632 & $\begin{array}{l}\text { Cathodic Protection of Underground Petroleum Storage Tanks and } \\
\text { Piping Systems }\end{array}$ \\
\hline ASTM D4021-86 & $\begin{array}{l}\text { Standard Specification for Glass-Fiber-Reinforced Polyester } \\
\text { Underground Storage Tanks }\end{array}$ \\
\hline AWWA D-100 & Welded Steel Tanks for Water Storage \\
\hline NACE RP-0184-84 & Repair of Lining Systems \\
\hline NACE RP-0285-85 & $\begin{array}{l}\text { Control of External Corrosion of Metallic Buried, Partially Buried, } \\
\text { or Submerged Liquid Storage Systems }\end{array}$ \\
\hline NFPA 327 & Cleaning or Safeguarding Small Tanks and Containers \\
\hline NLPA Standard 631 & $\begin{array}{l}\text { Spill Prevention, Minimum 10-Year Life Extension of Existing Steel } \\
\text { Underground Tanks by Lining Without the Addition of Cathodic } \\
\text { Protection }\end{array}$ \\
\hline PEI RP100-90 & $\begin{array}{l}\text { Recommended Practices for Installation of Underground Liquid } \\
\text { Storage Systems }\end{array}$ \\
\hline STI R831-87 & $\begin{array}{l}\text { Optional Recommended Practice for Control of Localized Corrosion } \\
\text { Within Underground Steel Petroleum Storage Tanks }\end{array}$ \\
\hline STI R893-89 & $\begin{array}{l}\text { Recommended Practice for External Corrosion Protection of Shop } \\
\text { Fabricated Aboveground Steel Storage Tank Floors }\end{array}$ \\
\hline
\end{tabular}

1 Appendix C contains additional codes/standards applied to industry tanks. 


\begin{tabular}{|c|c|c|}
\hline Code/Standard & Description & Applicability \\
\hline API 650 & $\begin{array}{l}\text { open-top, welded steel storage } \\
\text { tanks }\end{array}$ & $\begin{array}{l}\text { covers material, design, } \\
\text { fabrication, erection, and testing } \\
\text { requirements for vertical } \\
\text { cylindrical above-ground, closed } \\
\text { and open-top, welded steel storage } \\
\text { tanks in various sizes and } \\
\text { capacities for internal pressures } \\
\text { approximating atmospheric } \\
\text { pressure }\end{array}$ \\
\hline ASTM D4021 & $\begin{array}{l}\text { underground tanks for } \\
\text { atmospheric pressure }\end{array}$ & $\begin{array}{l}\text { covers glass-fiber-reinforced } \\
\text { horizontal, cylindrical, and } \\
\text { spherical-type underground tanks } \\
\text { for atmospheric pressure storage } \\
\text { of petroleum-based fuels and oils }\end{array}$ \\
\hline ASME Section III & $\begin{array}{l}\text { above-ground welded storage } \\
\text { tanks }\end{array}$ & $\begin{array}{l}\text { above-ground welded storage } \\
\text { tanks at } 0 \text { to } 15 \text { psi pressure }\end{array}$ \\
\hline ASME Section VIII & $\begin{array}{l}\text { pressure vessels (greater than } 15 \\
\text { psi excluded) }\end{array}$ & $\begin{array}{l}\text { pressure vessels are containers for } \\
\text { the containment of pressure, } \\
\text { either internal or external }\end{array}$ \\
\hline ASME Section $\mathrm{X}$ & $\begin{array}{l}\text { pressure vessels (greater than } 15 \\
\text { psi excluded) }\end{array}$ & $\begin{array}{l}\text { establishes the minimum } \\
\text { requirements for the fabrication of } \\
\text { fiber-reinforced thermosetting } \\
\text { plastic pressure vessels for } \\
\text { general service, sets limitations on } \\
\text { the permissible service conditions, } \\
\text { and defines the types of vessels to } \\
\text { which these rules are not } \\
\text { applicable }\end{array}$ \\
\hline AWWA D-100 & $\begin{array}{l}\text { steel tanks, standpipes, reservoirs, } \\
\text { or elevated tanks, for water } \\
\text { storage }\end{array}$ & $\begin{array}{l}\text { covers design and installation of } \\
\text { steel tanks, standpipes, reservoirs, } \\
\text { or elevated tanks, for water } \\
\text { storage }\end{array}$ \\
\hline
\end{tabular}




\subsection{References}

3.1 NUMARC 93-02, A Report on the Verification and Validation of NUMARC 9301, Draft Revision 2A, "Industry Guideline for Monitoring the Effectiveness of Maintenance at Nuclear Power Plants," May 1993.

3.2 American Society of Mechanical Engineers Boiler and Pressure Vessel Code, Section III, Rules for Construction of Nuclear Power Plant Components, Division 1, Subsection ND-3800, "Design of Atmospheric Storage Tanks," 1989 with 1994 addenda.

3.3 American Society of Mechanical Engineers Boiler and Pressure Vessel Code, Section III, Rules for Construction of Nuclear Power Plant Components, Division 1, Subsection ND-3900, "Design of 0-15 psi Storage Tanks," 1989 with 1994 addenda.

3.4 ANSI/ANS-57.2-1983, "Design Requirements for Light Water Reactor Spent Fuel Storage Facilities at Nuclear Power Plants."

3.5 ANSI/ANS-57.7-1981, "Design Criteria for an Independent Spent Fuel Storage Installation (Water Pool Type)."

3.6 NUREG/CR-4731, "Residual Life Assessment of Major Light Water Reactor Components," Volume 1, November 1989.

3.7 NUREG/CR-4731, "Residual Life Assessment of Major Light Water Reactor Components - Overview," Volume 2, November 1989.

3.8 EPRI Report TR-103836, "BWR Reactor Pressure Vessel License Renewal Industry Report," Revision 1, July 1994.

3.9 EPRI Report TR-103837s, "PWR Reactor Pressure Vessel License Renewal Industry Report," Revision 1, July 1994.

3.10 EPRI Report TR-103840, "BWR Containments License Renewal Industry Report," Revision 1, July 1994.

3.11 Regulatory Guide 1.143, "Design Guidance for Radioactive Waste Management Systems, Structures, and Components Installed in Light-Water-Cooled Nuclear Plants, Revision 1," October 1979.

3.12 EPRI Report TR-103842, "Class I Structures License Renewal Industry Report," Revision 1, July 1994.

3.13 INPO Records Center Report NPRS01AA, "NPRDS ACCUM," Job 2321, December 15, 1993. 
3.14 Title 10, U.S. Code of Federal Regulations, 10 CFR Part 50.72, "Immediate Notification Requirements for Operating Nuclear Power Reactors," January 1, 1994, pp. 704-706.

3.15 Title 10, U.S. Code of Federal Regulations, 10 CFR Part 50.73, "Licensee Event Report System," January 1, 1994, pp. 706-709.

3.16 INPO Records Center Report RCRA000A, "LER VESSEL, " Job 8854, December $21,1993$.

3.17 INPO Records Center Report RCRA000A, "LER VESSELS," Job 8862, December 21, 1993.

3.18 INPO Records Center Report RCRA000A, "LER POOLS," Job 8747, December 20, 1993.

3.19 INPO Records Center Report RCRA000A, "TLIB TANKS, " Job 8846, December 21, 1993.

3.20 INPO Records Center Report RCRA000A, TLIB POOLS," Job 8742, December 20, 1993.

3.21 INPO Records Center Report RCRA120A, "SOERs \& SERs," December 20, 1993.

3.22 INPO Records Center Report, "DOC INDEX," Job 8749, December 20, 1993. 


\section{APPLICABLE STRESSORS AND AGING MECHANISMS}

The purpose of this section is to provide a technical basis for reviewing tanks and pools for potential degradation due to aging. There are presently several industry and NRC-sponsored research programs directed toward identifying component aging. The goals of these research programs are to increase power plant reliability and public safety by improving component reliability. The methodology for identifying potential tank and pool aging mechanisms is based on these research programs and the operating experiences from several different nuclear power plants. Listed below are the major tasks associated with this methodology:

1. Identification of stressors

2. Identification of potential aging mechanisms

3. Identification of key decision parameters

4. Development of key decision parameter screening values (i.e., "if-then" threshold criteria)

5. Development and review of material aging analysis diagrams

Those individuals who are not interested in the evaluation of aging mechanisms but are interested in the effects of aging and effective aging management practices can skip Section 4 and begin again in Section 5, page 5-1.

\subsection{Determination of Stressors Acting on Tanks and Pools}

A stressor is a physical state or stimulus caused by fabrication, installation, operational conditions, or environmental conditions that may result in tank or pool degradation. Materials used during manufacture, assembly, and installation are subject to some degradation due to residual and applied stressors. Also, stressors caused by normal operation and environmental conditions affect the potential for aging mechanisms to cause component degradation. It is therefore important to understand a material's behavior to satisfactorily operate a tank or pool and develop degradation detection and mitigation methods.

Steady state, cyclic, and peak stressors may act on components during any modes of operation. The stressors acting on tanks and pools are:
a. Mechanical
b. Hydraulic
c. Chemical
d. Electrical
e. Environmental

- Thermal

- Moisture

- Radiation 
Stressors cause tank and pool degradation through aging mechanisms. If left unmitigated, these aging mechanisms result in component degradation and potentially unacceptable performance or failure. The following sections provide a detailed description of the stressors that can affect tanks and pools.

\subsubsection{Mechanical Stressors}

Tanks and pools are subject to a variety of mechanical stressors. During assembly, stressors are induced in components due to welding of tank/pool segments, fit-up, erection tolerance, and fastener tightening. These induced stressors are classified as assembly loads. Piping systems attached to the tank and pool nozzles exert thrust and moments on the nozzles. The stress caused by these piping loads is dependent upon nozzle misalignment, piping movement due to thermal expansion and contraction, material condition, and condition of the piping hanger/support network. Piping loads are distributed through the nozzles to the tank or pool shell.

\subsubsection{Hydraulic Stressors}

Process fluid pressure and flow are examples of hydraulic stressors. The loads from hydraulic stressors are dependent upon the process fluid characteristics, component design, and operating environment.

Fluid pressures exert mechanical stress on the component shell and nozzles. Tanks and pools are designed to withstand normal and accident condition pressures. However, process fluid flows may cause components to degrade due to many different aging mechanisms, such as erosion/corrosion, microbiologically influenced corrosion (MIC), or crevice/pitting corrosion.

\subsubsection{Chemical Stressors}

Process fluids can chemically react with components causing corrosion. This reaction results in stresses that are the result of the chemical reactions between the metal and the liquid. The stress can be localized or uniformly distributed. The tanks and pools covered by this AMG contain many different types of process liquids and gases. Types of liquid are reactor water, demineralized water, well water, river water, city or fresh water, brackish water, sea water, condensate, water with chromates added, and lubricating oils.

In addition to the chemical stressors caused by the process fluid, some tanks and pools are exposed to other harsh external environments (e.g., salt spray) that can also lead to corrosion.

All liquids act as electrolytic solutions. An electrolyte is an electrical conducting medium that allows electrons to flow between an anode and cathode. Metallic components act as both anodes and cathodes depending on the materials. Corrosion occurs when electrons leave an anodic material and enter the electrolytic solution and flow to the more cathodic material. High fluid conductivity results in a greater rate of corrosion, because current flows better in less resistive circuits. 
Another form of chemical stressor acting on the metallic component surfaces is the influence of living organisms on the corrosion process. In some circumstances, microbial activity provides a localized environment where concentration cells are established, promoting accelerated corrosion. In other cases MIC occurs, where microbes produce organic or mineral acids, ammonia, or hydrogen sulfide that corrodes metals. Microbial activity also can interfere with the cathodic half-reaction in oxygen-free environments, causing an increased anodic dissolution. In other ways, microbes can influence the (1) solubility of metal ions, (2) integrity of protective coatings, and (3) metabolism of inhibitors. [4.1]

The "structural foundation material" for pool liners is subject to chemical stressors. Reinforced concrete is the most common "structural foundation material" used as the backing/support mechanism for pool liner plates, both wall and floor plate. Structural reinforced concrete can be attacked as a result of pool liner plate failures or spills of pool liquids. Exposure of the reinforced concrete material system to the pool liquid can cause deterioration and potential loss of function.

\subsubsection{Electrical Stressors}

The electrical stressor affecting tanks and pools is caused by galvanic corrosion, which results from the coupling of dissimilar materials (see Table 4-1). The potential for galvanic corrosion can be reduced by using sacrificial anodes (usually zinc or magnesium). See the discussion in Section 4.1.3 for details regarding electrochemical corrosion.

\subsubsection{Environmental Stressors}

Environmental stressors can be grouped into the three following categories:

- Thermal - internal process fluid temperature and external ambient temperature

- Moisture - external ambient humidity

- Radiation - cumulative radiation exposure

\subsubsection{Thermal Stressors}

Thermal stresses are present whenever the operating temperature is different from the fabrication/installation temperature. However, these stresses are accounted for in the design of the tank or pool.

Thermal expansion or contraction acting against a constraint also causes thermal stress. Constraints may be external or internal to the tank or pool. Also, in thick parts, temperature gradients are likely to occur along and through the material, causing thermal stresses.

Exposure of metal parts to high and low temperatures, often accompanied by nonuniform heating rates and sharp thermal gradients, is a source of stress. [4.2] This stress is referred to as thermal fatigue. In addition, when the metal is exposed to a corrosive environment, the resulting localized electrochemical dissolution of metal, combined with localized plastic 
Table 4-1. Galvanic Series

Anodic End of Galvanic Series

Magnesium

Magnesium Alloys

Zinc

Aluminum 5052

Aluminum 6061

Cadmium

Aluminum AA 2017

Iron and Carbon Steel

Copper Steel

$4 \%$ to $6 \%$ Chromium Steel

Ferritic Stainless (active) 400 Series

Austenitic Stainless (active) 18-8 Series

Lead-Tin Solder

Lead

Tin

Nickel (active)

Inconel (active)

Hastelloy C (active)

Brasses

Copper

Bronze

Cupro-Nickel Alloys

Monel

Silver Solder

Nickel (passive)

Inconel (passive)

Ferritic Stainless (passive)

Austenitic Stainless (passive)

Titanium

Hastelloy C (passive)

Silver

Graphite

Gold

Platinum

Cathodic End of Galvanic Series 
deformation, creates a crack. With sustained tensile stress, protective films that form at the tip of the crack rupture, causing fresh anodic material to be exposed to the corrosive medium, and further tip corrosion is propagated.[4.2] This aging mechanism is called corrosion fatigue.

\subsubsection{Moisture Stressors}

Atmospheric humidity can result in general, galvanic, or crevice/pitting corrosion. In these forms of corrosion, the stresses are electrochemical, and are described in Section 4.1.3.

\subsubsection{Radiation Stressors}

Neutron collisions with materials produce primary recoil atoms that displace other atoms. Experimental data shows that after prolonged exposure to neutrons, the component material yield strength can increase by a factor of three (depending on material type) over its unirradiated value. Although the yield strength increases, the material's ability to elongate drops, its fracture toughness drops, and the tearing modulus drops.[4.3] These material property changes are described as neutron embrittlement.

The extent of embrittlement depends on neutron fluence, material type, irradiation temperature, and trace material chemistry (i.e., particularly the presence of copper, phosphorus, and nickel).[4.4] The degree of embrittlement is expressed as an upward shift of the brittle-toductile transition temperature with a decrease in the upper shelf energy. Embrittlement is measured using the Charpy impact energy test.[4.5]

A form of stress corrosion cracking can occur in austenitic stainless steel and Inconel components under highly irradiated conditions. Irradiation assisted stress corrosion cracking, or IASCC, involves the simultaneous interaction of a highly irradiated material, high-temperature water, and gamma and neutron fluxes.[4.6] It is important to note that IASCC (see Section E.2) does not require chromium depletion or high stresses required for IGSCC (see Section 4.2.2.1). An approximate threshold for IASCC is $5 \times 10^{20}$ neutrons $/ \mathrm{cm}^{2}$ [ $>1 \mathrm{MeV}$, energy level], for both austenitic stainless steel and Inconel 800 [4.7], below which IASCC is non-significant.

\subsection{Description of Potential Tank and Pool Aging Mechanisms}

This section and Appendix E provide a comprehensive discussion of all aging mechanisms that could potentially cause tanks and pools to degrade in a nuclear power plant environment. Sections 4.3.1 and 4.3.2 summarize the aging mechanisms that are potentially significant and non-significant, respectively, for the tanks and pools found at a nuclear power station.

A comprehensive list of all aging mechanisms (AMs) that could be applicable to tanks and pools is as follows:

1) Fatigue

2) Corrosion

3) Stress corrosion cracking (SCC)

4) Erosion/corrosion (E/C)

5) Two-phase erosion 
6) Embrittlement

7) Wear

8) Stress relaxation

9) Creep

10) Integranular attack (IGA)

11) Hydrogen damage

12) Aggressive chemical attack and corrosion of embedded steel/rebar (pools only)

Tables 4-2 and 4-3 summarize the materials, fluids, aging effects and failure modes typically associated with these potential aging mechanisms. It will be determined (see below and Appendix E) that the only potentially significant AMs are:

1) Corrosion

2) $\mathrm{SCC}$

3) $\mathrm{E} / \mathrm{C}$

4) Two-phase erosion

5) IGA

6) Hydrogen damage

7) Aggressive chemical attack and corrosion of embedded steel/rebar (pools only)

To reduce the amount of material the reader should focus on, descriptions of the nonsignificant AMs (e.g., fatigue, etc.) have been moved to Appendix E and the remainder of Section 4.2 covers only those AMs that are potentially significant.

Reference 4.8 and plant operating experiences were the primary sources for identification of the applicable aging mechanisms. References 4.8 and 4.9 and plant operating experiences were the primary sources for identification of the applicable pool structural aging mechanisms.

\subsubsection{Corrosion}

Corrosion is the deterioration of a material due to electrochemical reactions with its environment. It is characterized by material loss or deterioration of its mechanical properties. Corrosion reduces the component wall thickness, either locally (e.g., crevice corrosion, pitting, galvanic corrosion, microbiologically influenced corrosion, etc.) or more uniformly (e.g., general corrosion). The resultant decrease in the material volume causes a decrease in its strength. Furthermore, the associated surface roughening can cause additional weakening of the material by creating the stress risers.

\subsubsection{General/Uniform Corrosion}

General/uniform corrosion of metal surfaces is caused by the combined effects of film formation and film breakdown. Film formation produces a protective oxide layer on the metal surface. This film is created by a chemical reaction with the metal, oxygen, and moisture. External forces and stresses internal to the oxide layer produces cracks, disruptions, and discontinuities in the film. Moisture in the surrounding environment then provides an electrolyte and a path for electrochemical reactions to occur, producing another oxide layer. The entire process then repeats itself. 
AGING MANAGEMENT GUIDELINE FOR TANKS AND POOLS

\begin{tabular}{|c|c|c|c|c|c|}
\hline Section & Potential Aging Mechanism & Aging Effects & Failure Modes & Susceptible Material & Typical Fluids \\
\hline \multirow[t]{5}{*}{ 4.2.1 Corrosion } & General Corrosion & Wall thinning & Seepage/leakage & $\begin{array}{l}\text { - Carbon steel } \\
\text { - Cast iron } \\
\text { - Ferritic SS } \\
\text { - Low alloy steels } \\
\text { - Martensitic SS } \\
\text { - Aluminum }\end{array}$ & $\begin{array}{l}\text { - Moist air } \\
\text { - Aqueous fluids } \\
\text { - Soils }\end{array}$ \\
\hline & Selective Leaching & $\begin{array}{l}\text { - Crack initiation } \\
\text { - Wastage }\end{array}$ & Seepage/leakage & $\begin{array}{l}\text { - Cast iron } \\
\text { - Aluminum alloys } \\
\text { - Concrete } \\
\text { - Copper alloys } \\
\end{array}$ & Aqueous fluids \\
\hline & $\begin{array}{l}\text { Pitting and Crevice } \\
\text { Corrosion }\end{array}$ & $\begin{array}{l}\text { - Pits } \\
\text { - Crack initiation }\end{array}$ & Seepage/leakage & All & Water \\
\hline & Galvanic Corrosion & $\begin{array}{l}\text { - Wall thinning } \\
\text { - Crack initiation } \\
\text { - Pitting } \\
\end{array}$ & Seepage/leakage & All & Water \\
\hline & MIC & $\begin{array}{l}\text { - Pits } \\
\text { - Crack initiation }\end{array}$ & Seepage/leakage & All & $\begin{array}{l}\text { - Water } \\
\text { - Fuel oil } \\
\text { - Soils } \\
\end{array}$ \\
\hline \multirow[t]{2}{*}{$\begin{array}{l}\text { 4.2.2 Stress } \\
\text { Corrosion Cracking } \\
\text { (SCC) }\end{array}$} & IGSCC & Cracking & Seepage/leakage & $\begin{array}{l}\text { - Inconel } \\
\text { - Copper alloys } \\
\text { - Non-base austenitic SS }\end{array}$ & Water \\
\hline & IASCC & Cracking & Fracture & $\begin{array}{l}\text { - Inconel } \\
\text { - Monel } \\
\text { - Non-case austenitic SS }\end{array}$ & All \\
\hline
\end{tabular}


AGING MANAGEMENT GUIDELINE FOR TANKS AND POOLS

\begin{tabular}{|c|c|c|c|c|c|}
\hline Section & Potential Aging Mechanism & Aging Effects & Failure Modes & Susceptible Material & Typical Fluids \\
\hline $\begin{array}{l}\text { 4.2.2 Stress } \\
\text { Corrosion Cracking } \\
\text { (SCC) (continued) }\end{array}$ & TGSCC & Cracking & Seepage/leakage & $\begin{array}{l}\text { - Aluminum alloys } \\
\text { - Copper alloys } \\
\text { - Non-cast austenitic SS } \\
\text { - Martensitic SS }\end{array}$ & Water \\
\hline $\begin{array}{l}\text { 4.2.3 Erosion/ } \\
\text { Corrosion }\end{array}$ & Erosion/Corrosion & Wall thinning & Seepage/leakage & $\begin{array}{l}\text { - Aluminum } \\
\text { - Copper Alloys } \\
\text { - Carbon Steel } \\
\text { - Cast Irons } \\
\text { - Low alloay steels } \\
\text { - Concrete }\end{array}$ & Water \\
\hline $\begin{array}{l}\text { 4.2.4 Two-Phase } \\
\text { Erosion }\end{array}$ & Two-Phase Erosion & $\begin{array}{l}\text { - Wall thinning } \\
\text { - Pitting } \\
\text { - Wastage }\end{array}$ & Seepage/leakage & $\begin{array}{l}\text { - Aluminum } \\
\text { - Copper alloys } \\
\text { - Carbon steel } \\
\text { - Cast iron } \\
\text { - Low alloy steel } \\
\text { - Concrete } \\
\text { - Martensitic SS } \\
\text { - Ferritic SS }\end{array}$ & $\begin{array}{l}\text { - Wet stearin } \\
\text { - Two-phase water }\end{array}$ \\
\hline $\begin{array}{l}4.2 .5 \text { Intergranular } \\
\text { Attack }\end{array}$ & Intergranular Attack & Cracking & Seepage/leakage & $\begin{array}{l}\text { - Inconel } \\
\text { - Austenitic SS }\end{array}$ & Acid water based fluids \\
\hline $\begin{array}{l}\text { 4.2.6 Hydrogen } \\
\text { Damage }\end{array}$ & Hydrogen Damage & Blistering & Seepage/leakage & - Titanium & Corrosive Fluid \\
\hline \multirow[t]{2}{*}{$\begin{array}{l}\text { 4.2.7 Structural } \\
\text { Aging (Pools) }\end{array}$} & Aggressive Chemical Attack & $\begin{array}{l}\text { - Loss of material } \\
\text { - Cracking }\end{array}$ & $\begin{array}{l}\text { Structural failure } \\
\text { causing pool failure }\end{array}$ & Concrete & Borated water \\
\hline & $\begin{array}{l}\text { Corrosion of Embedded } \\
\text { Steel/Rebar }\end{array}$ & Wastage & $\begin{array}{l}\text { Structural failure } \\
\text { causing pool failure }\end{array}$ & Carbon Steel & Borated water \\
\hline
\end{tabular}




\section{AGING MANAGEMENT GUIDELINE FOR TANKS AND POOLS}

\begin{tabular}{|c|c|c|c|c|c|}
\hline Section & Potential Aging Mechanism & Aging Effects & Failure Modes & Susceptible Material & Typical Fluids \\
\hline E.1 Fatigue & Fatigue & Crack initiation & Seepage/leakage & All & All \\
\hline \multirow{8}{*}{$\begin{array}{l}\text { E.3.1 Thermal } \\
\text { Embrittlement }\end{array}$} & $475^{\circ} \mathrm{C}$ Embrittlement & Cracking & Seepage/leakage & Cast austenitic SS & All \\
\hline & Temper Embrittlement & Cracking & Seepage/leakage & Low alloy steels & All \\
\hline & $350^{\circ} \mathrm{C}$ Embrittlement & Cracking & Seepage/leakage & Low alloy steels & All \\
\hline & Blue Brittleness & Cracking & Seepage/leakage & $\begin{array}{l}\text { - Carbon steel } \\
\text { - Low alloy steels }\end{array}$ & All \\
\hline & Strain-Age Embrittlement & Cracking & Seepage/leakage & Carbon steel & All \\
\hline & $\begin{array}{l}\text { Graphitization } \\
\text { Embrittlement }\end{array}$ & Cracking & Seepage/leakage & $\begin{array}{l}\text { - Carbon steel } \\
\text { - Low alloy steel }\end{array}$ & All \\
\hline & Sigma Phase Embrittlement & Cracking & Seepage/leakage & $\begin{array}{l}\text { - Ferritic SS } \\
\text { - Austenitic SS }\end{array}$ & All \\
\hline & $400-550^{\circ} \mathrm{C}$ Embrittlement & Cracking & Seepage/leakage & Austenitic SS & All \\
\hline
\end{tabular}


AGING MANAGEMENT GUIDELINE FOR TANKS AND POOLS

\begin{tabular}{|c|c|c|c|c|c|}
\hline Section & Potential Aging Mechanism & Aging Effects & Failure Modes & Susceptible Material & Typical Fluids \\
\hline $\begin{array}{l}\text { E.3.2 Neutron } \\
\text { Embrittlement }\end{array}$ & Neutron Embrittlement & $\begin{array}{l}\text { - Loss of fracture toughness } \\
\text { - Loss of tearing modulus } \\
\text { - Increase of yield strength }\end{array}$ & Seepage/leakage & $\begin{array}{l}\text { - Carbon steels } \\
\text { - Low alloy steels } \\
\text { - Ferritic SS } \\
\text { - Martensitic SS } \\
\text { - Cast iron } \\
\text { - Inconel } \\
\text { - Austenitic SS }\end{array}$ & All \\
\hline \multirow[t]{3}{*}{ E.4 Wear } & Adhesive Wear & $\begin{array}{l}\text { - Wall thinning } \\
\text { - Buildup of unwanted materials }\end{array}$ & Dimension degradation & $\begin{array}{l}\text { - Copper alloys } \\
\text { - Aluminum alloys } \\
\text { - Austenitic SS } \\
\end{array}$ & All \\
\hline & Abrasive Wear & Wall thinning & Seepage/leakage & All & Non-clean water \\
\hline & Erosion & Wall thinning & Seepage/leakage & All & Non-clean water \\
\hline $\begin{array}{l}\text { E. } 5 \text { Stress } \\
\text { Relaxation } \\
\end{array}$ & Stress Relaxation & Plastic Deformation & $\begin{array}{l}\text { - Loose parts } \\
\text { - Loss of preload }\end{array}$ & All & All \\
\hline E.6 Creep & Creep & $\begin{array}{l}\text { - Elastic Deformation } \\
\text { - Plastic Deformation }\end{array}$ & $\begin{array}{l}\text { - Plastic deformation } \\
\text { - Seepage/leakage }\end{array}$ & All & All \\
\hline
\end{tabular}


The rate of general/uniform corrosion is highly dependent upon the availability and purity of the electrolyte. General/uniform corrosion rates also are dependent upon process fluid oxygen content, operating temperature, and flow rate. Very little general/uniform corrosion occurs in deoxygenated high temperature $\left(180^{\circ} \mathrm{C}\left[350^{\circ} \mathrm{F}\right]\right)$ water systems because a tough, black, oxide film (magnetite) forms, protecting the component's surfaces from further general/uniform corrosion.

Summary for General/Uniform Corrosion:

Typical Nuclear Plant Component Types - All typical fluid system components.

Susceptible Materials - Carbon steel, cast iron, ferritic stainless steels, low alloy steels, martensitic stainless steels, and aluminum.

Typical Nuclear Plant Fluids - Moist air, aqueous fluids, and soils which hold moisture.

Effects of Aging - Wall thinning.

Failure Modes - Seepage/leakage.

For More Detailed Information - See References 4.10, page 426; 4.3; 4.11; 4.8; 4.12, pages $6-1,4-89 ; 4.13$, pages $45,87,161 ; 4.14$, page $34 ; 4.15$, pages $181,226,236$; 4.16 , page $6-64 ; 4.17 ; 4.18$.

\subsubsection{Selective Leaching}

Selective leaching is a corrosion process that results in the removal of one element of an alloy. The most common forms of selective leaching are graphitization and dezincification.

Graphitization occurs when a corrosion process removes the iron matrix from a component fabricated of gray cast iron. The leaching removes the iron, leaving behind the insoluble graphite, which lacks strength. This process only occurs under harsh conditions (i.e., buried piping).

Dezincification is the selective removal of zinc from brass components. Copper-zinc alloys containing more than $15 \%$ zinc are susceptible to dezincification. Dezincification of copper-zinc alloys is most prevalent in waters containing oxygen, carbon dioxide, or chloride. Like most corrosion mechanisms, increasing the temperature of the fluid increases the dezincification rate. Also, stagnant fluids tend to produce higher dezincification rates.

Excessive chlorination of cooling water also may promote dezincification of copper-zinc alloys. Dealloying is a corrosion process in which the more active metal is selectively removed from an alloy (i.e., zinc), leaving behind a weak, porous layer of the more noble metal (i.e., copper and copper oxide). Where dezincification is a problem, red brass, commercial bronze, inhibited admiralty metal, and inhibited aluminum brass can be successfully used. 
In addition to copper alloys and gray cast iron, aluminum bronzes also may experience selective leaching. Selective leaching can occur in aluminum bronze when exposed to sulfuric and other acids. Duplex structures are more susceptible, and chlorides tend to accelerate the leaching process. [4.12]

Summary for Selective Leaching:

Typical Nuclear Plant Component Types - All typical fluid system components.

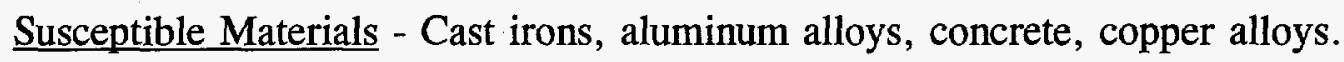

Typical Nuclear Plant Fluids - Aqueous fluids.

Effects of Aging - Crack initiation.

Failure Modes - Seepage/leakage with the potential for rupture when high component stresses are present.

For More Detailed Information - See References 4.13, pages 45, 86, 135; 4.15, pages $86-89 ; 4.16$, pages 6-60, 6-65.

\subsubsection{Pitting and Crevice Corrosion}

Crevice/pitting corrosion results in localized corrosion of a component. It occurs in stagnant flow areas that allow material or environmentally produced impurities to concentrate. The impurity concentration may be caused by alternate wetting and drying, by precipitation of a chemical species, or the collection of insoluble impurities found in fluid systems.

Crevice corrosion, as the name implies, occurs in crevices, such as those formed between a flange face and its gasket. Pitting corrosion usually occurs on the lower surface of horizontal runs of piping or other fluid component surfaces that allow the collection of impurities.

The rate of penetration into the metal by pitting may be 10 to 100 times greater than for general corrosion. Pitting occurs mostly in stagnant fluids.

Summary for Pitting Corrosion:

Typical Nuclear Plant Component Types - All typical fluid system components.

Susceptible Materials - All typical power plant materials except concrete.

Typical Nuclear Plant Fluids - Water in its liquid phase.

Effects of Aging - Pits, crack initiation.

Failure Modes - Seepage/leakage. 
For More Detailed Information - See References 4.10, page 434; 4.13, page 45; 4.15, pages $51,70,135$.

\subsubsection{Galvanic Corrosion}

Galvanic corrosion is an accelerated electrochemical corrosion that occurs when two dissimilar metals are in contact or adjacent to each other in an electrolyte. The electrical potential between the dissimilar metals produces a current flow through the electrolyte. When this happens, the less noble of the two metals becomes the anode and corrodes.

Most metals and alloys can react as either an anode or a cathode. Whether a particular material reacts as a cathode or an anode is determined from its relative position to the material it is in contact with or adjacent to (see Table 4-1, the galvanic series chart). The further apart two materials are on the chart, the greater the electrical potential, current flow, and the rate of corrosion of the anodic material.

Galvanic corrosion does not require oxygen but does require water or another conductive medium. Galvanic corrosion is usually localized in its attack. The resultant corrosion products also may cause stress to an adjacent component due to oxide wedging or formation of crevices. These stresses sometimes initiate other degradation mechanisms such as stress corrosion cracking.

The rate of galvanic corrosion is affected by the relative size of the dissimilar materials and composition of the electrolyte. A small anode area in contact with or adjacent to a large cathode area will result in rapid corrosion of the smaller anode. Conversely, a large anode area in contact with a small cathode area will lessen the rate of galvanic corrosion. Higher electrolyte conductivity results in higher rates of corrosion because there will be less resistance to electron flow.

Summary for Galvanic Corrosion:

Typical Nuclear Plant Component Types - All typical fluid system components.

Susceptible Materials - All typical power plant fluid system materials except concrete.

Typical Nuclear Plant Fluids - Good electrolytes such as water in its liquid phase.

Effects of Aging - Wall thinning, crack initiation, pitting.

Failure Modes - Seepage/leakage with the potential for rupture when high component stresses are present.

For More Detailed Information - See References 4.15, page 43; 4.18, pages 5, 14, 15. 


\subsubsection{Microbiologically Intluenced Corrosion (MIC) and Tuberculation}

MIC is characterized by the formation of microbial colonies and associated scale and debris on the surface of the metal or alloy. MIC can affect most materials, such as carbon steels, stainless steels, and nickel alloys. MIC produces pitted surfaces; however, these pits are usually covered by the microorganism deposits. On stainless steels, the deposits and pitting are usually found in the associated weld and heat-affected zones. The MIC deposits usually contain:

1. Large amounts of iron and manganese despite the type of alloy, or

2. Silicon, sulfur, and chloride, or

3. Phosphorus.

Many different organisms can cause MIC, depending on the alloy and the environmental conditions. However, recent studies have shown the following types to be the most damaging to power plant environments:

- deposit-forming iron and manganese bacteria

- the slime-forming Pseudomonas type of bacteria

- deposit-forming and iron-reducing bacillus type organisms

- sulfate-reducing bacteria

Temperature, pressure, $\mathrm{pH}$, water content, salinity, oxygen, and types and quantities of nutrients available are among the important factors influencing the presence of microbes.

Summary for MIC:

Typical Nuclear Plant Component Types - All typical fluid system components.

Susceptible Materials - All typical power plant fluid system materials except concrete.

Typical Nuclear Plant Fluids - Water in its liquid phase, fuel oils that contain water, and soils that allow water to concentrate on the external tank surface.

Effects of Aging - Pits, crevices, crack initiation.

Failure Modes - Seepage/leakage.

For More Detailed Information - See References 4.19; 4.12, page 161; 4.20, page 392; $4.21 ; 4.22$. 


\subsubsection{Stress Corrosion Cracking (SCC)}

SCC is the term given to subcritical crack growth in certain alloys when subjected to stress and a corrosive environment. Many alloys are susceptible to SCC; however, SCC does not occur in all environments, nor does an environment that produces SCC in one alloy necessarily produce SCC in other alloys.[4.23]

Three factors or conditions must be present simultaneously for SCC to occur. Elimination of or a reduction in one or a combination of these three factors will significantly reduce the likelihood of or eliminate SCC. The three factors are:

- Susceptible material

- Tensile stress (applied and/or residual)

- Corrosive environment

The following sections discuss the different types of SCC that have occurred in power plant environments.

\subsubsection{Intergranular Stress Corrosion Cracking (IGSCC)}

IGSCC occurs when carbide precipitation depletes the matrix of chromium adjacent to the grain boundary. The grain boundary then becomes anodically active and susceptible to corrosion. The corrosion rate increases markedly because the depleted grain boundary is much more susceptible to intergranular corrosion. Impurities in a metal can also segregate and produce an impure grain boundary. The effect of these impurities alters the corrosion and mechanical properties of the grain boundary and causes cracking by anode dissolution.

Summary for IGSCC:

Typical Nuclear Plant Component Types - All typical fluid system components.

Susceptible Materials - Inconel, copper alloys, non-cast austenitic stainless steel.

Typical Nuclear Plant Fluids - Water in its liquid phase.

Effects of Aging - Cracking.

Failure Modes - Seepage/leakage.

For More Detailed Information - See References $4.3 ; 4.24 ; 4.12 ; 4.25 ; 4.13$, page 45; $4.26 ; 4.27$.

\subsubsection{Transgranular Stress Corrosion Cracking (TGSCC)}

TGSCC differs from IGSCC in that the cracking occurs through or across the grain boundary as opposed to along the grain boundary. IGSCC and TGSCC often occur in the same 
alloy depending on the service environment, microstructure of the metal, or the applied or residual stress/strain state.

Summary for TGSCC:

Typical Nuclear Plant Component Types - All typical fluid system components.

Susceptible Materials - Aluminum alloys, copper alloys, non-cast austenitic stainless steel, and martensitic stainless steels.

Typical Nuclear Plant Fluids - Water in its liquid phase.

Effects of Aging - Cracking, seepage/leakage.

Failure Modes - Through wall cracks.

For More Detailed Information - See References 4.24; 4.8; 4.13, page 45; 4.16, pages $6-69,15-14 ; 4.27$, page 142 .

\subsubsection{Erosion/Corrosion}

Flowing fluids can remove protective oxide films in the right environment. This phenomenon is called erosion/corrosion $(\mathrm{E} / \mathrm{C})$ when it occurs in a single phase, pure water environment. The severity of $\mathrm{E} / \mathrm{C}$ is related to the material type, fluid temperature, fluid velocity, the geometry of the component, and the amount of dissolved oxygen in the fluid.

$\mathrm{E} / \mathrm{C}$ involves electrochemical aspects of general corrosion. However, in an $\mathrm{E} / \mathrm{C}$ process the metal forms an oxide layer, erosive action removes this oxide layer, and the exposed metal surface again corrodes. This action of oxide formation and removal leads to a reduction of component thickness. $\mathrm{E} / \mathrm{C}$ is usually found in very turbulent flow areas, and is characterized by a pattern of grooves aligned with the direction of flow.

Stainless steel and high alloy steels, which possess high corrosion resistance properties, are less susceptible to the effects of $\mathrm{E} / \mathrm{C}$ than other metals, such as plain carbon steel and copper alloys.

Summary for Erosion/Corrosion:

Typical Nuclear Plant Component Types - All typical fluid system components.

Susceptible Materials - Carbon steel, cast irons, low alloy steels, aluminum, concrete, and copper alloys.

Typical Nuclear Plant Fluids - Water in its liquid phase.

Effects of Aging - Wall thinning. 
Failure Modes - Seepage/leakage with the potential for rupture when high component stresses are present.

For More Detailed Information - See References $4.28 ; 4.2 ; 4.11 ; 4.29 ; 4.8 ; 4.13$, page $45 ; 4.15$, page 91 .

\subsubsection{Two-Phase Erosion}

Two-phase erosion, like E/C, is the physical loss of material due to the relative motion of the component and the process fluid. In two-phase erosion, a pressure increase causes the vapor portion to collapse, which causes higher velocities in the liquid phase. The accelerated liquid phase impinges on the metal, causing a quicker deterioration. Two-phase erosion also generally exhibits directional flow patterns.

Cavitation is another form of two-phase erosion. When the local pressure in a flowing liquid is reduced without a change in temperature, vapor-filled bubbles can form and expand within the flowing liquid. When these bubbles later pass into a region of higher pressure the bubbles collapse very rapidly and produce high, localized fluid velocities. This process is called cavitation. Cavitation causes damage to the oxide layer and underlying base metal. Cavitation is usually only experienced on pump impellers and ship propellers.

Summary for Two-Phase Erosion:

Typical Nuclear Plant Component Types - All typical fluid system components.

Susceptible Materials - Carbon steel, cast irons, low alloy steels, aluminum, copper alloys, concrete, and martensitic and ferritic stainless steels.

Typical Nuclear Plant Fluids - Wet steam or a two-phase (liquid and vapor) water.

Effects of Aging - Wall thinning, pitting, wastage of material.

Failure Modes - Seepage/leakage with the potential for rupture when high component stresses are present.

For More Detailed Information - See References 4.29; 4.15, page 19.

\subsubsection{Intergranular Attack}

Intergranular attack (IGA) results in localized corrosion at or near the grain boundaries. IGA can be caused by impurities, enrichment of one alloying element, or depletion of one alloying element in the grain boundary areas. IGA usually occurs in harsh acidic environments. Unlike SCC, no stress is needed for IGA to occur. Two specific types of aging mechanisms are grouped in the IGA category. They are weld decay and knifeline attack.

Weld decay occurs in non-stabilized, sensitized austenitic stainless steel. When an austenitic stainless steel with moderate carbon content is heated between $425^{\circ} \mathrm{C}$ and $815^{\circ} \mathrm{C}$ 
[ $800^{\circ} \mathrm{F}$ to $1500^{\circ} \mathrm{F}$ ], the dissolved carbon migrates to the grain boundaries and precipitates as chromium carbides. This leaves a chromium depleted zone with diminished corrosion resistance around each grain. Because the grains have less corrosion resistance, exposure to harsh, acid process fluids can result in IGA of the material. Lowering the material's carbon content reduces the likelihood of weld decay.

In order to combat the effects of weld decay, metallurgists have added titanium, columbium, or columbium-tantalum mixtures to permit the alloy to precipitate titanium or columbium carbides and leave the chromium in place. These new alloys (i.e., type 347 ) were called stabilized steels.

Two problems existed with this approach. First, the titanium did not transfer well across a welding arc, making the material harder to weld. Second, although the use of columbium did not produce welding difficulties, it did redissolve upon multiple pass welding, allowing the chromium and carbon precipitates to form in the welds fusion zone, producing a highly localized attack called knifeline attack.

Summary for Intergranular Attack:

Typical Nuclear Plant Component Types - All typical fluid system components.

Susceptible Materials - Inconel and austenitic stainless steel.

Typical Nuclear Plant Fluids - Acid water-based fluids.

Effects of Aging - Cracking.

Failure Modes - Seepage/leakage.

For More Detailed Information - See References 4.30; 4.8; 4.13, pages 63-64; 4.15, page $78 ; 4.16$, page $15-13$.

\subsubsection{Hydrogen Damage}

Hydrogen damage is a general term which refers to mechanical damage of a metal caused by the presence of, or interaction with, hydrogen. Hydrogen damage may be classified into four distinct types:[4.14]

1. Hydrogen blistering

2. Hydrogen embrittlement

3. Decarburization

4. Hydrogen attack 
Hydrogen blistering occurs because of hydrogen evolution, due to corrosion, which diffuses into the metal rather than forming molecules. Much of the hydrogen continues to diffuse through the steel and combines to form molecules on the exterior surface of the component. However, if hydrogen molecules diffuse into a void in the metal (such as found in rimmed steels), they could combine and form molecules in the void. Since molecular hydrogen cannot diffuse, the hydrogen pressure in the void can increase and rupture or blister the material. Hydrogen blistering is most prevalent in the petroleum industry. It occurs in storage tanks and in the refining processes. Minimizing the corrosion rate and using steels with little or no voids are the best methods to prevent hydrogen blistering.

The exact mechanism for hydrogen embrittlement is not as well known as that of hydrogen blistering. However, the initial cause is the same: the penetration of atomic hydrogen into the metal structure.

Most of the proposed mechanisms for hydrogen embrittlement are based on the slip interference by dissolved hydrogen, which decreases the materials ductility and causes cracking with the potential for rupture. This mechanism is sometimes called hydrogen stress cracking. It occurs in higher strength alloys, where the environment is corrosive, and when the operating temperature is lower than $65^{\circ} \mathrm{C}\left[150^{\circ} \mathrm{F}\right]$. It can be prevented by eliminating or reducing the corrosive environment (e.g., inhibitors) and adding nickel or molybdenum to reduce susceptibility.

Decarburization is another effect that high-temperature hydrogen gas can have on a metal. If the alloy is strengthened by interstitial carbon or by carbide precipitates, decarburization results in a reduction of tensile strength and an increase in ductility and creep rate. The reverse process carburization, or hydrogen attack, also can occur in hydrogen-hydrocarbon gas mixtures frequently encountered in petroleum-refining operations. Both of these aging mechanisms require exposure to high temperature gas $\left(>200^{\circ} \mathrm{C}\left[390^{\circ} \mathrm{F}\right]\right)$.

Hydrogen damage is not a concern unless the tank has cathode protection and the voltage is set improperly. Hydrogen damage is normally only a concern in the petroleum refining industry.

Summary for Hydrogen Damage:

Typical Nuclear Plant Component Types - All typical fluid system components.

Susceptible Materials - Titanium, carbon and low alloy steels, cast iron, and ferritic and martensitic stainless steels.

Typical Nuclear Plant Fluids - Corrosive fluids.

Effects of Aging - Blistering, cracking, reduction or increase in tensile strength.

Failure Modes - Seepage/leakage with the potential for rupture when high component stresses are present. 
For More Detailed Information - See References 4.12; 4.13, pages 45, 229; 4.15, pages 143-147, 247; 4.16, pages 4-82; 4.27.

\subsubsection{Pool Structural Component Aging}

The supporting structure for fuel pool liner plates, both wall and floor plates, is a reinforced concrete material system. This concrete material system can degrade over time, causing it to be ineffective in supporting the liner plate. This degradation can occur from a combination of aggressive chemical attack or corrosion of embedded steel/rebar. It should be noted that these mechanisms occur primarily as a result of the liner plate failure, which allows the concrete and associated embedded steel to be exposed to borated water, which initiates the degradation. Liner plate aging mechanisms are the same as those of tanks, so they will not be addressed further. Reference 4.31 also discusses the integrity of metallic spent fuel pool components.

\subsubsection{Aggressive Chemical Attack}

Concrete, being highly alkaline $(\mathrm{pH}>12.5)$, is vulnerable to degradation by strong acids. Acid attack can increase porosity and permeability of concrete, reduce its alkaline nature at the surface of the attack, reduce strength, and render the concrete subject to further deterioration. Portland cement concrete is not acid-resistant, although varying degrees of resistance can be achieved depending on the materials used and the attention to placing, consolidating, and curing. No portland cement concrete, regardless of its composition, will withstand exposure to highly acidic fluids for long periods.

A dense concrete with low permeability may provide an acceptable degree of protection against mild acid attack. Any factors that tend to improve the compressive strength of the concrete will have a beneficial effect on low permeability. Therefore, the better the quality of the constituent material, the less permeable the concrete. Low water-to-cement ratio, smaller aggregate, long curing period, entrained air, and thorough consolidation all contribute to watertightness.

Concrete thus constructed has a low permeability and effective protection against sulfate and chloride attack. Minimum degradation threshold limits for concrete have been established at $500 \mathrm{ppm}$ chloride or $1,500 \mathrm{ppm}$ sulfates. The use of an appropriate cement type (e.g., ASTM C150, Type II) and pozzolan (e.g., fly ash) also increases sulfate resistance.

Summary for Aggressive Chemicals:

Typical Nuclear Plant Component Types - Steel-lined reinforced concrete pools.

Susceptible Materials - Concrete.

Typical Nuclear Plant Fluids - Borated water.

Effects of Aging - Cracking, loss of material. 
Failure Modes - Concrete deterioration as a result of a liner plate failure.

For More Detailed Information - See Reference 4.9.

\subsubsection{Corrosion of Embedded Steel/Rebar}

Concrete's high alkalinity $(\mathrm{pH}>12.5)$ provides an environment around embedded steel/rebar and protects them from corrosion. If the $\mathrm{pH}$ is lowered (e.g., 10 or less), corrosion may occur. However, the corrosion rate is still insignificant until a $\mathrm{pH}$ of 4.0 is reached. A reduction in $\mathrm{pH}$ can be caused by the leaching of alkaline products through cracks, the entry of acidic materials, or carbonation. Chlorides can be present in constituent materials of the original concrete mix (i.e., cement, aggregates, admixtures, and water), or they may be introduced environmentally. The severity of corrosion is influenced by the properties and type of cement and aggregates as well as the concrete moisture content.

Corrosion products have a volume greater than the original metal. The presence of corrosion products on embedded steel or rebar subjects the concrete to tensile stress that eventually causes hairline cracking, rust staining, spalling, and more severe cracking. These actions will expose more embedded steel/rebar to a potentially corrosive environment and cause further deterioration in the concrete. A loss of bond between the concrete and embedded steel/rebar will eventually occur, along with a reduction in steel cross section. Rebar corrosion can cause deterioration of concrete from a series of hairline cracking, rust staining, spalling, and more severe cracking. These conditions can ultimately impair structural integrity.

The degree to which concrete provides satisfactory protection for embedded steel/rebar depends in most instances on the quality of the concrete and the depth of concrete cover over the steel. The permeability of the concrete is also a major factor affecting corrosion resistance. Concrete of low permeability contains less water under a given exposure, and hence is more likely to have lower electrical conductivity and better resistance to corrosion. Such concrete also resists absorption of salts and their penetration into the embedded steel and provides a barrier to oxygen, an essential element of the corrosion process. Low water-to-cement ratios and adequate air entrainment increase resistance to water penetration and thereby provide greater resistance to corrosion.

Summary for Corrosion of Embedded Steel/Rebar:

Typical Nuclear Plant Component Types - Steel-lined reinforced concrete pools.

Susceptible Materials - Embedded steel/rebar.

Typical Nuclear Plant Fluids - Borated water.

Effects of Aging - Loss of material.

Failure Modes - Concrete deterioration as a result of a liner plate failure and embedded steel/rebar corrosion. 
For More Detailed Information - See Reference 4.9.

\subsection{Aging Mechanism Significance}

All aging mechanisms that could apply to tanks and pools were described in Section 4.2 and Appendix E. However, several of these mechanisms are not significant to tanks and pools components. Sections 4.3.1 and 4.3.2 evaluate significant and non-significant aging mechanisms, respectively.

\subsubsection{Significant Aging Mechanisms}

This section describes the evaluation process used to identify those aging mechanisms considered significant for tanks and pools and identifies the methodology and key decision parameters developed for the potentially significant aging mechanisms listed in Table 4-2.

A search was conducted through industry documents to gain a better understanding of each mechanism. The search produced a list of documents that were helpful in predicting the potential for degradation of important tank/pool components in a nuclear power plant. These documents are listed in Section 4.5 of this report. This review also served to verify the applicability of the potentially significant aging mechanisms listed in Table 4-2.

\subsubsection{Key Decision Parameters}

A key decision parameter is a material or environmental characteristic that by itself or with other key decision parameters provides definite exclusion or definite inclusion of potential aging mechanisms. The material aging analysis diagrams for carbon steel and stainless steel shown in Figures 4-1 and 4-2 and Table 4-4 summarize the key decision parameters deemed important to the prediction of tank and pool component degradation.

A thorough review of the references listed in Section 4.5 resulted in identification of the key decision parameter screening values for each aging mechanism. Therefore, this report is primarily a summary of those references. Where the key decision parameter screening values were not definitively given in the references, taking an appropriately conservative view of the aging mechanism allowed an assignment of these values. These conservative assignments are identified as assumptions on the material aging analysis diagrams contained in Figures 4-1 and 4-2. Assumptions are listed in Section 4.3.2. (Note: In Figures 4-1 and 4-2, various references are listed without the section number prefix; e.g., "17 page 161" in Figure 4-1A means Reference 4.17, page 161, and "a1" designates assumption 1, Section 4.3.1.2.1.)

The logic diagrams provide a consistent method of handling the wide range of materials and environmental conditions that exist in a nuclear plant fluid system. Each question on the logic diagrams identifies one or more key decision parameters and their applicable screening values along with the applicable references and assumptions. Because of the large number of aging mechanisms evaluated, only those deemed potentially significant are included in Figures 4-1 and 4-2. 
Table 4-4. Aging Mechanism Key Decision Parameters

\begin{tabular}{|c|c|}
\hline Environmental Parameters & Material Parameters \\
\hline $\begin{array}{l}\qquad \underline{\text { Inside }} \\
\\
\text { Process Fluid Type } \\
\text { System Treated for MIC } \\
\text { Chemicals Added } \\
\text { Fluid Velocity } \\
\text { Stagnant Flow Conditions } \\
\text { Fluid pH Range } \\
\text { Potential for Impurity } \\
\text { Operating Temperature } \\
\text { Operating Pressure } \\
\text { Saturation Pressure } \\
\text { Fluid Content: } \\
\quad \text { Chloride } \\
\text { Chromate } \\
\text { Fluoride } \\
\text { Oxygen } \\
\text { Protective Coating } \\
\quad \text { Outside } \\
\text { Buried } \\
\text { Insulated } \\
\text { Located Outside } \\
\text { Cathodic Protection Used } \\
\text { Lifetime Neutron Exposure } \\
\text { Protective Coatings }\end{array}$ & $\begin{array}{l}\quad \text { Material } \\
\text { Clad } \\
\text { Classification } \\
\text { Grade } \\
\text { Hardness } \\
\text { Heat Treatment } \\
\text { Solution Treatment } \\
\text { Type } \\
\text { Yield Strength } \\
\qquad \quad \text { Material Content } \\
\text { Aluminum } \\
\text { Antimony } \\
\text { Arsenic } \\
\text { Carbon } \\
\text { Chromium } \\
\text { Copper } \\
\text { Ferrite } \\
\text { Manganese } \\
\text { Molybdenum } \\
\text { Nickel } \\
\text { Phosphorus } \\
\text { Silicon } \\
\text { Tin } \\
\text { Zinc }\end{array}$ \\
\hline
\end{tabular}

The diagrams can be used to determine the potential for corrosion caused by outside environmental factors and corrosion caused by the process fluids. To obtain valid results, and to fully understand why there is or is not a concern for a particular degradation mechanism, the following steps must be completed in order: 
1) Start at the beginning of the diagram and answer each question before proceeding to the next question.

2) If a concern is identified, write it down before proceeding with the next question.

3) Complete the entire diagram before attempting to summarize the degradation concerns for a tank.

When using Figures 4-1 and 4-2, note that Figures 4-1A and 4-2A apply to external surfaces, and the remaining parts apply to internal surfaces.

As an example, suppose you want to evaluate an in-ground diesel fuel oil tank. As you proceed through the diagram, you may determine early on that external crevice pitting corrosion is a concern because the tank is buried (this would represent an outside environmental factor). Further on in the diagram, however, because of the process fluid type, you determine that internal crevice pitting corrosion is not a concern. It is important to stress that once one mechanism has been determined to be a concern, that concern cannot be "overturned" by an evaluation done later in the diagram. Therefore, in this case, external crevice pitting corrosion is a potentially significant aging mechanism but internal crevice pitting corrosion is not.

An even better way to document your evaluation, other than writing down the degradation mechanisms that are a concern, is to make a copy of the diagram, and mark the paths that were taken to reach your conclusions. You can then circle those conclusions that require more scrutiny or work.

Development of the logic diagrams consisted of completing the following tasks for each different material:

1. Identify the questions to be asked in order to reach conclusions.

2. Determine the order in which the questions should be asked. The order is based on a prioritization of the key decision parameters. Their prioritization is based upon:

a. Most readily available information first,

b. The key decision parameter's ability to singularly provide a conclusion, and

c. The key decision parameter's dependence on the values of other key decision parameters.

3. Ensure that each question answered "YES" or "NO" directs the evaluator to the appropriate conclusion.

4. Ensure that each key decision parameter screening value lists a reference and any assumptions used in its development. 
5. Ensure that for each material classification the twelve different process fluid types are properly covered on the aging analysis diagram.

The conclusions that can be reached on the material aging analysis diagrams are described below:

No - Aging mechanism does not significantly impact component reliability.

Yes - Aging mechanism may significantly impact component reliability.

\subsubsection{Assumptions Used to Develop Aging Analysis Diagrams}

Listed below are the assumptions made in the aging analysis diagrams. These assumptions were used only when the references provided generalized rather than the specific information needed to address a degradation issue. When assumptions are used in the diagrams they are identified as follows: (a1, a2), where the "a" signifies an assumption and the number following the "a" signifies the specific assumption in the lists that follow by material type.

\subsection{Austenitic Stainless Steel Aging Analysis Assumptions}

1. All buried fluid components (except titanium and concrete) are susceptible to MIC (References 4.20 and 4.21).

2. Systems containing clean water and fluids derived from clean water (steam systems) will not experience MIC. Plant operating practices provide the basis for this assumption.

3. Process fluids that normally do not contain moisture will not support MIC organisms.

4. As with other corrosion processes, TGSCC is not likely without a good conducting electrolyte (Reference 4.13, page 45).

5. Since the production of steam is a purifying process (water vapors form without impurities), IGA is not likely in a steam system (Reference 4.16, page 15-13).

6. As with other corrosion processes, IGA is not likely without a good conducting electrolyte (Reference 4.13, page 45).

7. Since most of the laboratory tests use acids to determine if IGA is a concern (Reference 4.30, page 187), an assumption can be made that the mechanism is partially based on exposure to acidic pHs.

8. References 4.15 and 4.18 identify the galvanic series for typical metals. It is assumed that although some galvanic potential exists with an immediately adjacent material, the effect is small in high quality, monitored process fluids. 
Note: This figure applies to external surfaces.

Note: Refer to Section 4.3.1.1 for instructions.

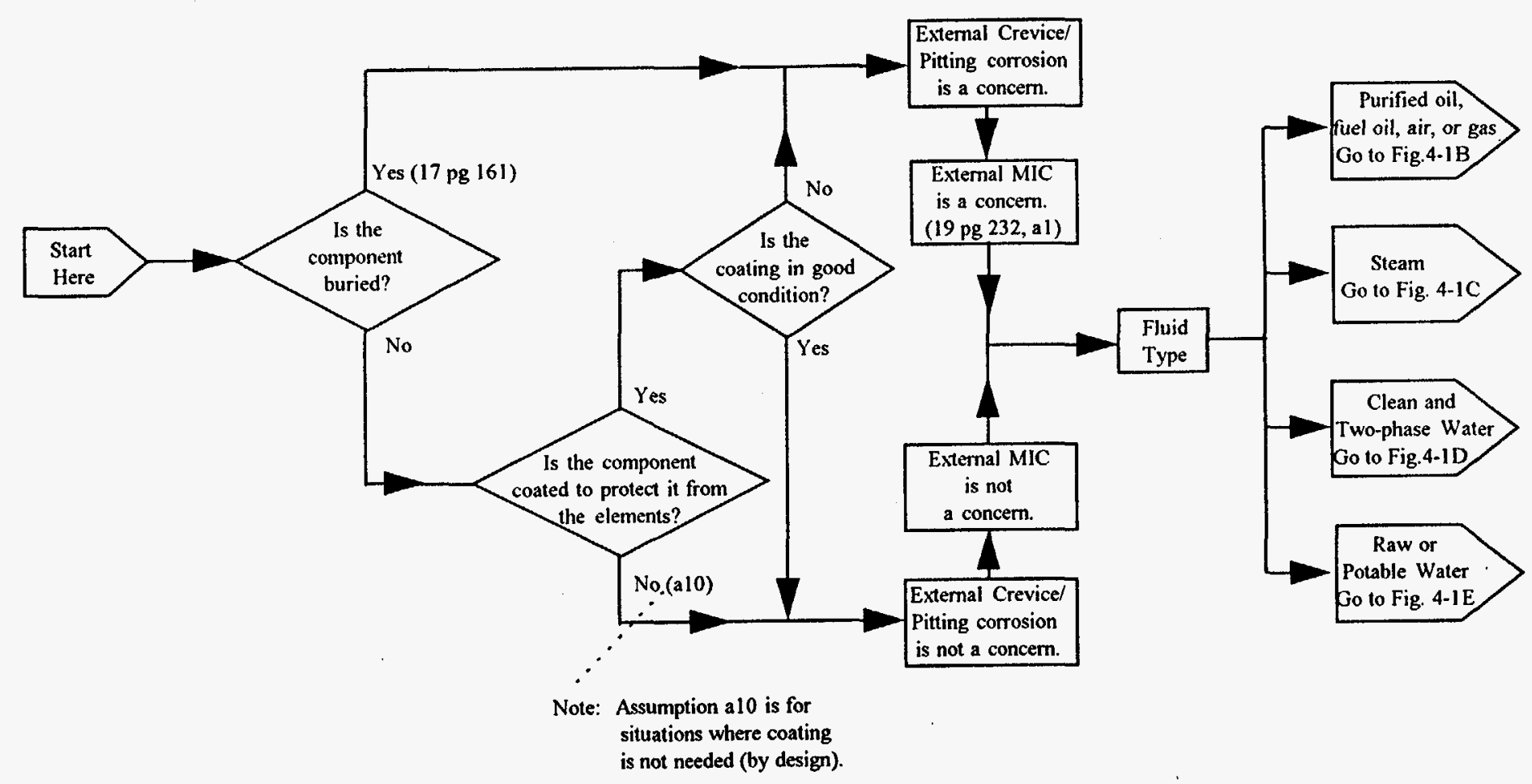

Figure 4-1A. Tank and Pool Austenitic Stainless Steel Aging Analysis Diagram. 
Note: This figure applies to internal surfaces.

Note: Refer to Section 4.3.1.1

for instructions.

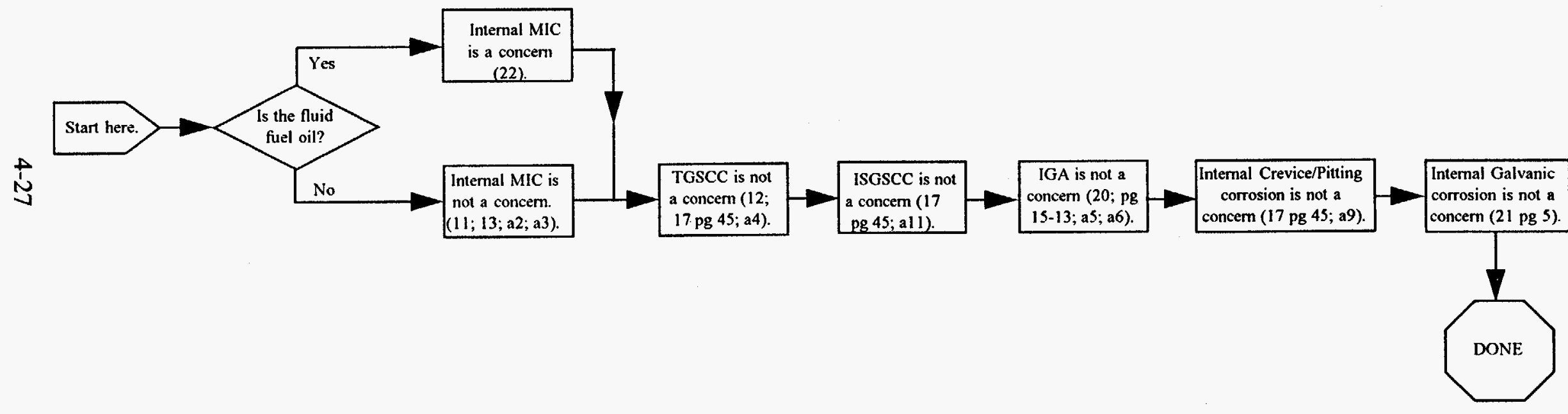

Figure 4-1B. Tank and Pool Austenitic Stainless Steel Aging Analysis Diagram Fluid Types: Air, Gas, Purified Oil, and Fuel Oil. 
Note: This figure applies to

internal surfaces.

Note: Refer to Section 4.3.1.1

for instructions.

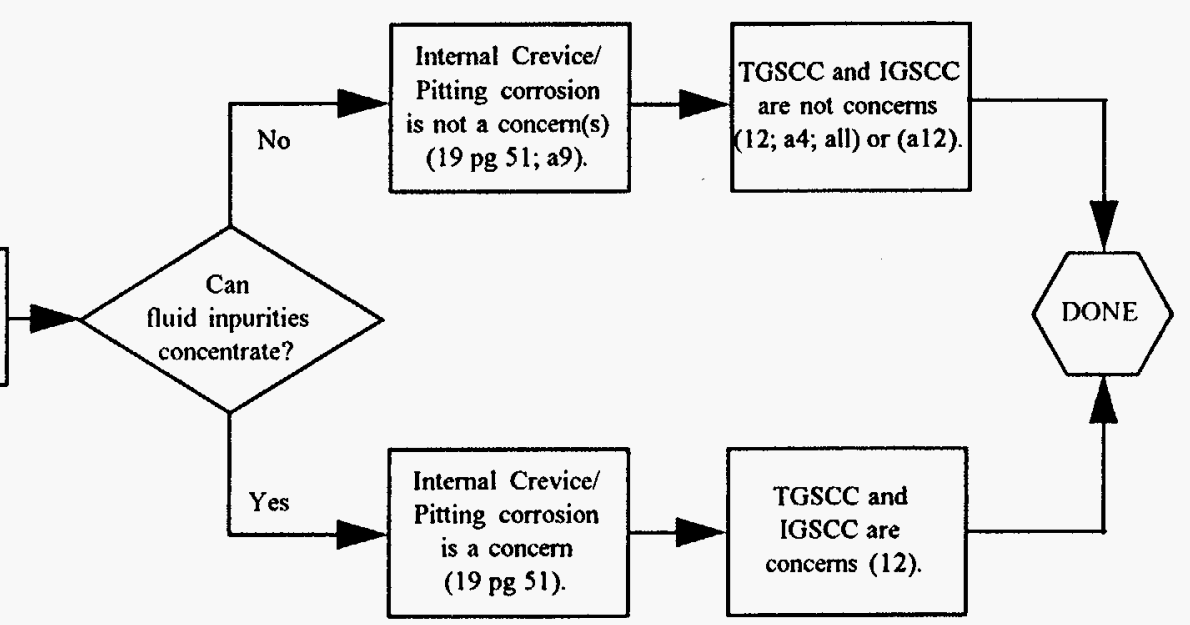

Figure 4-1C. Tank and Pool Austenitic Stainless Steel Aging Analysis Diagram Fluid Type: Steam. 


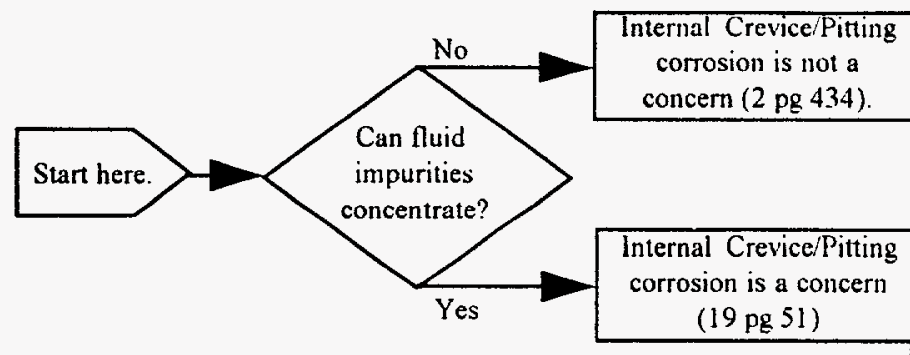

Note: This figure applies to internal surfaces.

Note: Refer to Section 4.3.1.1 for instructions.

Figure 4-1D. Tank and Pool Austenitic Stainless Steel Aging Analysis Diagram

Fluid Types: Clean Water and Two Phase

Sheet 1 of 2

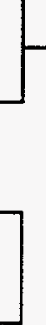
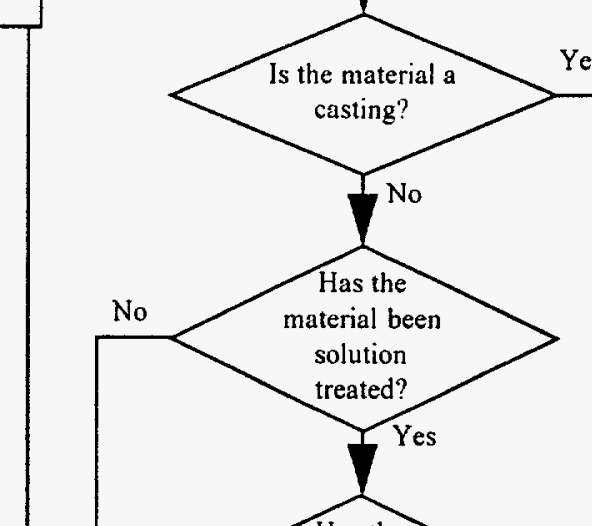

material been
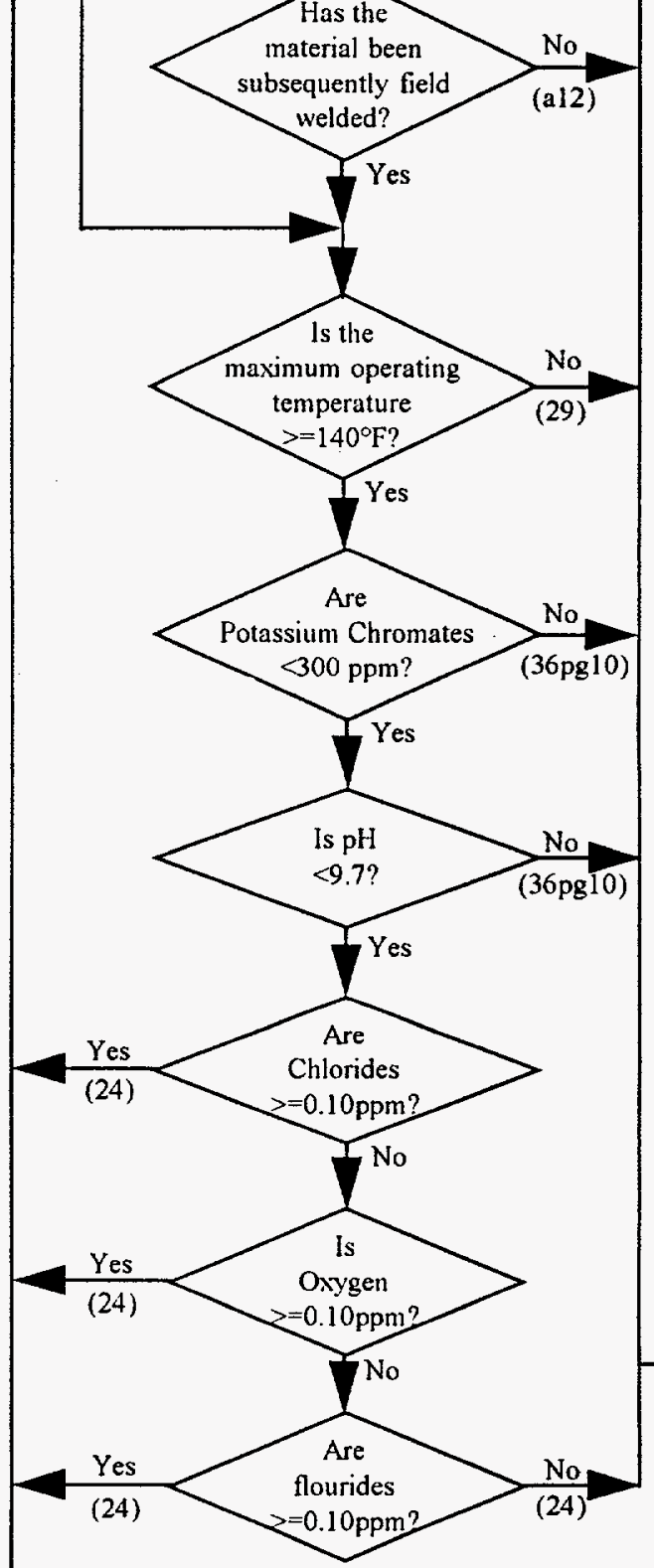

TGSCC and IGSCC are not concerns.

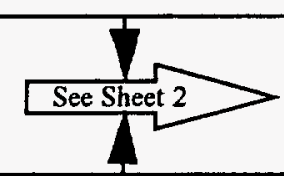




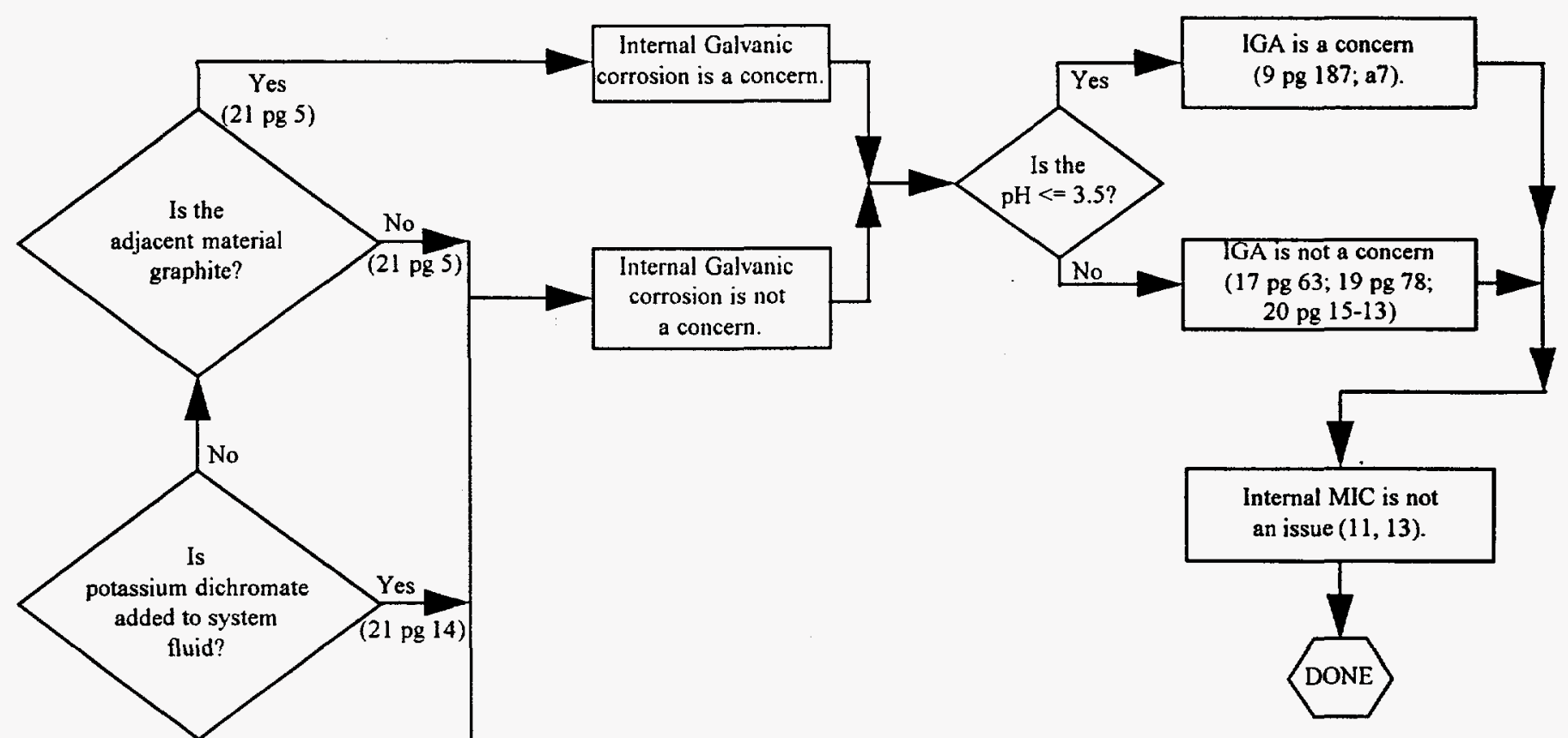

Note: This figure applies to internal surfaces.

Note: Refer to Section 4.3.1.1 for instructions.

Figure 4-1D. Tank and Pool Austenitic Stainless Steel Aging Analysis Diagram

\author{
Fluid Types: Clean Water \\ and Two Phase
}

Sheet 2 of 2 


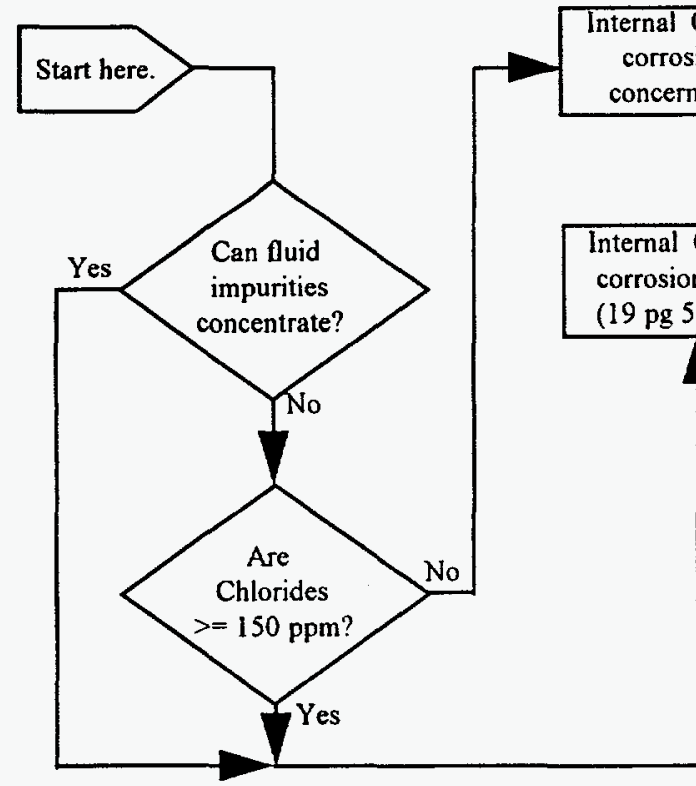

Note: This figure applies to internal surfaces.

Note: Refer to Section 4.3.1.1 for instructions.

Figure 4-1E. Tank and Pool Austenitic Stainless Steel Aging Analysis Diagram

Fluid Types: Raw and Potable Water

Sheet 1 of 2 


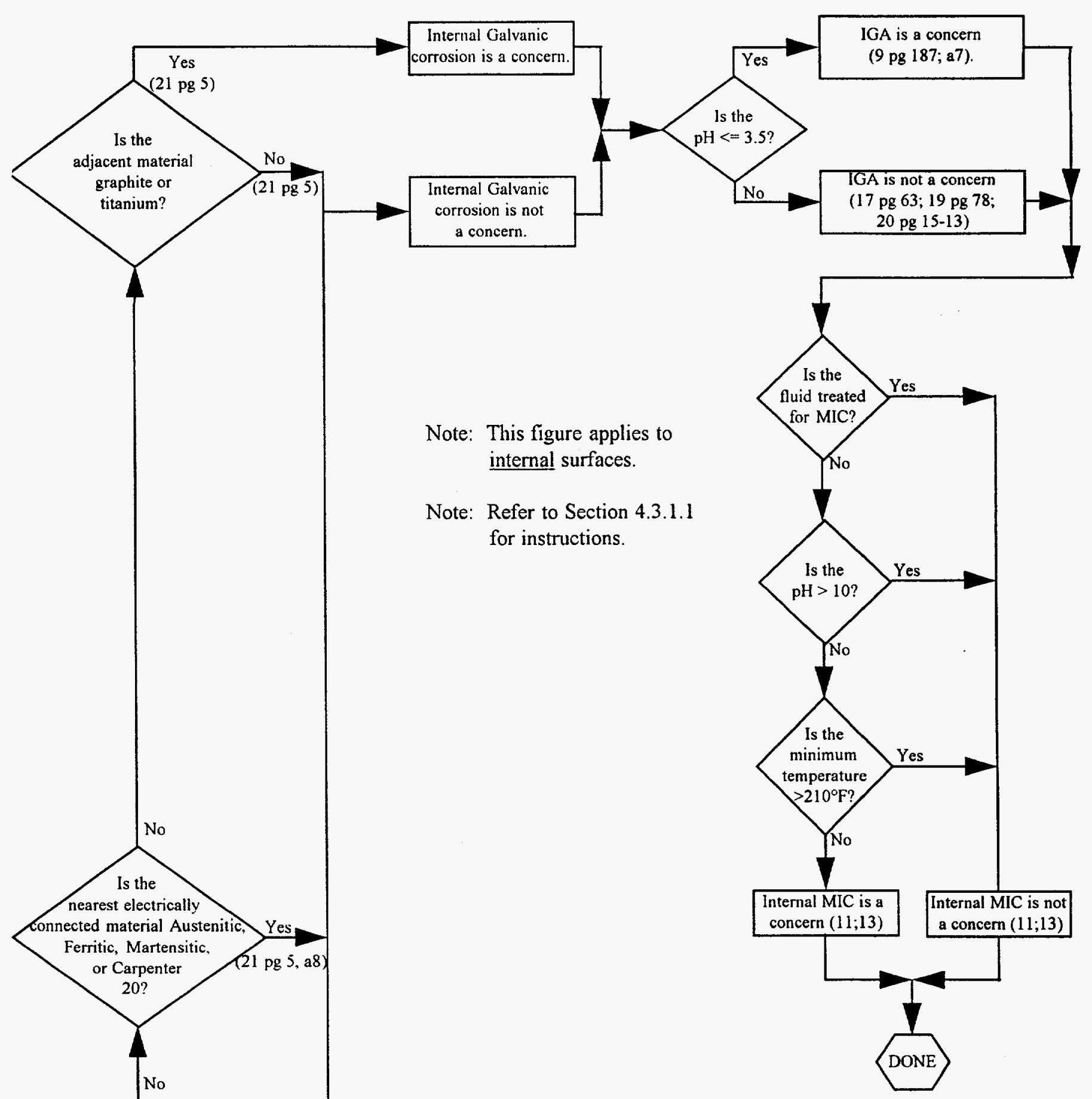

Figure 4-1E. Tank and Pool Austenitic

Is the nearest electrically connected material a phenolic, non-metallic, or concrete?

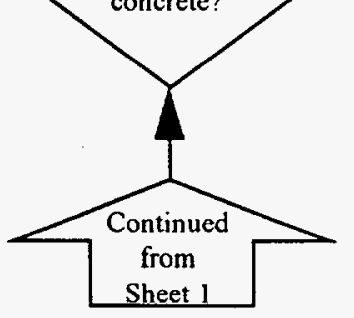

Stainless Steel Aging Analysis Diagram

\author{
Fluid Types: Raw and \\ Potable Water
}


Note: This figure applies to external surfaces.

Note: Refer to Section 4.3.1.1 for instructions.
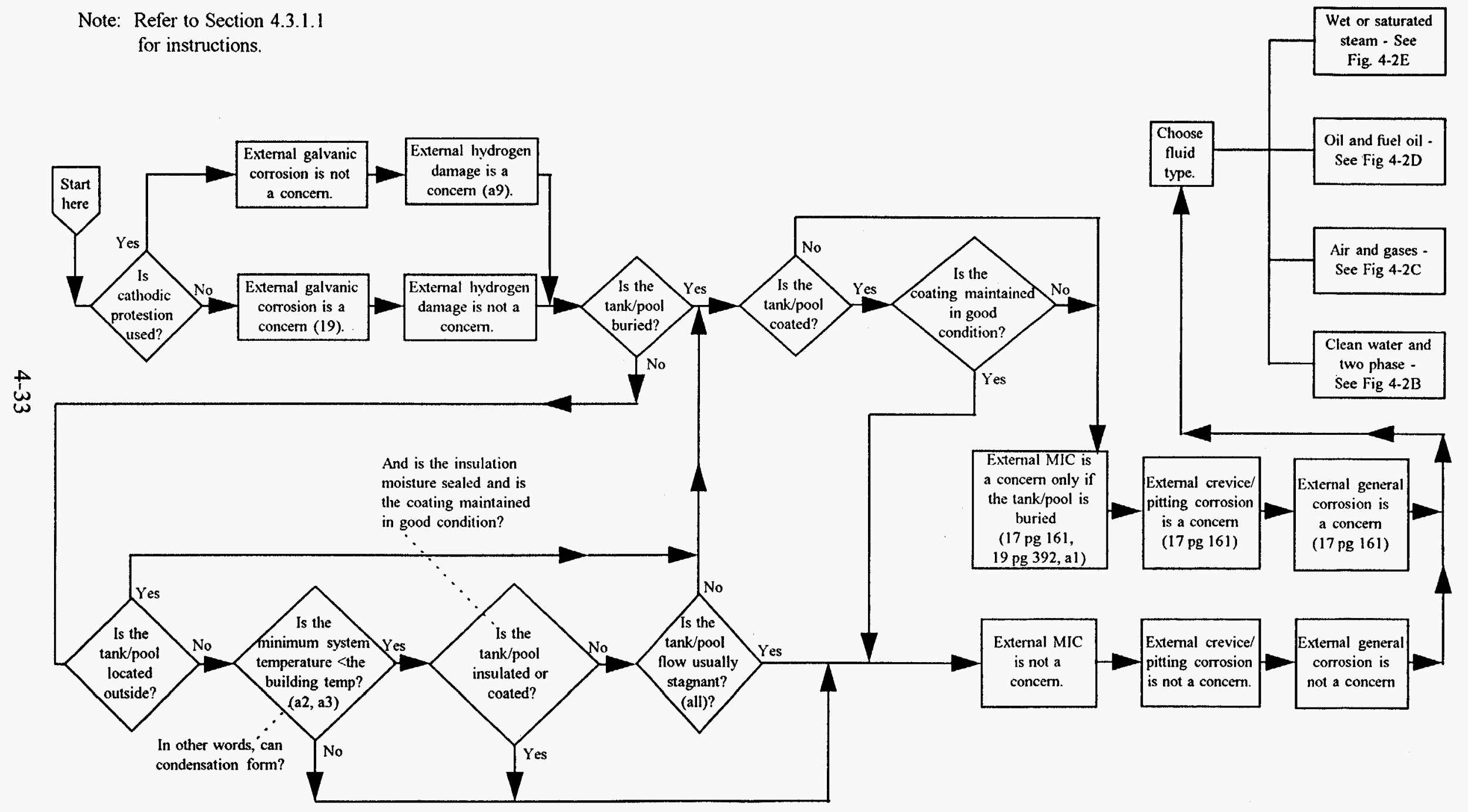

Figure 4-2A. Carbon Steel Tank and Pool Aging Analysis Diagram 
Figure 4-2B. Carbon Steel Tank and Pool Aging Analysis Diagram

Fluid Types: Clean Water and Two-Phase.

Page 1 of 2

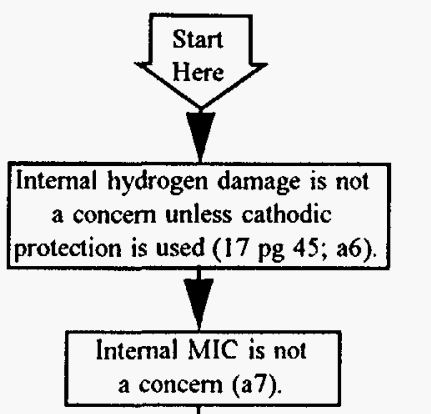

Note: This figure applies to internal surfaces.

Note: Refer to Section 4.3.1.1 $\stackrel{+}{\dot{\phi}}$ for instructions.

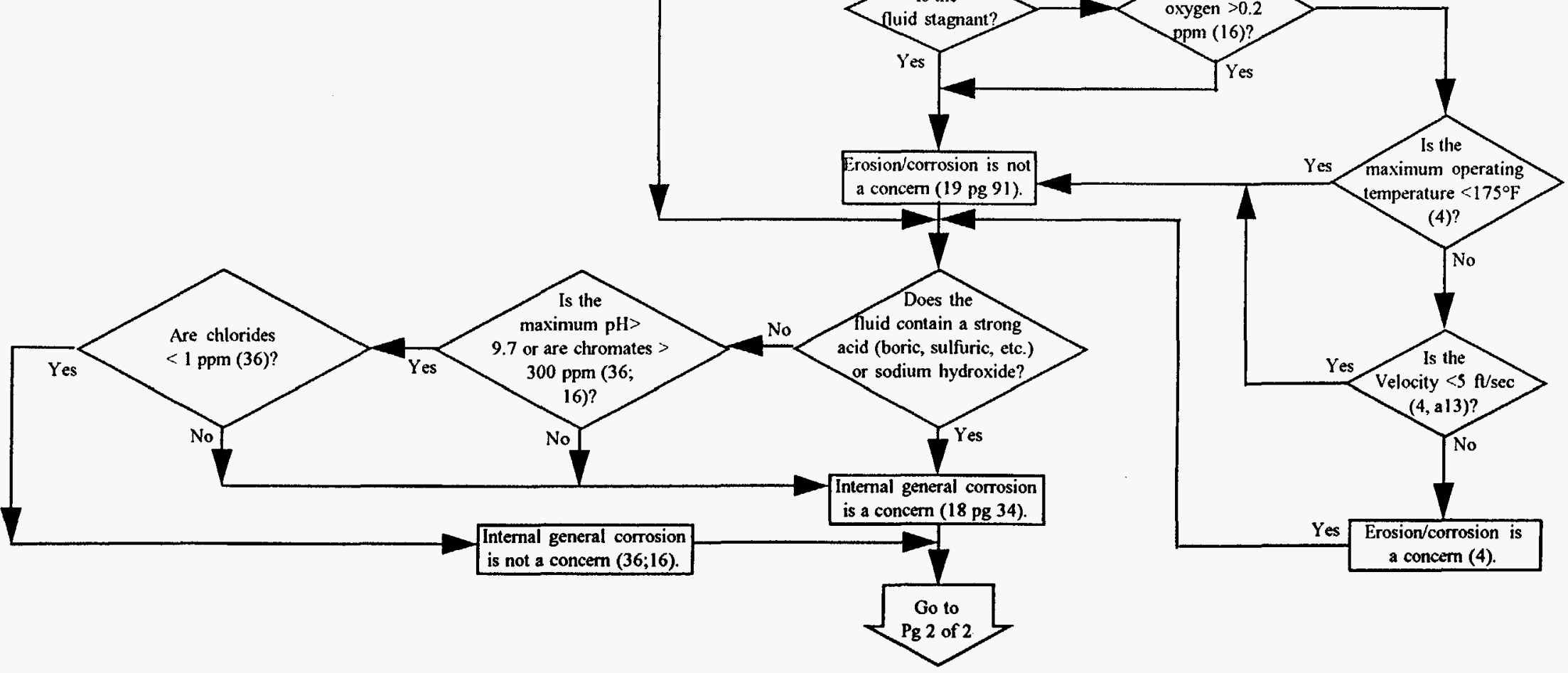


Figure 4-2B. Carbon Steel Tank and Pool Aging Analysis Diagram

Fluid Types: Clean Water and Two-Phase.

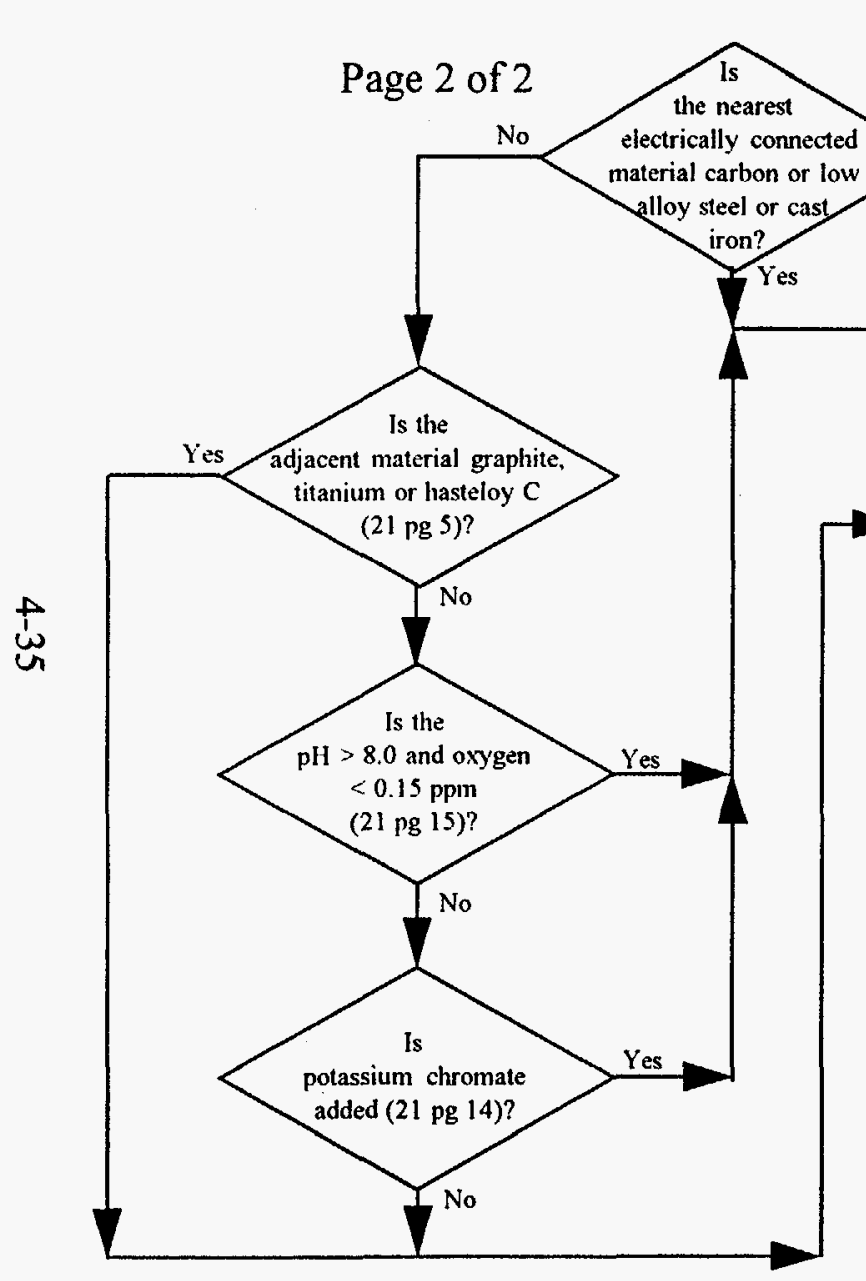

Note: This figure applies to internal surfaces.

Note: Refer to Section 4.3.1.1 for instructions. 
Note: This figure applies to internal surfaces.

Note: Refer to Section 4.3.1.1 for instructions.

Figure 4-2C. Carbon Steel Tank and Pool Aging Analysis Diagram

Fluid is a Gas

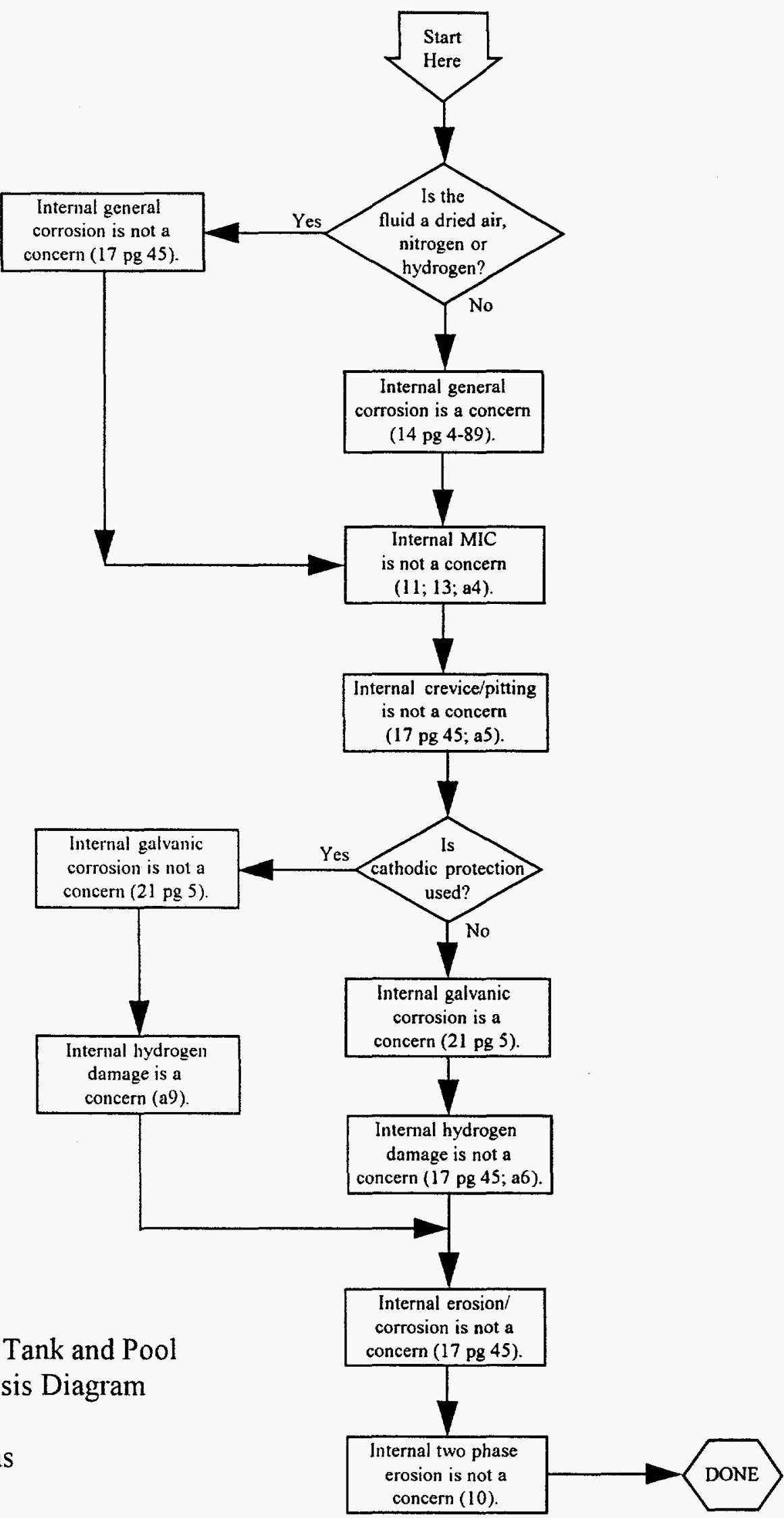


Note: This figure applies to internal surfaces

Note: Refer to Section 4.3.1.1 for instructions.

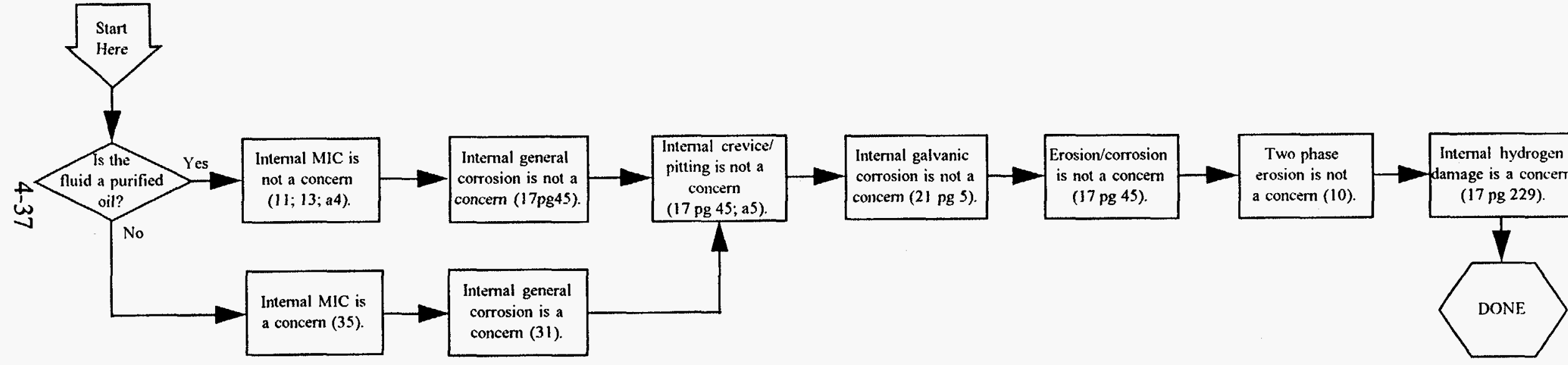

Figure 4-2D. Carbon Steel Tank and Pool Aging Analysis Diagram

Fluid Types: Oil and Fuel Oil 
Figure 4-2E. Carbon Steel Tank and Pool Aging Analysis Diagram

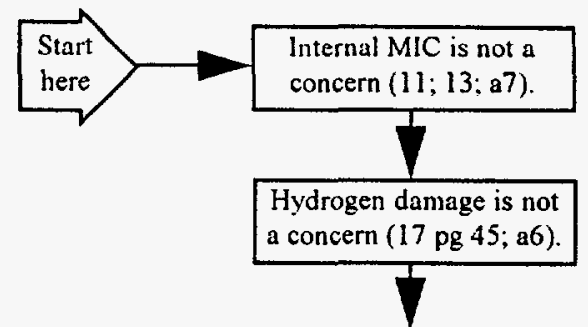

Fluid Types: Wet and

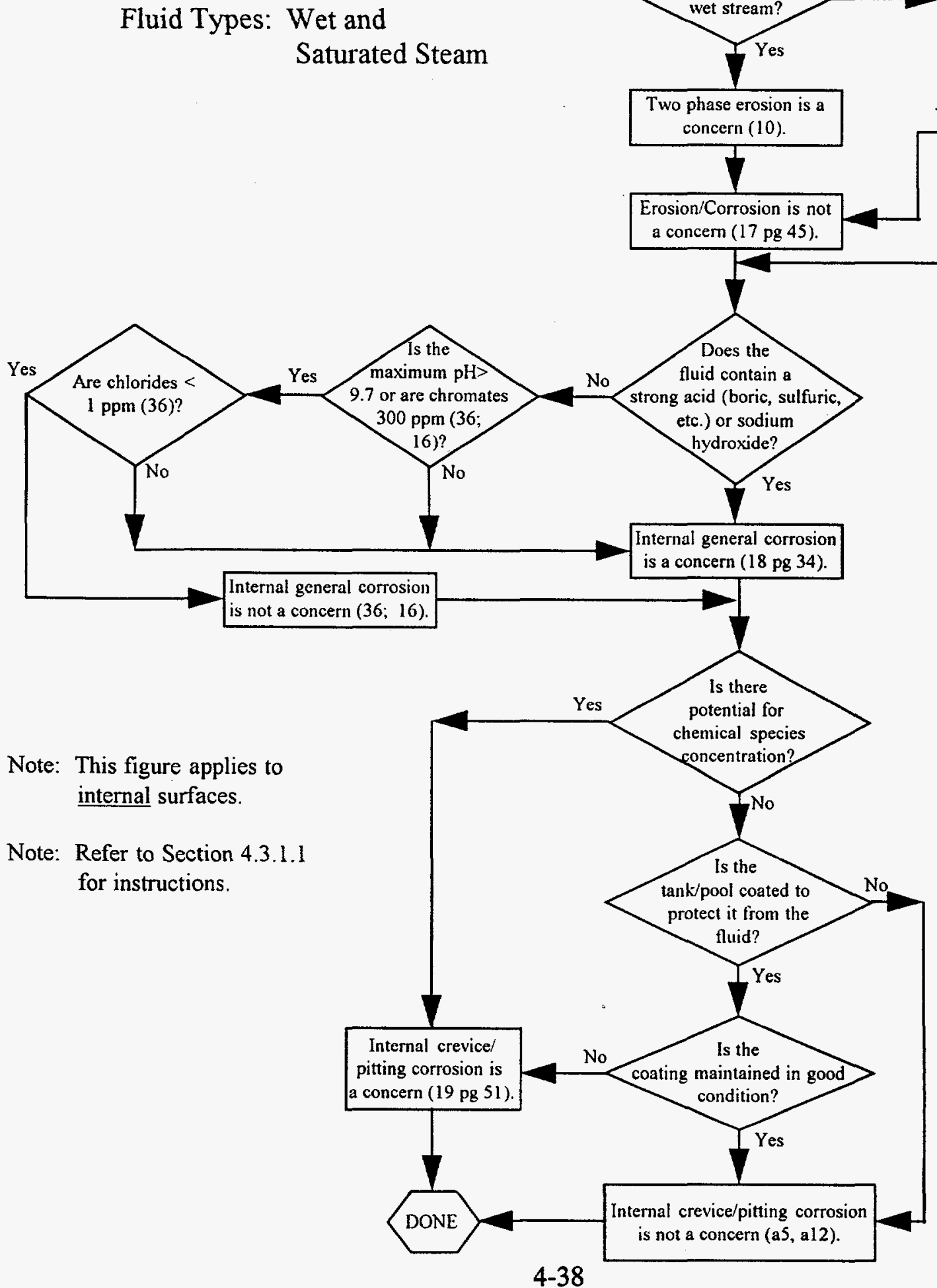

Erosion/Corrosion is a concern. 
9. As with other corrosion processes, crevice/pitting corrosion is not likely without a good conducting electrolyte (Reference 4.13, page 45).

10. Assumes component is not in a harsh environment that would have required a coating, i.e., there is no coating by design.

11. As with all other corrosion processes, IGSCC is not likely without a good conducting electrolyte (Reference 4.13 , page 45 ).

12. If the austenitic stainless steel was solution annealed, it is assumed to have been done after shop welding. Therefore, only field welding could change the properties developed by solution annealing the material.

\subsection{Carbon Steel Aging Analysis Assumptions}

1. Buried components (except titanium and concrete) are potentially affected by MIC (References 4.14 and 4.32).

2. Thermal insulation systems may allow the intrusion of moisture. Therefore, insulated components are subject to general corrosion under the insulation unless insulation is sealed to prevent moisture intrusion.

3. Relative humidity is assumed to be $100 \%$, and the dew point temperature is equivalent to the building temperature.

4. Fluids that do not contain moisture will not support long-term MIC colonies (Reference 4.12).

5. Crevice/pitting corrosion is not likely without a conducting electrolyte (Reference 4.18, page 45).

6. Hydrogen damage/embrittlement is only significant in harsh, corrosive environments. It also may be significant when lubricating fluids have corrosive chemical additives (Reference 4.15, page 66).

7. Systems containing clean water and fluids derived from clean water (steam systems) will not experience MIC. Plant operating practices and procedures provide the basis for this assumption.

8. If saturation pressure is within $5 \%$ of operating pressure, the fluid should be considered two-phase.

9. Cathodic protection can cause hydrogen damage/embrittlement when the voltage potential is not set properly. [This suggests the voltage should be periodically checked.] 
10. References 4.20 and 4.22 identify the galvanic series for typical metals, and provide guidance for determining the potential for galvanic corrosion. It is assumed that although some galvanic potential exists with an immediately adjacent material (see Table 4-1), the effect is insignificant in monitored process fluids.

11. If fluid is stagnant, the tank and surrounding environment will reach equilibrium and there will be no condensation.

12. Assumes component is not in a harsh environment that would have required a coating, i.e., there is no coating by design.

\subsubsection{Non-Significant Aging Mechanisms}

A nuclear plant operating environment does not support the existence of all the mechanisms listed in Tables 4-2 and 4-3. For example, material creep will not occur at operating temperatures less than $370^{\circ} \mathrm{C}\left[700^{\circ} \mathrm{F}\right]$ for carbon steel and the threshold is even higher for stainless steels. [4.33] Since the highest operating temperatures at a typical nuclear power station do not exceed $350^{\circ} \mathrm{C}\left[660^{\circ} \mathrm{F}\right]$, material creep is not a concern. In addition, some of the aging mechanisms are not applicable due to the materials used in fabrication and the local operating environment for the tank. These non-applicable aging mechanisms are listed below with a reason and/or reference for exclusion.

Other age-related degradation mechanisms excluded from this review are listed below:

1. Fatigue: Not a design requirement per References 4.34 and 4.35. Fatigue is not expected due to negligible pressure cycle effect at or near atmospheric conditions and negligible temperature differential at adjacent points. (The same holds true for tanks in ASME Section III, Subsection ND.)

2. Irradiation Assisted Stress Corrosion Cracking: Only affects components in the vicinity of the reactor core-outside of report scope.

3. $475^{\circ} \mathrm{C}$ Embrittlement: Tanks are not made of cast stainless steel; and, operating temperatures are less than $370^{\circ} \mathrm{C}\left[700^{\circ} \mathrm{F}\right]$.

4. $350^{\circ} \mathrm{C}$ Embrittlement: Operating temperatures are less than threshold values $(200$ $370^{\circ} \mathrm{C}\left[390-700^{\circ} \mathrm{F}\right]$.

5. $400-500^{\circ} \mathrm{C}$ Embrittlement: Excluded by Reference 4.16, page 4-81.

6. Temper Embrittlement: Operating temperatures are less than threshold values (350 $\left.-600^{\circ} \mathrm{C}\right)\left[660-1110^{\circ} \mathrm{F}\right]$

7. Strain-Age Embrittlement: Excluded by Reference 4.16, page 4-81 and ANSI B31.1.

8. Graphitization Embrittlement: Excluded by Reference 4.16, page 4-82. 
9. Sigma Phase Embrittlement: Excluded by Reference 4.16, page 4-82.

10. Blue Brittleness: Operating temperatures are less than threshold values (230 $\left.370^{\circ} \mathrm{C}\right)\left[450-700^{\circ} \mathrm{F}\right.$.

11. Neutron Embrittlement: Only affects components inside or adjacent to core-outside of report scope.

12. Wear/Erosion: Tanks do not have moving parts or flows of sufficient velocity to cause these mechanisms.

13. Thermally Induced Stress Relaxation: Excluded by Reference 4.8 .

14. Creep: Operating temperatures needed do not apply to tanks and pools.

\subsection{Tank and Pool Aging Analysis Results}

Detailed aging analyses were completed using tank and pool data collected from the different host sites. These aging analyses were completed using Figures 4-1 and 4-2. The results of the aging analyses are summarized in Tables 4-5, 4-6, and 4-7. A summary of all the aging mechanisms evaluated is shown in Table 4-5. The results of the aging analyses summarized by tank/pool material and fluid type are shown in Table 4-6 and detailed results are evaluated from host utility data in Table 4-7.

Listed below is a summary of the results of the aging analyses presented by tank material and fluid type.

\section{Austenitic Stainless Steel Components}

Containing Air-No significant degradation is expected for stainless steel tank components in air.

Containing Hydrogen Gas-No significant degradation is expected for stainless steel tank components in hydrogen gas.

Containing Clean Water-No significant degradation is expected for stainless steel tank components in water where the quality is monitored and maintained. The potential for MIC exists only where water quality monitoring has been compromised by operations-related crosscontamination or a similar occurrence.

Containing Raw Water-For stainless steel tank components in raw water, stress corrosion cracking, crevice/pitting corrosion, and microbiologically induced corrosion may cause component degradation.

Containing Saturated Steam-No significant degradation is expected for stainless steel tank components in saturated steam where the quality is monitored and maintained. 


\begin{tabular}{|c|c|c|c|}
\hline Section & Potential Aging Mechanism & Significant & $\begin{array}{c}\text { Not } \\
\text { Significant } \\
\end{array}$ \\
\hline \multirow[t]{5}{*}{ 4.2.1 Corrosion } & General Corrosion & $\checkmark$ & \\
\hline & Selective Leaching & $\checkmark$ & \\
\hline & Pitting and Crevice Corrosion & $\checkmark$ & \\
\hline & Galvanic Corrosion & $\checkmark$ & \\
\hline & MIC & $\checkmark$ & \\
\hline \multirow{3}{*}{$\begin{array}{l}\text { 4.2.2 Stress Corrosion Cracking (SCC) } \\
\text { [Section E.2] }\end{array}$} & IGSCC & $\checkmark$ & \\
\hline & IASCC [Section E.2] & & 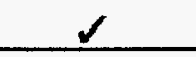 \\
\hline & TGSCC & $\checkmark$ & \\
\hline 4.2.3 Erosion/Corrosion & Erosion/Corrosion & $\checkmark$ & \\
\hline 4.2.4 Two-Phase Erosion & Two-Phase Erosion & $\checkmark$ & \\
\hline 4.2.5 Intergranular Attack & Intergranular Attack & 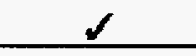 & \\
\hline 4.2.6 Hydrogen Damage & Hydrogen Damage & $\checkmark$ & \\
\hline \multirow[t]{2}{*}{ 4.2.7 Structural Aging (Pools) } & Aggressive Chemicals & $\checkmark$ & \\
\hline & $\begin{array}{l}\text { Corrosion of Embedded } \\
\text { Steel/Rebar }\end{array}$ & $\checkmark$ & \\
\hline E.1 Fatigue [Appendix E] & Fatigue & & $\Omega$ \\
\hline \multirow[t]{8}{*}{ E.3.1 Thermal Embrittlement } & $475^{\circ} \mathrm{C} \mathrm{Embrittlement}$ & & $\checkmark$ \\
\hline & Temper Embrittlement & & $\checkmark$ \\
\hline & $350^{\circ} \mathrm{C}$ Embrittlement & & $\checkmark$ \\
\hline & Blue Brittleness & & $\checkmark$ \\
\hline & Strain-Age Embrittlement & & $\checkmark$ \\
\hline & Graphitization Embrittlement & & $\checkmark$ \\
\hline & Sigma Phase Embrittlement & & $\checkmark$ \\
\hline & $400-500^{\circ} \mathrm{C}$ Embrittlement & & $\checkmark$ \\
\hline E.3.2 Neutron Embrittlement & Neutron Embrittlement & & $\checkmark$ \\
\hline \multirow[t]{3}{*}{ E.4 Wear } & Adhesive Wear & & $\checkmark$ \\
\hline & Abrasive Wear & & $\checkmark$ \\
\hline & Erosion & & $\checkmark$ \\
\hline E.5 Stress Relaxation & Stress Relaxation & & 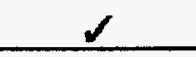 \\
\hline E.6 Creep & Creep & & $\checkmark$ \\
\hline
\end{tabular}


AGING MANAGEMENT GUIDELINE FOR TANKS AND POOLS

\begin{tabular}{|c|c|c|c|c|c|c|c|c|c|c|c|c|c|}
\hline Material & $\begin{array}{l}\text { Fluid } \\
\text { Type }\end{array}$ & $\begin{array}{l}\text { General } \\
\text { Corrosion }\end{array}$ & $\begin{array}{l}\text { Selective } \\
\text { Leaching }\end{array}$ & $\begin{array}{c}\text { Crevice } \\
\text { Pitting } \\
\text { Corrosion } \\
\end{array}$ & $\begin{array}{l}\text { Galvanic } \\
\text { Corrosion }\end{array}$ & MIC & $\begin{array}{l}\text { IG } \\
\text { SCC }\end{array}$ & $\begin{array}{c}\text { TG } \\
\text { SCC }\end{array}$ & $\begin{array}{l}\text { Erosion } \\
\text { Corrosion }\end{array}$ & $\begin{array}{c}\text { Two- } \\
\text { Phase } \\
\text { Erosion } \\
\end{array}$ & IGA & $\begin{array}{c}\text { Hydrogen } \\
\text { Damage } \\
\text { (See Note 2) }\end{array}$ & $\begin{array}{c}\text { Issue } \\
\text { Summary }\end{array}$ \\
\hline \multirow[t]{5}{*}{ Austenitic SS } & Air & No & No & No & No & No & No & No & No & No & No & No & No \\
\hline & Hydrogen & No & No & No & No & No & No & No & No & No & No & No & No \\
\hline & $\begin{array}{l}\text { Clean } \\
\text { Water }\end{array}$ & No & No & No & No & No & No & No & No & No & No & No & No \\
\hline & $\begin{array}{l}\text { Raw } \\
\text { Water } \\
\end{array}$ & No & No & Yes & No & Yes & Yes & Yes & No & No & No & No & Yes \\
\hline & $\begin{array}{l}\text { Saturated } \\
\text { Steam }\end{array}$ & No & No & No & No & No & No & No & No & No & No & No & No \\
\hline \multirow[t]{5}{*}{ Carbon Steel } & Air & Yes & No & No & No & No & No & No & No & No & No & No & Yes \\
\hline & Fuel Oil & Yes & No & Yes & No & Yes & No & No & No & No & No & No & Yes \\
\hline & $\begin{array}{l}\text { Clean } \\
\text { Water }\end{array}$ & Yes & No & Yes & No & No & No & No & No & No & No & No & Yes \\
\hline & \begin{tabular}{|l} 
Raw \\
Water \\
\end{tabular} & Yes & No & Yes & No & Yes & No & No & No & No & No & No & Yes \\
\hline & $\begin{array}{l}\text { Wet } \\
\text { Steam } \\
\end{array}$ & Yes & No & No & No & No & No & No & No & Yes & No & No & Yes \\
\hline $\begin{array}{l}\text { Reinforced } \\
\text { Concrete } \\
\text { (Pools only) }\end{array}$ & $\begin{array}{l}\text { Borated } \\
\text { Water }\end{array}$ & $\begin{array}{c}\text { Yes } \\
\text { See Note } 1\end{array}$ & No & No & No & No & No & No & No & No & No & No & Yes \\
\hline
\end{tabular}


AGING MANAGEMENT GUIDELINE FOR TANKS AND POOLS

Table 4-7. Tank and Pool Aging Analysis Results from Host Utility Data

\begin{tabular}{|c|c|c|c|c|c|c|c|c|c|c|c|c|c|c|c|c|}
\hline $\begin{array}{l}\text { MATERIAL } \\
\text { CLASSIFICATION }\end{array}$ & $\begin{array}{l}\text { FLUID } \\
\text { TYPE }\end{array}$ & DESCRPTION & PART NAME & $\begin{array}{l}\text { SYSTEM } \\
\text { CODE } \\
\text { (1) }\end{array}$ & PLANT & $\begin{array}{l}\text { GENERAL } \\
\text { CORR. }\end{array}$ & $\begin{array}{l}\text { SELECT. } \\
\text { LEACH. }\end{array}$ & $\begin{array}{c}\text { CREVICE/ } \\
\text { PITTING } \\
\text { CORR. }\end{array}$ & $\begin{array}{l}\text { GALVANIC } \\
\text { CORR. }\end{array}$ & MIC & $\begin{array}{l}\text { IG } \\
\text { ScC }\end{array}$ & $\begin{array}{l}\text { TG } \\
\text { scc }\end{array}$ & $\begin{array}{l}\text { EROSION } \\
\text { CORR. }\end{array}$ & $\begin{array}{c}\text { TWO } \\
\text { PHASE } \\
\text { EROSION }\end{array}$ & IGA & $\begin{array}{l}\text { ISSUE } \\
\text { SUMMARY }\end{array}$ \\
\hline $\begin{array}{l}\text { AUSTENTTIC } \\
\text { STAINLESS STEEL }\end{array}$ & AIR & $\begin{array}{l}\text { CHEMICAL FEED SYSTEM } \\
\text { BORON ADDITION TK }\end{array}$ & SHELL & sss & $A$ & No & ко & No & No & No & No & No & No & No & No & No \\
\hline $\begin{array}{l}\text { AUSTENTTC } \\
\text { STAINLESS STEEL }\end{array}$ & AIR & $\begin{array}{l}\text { CHEMICAL FEED SYSTEM } \\
\text { BORON ADDTTION TK }\end{array}$ & TANK COVER & sss & A & No & No & No & No & No & No & No & No & No & No & No \\
\hline $\begin{array}{l}\text { AUSTENTTIC } \\
\text { STAINLESS STEEL }\end{array}$ & AIR & $\begin{array}{l}\text { WASTE GAS COMPRESSOR } \\
\text { KNOCK OUT (KO) DRUM }\end{array}$ & WIRE SCREEN & WD & A & No & No & No & No & No & No & No & No & No & No & No \\
\hline $\begin{array}{l}\text { AUSTENITIC } \\
\text { STAINLESS STEEL }\end{array}$ & HYDROGEN & LOW PRESSURB SURGE TANK & SHELL-TOP & $\mathrm{CH}$ & A & No & No & No & No & No & No & No & No & No & No & No \\
\hline $\begin{array}{l}\text { AUSTENTTIC } \\
\text { STANNLESS STEEL }\end{array}$ & $\begin{array}{l}\text { CLEAN } \\
\text { WATER }\end{array}$ & $\begin{array}{l}800 \text { GAL BORIC ACID } \\
\text { BATCHING TANK }\end{array}$ & NOZZLES & cves & B & No & No & No & No & No & No & No & No & No & No & No \\
\hline $\begin{array}{l}\text { AUSTENTTIC } \\
\text { STAINLESS STEEL }\end{array}$ & $\begin{array}{l}\text { CLEAN } \\
\text { WATER }\end{array}$ & $\begin{array}{l}800 \text { GAL BORTC ACID } \\
\text { BATCHING TANK }\end{array}$ & SHELL \& HEAD & crcs & B & No & No & No & No & No & No & No & No & No & No & No \\
\hline $\begin{array}{l}\text { AUSTENTTC } \\
\text { STAINLESS STEEL }\end{array}$ & $\begin{array}{l}\text { CLEAN } \\
\text { WATER }\end{array}$ & ACCUMULATOR TANKS & CLADDING & sI & D & No & No & No & No & No & No & No & No & No & No & No \\
\hline $\begin{array}{l}\text { AUSTENTTIC } \\
\text { STANLESS STEEL }\end{array}$ & $\begin{array}{l}\text { CLEAN } \\
\text { WATER }\end{array}$ & ACCUMULATOR TANKS & NOZZLES & sI & D & No & No & ко & No & No & No & No & No & No & No & No \\
\hline $\begin{array}{l}\text { AUSTENTTIC } \\
\text { STANLESS STEEL }\end{array}$ & $\begin{array}{l}\text { CLEAN } \\
\text { WATER }\end{array}$ & ACCUMULATOR TANKS & CLADDING & st & B & No & No & No & No & No & No & No & No & No & No & No \\
\hline $\begin{array}{l}\text { AUSTENITIC } \\
\text { STANIESS STEEL }\end{array}$ & $\begin{array}{l}\text { CLEAN } \\
\text { WATER }\end{array}$ & ACCUMULATOR TANKS & NOZZLES & sI & B & No & No & ко & No & No & No & No & No & No & No & No \\
\hline $\begin{array}{l}\text { AUSTENITIC } \\
\text { STANALES ȘEEL }\end{array}$ & $\begin{array}{l}\text { CLEAN } \\
\text { WATER }\end{array}$ & $\begin{array}{l}\text { ACTIVITY DLUTTON \& } \\
\text { DECAY TANK }\end{array}$ & CLAD & WD & A & No & No & No & No & No & No & No & No & No & No & No \\
\hline $\begin{array}{l}\text { AUSTENITC } \\
\text { STAINLESS STEEL }\end{array}$ & $\begin{array}{l}\text { CLEAN } \\
\text { WATER }\end{array}$ & $\begin{array}{l}\text { BORIC ACID MIXING AND } \\
\text { STORAGE TANX }\end{array}$ & $\begin{array}{l}\text { SHELL. } \\
\text { CLADDING }\end{array}$ & cs & A & No & No & No & No & No & No & No & No & No & No & No \\
\hline $\begin{array}{l}\text { AUSTENTTC } \\
\text { STAINLESS STEEL }\end{array}$ & $\begin{array}{l}\text { CLEAN } \\
\text { WATER }\end{array}$ & $\begin{array}{l}\text { BORIC ACID MXING AND } \\
\text { STORAGE TANK }\end{array}$ & $\begin{array}{l}\text { SUPPORT \& } \\
\text { INT PRPNG }\end{array}$ & cs & A & No & No & No & No & so & No & No & No & No & No & No \\
\hline $\begin{array}{l}\text { AUSTENTTC } \\
\text { STARNLESS STEEL }\end{array}$ & $\begin{array}{l}\text { CLEAN } \\
\text { WATER }\end{array}$ & $\begin{array}{l}\text { BORIC ACID MIXING AND } \\
\text { STORAGE TANK }\end{array}$ & HEAD & cs & A & No & No & No & No & No & No & No & No & No & no & No \\
\hline $\begin{array}{l}\text { AUSTENTITC } \\
\text { STAINLESS STERL }\end{array}$ & $\begin{array}{l}\text { CLEAN } \\
\text { WATER }\end{array}$ & BORIC ACID RESERVE TANKS & NOZZLES & cves & в & No & No & No & No & No & No & No & No & No & No & ко \\
\hline $\begin{array}{l}\text { AUSTENTTIC } \\
\text { STAINLESS STEEL }\end{array}$ & $\begin{array}{l}\text { CLEAN } \\
\text { WATER }\end{array}$ & BORIC ACTO RESERVE TANKS & SHELL \& HEAD & cvcs & в & No & No & No & No & No & No & No & No & No & No & No \\
\hline $\begin{array}{l}\text { AUSTENTTC } \\
\text { STAINLESS STEEL }\end{array}$ & $\begin{array}{l}\text { CLEAN } \\
\text { WATER }\end{array}$ & BORC ACID TANKS & NOZZIES & cvcs & B & No & No & No & No & No & No & No & No & No & No & No \\
\hline
\end{tabular}


AGING MANAGEMENT GUIDELINE FOR TANKS AND POOLS

\begin{tabular}{|c|c|c|c|c|c|c|c|c|c|c|c|c|c|c|c|c|}
\hline $\begin{array}{l}\text { MATERIAL } \\
\text { CLASSIFCATION }\end{array}$ & FLUID TYPE & DESCRIPTION & PART NAME & $\begin{array}{l}\text { SYSTEM } \\
\text { CODE } \\
\text { (1) }\end{array}$ & PLANT & $\begin{array}{l}\text { GENERAL } \\
\text { CORR. }\end{array}$ & $\begin{array}{l}\text { SELECT. } \\
\text { LEACH. }\end{array}$ & $\begin{array}{l}\text { CREVICE/ } \\
\text { PITTNG } \\
\text { CORR. }\end{array}$ & $\begin{array}{l}\text { GALVANTC } \\
\text { CORR. }\end{array}$ & MIC & $\begin{array}{l}\text { IG } \\
\text { SCC }\end{array}$ & $\begin{array}{l}\text { TG } \\
\text { scc }\end{array}$ & $\begin{array}{l}\text { EROSION } \\
\text { CORR. }\end{array}$ & $\begin{array}{c}\text { TWO } \\
\text { PHASE } \\
\text { EROSION }\end{array}$ & IGA & $\begin{array}{l}\text { ISSUE } \\
\text { SUMMARY }\end{array}$ \\
\hline $\begin{array}{l}\text { AUSTENTITC } \\
\text { STANRLESS STEEL }\end{array}$ & $\begin{array}{l}\text { CLEAN } \\
\text { WATER }\end{array}$ & BORIC ACID TANKS & SHELL \& HEAD & cves & $B$ & No & No & No & No & No & No & No & No & No & No & No \\
\hline $\begin{array}{l}\text { AUSTENTITC } \\
\text { STAINLESS STEEL }\end{array}$ & $\begin{array}{l}\text { CLEAN } \\
\text { WATER }\end{array}$ & $\begin{array}{l}\text { BORIC ACID MIXING AND } \\
\text { STORAGE TANKS }\end{array}$ & NOZZIES & cres & D & No & No & No & No & No & No & No & No & No & No & No \\
\hline $\begin{array}{l}\text { AUSTENITC } \\
\text { STAINLESS STEEL }\end{array}$ & $\begin{array}{l}\text { CLEAN } \\
\text { WATER }\end{array}$ & $\begin{array}{l}\text { BORIC ACID MIXING AND } \\
\text { STORGAGE TANKS }\end{array}$ & SHELL \& HEAD & cvcs & D & No & No & No & No & No & No & No & No & No & No & No \\
\hline $\begin{array}{l}\text { AUSTENITIC } \\
\text { STAINLESS STEEL }\end{array}$ & $\begin{array}{l}\text { CLEAN } \\
\text { WATER }\end{array}$ & CHEMICAL MIXING TANKS & NOZZIES & cres & B & no & No & No & No & No & No & No & No & No & No & No \\
\hline $\begin{array}{l}\text { AusteNITIC } \\
\text { STAINLESS STEEL }\end{array}$ & $\begin{array}{l}\text { CLEAN } \\
\text { WATER }\end{array}$ & CHEMICAL MIXING TANKS & SHELL \& HEAD & cres & в & no & No & No & No & No & No & No & No & No & No & No \\
\hline $\begin{array}{l}\text { AUSTENITIC } \\
\text { STAINLESS STEEL }\end{array}$ & $\begin{array}{l}\text { CLEAN } \\
\text { WATER }\end{array}$ & GRAVITY DRAIN TANK & HEADS & wD & A & No & No & No & No & No & no & No & No & No & No & No \\
\hline $\begin{array}{l}\text { AUSTENTTIC } \\
\text { STAINLESS STEEL }\end{array}$ & $\begin{array}{l}\text { CLEAN } \\
\text { WATER }\end{array}$ & GRAVITY DRAIN TANK & SHELL & wD & A & No & No & No & No & No & No & No & No & No & No & No \\
\hline $\begin{array}{l}\text { AUSTENTTC } \\
\text { STAINLESS STEEL }\end{array}$ & $\begin{array}{l}\text { CLEAN } \\
\text { WATER }\end{array}$ & LIQUTD HOLDUP TANKS & NOZZIES & crcs & в & No & No & No & No & No & No & No & No & No & No & No \\
\hline $\begin{array}{l}\text { AUSTENITIC } \\
\text { STAIMLESS STEEL }\end{array}$ & $\begin{array}{l}\text { CLEAN } \\
\text { WATER }\end{array}$ & LLQUID HOLDUP TANKS & SHELL \& HEAD & cves & B & No & No & No & No & No & No & No & No & No & No & No \\
\hline $\begin{array}{l}\text { AUSTENITIC } \\
\text { STAINLESS STEEL }\end{array}$ & $\begin{array}{l}\text { CLEAN } \\
\text { WATER }\end{array}$ & $\begin{array}{l}\text { LOW PRESSURE SURGE } \\
\text { TANK }\end{array}$ & INT. PIPE & $\mathrm{CH}$ & A & No & No & No & No & no & No & No & No & No & No & No \\
\hline $\begin{array}{l}\text { AUSTENITTC } \\
\text { STAINLESS STEEL }\end{array}$ & $\begin{array}{l}\text { CLEAN } \\
\text { WATER }\end{array}$ & $\begin{array}{l}\text { LOW PRESSURE SURGE } \\
\text { TANK }\end{array}$ & SHELL \& HEAD & $\mathrm{CH}$ & A & No & No & No & no & No & No & No & No & No & No & No \\
\hline $\begin{array}{l}\text { AUSTENITIC } \\
\text { STAINLESS STEEL }\end{array}$ & $\begin{array}{l}\text { CLEAN } \\
\text { WATER }\end{array}$ & $\begin{array}{l}\text { LOW PRESSURE SURGE } \\
\text { TANK }\end{array}$ & $\begin{array}{l}\text { SPRAY } \\
\text { NOZZLES }\end{array}$ & $\mathrm{CH}$ & A & No & No & No & No & No & No & No & No & No & No & No \\
\hline $\begin{array}{l}\text { AUSTENTTTC } \\
\text { STAINLESS STEEL }\end{array}$ & $\begin{array}{l}\text { CLEAN } \\
\text { WATER }\end{array}$ & $\begin{array}{l}\text { PRIMARY DRAIN } \\
\text { COLLECTING TANK }\end{array}$ & HEAD & WD & A & No & No & No & No & No & No & No & No & No & No & No \\
\hline $\begin{array}{l}\text { AUSTENITIC } \\
\text { STATNLESS STEEL }\end{array}$ & $\begin{array}{l}\text { CLEAN } \\
\text { WATER }\end{array}$ & $\begin{array}{l}\text { PRIMARY DRAIN } \\
\text { COLLECTING TANK }\end{array}$ & SHELL & WD & A & No & No & No & No & No & No & No & No & No & No & No \\
\hline $\begin{array}{l}\text { AUSTENITIC } \\
\text { STAINLESS STEEL. }\end{array}$ & $\begin{array}{l}\text { CLEAN } \\
\text { WATER }\end{array}$ & PRIMARY WATER STRG. TKS & NOZZLES & pws & B & No & No & No & No & No & No & No & No & No & No & No \\
\hline $\begin{array}{l}\text { AUSTENITIC } \\
\text { STAINLESS STEEL }\end{array}$ & $\begin{array}{l}\text { CLEAN } \\
\text { WATER }\end{array}$ & PRIMARY WATER STRG. TKS & SHELL \& HEAD & Pws & в & No & No & No & No & No & No & No & No & No & No & No \\
\hline $\begin{array}{l}\text { AUSTENITTC } \\
\text { STAINLESS STEEL }\end{array}$ & $\begin{array}{l}\text { CLEAN } \\
\text { WATER }\end{array}$ & $\begin{array}{l}\text { PULSATION DAMPENER FOR } \\
\text { CHARGING SYSTEM PUMP }\end{array}$ & SHELL \& PIPE & $\mathrm{CH}$ & A & No & No & No & No & No & No & No & No & No & No & No \\
\hline
\end{tabular}


AGING MANAGEMENT GUIDELINE FOR TANKS AND POOLS

Table 4-7. Tank and Pool Aging Analysis Results from Host Utility Data (continued)

\begin{tabular}{|c|c|c|c|c|c|c|c|c|c|c|c|c|c|c|c|c|}
\hline $\begin{array}{l}\text { MATERIAL } \\
\text { CLASSIFICATION }\end{array}$ & FLUID TYPE & DESCRIPTTON & PART NAME & $\begin{array}{c}\text { SYSTEM } \\
\text { CODE } \\
\text { (l) }\end{array}$ & PLANT & $\begin{array}{l}\text { GENERAL } \\
\text { CORR. }\end{array}$ & $\begin{array}{l}\text { SELECT, } \\
\text { L.EACH. }\end{array}$ & $\begin{array}{l}\text { CREVICE/ } \\
\text { PITTNGG } \\
\text { CORR. }\end{array}$ & $\begin{array}{l}\text { GALVANC } \\
\text { CORR. }\end{array}$ & мIC & $\begin{array}{l}\text { IG } \\
\text { scC }\end{array}$ & $\begin{array}{l}\text { TG } \\
\text { sCC }\end{array}$ & $\begin{array}{l}\text { EROSION } \\
\text { CORR. }\end{array}$ & $\begin{array}{c}\text { TWO } \\
\text { PHASE } \\
\text { EROSION }\end{array}$ & IGA & $\begin{array}{l}\text { ISSUE } \\
\text { SUMMARY }\end{array}$ \\
\hline $\begin{array}{l}\text { AUSTENTTC } \\
\text { STAINLESS STEEL }\end{array}$ & $\begin{array}{l}\text { CLEAN } \\
\text { WATER }\end{array}$ & $\begin{array}{l}\text { REACTOR COOLANT DRAIN } \\
\text { TANKS }\end{array}$ & SHELL \& HEAD & WD & B & No & no & No & No & No & No & No & No & No & No & No \\
\hline $\begin{array}{l}\text { AUSTENTTTC } \\
\text { STANLESS STEEL }\end{array}$ & $\begin{array}{l}\text { CLEAN } \\
\text { WATER }\end{array}$ & $\begin{array}{l}\text { REACTOR COOLANT DRAIN } \\
\text { TANKS }\end{array}$ & SHELL \& HBAD & WD & B & so & No & No & No & No & No & No & No & No & No & No \\
\hline $\begin{array}{l}\text { AUSTENTTIC } \\
\text { STAINLESS STEEL }\end{array}$ & $\begin{array}{l}\text { CLEAAN } \\
\text { WATER }\end{array}$ & REFUEL WTR STRG TKS & NOZZZES & RWST & D & No & No & No & No & No & No & No & No & No & No & No \\
\hline $\begin{array}{l}\text { AUSTENTTC } \\
\text { STANINESS STEEL }\end{array}$ & $\begin{array}{l}\text { CLEAN } \\
\text { WATER }\end{array}$ & REFUEL WTR STRG TKS & SHELL \& HEAD & RWST & D & No & no & No & No & No & No & No & No & No & No & No \\
\hline $\begin{array}{l}\text { AUSTENTTC } \\
\text { STAINLESS STBEL }\end{array}$ & $\begin{array}{l}\text { CLEAN } \\
\text { WATER }\end{array}$ & REFUEL, WTR STRG TKS & NOZZZES & RWST & B & No & No & No & No & No & No & No & No & No & No & No \\
\hline $\begin{array}{l}\text { AUSTENITIC } \\
\text { STAINLESS STEEL }\end{array}$ & $\begin{array}{l}\text { CLEAN } \\
\text { WATER }\end{array}$ & REFUEL WTR STRG TKS & SHELL \& HEAD & RWST & B & No & No & No & No & No & No & No & No & No & No & No \\
\hline $\begin{array}{l}\text { AUSTENITTC } \\
\text { STAINLESS STEEL. }\end{array}$ & $\begin{array}{l}\text { CLEAN } \\
\text { WATER }\end{array}$ & SAFETY INJECTION TANK & SHELL & sI & A & No & No & No & No & No & No & No & No & No & No & No \\
\hline $\begin{array}{l}\text { AUSTENTTC } \\
\text { STAINLESS STEEL }\end{array}$ & $\begin{array}{l}\text { CLEAN } \\
\text { WATER }\end{array}$ & SEAL WATER TANK & SHELL & Dw & A & No & No & No & No & No & No & No & No & so & No & No \\
\hline $\begin{array}{l}\text { AUSTENTTC } \\
\text { STANLESS STEEL }\end{array}$ & $\begin{array}{l}\text { CLEAN } \\
\text { WATER }\end{array}$ & SI ACCUMULATOR TANK & CLADDING & sI & A & No & No & No & No & No & No & No & No & No & No & No \\
\hline $\begin{array}{l}\text { AUSTENTTC } \\
\text { STAINLESS STEEL }\end{array}$ & $\begin{array}{l}\text { CLEAN } \\
\text { WATER }\end{array}$ & SPENT FURL PIT & SHELL & SFP & B & No & No & No & No & No & No & No & No & No & No & No \\
\hline $\begin{array}{l}\text { AUSTENTTTC } \\
\text { STANLESS STEEL }\end{array}$ & $\begin{array}{l}\text { CLEAN } \\
\text { WATER }\end{array}$ & SPENT FUEL POOL & LINER & SFP & D & No & No & No & No & No & No & No & No & No & No & No \\
\hline $\begin{array}{l}\text { AUSTENTTC } \\
\text { STAINLESS STEEL }\end{array}$ & $\begin{array}{l}\text { CLEAN } \\
\text { WATER }\end{array}$ & $\begin{array}{l}\text { SPENT FUEL POOL DRAIN } \\
\text { TANK }\end{array}$ & SHELL & SFP & D & No & No & No & No & No & No & so & No & No & No & No \\
\hline $\begin{array}{l}\text { AUSTENTTC } \\
\text { STAINLESS STEEL }\end{array}$ & $\begin{array}{l}\text { CLEAN } \\
\text { WATER }\end{array}$ & SPENT FUEL, POOL & LINER & SFP & $\mathrm{c}$ & No & No & No & No & No & No & No & No & No & No & No \\
\hline $\begin{array}{l}\text { AUSTENTTIC } \\
\text { STANRESS STEEL }\end{array}$ & $\begin{array}{l}\text { CLEAN } \\
\text { WATER }\end{array}$ & $\begin{array}{l}\text { SPENT FUEL POOL DRAIN } \\
\text { TANK }\end{array}$ & SHELL & SFP & c & No & No & No & No & No & No & No & No & No & No & No \\
\hline $\begin{array}{l}\text { AUSTENITC } \\
\text { STANIESS STEEL. }\end{array}$ & $\begin{array}{l}\text { CLEAN } \\
\text { WATER }\end{array}$ & $\begin{array}{l}\text { SPENT FUEL POOL SKIMMER } \\
\text { SURGE TANK }\end{array}$ & LINER & SPP & c & No & No & No & No & No & No & No & no & No & No & No \\
\hline $\begin{array}{l}\text { AUSTENITIC } \\
\text { STAINLESS STEEL. }\end{array}$ & $\begin{array}{l}\text { CLEAN } \\
\text { WATER }\end{array}$ & $\begin{array}{l}\text { SPENT RESIN STORAGE } \\
\text { TANKS }\end{array}$ & NOZZZES & WD & B & No & no & No & No & No & No & No & No & No & No & No \\
\hline $\begin{array}{l}\text { AUSTENTTIC } \\
\text { STARLESS STEEL }\end{array}$ & $\begin{array}{l}\text { CLEAN } \\
\text { WATER }\end{array}$ & $\begin{array}{l}\text { SPENT RESIN STORAGE } \\
\text { TANKS }\end{array}$ & SHELL \& HEAD & wD & B & No & No & No & No & No & No & No & No & No & No & No \\
\hline
\end{tabular}


AGING MANAGEMENT GUIDELINE FOR TANKS AND POOLS

\section{Table 4-7. Tank and Pool Aging Analysis Results from Host Utility Data (continued)}

\begin{tabular}{|c|c|c|c|c|c|c|c|c|c|c|c|c|c|c|c|c|}
\hline $\begin{array}{c}\text { MATERIAL } \\
\text { CL_ASSIFICATION }\end{array}$ & FLUID TYPE & DESCRIPTION & PART NAME & $\begin{array}{l}\text { SYSTEM } \\
\text { CODE } \\
\text { (1) }\end{array}$ & PLANT & $\begin{array}{l}\text { GENERAL } \\
\text { CORR. }\end{array}$ & $\begin{array}{l}\text { SELECT. } \\
\text { LEACH. }\end{array}$ & $\begin{array}{l}\text { CREVICE/ } \\
\text { PITTING } \\
\text { CORR. }\end{array}$ & $\begin{array}{l}\text { GALVANIC } \\
\text { CORR. }\end{array}$ & Mic & $\begin{array}{l}\text { IG } \\
\text { scc }\end{array}$ & $\begin{array}{l}\text { TG } \\
\text { scc }\end{array}$ & $\begin{array}{l}\text { EROSION } \\
\text { CORR. }\end{array}$ & $\begin{array}{c}\text { TWO } \\
\text { PHASE } \\
\text { EROSION }\end{array}$ & JGA & $\begin{array}{c}\text { ISSUE } \\
\text { SUMMARY }\end{array}$ \\
\hline $\begin{array}{l}\text { AUSTENTTIC } \\
\text { STAINLESS STEEL }\end{array}$ & $\begin{array}{l}\text { CLEAN } \\
\text { WATER }\end{array}$ & $\begin{array}{l}\text { STANDBY LIQUTD STORAGE } \\
\text { TANK }\end{array}$ & NOZZLE & wD & c & No & No & No & No & No & No & No & No & No & No & No \\
\hline $\begin{array}{l}\text { AUSTENTTC } \\
\text { STATNLESS STEEL }\end{array}$ & $\begin{array}{l}\text { CLEAN } \\
\text { WATER }\end{array}$ & $\begin{array}{l}\text { STANDBY LTQUID STORAGE } \\
\text { TANK }\end{array}$ & SHELL & wD & c & No & No & no & No & No & No & No & No & No & No & No \\
\hline $\begin{array}{l}\text { AUSTENTTC } \\
\text { STATMLES STEEL }\end{array}$ & $\begin{array}{l}\text { CLEAN } \\
\text { WATER }\end{array}$ & VOLUME CONTROL TANKS & Nozzzies & cves & B & No & No & No & No & No & No & No & No & No & No & No \\
\hline $\begin{array}{l}\text { AUSTENTTC } \\
\text { STAINLESS STEEL }\end{array}$ & $\begin{array}{l}\text { CLEAN } \\
\text { WATER }\end{array}$ & VOLUME CONTROL TANKS & SHELL \& HEAD & cvcs & B & No & No & No & No & No & No & No & No & No & No & ко \\
\hline $\begin{array}{l}\text { AUSTENTTTC } \\
\text { STAINLESS STEEL }\end{array}$ & $\begin{array}{l}\text { CLEAN } \\
\text { WATER }\end{array}$ & VOLUME CONTROL TANKS & NOZZLES & cres & D & No & No & No & No & No & No & No & No & No & No & No \\
\hline $\begin{array}{l}\text { AUSTENTTC } \\
\text { STAINLESS STEEL }\end{array}$ & $\begin{array}{l}\text { CLEAN } \\
\text { WATER }\end{array}$ & VOLUME CONTROL TANKS & SHELL \& HEAD & cvcs & D & No & No & no & No & No & No & No & No & No & No & No \\
\hline $\begin{array}{l}\text { AUSTENTIIC } \\
\text { STANNLESS STEEL. }\end{array}$ & $\begin{array}{l}\text { CLEAN } \\
\text { WATER }\end{array}$ & WASTE HOLDUP TANK & CLAD & WD & A & no & No & No & No & No & No & No & No & No & No & No \\
\hline $\begin{array}{l}\text { AUSTENITIC } \\
\text { STAINLESS STEEL }\end{array}$ & RAW WATER & CHEMICAL DRAIN TANKS & SHELL \& HEAD & wD & B & No & No & No & No & YES & No & No & No & No & No & YES \\
\hline $\begin{array}{l}\text { AUSTENITIC } \\
\text { STAINLESS STEEL }\end{array}$ & $\begin{array}{l}\text { CLEAN } \\
\text { WATER }\end{array}$ & WASTE HOLDUP TANK & CLAD & wD & A & No & No & No & No & No & No & No & No & No & No & No \\
\hline $\begin{array}{l}\text { AUSTENTTC } \\
\text { STANIESS STEEL }\end{array}$ & RAW WATER & CHEMICAL DRAIN TANKS & SHELL \& HEAD & wD & B & No & No & No & No & YES & No & No & No & No & No & YES \\
\hline $\begin{array}{l}\text { AUSTENTTIC } \\
\text { STAINEESS STEEL }\end{array}$ & RAW WATER & $\begin{array}{l}\text { PULSATION DAMPENER FOR } \\
\text { SAFE SHUTDOWN SYSTEM } \\
\text { PUMP }\end{array}$ & SHELL \& PIPE & sss & A & No & No & YES & No & YES & YES & YES & No & No & No & YES \\
\hline $\begin{array}{l}\text { AUSTENTTIC } \\
\text { STAINLESS STEEL }\end{array}$ & RAW WATER & PZR RELIEF TANKS & NozzLES & PZR & B & No & No & No & No & YES & No & No & No & No & No & YES \\
\hline $\begin{array}{l}\text { AUSTENTTIC } \\
\text { STAINLESS STEEL }\end{array}$ & $\begin{array}{l}\text { SATURATED } \\
\text { STEAM }\end{array}$ & $\begin{array}{l}\text { ACTVITYY DLUUTION \& } \\
\text { DECAY TANK }\end{array}$ & $\begin{array}{l}\text { HEATING } \\
\text { COLLS }\end{array}$ & WD & A & No & No & No & No & No & No & No & No & No & No & No \\
\hline $\begin{array}{l}\text { AUSTENITIC } \\
\text { STAINESSS STEEL }\end{array}$ & $\begin{array}{l}\text { SATURATED } \\
\text { STEAM }\end{array}$ & $\begin{array}{l}\text { BORIC ACID MIXING AND } \\
\text { STORAGE TANE }\end{array}$ & $\begin{array}{l}\text { HEATTNG } \\
\text { COIL-EXT }\end{array}$ & $\mathrm{cs}$ & A & No & No & No & No & No & no & No & No & No & No & No \\
\hline $\begin{array}{l}\text { AUSTENTTIC } \\
\text { STAINEESS STEEL }\end{array}$ & $\begin{array}{l}\text { SATURATED } \\
\text { STEAM }\end{array}$ & $\begin{array}{l}\text { BORTC ACID MIXING AND } \\
\text { STORAGE TANK }\end{array}$ & $\begin{array}{l}\text { HEATING } \\
\text { COIL-INT }\end{array}$ & cs & A & No & No & No & No & No & No & No & No & No & No & No \\
\hline CARBON STEEL & AIR & ACCUMULATOR TANKS & VESSEL WALL & si & B & No & No & No & No & No & No & No & No & No & No & YES \\
\hline
\end{tabular}


AGING MANAGEMENT GUIDELINE FOR TANKS AND POOLS

\begin{tabular}{|c|c|c|c|c|c|c|c|c|c|c|c|c|c|c|c|c|}
\hline $\begin{array}{c}\text { MATERIAL } \\
\text { CLASSIFICATION }\end{array}$ & FLUID TYPE & DESCRIPTTON & PART NAME & $\begin{array}{l}\text { SYSTEM } \\
\text { CODE } \\
\text { (1) }\end{array}$ & PLANT & $\begin{array}{l}\text { GENERAL } \\
\text { CORR. }\end{array}$ & $\begin{array}{l}\text { SELECT. } \\
\text { LEACH. }\end{array}$ & \begin{tabular}{|c|} 
CREVICB/ $/$ PrTTS \\
PORR.
\end{tabular} & $\begin{array}{l}\text { GALVANIC } \\
\text { CORR. }\end{array}$ & MIC & $\underset{\mathrm{scc}}{\mathrm{IG}}$ & $\begin{array}{c}\mathrm{TG} \\
\mathrm{scc}\end{array}$ & $\begin{array}{l}\text { EROSION } \\
\text { CORR. }\end{array}$ & $\begin{array}{c}\text { TWO } \\
\text { PHASE } \\
\text { ERASSON }\end{array}$ & IGA & $\begin{array}{l}\text { ISSUE } \\
\text { SUMMARY }\end{array}$ \\
\hline CARBON STEEL & AIR & $\begin{array}{l}\text { ACTIVITY DILUTION \& } \\
\text { DECAY TANK }\end{array}$ & SHELLAREADS & wD & A & YES & No & No & No & ко & o & No & No & No & No & YES \\
\hline CARBON STEEL & AIR & $\begin{array}{l}\text { BORIC ACID MIXING AND } \\
\text { STORAGE TANK }\end{array}$ & SHELLLBASE & cs & A & o & No & No & No & No & No & № & No & No & мо & No \\
\hline CARBON STEEL & AIR & $\begin{array}{l}\text { DEMIN REG. RECEIVER } \\
\text { TANKS }\end{array}$ & SHELL \& HEAD & WD & B & No & No & No & No & oo & No & No & ко & No & No & No \\
\hline CARBON STEEL & AIR & GAS DECAY DRUM & HEADS & wD & A & YES & No & No & No & No & No & No & No & No & No & YES \\
\hline CARBON STEEL & AIR & GAS DECAY DRUM & HEADS & WD & A & YES & No & No & no & No & No & No & No & No & No & YES \\
\hline CARBON STEEL & AIR & GAS DECAY DRUM & FEADS & WD & A & YES & No & No & No & No & No & No & No & No & No & YES \\
\hline CARBON STEEL & ATR & GAS DECAY DRUM & SHELL & WD & A & YES & No & No & No & No & No & No & No & No & No & YES \\
\hline CARBON STEEL & AIR & GAS DECAY DRUM & SHELL & wD & A & YES & No & No & No & No & No & No & No & No & No & YES \\
\hline CARBON STEEL & AIR & GAS DECAY DRUM & SHELL & WD & A & YES & No & No & No & No & No & No & No & No & No & YES \\
\hline CARBON STEEL & AIR & $\begin{array}{l}\text { PRIMARY BLDG. SUMP } \\
\text { TANK }\end{array}$ & SHELL & WD & A & YES & No & No & No & No & No & No & No & No & No & YES \\
\hline CARBON STEEL & AIR & PZR RELIEF TANKS & MANWAYS & PZR & B & No & No & No & No & No & No & No & No & No & no & No \\
\hline CARBON STEEL & AIR & PZR RELIEF TANKS & SHELL \& FEAD & PZR & B & No & No & No & No & No & No & No & No & No & No & No \\
\hline CARBON STEEL & AIR & SI ACCUMULATOR TANK & SHELL & st & A & No & No & No & No & No & No & No & No & No & No & No \\
\hline CARBON STEEL & AIR & SPENT FUEL POOL & SHELL & SFP & c & No & No & No & No & No & No & No & No & No & No & No \\
\hline CARBON STBEL & AIR & $\begin{array}{l}\text { SPENT FUEL POOL SKIMMER } \\
\text { SURGE TANK }\end{array}$ & SHELL & SPP & c & No & No & No & No & No & No & No & No & No & No & No \\
\hline CARBON STEEL & ARR & STARTING AIR RECEIVERS & SHELL \& HEAD & EDG & B & YES & No & No & No & No & No & No & No & No & No & YES \\
\hline CARBON STEEL & AiR & $\begin{array}{l}\text { VAPOR CONTAINER DRAIN } \\
\text { TANK }\end{array}$ & $\begin{array}{l}\text { SHELL \& } \\
\text { HEAD-UPPER }\end{array}$ & vD & A & YES & No & No & No & No & No & No & No & No & No & YES \\
\hline CARBON STEEL & ATR & $\begin{array}{l}\text { WASTE GAS COMPRESSOR } \\
\text { KNOCK OUT (KO) DRUM }\end{array}$ & SHELL & WD & A & YES & No & No & No & No & No & No & No & No & No & YES \\
\hline
\end{tabular}


AGING MANAGEMENT GUIDELINE FOR TANKS AND POOLS

Table 4-7. Tank and Pool Aging Analysis Results from Host Utility Data (continued)

\begin{tabular}{|c|c|c|c|c|c|c|c|c|c|c|c|c|c|c|c|c|}
\hline $\begin{array}{l}\text { MATERIAL } \\
\text { CLASSIFICATION }\end{array}$ & FLUID TYPE & DESCRIPTION & PART NAME & $\begin{array}{c}\text { SYSTEM } \\
\text { CODE } \\
\text { (1) }\end{array}$ & PLANT & $\begin{array}{l}\text { GENERAL } \\
\text { CORR. }\end{array}$ & $\begin{array}{l}\text { SELECT. } \\
\text { LEACH. }\end{array}$ & $\begin{array}{c}\text { CREVICE/ } \\
\text { PITTING } \\
\text { CORR. }\end{array}$ & $\begin{array}{l}\text { GALVANIC } \\
\text { CORR. }\end{array}$ & MIC & $\begin{array}{l}\text { IG } \\
\text { ScC }\end{array}$ & $\begin{array}{l}\text { TG } \\
\text { scc }\end{array}$ & $\begin{array}{l}\text { EROSION } \\
\text { CORR. }\end{array}$ & $\begin{array}{c}\text { TWO } \\
\text { PHASE } \\
\text { EROSION }\end{array}$ & IGA & $\begin{array}{l}\text { ISSUE } \\
\text { SUMMARY }\end{array}$ \\
\hline CARBON STEEL & AIR & WASTE GAS SURGE DRUM & HEADS & WD & A & YES & No & No & No & No & No & No & No & No & No & YES \\
\hline CARBON STEEL & AIR & WASTE GAS SURGE DRUM & SHELL & WD & A & YES & No & No & No & No & No & No & No & no & No & YES \\
\hline CARBON STEEL, & AR & WASTE HOLDUP TANK & SHELL/HEADS & WD & A & YES & No & No & No & No & No & No & No & No & No & YES \\
\hline CARBON STEEL & FUEL on & DIESEL DAY TANKS & BODY & Fo & A & YES & No & No & No & YES & No & No & No & No & No & YES \\
\hline CARBON STEEL & FUEL ORL & $\begin{array}{l}\text { DIESEL ENG. GEN. F/O STRG } \\
\text { TANKS }\end{array}$ & NOZZLES & EDG & B & YES & No & YES & No & YES & No & No & No & No & No & YES \\
\hline CARBON STEEL & FUEL OIT & $\begin{array}{l}\text { DIESEL ENG. GEN. F/O STRG } \\
\text { TANKS }\end{array}$ & SHELL \& HEAD & EDG & B & YES & No & YES & No & YES & No & No & No & No & No & YES \\
\hline CARBON STEEL & FUEL OR. & $\begin{array}{l}\text { DIESEL ENG. GEN. FUEL OIL. } \\
\text { DAY TKS }\end{array}$ & SHELL \& HEAD & EDG & B & YES & No & No & No & YES & No & No & No & No & No & YES \\
\hline CARBON STEEL. & FUEL Oll & $\begin{array}{l}\text { DIESEL FUEL OIL DAY } \\
\text { TANK }\end{array}$ & NOZZLE & DFO & c & YES & No & NO & No & YES & No & No & No & No & No & YES \\
\hline CARBON STEEL & FUEL OIL & $\begin{array}{l}\text { DIESEL FUEL OIL DAY } \\
\text { TANK }\end{array}$ & SHELL & DFO & $\mathrm{c}$ & YES & No & No & No & YES & No & no & No & No & no & YES \\
\hline CARBON STEEL & FUBL OIL & $\begin{array}{l}\text { DIESEL FUEL OIL DAY } \\
\text { TANK }\end{array}$ & NOZZLEE & DFo & D & YES & No & No & No & YES & no & No & No & No & No & YES \\
\hline CARBON STEEL & FUEL OIL & $\begin{array}{l}\text { DIESEL FUEL OIL DAY } \\
\text { TANK }\end{array}$ & SHELL & DFO & D & YES & No & No & No & YES & No & No & No & No & No & YES \\
\hline CARBON STEEL & FUEL OIL & $\begin{array}{l}\text { FIRE PUMP DIESEL FUEL } \\
\text { OIL TANK }\end{array}$ & BODY & FS & A & YES & No & No & No & YES & No & No & No & No & No & YES \\
\hline CARBON STEEL & FUEL OR & FUEL OIL OVERFLOW TANK & BODY & Fo & A & YES & No & No & no & YES & No & no & No & No & no & YES \\
\hline CARBON STEEL & FUEL OLL & FUEL OIL DRIP TANK & BODY & Fo & D & YES & No & No & No & YES & No & No & No & No & No & YES \\
\hline CARBON STEEL & FUEL OLL & FUEL OIL STORAGE TANK & BODY & Fo & A & YES & No & No & No & YES & No & no & No & No & No & YES \\
\hline CARBON STEEL & FUEL OIt & $\begin{array}{l}\text { SSS DIESEL FUEL OIL DAY } \\
\text { TANK }\end{array}$ & SHELL & sss & A & YES & No & No & No & YES & No & No & No & No & No & YES \\
\hline CARBON STEEL & $\begin{array}{l}\text { CLEAN } \\
\text { WATER }\end{array}$ & ASH DEWATERING SUMP & SHELL & WD & A & YES & No & No & no & No & No & No & No & No & No & YES \\
\hline
\end{tabular}


AGING MANAGEMENT GUIDELINE FOR TANKS AND POOLS

\begin{tabular}{|c|c|c|c|c|c|c|c|c|c|c|c|c|c|c|c|c|}
\hline $\begin{array}{l}\text { MATERIAL } \\
\text { CLASSIFCATION }\end{array}$ & FLUID TYPE & DESCRIPTION & PART NAME & $\begin{array}{l}\text { SYSTEM } \\
\text { CODE } \\
\text { (1) }\end{array}$ & PLANT & $\begin{array}{c}\text { GENERAL } \\
\text { CORR. }\end{array}$ & $\begin{array}{l}\text { SELECT. } \\
\text { LEACH. }\end{array}$ & $\begin{array}{c}\text { CREVICE/ } \\
\text { PITTING } \\
\text { CORR. }\end{array}$ & $\begin{array}{l}\text { GALVANIC } \\
\text { CORR. }\end{array}$ & MIC & $\begin{array}{l}\text { IG } \\
\text { scC }\end{array}$ & $\begin{array}{l}\text { TG } \\
\text { ScC }\end{array}$ & $\begin{array}{l}\text { EROSION } \\
\text { CORR. }\end{array}$ & $\begin{array}{c}\text { TWO } \\
\text { PHASE } \\
\text { EROSION }\end{array}$ & IGA & $\begin{array}{l}\text { ISSUE } \\
\text { SUMMARY }\end{array}$ \\
\hline CARBON STEEL & $\begin{array}{l}\text { CLEAN } \\
\text { WATER }\end{array}$ & CCW SURGE TANKS & NOZZLES & $\mathrm{cc}$ & B & YES & No & No & No & No & No & No & No & No & No & YES \\
\hline CARBON STEEL & $\begin{array}{l}\text { CLEAN } \\
\text { WATER }\end{array}$ & CCW SURGE TANKS & SHELL \& HEAD & $\mathrm{cc}$ & $B$ & YES & No & No & No & No & No & No & No & No & No & YES \\
\hline CARBON STEEL & $\begin{array}{l}\text { CLEAN } \\
\text { WATER }\end{array}$ & $\begin{array}{l}\text { COMP COOLING WTR CHEM } \\
\text { ADD TANKS }\end{array}$ & NOZZLLES & $\mathrm{cc}$ & B & YES & No & No & No & No & No & No & No & No & No & YES \\
\hline CARBON STEEL & $\begin{array}{l}\text { CLEAN } \\
\text { WATER }\end{array}$ & $\begin{array}{l}\text { COMP COOLING WTR CHEM } \\
\text { ADD TANKS }\end{array}$ & SHELL \& HEAD & $\mathrm{cc}$ & B & YES & No & No & No & No & No & No & No & No & No & YES \\
\hline CARBON STEEL & $\begin{array}{l}\text { CLEAN } \\
\text { WATER }\end{array}$ & $\begin{array}{l}\text { COMPONENT COOLING } \\
\text { WATER SURGE TANK }\end{array}$ & HEAD & $\mathrm{cc}$ & D & YES & No & No & No & No & No & No & No & No & No & YES \\
\hline CARBON STEEL & $\begin{array}{l}\text { CLEAN } \\
\text { WATER }\end{array}$ & $\begin{array}{l}\text { COMPONENT COOLING } \\
\text { WATER SURGE TANK }\end{array}$ & SHELL & $\mathrm{CC}$ & $\mathfrak{D}$ & YES & No & No & No & No & No & No & No & No & No & YES \\
\hline CARBON STEEL & $\begin{array}{l}\text { CLEAN } \\
\text { WATER }\end{array}$ & $\begin{array}{l}\text { COMPONENT COOLING } \\
\text { WATER SURGE TANK }\end{array}$ & HEAD & $\mathrm{cc}$ & A & YES & No & No & No & No & No & No & No & No & No & YES \\
\hline CARBON STEEL & $\begin{array}{l}\text { CLEAN } \\
\text { WATER }\end{array}$ & $\begin{array}{l}\text { COMPONENT COOLING } \\
\text { WATER SURGE TANK }\end{array}$ & SHELL & $\mathrm{cc}$ & $A$ & YES & No & No & No & No & No & No & No & No & No & YES \\
\hline CARBON STEEL & $\begin{array}{l}\text { CLEAN } \\
\text { WATER }\end{array}$ & $\begin{array}{l}\text { CONDENSATE STORAGE } \\
\text { TANK (CLEAN) }\end{array}$ & NOZZLE & COND & c & YES & No & No & No & No & No & NO & No & No & No & YES \\
\hline CARBON STEEL & $\begin{array}{l}\text { CLAAAN } \\
\text { WATER }\end{array}$ & $\begin{array}{l}\text { CONDENSATE STORAGE } \\
\text { TANK (CLEAN) }\end{array}$ & SHELL & COND & c & YES & No & YES & No & No & No & No & No & No & No & YES \\
\hline CARBON STEEL & $\begin{array}{l}\text { CLEAN } \\
\text { WATER }\end{array}$ & $\begin{array}{l}\text { CONDENSATE STORAGE } \\
\text { TANK (CONTAMINATED) }\end{array}$ & NOZZLE & COND & c & YES & No & No & No & No & No & No & No & No & No & YES \\
\hline CARBON STEEL & $\begin{array}{l}\text { CLEAN } \\
\text { WATER }\end{array}$ & $\begin{array}{l}\text { CONDENSATE STORAGE } \\
\text { TANK (CONTAMNANATED) }\end{array}$ & SHELL & COND & c & YES & No & YES & No & No & No & No & No & No & No & YES \\
\hline CARBON STEEL & $\begin{array}{l}\text { CLEAN } \\
\text { WATER }\end{array}$ & $\begin{array}{l}\text { CONDENSATE STORAGE } \\
\text { TANKS }\end{array}$ & NOZZLES & COND & B & YES & No & YES & No & No & No & No & No & No & No & YES \\
\hline CARBON STEEL & $\begin{array}{l}\text { CLEAN } \\
\text { WATER }\end{array}$ & $\begin{array}{l}\text { CONDENSATE STORAGE } \\
\text { TANKS }\end{array}$ & SHELL \& HEAD & COND & D & YES & No & YES & No & No & No & No & No & No & No & YES \\
\hline CARBON STEEL & $\begin{array}{l}\text { CLEAN } \\
\text { WATER }\end{array}$ & $\begin{array}{l}\text { CONDENSATE STORAGE } \\
\text { TANKS }\end{array}$ & NOZZLES & COND & D & YES & No & YES & No & No & No & No & No & No & No & YES \\
\hline CARBON STEEL. & $\begin{array}{l}\text { CLEAN } \\
\text { WATER }\end{array}$ & $\begin{array}{l}\text { CONDENSATE STORAGE } \\
\text { TANKS }\end{array}$ & SHELL \& HEAD & COND & B & YES & No & YES & No & No & No & No & no & No & No & YES \\
\hline CARBON STEEL & $\begin{array}{l}\text { CLEAN } \\
\text { WATER }\end{array}$ & MONITORED WASTE TANK & HEADS & WD & A & YES & No & No & No & No & No & No & No & No & No & YES \\
\hline
\end{tabular}


AGING MANAGEMENT GUIDELINE FOR TANKS AND POOLS

\begin{tabular}{|c|c|c|c|c|c|c|c|c|c|c|c|c|c|c|c|c|}
\hline \multicolumn{17}{|c|}{ Table 4-7. Tank and Pool Aging Analysis Results from Host Utility Data (continued) } \\
\hline $\begin{array}{l}\text { MATERIAL } \\
\text { CLASSIFCATION }\end{array}$ & FLUID TYPE & DESCRIPTION & PART NAME & $\begin{array}{c}\text { SYSTEM } \\
\text { CODE } \\
\text { (1) }\end{array}$ & PLANT & $\begin{array}{c}\text { GENERAL } \\
\text { CORR. }\end{array}$ & $\begin{array}{l}\text { SELECT. } \\
\text { LEACH. }\end{array}$ & $\begin{array}{l}\text { CREVICE/ } \\
\text { PITTING } \\
\text { CORR. }\end{array}$ & $\begin{array}{c}\text { GALVANIC } \\
\text { CORR. }\end{array}$ & MIC & $\begin{array}{l}\text { IG } \\
\text { SCC }\end{array}$ & TG & $\begin{array}{l}\text { EROSION } \\
\text { CORR. }\end{array}$ & $\begin{array}{c}\text { TWO } \\
\text { PHASE } \\
\text { EROSION }\end{array}$ & IGA & $\begin{array}{l}\text { ISSUE } \\
\text { SUMMARY }\end{array}$ \\
\hline CARBON STEEL & $\begin{array}{l}\text { CLEAN } \\
\text { WATER }\end{array}$ & MONTTORED WASTE TANK & HEADS & WD & A & YES & No & No & No & No & No & No & No & No & No & YES \\
\hline CARBON STEEL & $\begin{array}{l}\text { CLEAN } \\
\text { WATER }\end{array}$ & MONITORED WASTE TANK & SHELL & wD & A & YES & No & No & No & No & No & no & No & No & No & YES \\
\hline CARBON STEEL & $\begin{array}{l}\text { CLEAN } \\
\text { WATER }\end{array}$ & MONITORED WASTE TANK & SHELL & WD & $A$ & YES & No & No & no & No & No & No & No & No & No & YES \\
\hline CARBON STEEL & $\begin{array}{l}\text { CLEAN } \\
\text { WATER }\end{array}$ & $\begin{array}{l}\text { NEUTRON SHIELD SURGE } \\
\text { TANK }\end{array}$ & HEAD & $\mathrm{cc}$ & A & YES & No & No & no & no & No & No & No & No & No & YES \\
\hline CARBON STEEL & $\begin{array}{l}\text { CLEAN } \\
\text { WATER }\end{array}$ & $\begin{array}{l}\text { NEUTRON SHIELD SURGE } \\
\text { TANK }\end{array}$ & SHELL & $\mathrm{cc}$ & A & YES & No & No & No & no & No & No & No & No & No & YES \\
\hline CARBON STEEL & $\begin{array}{l}\text { CLEAN } \\
\text { WATER }\end{array}$ & NEUTRON SHELLD TANK & DOWNCOMER & $\mathrm{cc}$ & A & YES & No & No & No & no & No & No & No & No & No & YES \\
\hline CARBON STEEL & $\begin{array}{l}\text { CLEAN } \\
\text { WATER }\end{array}$ & NEUTRON SHIELD TANK & SHELL & $\mathrm{cc}$ & A & YES & No & No & No & no & No & No & No & No & No & YES \\
\hline CARBON STEEL & $\begin{array}{l}\text { CLEAN } \\
\text { WATER }\end{array}$ & PRIMARY WATER TANK & $\begin{array}{l}\text { HEATING } \\
\text { CoIIS }\end{array}$ & Dw & в & YES & No & No & No & No & No & No & No & No & No & YES \\
\hline CARBON STEEL & $\begin{array}{l}\text { CLEAN } \\
\text { WATER }\end{array}$ & PRIMARY WATER TANK & $\begin{array}{l}\text { HEATING } \\
\text { COILS }\end{array}$ & DW & $D$ & YES & No & No & No & No & No & No & No & No & No & YES \\
\hline CARBON STEEL & $\begin{array}{l}\text { CLEAN } \\
\text { WATER }\end{array}$ & RBCCW SURGE TANK & NOZZLE & $\mathrm{ccw}$ & c & YES & No & No & No & No & No & No & nо & No & No & YES \\
\hline CARBON STEEL & $\begin{array}{l}\text { CLEAN } \\
\text { WATER }\end{array}$ & RBCCW SURGE TANK & SHELL & $\mathrm{ccw}$ & c & YES & No & No & No & No & No & no & No & No & No & YES \\
\hline CARBON STEEL & $\begin{array}{l}\text { CLEAN } \\
\text { WATER }\end{array}$ & $\begin{array}{l}\text { VAPOR CONTAINER DRAIN } \\
\text { TANK }\end{array}$ & $\begin{array}{l}\text { SHELL \& } \\
\text { HEAD-LOWER }\end{array}$ & vo & A & YES & o & No & No & No & No & No & กั & No & No & YES \\
\hline CARBON STEEL & RAW WATER & $\begin{array}{l}\text { AUX. BLR. BLOWDOWN } \\
\text { TANK }\end{array}$ & SHELL & sw & A & YES & No & YES & No & No & No & No & No & No & No & YES \\
\hline CARBON STEEL & RAW WATER & $\begin{array}{l}\text { EQUSPMENT DRAIN REC. } \\
\text { TANKS }\end{array}$ & SHELL \& HEAD & WD & B & YES & No & YES & No & YES & No & No & No & No & No & YES \\
\hline CARBON STEEL & RAW WATER & $\begin{array}{l}\text { FIRE WATER \& TRANSFER } \\
\text { TANK }\end{array}$ & NOZZLES & FS & B & YES & No & YES & No & YES & No & No & No & No & No & YES \\
\hline CARBON STEEL & RAW WATER & $\begin{array}{l}\text { FIRE WATER \& TRANSFER } \\
\text { TANK }\end{array}$ & SHELL \& HEAD & FS & B & YES & no & YES & No & YES & No & No & No & No & No & YES \\
\hline CARBON STEEL & RAW WATER & $\begin{array}{l}\text { FiRE WATER STORAGE } \\
\text { TANK }\end{array}$ & NOZzLE & FS & c & YES & No & YES & No & YES & No & No & No & No & No & YES \\
\hline
\end{tabular}


AGING MANAGEMENT GUIDELINE FOR TANKS AND POOLS

\begin{tabular}{|c|c|c|c|c|c|c|c|c|c|c|c|c|c|c|c|c|}
\hline $\begin{array}{c}\text { MATERIAL } \\
\text { CLASSIEICATION }\end{array}$ & FEUD TYPE & DESCRPTTION & PART NAME & $\begin{array}{l}\text { SYSTEM } \\
\text { CODE } \\
\text { (1) }\end{array}$ & PLANT & $\begin{array}{l}\text { GENERAL } \\
\text { CORR. }\end{array}$ & $\begin{array}{l}\text { SELECT. } \\
\text { LEACH. }\end{array}$ & $\begin{array}{l}\text { CREVICE/ } / \\
\text { PITTING } \\
\text { CORR. }\end{array}$ & $\begin{array}{l}\text { GALVANIC } \\
\text { CORR. }\end{array}$ & MIC & $\underset{\mathrm{IcC}}{\mathrm{IG}}$ & $\begin{array}{l}\mathrm{TG} \\
\text { scc }\end{array}$ & $\begin{array}{l}\text { EROSION } \\
\text { CoRR. }\end{array}$ & $\begin{array}{c}\text { TWO } \\
\text { PHASE } \\
\text { EROSLON }\end{array}$ & IGA & $\begin{array}{c}\text { ISSUE } \\
\text { SUMMART }\end{array}$ \\
\hline CARBON STEELL & RAW WATER & $\begin{array}{l}\text { FRE WATER STORAGE } \\
\text { TANK }\end{array}$ & SHELL & Fs & c & YES & No & YES & ко & YES & No & No & No & № & no & YES \\
\hline CARBON STEELL & RAW WATER & $\begin{array}{l}\text { FRE WATER STORAGE } \\
\text { TANK }\end{array}$ & SHELL & $\mathrm{Fs}$ & $\mathrm{D}$ & YES & No & YES & No & YES & No & No & No & No & no & YES \\
\hline CARBON STEEL & RAW WATER & $\begin{array}{l}\text { FRE WATER STORAGE } \\
\text { TANK }\end{array}$ & SHELL & is & A & YES & No & YES & No & YES & No & No & No & No & No & YES \\
\hline CARBON STEBL & RAW WATER & FRE WATER TANK & NOZZLES & Fs & B & YES & No & YES & No & YES & No & No & No & No & No & YES \\
\hline CARBON STEEL & RAW WATER & FRE WATER TANK & SHELL \& HEAD & Fs & B & YES & No & YES & No & YES & No & No & No & No & No & YES \\
\hline CARBON STEEL & RAW WATER & FLOOR DRAIN REC. TANKS & SHELL \& HEAD & wD & B & YES & No & YES & No & YES & No & No & No & No & No & YES \\
\hline CARBON STEEL & RAW WATER & HPCS FLOOR/PIT TANK & SHELL & несS & c & YES & No & YES & YES & YES & No & No & No & No & no & YES \\
\hline CARBON STEEL & RAW WATER & $\begin{array}{l}\text { MISC. EQUTPMENT DRAIN } \\
\text { TANKS }\end{array}$ & SHELL \& HEAD & wD & B & YES & No & YES & No & YES & ко & no & no & No & no & YES \\
\hline CARBON STEEL & RAW WATER & $\begin{array}{l}\text { MISC. EQUTPMENT DRAIN } \\
\text { TANKS }\end{array}$ & SHELL \& HEAD & WD & D & YES & No & YES & No & YES & No & No & No & No & No & YES \\
\hline CARBON STEBL & RAW WATER & $\begin{array}{l}\text { PRESSURE MAINTENANCE } \\
\text { TANK }\end{array}$ & SHELL & Fs & A & YES & No & YES & No & YES & No & so & No & No & No & YES \\
\hline CARBON STEEL & RAW WATER & WASTE HOLDUP TANK & $\begin{array}{l}\text { HEATING } \\
\text { COILS }\end{array}$ & wD & A & YES & No & YES & No & YES & No & so & No & No & No & YES \\
\hline CARBON STEEL & WEr STEAM & BOILER BLOWDOWN TANK & SHELL_CPPPER & vD & A & YES & No & No & No & No & No & No & о & YES & No & YES \\
\hline NON METALULC & AIR & $\begin{array}{l}\text { SSS DIESEL FUEL OIL } \\
\text { STORAGE TANK }\end{array}$ & FLL LINES & sss & A & No & No & No & No & мо & ко & no & No & No & so & ко \\
\hline NON METALLIC & FUEL OLL & FUEL OLL STORAGE TANK & NozzZE & DFO & c & No & No & мо & No & so & ко & No & ко & No & No & No \\
\hline NON METALLIC & FUEL OIL & FUEL OIL STORAGE TANK & SHELL & DFO & c & No & No & No & No & No & No & No & No & No & No & No \\
\hline NON METALLIC & FUEL OIL & $\begin{array}{l}\text { SSS DESERE FUEL OIL } \\
\text { STORAGE TANK }\end{array}$ & DROP TUBES & sss & A & No & No & No & No & No & no & No & No & No & No & No \\
\hline NON METALLLC & FUEL OIL & $\begin{array}{l}\text { SSS DEESEL FURLL OIL } \\
\text { STORAGE TANK }\end{array}$ & FOOT VALVE & sss & A & No & No & No & No & No & no & No & No & No & No & No \\
\hline NON METALLIC & FUEL OIL & $\begin{array}{l}\text { SSS DESEEL FUEL OIL } \\
\text { STORAGE TANK }\end{array}$ & SHELL & sss & A & ко & кo & No & No & No & мо & No & so & o & No & мo \\
\hline
\end{tabular}


AGING MANAGEMENT GUIDELINE FOR TANKS AND POOLS

Table 4-7. Tank and Pool Aging Analysis Results (continued)

\begin{tabular}{|c|c|c|c|c|c|c|c|c|c|c|c|c|c|c|c|c|}
\hline $\begin{array}{c}\text { MATERJAL } \\
\text { CLASSIFICATION }\end{array}$ & $\begin{array}{l}\text { FLUUD } \\
\text { TYPE }\end{array}$ & DESCRUPTION & PART NAME & $\begin{array}{l}\text { SYSTEM } \\
\text { CODE } \\
\text { (I) }\end{array}$ & PLANT & $\begin{array}{l}\text { GENERAL } \\
\text { CORR. }\end{array}$ & $\begin{array}{l}\text { EROSION } \\
\text { CORR. }\end{array}$ & $\begin{array}{l}\text { TWO } \\
\text { PHASE } \\
\text { EROSION }\end{array}$ & $\underset{\text { SCC }}{\text { TG }}$ & $\begin{array}{l}\text { IG } \\
\text { ScC }\end{array}$ & IGA & $\begin{array}{l}\text { CREvICE/ } \\
\text { PITTING } \\
\text { CORR. }\end{array}$ & MIC & $\begin{array}{l}\text { GALVANIC } \\
\text { CORR. }\end{array}$ & $\begin{array}{l}\text { SELECT. } \\
\text { LEACH. }\end{array}$ & $\begin{array}{l}\text { ISSUE } \\
\text { SUMMARY }\end{array}$ \\
\hline NON METALUIC & $\begin{array}{l}\text { CLEAN } \\
\text { WATER }\end{array}$ & ASH DEWATERING SUMP & CLAD & wD & A & No & NO & No & No & No & No & No & No & No & No & No \\
\hline NON METALLIC & $\begin{array}{l}\text { CLEAN } \\
\text { WATER }\end{array}$ & PRIMARY BLDG. SUMP TANK & CLAD & wo & A & no & No & No & No & No & No & No & No & No & no & No \\
\hline NON METALUIC & $\begin{array}{l}\text { CLEAN } \\
\text { WATER }\end{array}$ & $\begin{array}{l}\text { PULSATION DAMPENER FOR } \\
\text { CHARGING SYSTEM PUMP }\end{array}$ & BLADDER & $\mathrm{CH}$ & A & No & No & No & No & No & No & No & No & No & No & No \\
\hline NON METALLUC & $\begin{array}{l}\text { RAW } \\
\text { WATER }\end{array}$ & RESTN STORAGE TANK & SHELL & $\mathrm{SF}$ & $\mathrm{D}$ & No & No & No & No & No & No & no & No & No & no & No \\
\hline NON METALUIC & $\begin{array}{l}\text { RAW } \\
\text { WATER }\end{array}$ & $\begin{array}{l}\text { PULSATION DAMPENER FOR } \\
\text { SAFE SHUTDOWN SYSTEM } \\
\text { PUMP }\end{array}$ & DIAPHRAGM & sss & A & No & No & No & No & No & No & No & No & No & No & No \\
\hline
\end{tabular}


AGING MANAGEMENT GUIDELINE FOR TANKS AND POOLS

\begin{tabular}{||l|l|l||}
\hline Table 4-7. Tank and Pool Aging Analysis Results (concluded) \\
\hline SYSTEM CODE & SYSTEM NAME & APPLIES TO PLANT(S) \\
\hline CC & COMPONENT COOLING WATER SYSTEM & A, B, D \\
\hline CCW & COMPONENT COOLING WATER SYSTEM & C \\
\hline CH & CHEMICAL VOLUME CONTROL SYSTEM & A \\
\hline COND & CONDENSATE SYSTEM & B, C, D \\
\hline CS & CHEMICAL SHUTDOWN SYSTEM & A \\
\hline CVCS & CHEMICAL VOLUME CONTROL SYSTEM & B, D \\
\hline DFO & DIESEL FUEL OIL SYSTEM & C, D \\
\hline DW & DEMINERALIZED WATER SYSTEM & A, B, D \\
\hline EDG & EMERGENCY DIESEL GENERATOR SYSTEM & B \\
\hline FO & FUEL OIL SYSTEM & A, D \\
\hline FS & FIRE SUPPRESSION SYSTEM & A, B, C, D \\
\hline HPCS & HIGH PRESSURE CORE SPRAY & C \\
\hline PWS & PRIMARY WATER SYSTEM & B \\
\hline PZR & PRESSURIZER SYSTEM & B \\
\hline RWST & REFUELING WATER STORAGE TANK SYSTEM & B, D \\
\hline SF & SPENT FUEL SYSTEM & D \\
\hline SFP & SPENT FUEL POOL COOLING SYSTEM & B, C, D \\
\hline SI & SAFETY INJECTION SYSTEM & A, B, D \\
\hline SSS & SAFE SHUTDOWN SYSTEM & A \\
\hline SW & SERVICE WATER SYSTEM & A \\
\hline VD & VENT AND DRAIN SYSTEM & A \\
\hline WD & WASTE DISPOSAL SYSTEM & A, B, C, D \\
\hline
\end{tabular}




\section{Carbon Steel Tank Components}

Containing Air-For carbon steel tank components in air, general corrosion may cause component degradation.

Containing Fuel Oil-For carbon steel tank components in fuel oil, general corrosion, microbiologically induced corrosion, and hydrogen damage/embrittlement may cause component degradation. If the tank is buried, crevice/pitting corrosion is likely.

Containing Clean Water-For carbon steel tank components in clean water, general corrosion may cause component degradation. If the tank is located outside, crevice/pitting corrosion and MIC are likely on the outside surface. If the tank is buried, crevice pitting corrosion and MIC are likely on the outside surfaces. MIC can occur on interior surfaces when water quality monitoring and maintenance have been compromised.

Containing Raw Water-For carbon steel tank components in raw water, general corrosion, crevice/pitting corrosion, and microbiologically induced corrosion may cause component degradation.

Containing Saturated Steam-For carbon steel tank components in saturated steam, general corrosion and two-phase erosion may cause component degradation.

\section{Non-Metallic Tank Components} in air.

Containing Air-No significant degradation is expected for non-metallic tank components

Containing Fuel Oil-No significant degradation is expected for non-metallic tank components in fuel oil.

Containing Clean Water-No significant degradation is expected for non-metallic tank components in clean water.

Containing Raw Water-No significant degradation is expected for non-metallic tank components in raw water.

\section{Reinforced Concrete Pool Components in Borated Water}

Exposure to borated water may cause spalling, cracking, and/or erosion to the concrete surface. This degradation could cause corrosion of the embedded steel/rebar if exposure to borated water persists. This exposure to borated water can only occur, however, if a leak develops in the pool liner plate.

\subsection{References}

4.1 EPRI Research Project RP-2812-2, "Sourcebook for Microbiologically Influenced Corrosion in Nuclear Power Plants," Structural Integrity Associates, Inc., 1988. 
4.2 Metals Handbook Ninth Edition, Volume 11, "Failure Analysis and Prevention," American Society for Metals, Copyright 1986, pp. 130-133, 150-154, 203-208.

4.3 EPRI Report TR-103839, "Boiling Water Reactor Vessel Internals License Renewal Industry Report," Revision 1, July 1994.

4.4 EPRI Report TR-103836, "Boiling Water Reactor Vessel License Renewal Industry Report," Revision 1, July 1994.

4.5 EPRI Report TR-103844, "PWR Reactor Coolant System License Renewal Industry Report," Revision 1, July 1994.

4.6 Metals Handbook Ninth Edition, Volume 13, "Corrosion," American Society for Metals, Copyright 1987, pp. 935-936.

4.7 EPRI Report NP-3673-LD, "Long-Term Integrity of Nuclear Power Plant Components," October 1984, pp. 1-1, 2-44 through 2-50.

4.8 "Component Life Estimation: LWR Structura1 Materials Degradation Mechanisms," M. E. Lapides, EPRI Report NP-5461, September 1987.

4.9 EPRI Report TR-103842, "Class I Structures License Renewal Industry Report," December 1991.

4.10 Engineering Materials And Their Applications, Richard A. Flinn and Paul K. Trojan, Houghton Mifflin Company, 1975.

4.11 "Corrosion-Related Failures in Feedwater Heaters," B. C. Syrett, EPRI Report CS-3184, July 1983.

4.12 "Environmental Effects on Components: Commentary for ASME Section III," S. W. Tagart, Jr., EPRI Report NP-5775, April 1988.

4.13 Corrosion Control in the Chemical Process Industries, C. P. Dillon, McGraw-Hill, Inc., 1986.

4.14 Corrosion Data Survey, National Association of Corrosion Engineers, 1974.

4.15 Corrosion Engineering, Mars G. Fontana, McGraw-Hill, Inc., 1986.

4.16 Metals Handbook Desk Edition, American Society For Metals, 1985.

4.17 "Insulation Design Practices For Mitigation Of Pipe And Equipment Corrosion," J. B. Bhavson, Lummus Crest, Inc. Presented at the NACE conference in New Orleans, April 1989. 
4.18 Galvanic Corrosion - Electrochemical Theory of Galvanic Corrosion, Harvey P. Hack, editor, American Society of Testing and Materials, 1988.

4.19 "A Study of Microbiologically-Influenced Corrosion in Nuclear Power Plants and a Practical Guide for Countermeasures," D. Cubicciotti, EPRI Report NP-4582, May 1986.

4.20 Microbial Corrosion in Fossil-Fired Power Plants - A Study of Microbiologically-Influenced Corrosion and a Practical Guide for Its Treatment and Prevention," J. A. Bartz, EPRI Report CS-5495, November 1987.

4.21 U.K. Corrosion 87 Proceedings for meeting held October 26-28, 1987, "The Influence Of Sulphate Reducing Bacteria On Hydrogen Absorption by Cathodically Protected Steel, " published by the Institute of Corrosion Science and Technology, M. J. Robinson, et al., pp. 279-289.

4.22 Microbial Degradation Of Marine Lubricating Oil, R. A. King, et al., The Institute Of Marine Engineers, 1976.

4.23 Stress Corrosion Cracking - Material Performance and Evaluation, American Society of Materials, 1992, Chapters 1 and 4.

4.24 NUREG-1061, Volume 1, Report of the U.S. Nuclear Regulatory Commission Piping Review Committee, August 1984.

4.25 "Proceedings: Workshop on Initiation of Stress Corrosion Cracking Under LWR Conditions," D. Cubicciotti, EPRI Report NP-5828, May 1988.

4.26 "Stress Corrosion Cracking of Alloys 600 and 690 in All - Volatile - Treated Water at Elevated Temperatures," C. E. Shoemaker, EPRI Report NP-5761SP, May 1988.

4.27 Corrosion Of Stainless Steels, Sedricks, John Wiley \& Sons, 1979.

4.28 "Erosion-Corrosion Experiments and Calculation Model," W. Kastner, Kraftwerk Union AG, presented at an EPRI-sponsored Erosion/Corrosion Program, April 1987.

4.29 "Erosion/Corrosion in Nuclear Plant Steam Piping: Causes and Inspection Program Guidelines," N. S. Hirota, EPRI Report NP-3944, April 1985.

4.30 Metallurgy of Welding, J. F. Lancaster, 1980.

4.31 "Investigation of the Condition of Spent Fuel Pool Components, " F.M. Kustas et al., PNL Report PNL-3513, September 1981.

4.32 ANSI/ASME B31.1, "Power Piping," 1989 (Addenda 1989). 
4.33 American Society of Mechanical Engineers Boiler and Pressure Vessel Code, Section ND-2100, 1983.

4.34 American Society of Mechanical Engineers Boiler and Pressure Vessel Code, Section III, Rules for Construction of Nuclear Power Plant Components, Division 1, Subsection ND-3800, "Design of Atmospheric Storage Tanks," 1989 with 1994 addenda.

4.35 American Society of Mechanical Engineers Boiler and Pressure Vessel Code, Section III, Rules for Construction of Nuclear Power Plant Components, Division 1, Subsection ND-3900, "Design of 0-15 psi Storage Tanks," 1989 with 1994 addenda.

4.36 Nuclear Steam Supply Systems Chemistry Manual, CENPD-28, Rev. 2, Combustion Engineering Power Systems.

\section{Other Supplementary References}

- $\quad$ Corrosion Data Survey, Metals Section, NACE, 1981.

- Manual for Determining the Remaining Strength of Corroded Pipelines, a supplement to ANSI/ASME B31 Code for Pressure Piping, ANSI/ASME B31G, 1991 revision.

- $\quad 1987$ EPRI Workshop on Secondary - Side Intergranular Corrosion Mechanisms: Proceedings," J.P.N. Paine, EPRI Report NP-5971, Vols. I and II, April 1987.

- $\quad$ NUREG/CR-4652, Concrete Component Aging And Its Significance Relative to Life Extension of Nuclear Power Plants."

- "Material Specification For Alloy X-750 in LWR Internal Components," EPRI Report NP-6202, January 1989.

- $\quad$ "Proceedings: 1985 Workshop On Primary Side Stress Corrosion Cracking Of PWR Steam Generator Tubing," EPRI Report NP-5158, June 1987.

- $\quad$ Optimization Of Metallurgical Variables To Improper Corrosion Resistance On Inconel Alloy 600," EPRI Report NP-3051, July 1983.

- "Mechanisms Of Stress Corrosion Cracking Of Alloy X-750 In High Purity Water," C. A. Grove, L. D. Petzold, Symposium On Nickel Based Alloys, American Society for Metals, Cincinnati, Ohio, October 1984.

- $\quad$ The Corrosion Handbook, M. H. Uhlig, J. Wiley \& Sons, 1948. 
- $\quad$ NRC Information Notice No. 86-116, Supplement 3-Feedwater Line Break, November 10, 1988. 


\section{EFFECTIVE MANAGEMENT OF AGING MECHANISMS}

Aging mechanisms and their effects must be understood with sufficient accuracy and detail to provide the basis for developing and implementing aging management strategies that address actual or potential root causes of tank/pool failures. The requisite understanding may be either empirical or mechanistic, depending on the nature and potential consequences of a particular aging mechanism. An understanding of degradation requires a detailed awareness of tank/pool design, fabrication, installation, testing, inservice operation, and maintenance cycles. Degradation of tanks/pools is a time-dependent phenomenon that depends on the interactions of materials with environmental and operational stressors.

This section reviews the concept of aging management in three basic steps. First, the basic criteria of what establishes an adequate aging management program are reviewed (Section 5.1). Next, the available plant practices or program elements that may be incorporated into the overall aging management program are identified. These practices will span the range from common (Section 5.2) to less common (Section 5.3). Finally, one or more of the available practices will be selected to form the foundation for adequate management of aging effects (Section 5.4). A graded approach is assured when the component design basis is adequately addressed along with a qualitative risk assessment (i.e., a "do what makes sense" approach). Other considerations that may factor into aging management of some tanks/pools are provided in Section 6.

\subsection{Aging Management Program Considerations}

Sections 3 and 4 described supporting information for the aging management determination. Once the tank/pool aging effects have been identified, an aging management program must be established. In accordance with $10 \mathrm{CFR}$ 54.21,[5.1] the licensee must demonstrate that the effects of aging will be adequately managed so that the intended function(s) will be maintained consistent with the current licensing basis for the period of extended operation. No specific guidance is given, however, as to how this should be demonstrated.

One method of demonstrating adequate management of aging effects is to develop a review checklist with criteria that correspond to the scope of the review for the structure or component. This approach recognizes that there is not just one set of criteria for demonstrating that the aging effects will be managed. The following are considered key elements that may be individually or collectively used to construct an appropriate aging management program.

1. The scope of the program(s) includes the specific structure or component subject to aging management review.

2. The aging effect(s) are specifically or indirectly detected by one or more of the credited programs.

3. The program(s) contains acceptance criteria against which the need for corrective action will be evaluated, and ensures that timely corrective action will be taken when these acceptance criteria are not met. 
4. The program(s) mitigates the aging effects before there is a failure of the applicable system intended function(s).

5. Monitoring and trending provide adequate predictability, as well as timely corrective or mitigative actions.

6. The program(s) is subjected to administrative controls.

7. An analysis of the aging effect(s) has demonstrated that, even if the aging effect is not detected, or managed, the intended function(s) will be maintained.

8. The features of the program(s) assure that the intended function(s) will be maintained independently of any specific knowledge about the aging effects. That is, the periodicity and attributes of the program(s) ensure early and adequate detection of the aging effects or failure, and mitigation by corrective action or implementation of an alternate way to accomplish the intended function(s).

If all the elements of the aging management program cannot be satisfied, then appropriate enhancements may be needed. Such enhancements may include, but are not limited to, verification of specific design values by one-time inspections, adding steps to a procedure for the specific aging effects, changing the frequency of a required task, adding specific aging effects mitigation procedures, and/or changing record-keeping requirements. The factors that should be considered in determining appropriate enhancements are:

- The nature of the aging effect (i.e., is it apparent or easily detected?),

- The feasibility of repair and/or replacement of the affected component following failure,

- The compatibility or adaptability of existing programs to detect and manage the aging effect(s),

- The existence of technology to detect and manage the aging effect(s), and/or

- The estimated cost, personnel radiation exposure, and impact on scheduled normal outage durations for affecting the enhancement.

\subsection{Common Maintenance and Surveillance Techniques/Program(s) Used}

Many tanks/pools are subject to a variety of inspection, test, replacement, and/or refurbishment programs to address diverse functional requirements and various aging mechanisms. To adequately manage the effects of aging, several different programs may be required for a given tank/pool. Through a combination of such programs, the basis for safe and reliable operation throughout the tank/pool's entire service life can be established. 
The following is a discussion of the commonly used maintenance and surveillance programs determined to be effective in detecting aging mechanisms and mitigating the degradation of tanks/pools within acceptable limits.

\subsubsection{ASME Section XI Inservice Inspection Program}

Section XI of the ASME Boiler and Pressure Vessel Code[5.2] provides the rules and requirements for inservice inspection, repair, and replacement of Class 1,2 , and 3 pressureretaining components, including tanks/pools. All tanks evaluated in this aging management guideline are either Class 2, 3, or Non-Class. There were no Class 1 tanks/pools identified since Class 1 components are part of a high pressure system and are classified as pressure vessels. Class 2 and 3 refer to components constructed in accordance with the rules of ASME Section III. Section XI categorizes the areas subject to inspection and defines responsibilities, provisions for accessibility, examination methods and procedures, personnel qualifications, frequency of inspection, record-keeping and reporting requirements, procedures for evaluating inspection results, disposition of results, and repair requirements. Section XI, Article IWC applies to Class 2 components and Article IWD applies to Class 3 components.

ASME Section XI does contain requirements for tanks (atmospheric and 0 to $15 \mathrm{psi}$ tanks). However, ASME Section XI does not contain requirements for pools within the scope of this AMG.

Most tanks subject to the requirements of ASME Section XI are classified as ASME Class 3 (Quality Group C). Some are ASME Class 2 (Quality Group B). Most of these tanks, whether Class 2 of 3 , are exempt from the periodic examination requirements (e.g., nondestructive examination (NDE)) of ASME Section XI because most tanks operate at temperatures and pressures less than threshold values set in IWC-1222(c) and IWD-1220(c). If not exempt, the extent of the periodic examination requirements generally includes visual (VT-3) examination of the component supports and restraints that are associated with the tank. All tanks subject to ASME Section XI requirements (exempt or nonexempt) are required to be pressure tested as part of the system in which they are installed. These pressure testing requirements include a system leakage test and, in some cases, a hydrostatic test.

System Leakage Test

The system leakage test is conducted on a 40-month frequency at the nominal operating pressure of the associated system.

System Hydrostatic Test

A system hydrostatic test is required to be conducted once every ten years.

In the case of atmospheric storage tanks, the nominal hydrostatic pressure developed with the tank filled to its design capacity is acceptable as the system test pressure. A visual (VT-2) examination for pressure-retaining components to check for evidence of leakage is required during the pressure test. (See ASME Section XI, IWC-5230(b), or equivalent.) 
In the case of 0 to 15 psi storage tanks, the nominal hydrostatic test pressure is required to be $110 \%$ of the design pressure of the vapor space above the liquid where the design temperature is less than $93^{\circ} \mathrm{C}\left(200^{\circ} \mathrm{F}\right)$. A visual (VT-2) examination for pressure-retaining components to check for evidence of leakage is required to be performed on the tank during the pressure test.

As an alternative to the 10-year system hydrostatic testing specified in ASME Section XI for Class 2 (IWC-5230(c)) and Class 3 (IWD-5222(c)) tanks, ASME Code Case N-498-1 allows a system pressure test conducted at the nominal operating pressure.[5.3]

Plant Technical Specifications and 10 CFR 50.55a[5.4] require a program for the inspection of ASME Class 1, 2, and 3 components in accordance with the requirements of the ASME Boiler and Pressure Vessel Code, Section XI.[5.2] The components that are a part of this program are listed in the plant's ISI Plan.

As required by $10 \mathrm{CFR} 50.55 \mathrm{a}$, every 120 months (10 years) the Inservice Inspection Plan is reviewed and revised to meet the latest edition of the ASME Boiler and Pressure Vessel Code. This revision is submitted to the NRC for approval. Between these revisions, changes may be made to the plan as a result of changes to the components in the plan, additional relief requests, etc. All changes require NRC approval.

The ISI program is designed to detect the existence of flaws (cracks) in Class 1,2 , and 3 piping systems and components, and to monitor crack growth to ensure that crack sizes do not exceed the requirements of Section XI of the ASME Boiler and Pressure Vessel Code. Methods to detect cracks include visual and NDE techniques. Pressure testing to the requirements of Section XI is also administered by this program.

\subsubsection{Preventive Maintenance Program}

Preventive maintenance (PM) is defined as periodic, predictive, or planned activities performed on a tank/pool before its failure or removal from service. The objective of conducting PM is to sustain or extend the service life of a tank/pool by controlling degradation and failures to an acceptable level.

Periodic maintenance activities are performed on a routine basis (typically based on operating hours, number of cycles, or calendar time). For tanks, these activities include such actions as replacement of gaskets and other renewable components, verification of fastener torque, and inspections for external leakage and/or other abnormal conditions.

Predictive maintenance activities involve continuous or periodic condition monitoring of tank operating parameters (e.g., level, lost or spilled contents, pressure) and/or functional performance testing of the tank/pool. Elements of predictive maintenance include data gathering, analysis, diagnosis, and trending to determine the material condition and performance characteristics of the tank. Typical predictive maintenance activities associated with tanks/pools include monitoring of level, ullage measurements, vibration and pressure loss, eddy current testing, and leak testing. 
Planned maintenance activities are scheduled on the basis of information obtained and trends derived from performing periodic and predictive maintenance. These activities are conducted before tank/pool failure and consist of inspections, refurbishment, overhaul, and major part replacement. Also, planned maintenance activities can be identified and initiated based on vendor recommendations, industry operating experience, and plant-specific operating and maintenance history.

The PM program is governed by approved administratively controlled documents and is conducted in accordance with detailed implementing procedures. PM plans are developed to outline task requirements and to coordinate scheduling and implementation of PM activities associated with all plant equipment covered by the program, including tanks/pools. The frequency for performing PM is dependent upon engineering assessments, plant/industry operating experience, environmental conditions, manufacturers' recommendations, and feedback from maintenance personnel.

Completed PM activities are reviewed by cognizant personnel. The results are compared with acceptance criteria and timely corrective actions are initiated as appropriate. Data is extracted from the completed PM and analyzed for the purpose of detecting adverse trends. The frequency of performing a PM activity may be increased or decreased depending upon the observations made and conclusions drawn from review of the completed PM activity.

\subsubsection{Microbiologically Influenced Corrosion (MIC) Control Program}

Proper diagnosis is particularly important in situations where MIC is suspected because treatment can be expensive in terms of time, equipment, materials, and environmental impact. Background information such as materials of construction, fabrication methods, and operating history can yield significant insights into potential microbiological influences. Examples of operating history are source of water, types of water treatment, lay-up methods, and operating characteristics (i.e., stagnation, low flow, intermittent operation, and operating time).[5.5]

\subsubsection{Water Sampling}

Sampling of the water at the source and immediately upstream and downstream from the tank/pool quarterly is sufficient to assess seasonal variations in microbial content, oxygen, and critical nutrients. A complete water analysis will assist in separating corrosive effects of the water from microbial influence. Sampling of the water at these locations is useful to:

- Identify heavily infested areas requiring further investigation.

- Evaluate the effectiveness of biocide treatments.

- Locate areas where microbes may be reproducing rapidly.

- Detect trends over time to focus sampling points.[5.5] 


\subsubsection{Solid Sampling}

When the tank/pool is opened for maintenance purposes, areas of interest should be visually examined and solid samples removed for detailed chemical and microbiological examination. Typically, deposits, tubercles, or volumes of corrosion products in the vicinity of the corrosion site are the areas where the samples should be removed for analysis. Additional visual examination of the under deposit area and removal of metal samples for metallurgical analysis may be appropriate. MIC leaves a particular set of chemical fingerprints. When a sample exhibits very low organic content, and where essentially no enrichment in sulfur or chloride is noted (as compared to the base metal and/or water analysis), MIC is not likely to have been a contributor to the corrosion. [5.5]

\subsubsection{Treatment}

Treatments to control MIC fall into three general categories: mechanical cleaning, chemical treatment, and engineering and operational controls.[5.5]

Mechanical Cleaning

Mechanical cleaning methods are used to physically remove deposits from material surfaces. In this way, impediments to flow are removed. Since MIC is always associated with biofilms on metal surfaces, the first objective is to remove the film. In some cases, these biofilms are extremely difficult to remove with biocides or corrosion inhibitors; therefore, mechanical cleaning methods must be applied. When the tank/pool is opened for maintenance and after the solid samples have been removed, hydrolyzing and/or steam lancing can be performed to remove deposits and tubercules. Abrasive particles (i.e., sandblasting) can be used on the tank/pool shell surfaces; however, a disadvantage with this method is the collection and cleanup of the material.

\section{Chemical Treatment}

Chemical water treatments include the use of biocides, corrosion inhibitors, and dispersant. Biocides may be oxidizing or non-oxidizing agents with injection to the fluid stream made on a continuous basis or scheduled as a batch/slug process. Biocides can be used in combination to increase their effectiveness, decrease effluent concentrations, or reduce costs. Biocides may be used in conjunction with dispersants to prevent accumulation of deposits. Inhibitors may be used independently or with biocides or dispersant for corrosion control.

Oxidizing biocides, particularly chlorine, are the most commonly used agents for MIC control. Economics, simplicity of use, and the vast experience base are the overriding considerations for the use of chlorine. Depending on water and solid sample analysis results, other oxidizing biocides such as chlorine dioxide, bromine compounds, ozone, and/or hydrogen peroxide may be used. Non-oxidizing biocides that may be used are acrolein, glutaraldehyde, isolthiazonline, and quartenary ammonia compounds. 
Used in conjunction with biocides, dispersants help to remove organisms killed by the biocidal treatment along with nutrients and debris that may have become attached to the biofilm. Dispersants keep such materials suspended in the fluid stream.

Corrosion inhibitors, such as chromates, have biocidal properties and can be effective in the treatment of MIC provided the biological growth has been removed from the tank/pool surfaces either mechanically or chemically and the microbial infestation has been controlled. Corrosion inhibitors are used primarily in the closed cooling water systems.

If large amounts of fungal contamination exist in a system, the fluid should be drained and discarded before a biocide is added to the system. The filters on the tank should be checked frequently after first adding biocide to the fluid since the biocide will kill the fungus, releasing dirt and rust that may have been caught in the fungus mat. After the fungus is killed, its filterability will increase because it will lose its slippery quality. The biocide should be applied to a partially filled tank, and then the tank should be filled completely. The filling action mixes the fluid and biocide and provides an even concentration of mix throughout the tank. Biocide should not be added to partially filled tanks unless the intent is to fill the tank in the near term.

Engineering and Operational Controls

Engineering and operational controls may involve draining and drying tanks during outages. Engineering controls may include modifications or high temperature treatment.

For carbon steels and copper alloys, where sulfate-reducing bacteria activity is high, intermittent flow provides cyclic oxidation and can produce the worst case corrosion situation. For stainless steels, intermittent flow conditions are preferable to stagnation because the attachment of bacteria to tank/pool surfaces is minimized, thereby reducing the effects of MIC.

It may be possible in some tank applications to design and install sacrificial anodes to cathodically protect the tank/pool subcomponents from MIC and other corrosion forms. The size and location of the sacrificial anode, as well as the anode material, must be selected in such a way that the protective current density on any location is larger than the corrosion current density. Common shapes of sacrificial anodes include bars, plates, cylinders, and ribbons. Most of the anodes for application in water are cast with a galvanized steel core, wire, or strap to facilitate welding or bolting.

\subsubsection{Diesel Fuel Oil}

Several forms of fungi and other microorganisms can survive and multiply in hydrocarbon fuels. The microscopic growths occur in all areas of the fuel handling system-storage tanks, pump trucks, delivery lines, and fuel tanks. These fungi grow into long strings, and form large mats or globules. The growth appears slimy, and is usually black, green, or brown, although it may be any color. It may grow throughout the fuel, or at the interface area between the fuel and water bottom layer. As the fuel is agitated, for instance during filling, fungal growth is distributed throughout the fuel system. The fungi and organisms need only trace amounts of minerals and water to sustain their growth, and use the fuel as their main food source. Their growth chemically alters the fuel by producing sludge, acids, and other 
by-products of metabolism. When they adhere to the fuel-containing surfaces, the water and waste products lead to corrosion. Rubber and other tank linings, hoses, and coatings may be consumed due to the energy and trace minerals composition present in the rubber lining, hoses, or coatings. Such contamination can be controlled in a two-step process:

(1) use of a proven biocide with dispersant, and

(2) regular cleaning and inspection of storage tanks.[5.6]

\subsubsection{Other Licensing Basis Programs}

Each nuclear power plant has an established licensing basis that provides an infrastructure for plant operation, testing, inspection and maintenance. The infrastructure provides reasonable assurance that public health and safety will not be impacted. The exact licensing basis varies from plant to plant and depends largely on the vintage of the plant (i.e., time period of issuance of original operating license). Certain elements of this licensing basis are generic to nuclear plants and serve as elements of an overall tank or pool aging management program. These elements are discussed individually in the sections that follow.

\subsubsection{Quality Assurance Program (10 CFR 50.34)}

10 CFR 50.34[5.4] requires nuclear power plants to implement a Quality Assurance Program to the requirements outlined in 10 CFR 50, Appendix B.[5.4] The requirements of this program typically are implemented through the use of site procedures, inspections, directives and manuals.

The Quality Assurance Program requires that activities affecting plant safety be conducted in a controlled manner with processes approved by, and results periodically audited by, an independent Quality Assurance organization. Such an approach assures that the quality of design, construction, test, or any other activity performed remains high, thereby providing reasonable assurance that systems, structures, and components will continue to perform their intended functions in a satisfactory manner.

While a licensee's Quality Assurance program does not in and of itself constitute aging management, it does provide a strong foundation for control of the many activities that do.

\subsubsection{Technical Specifications (10 CFR 50.36)}

Plant technical specifications are required by 10 CFR 50.36.[5.4] Plants conduct a regular, rigorous functional testing and surveillance program for all safety-related systems. The requirements provide assurance that the plant is operated and maintained within the bounds established by the analyses and evaluations presented in the FSAR. The contents of technical specifications were established during initial plant licensing and have been revised many times over the years. The revision process is governed by 10 CFR 50.90, .91, and .92.[5.4] Each revision must be proposed by the licensee and approved by the NRC staff. Once approved by the staff, the revision is issued as an amendment to the operating license. 
The requirements of the technical specifications are implemented by plant procedures. The development and control of these procedures is governed by the Administrative Controls section of the technical specifications. Several specific programs are required by the Administrative Controls section with only high-level programmatic requirements contained in the technical specifications and the details contained in the plant implementing documents.

Systems, structures, and components (SSCs) contained in technical specifications are generally safety-related and are either explicitly or implicitly identified. These SSCs are required to be operable. Operable is a defined term of technical specifications that requires "that all essential auxiliary equipment required in order to assure performance of the safety function is capable of performing its related support function(s)."

Most of the SSCs covered in technical specifications are covered under the plant maintenance program. Should adverse performance trends be detected as a result of required surveillances, appropriate corrective action would be required.

Technical specification surveillance tests require the successful operation of passive longlived components and testing of all portions of the system equally. For example, functional testing typically verifies that the system pressure boundary is intact (including all components required to perform the tested function), that the electrical components have maintained continuity of power supply, and that component supports have maintained structural integrity. Deviations from performance criteria and abnormalities are subject to condition reporting and cause evaluation, root cause analysis or reporting to assure that system performance is restored, recurrence is minimized, and potential applicability to other systems or components is addressed.

Tank/pool level and temperature monitoring are typically conducted as a Technical Specification Surveillance requirement, whereby failure to maintain level/temperature would result in a Limiting Condition of Operation (LCO). Specific tanks with technical specification level monitoring include diesel fuel oil tanks, boric acid storage tanks, the refueling water storage tank, and the condensate storage tank.

Failure to remedy the loss of integrity within the prescribed LCO time limit in most cases would initiate a plant derate and a performance input against the applicable system (Maintenance Rule consideration-Section 5.2.4.3). The tank/pool failed function would then be subject to a Maintenance Preventable Functional Failure (MPFF) review to assess if the failure is a common cause or a repetitive failure.

\subsubsection{Maintenance Rule (10 CFR 50.65)}

The Maintenance Rule, "Industry Guideline for Monitoring the Effectiveness of Maintenance at Nuclear Power Plants," 10 CFR 50.65,[5.4] requires that utilities assure maintenance effectiveness through performance or condition monitoring. The performance measurements are typically based upon availability and/or reliability and can be applied at either a plant, system, or train level. Due to the similarity of the scopes covered under the MR and LRR, essentially all of the systems within the scope of license renewal are also addressed by the Maintenance Rule. 
Systems which do not meet the established performance criteria require goal setting and further scrutiny. If an active or passive component failure occurs that results in the loss of a system intended function, a cause evaluation is required to establish if the failure was maintenance preventable. Additionally, a review is required of other similar failures to determine if the failure is a common cause or repetitive maintenance preventable failure. In such cases, comprehensive root cause analyses are conducted to prevent recurrence in other components or systems and to implement corrective and preventive measures.

The Maintenance Rule addresses tanks/pools from a system function viewpoint. Tank functions typically are "to maintain level" and "to maintain temperature levels (either to not freeze or to maintain chemical solution levels)." Failure to maintain tank integrity would prevent the tank from performing its intended function: providing or transferring adequate fluid inventory when demanded by the system.

When tank/pool performance falls below established goals, goal setting, corrective actions, and increased monitoring will be required to return the tank/pool to an acceptable level of performance.

\subsubsection{Plant Problem Notification (10 CFR 50.72 and 73)}

10 CFR 50.72, "Immediate Notification Requirements for Operating Nuclear Power Reactors" (Section (2)(iii)), and 10 CFR 50.73, "Licensee Event Report System" (Section (v)(A)),[5.4] require any event or condition that could have prevented the fulfillment of the safety function of structures or systems needed to shut down the reactor, remove residual heat, control the release of radioactive material, or mitigate the consequences of an accident be promptly reported to the NRC. Failure of a tank/pool to provide or support a safety function when its availability is required may have to be reported.

To ensure compliance with these requirements, utilities have in place an event/issue reporting and evaluation program that evaluates plant events/issues for potential reportability. This program ensures that all plant events/issues receive an adequate level of review and analysis (e.g., root cause, consequences, etc.) as appropriate. Important inputs to this program are issues reported via the plant's Quality Assurance program (Section 5.2.4.1) or the plant's Operational Feedback Experience program (Section 5.2.4.5).

\subsubsection{Feedback of Operating Experience (TMI Action Item I.C.5)}

A result of the Three Mile Island (TMI) accident was a requirement for each utility to institute an operating experience assessment program that involves utility personnel having collective competence in all areas important to plant safety (TMI Action Item Number I.C.5 of NUREG-0737).[5.7] Therefore, it is important that procedures exist to assure that important information on operating experience originating both within and outside the organization is continually provided to operators and other personnel and that information is incorporated into plant operating procedures and training programs as appropriate.

Those involved in the assessment of operating experience will review information from a variety of sources. These include operating information from licensee's own plant(s), 
publications such as IE Bulletins, Circulars, and Notices, and pertinent NRC or industrial assessments of operating experience. In some cases, information may be of sufficient importance that it must be dealt with promptly (through instructions, changes to operating and emergency procedures, issuance of special precautions, etc.) and must be handled in such a manner to assure that operations management personnel would be directly involved in the process. In many other cases, however, important information will become available which should be brought to the attention of operators and other personnel for their general information to assure continued safe plant operation.

\subsubsection{Boric Acid Corrosion Monitoring Program (Generic Letter 88-05)}

NRC Generic Letter 88-05[5.8] addresses the corrosive effects of boric acid leaks on PWR carbon steel reactor coolant pressure boundary components. This issue initially focused upon the potential loss of carbon steel from reactor coolant pressure boundary components inside the containment due to accelerated corrosion caused by boric acid leakage. However, many utilities have expanded the scope of this program or have created similar programs to identify and correct boric acid leakage where it may negatively impact other carbon steel or low alloy steel surfaces or components. Such a program could contribute directly to the aging management of certain tanks and pools that contain carbon steel or low alloy steel pressure boundary components and are in the vicinity of boric acid containing systems.

PWR tanks within the scope of this AMG that are in direct contact with boric acid and which may be addressed by this program include the following:

- Boric Acid Storage Tanks

- Refueling Water Storage Tanks

- Volume Control Tanks

- Spent Fuel Pool

In most cases, these tanks will be constructed entirely of stainless steel. However, low alloy steel and even carbon steel bolting components (studs and nuts) used for flanged connections and manway hatch covers are common and may be susceptible to boric acid related corrosion.[5.9]

\subsubsection{Raw Water Program (Generic Letter 89-13)}

NRC Generic Letter 89-13[5.10, 5.11] addresses biofouling, erosion, and corrosion concerns in open cycle service water systems using raw (untreated) water and its impact on the system's ability to perform its function of transferring heat from reactor plant safety systems to the ultimate heat sink. Concerns over biofouling, however, encompass all systems that use raw water which, for most utilities, would include fire protection systems that draw upon site wells or store untreated water.

Biofouling and related microbiologically influenced corrosion are the main failure causes encountered in raw water systems. Chemical treatments with chlorine compounds and visual monitoring are the most frequently prescribed actions for mitigating the effects of the fouling and corrosion for components exposed to raw water. Section 5.2.3 described a MIC control 
program that should include systems using raw water to limit the corrosive damage incurred when microbiological growth is not controlled. An example of a tank within the scope of this AMG that may be included within a Raw Water MIC control program is the fire water storage tank.

\subsubsection{Diesel Fuel Oil Tank Requirements (NRC Regulatory Guide 1.137)}

NRC Regulatory Guides present acceptable methods of demonstrating compliance to federal regulations such as those described in Section 6.2. Regulatory Guide 1.137[5.12] ensures the proper quality of fuel oil used to fuel the standby diesel generators. It states for "buried supply tanks not located within a vault and other buried portions of the system, a protective coating and an impressed current-type cathodic protection system should be provided...." If a cathodic protection system is to be used "the impressed current-type cathodic protection system should be designed to prevent ignition of combustible vapors or fuel oil present in the fuel-oil systems for standby diesel generators." The Regulatory Guide provides guidelines for creating an acceptable method for meeting the requirements of Section XI: (1) pressure testing of the fuel-oil system at 10-year intervals, and (2) a visual inspection conducted during the pressure test for evidence of component leakages, structural distress, or corrosion. In the case of buried components, a loss of system pressure during the test constitutes evidence of component leakage.

Tanks within the scope of this AMG that may be addressed by Regulatory Guide 1.137 include the following:

- Diesel Fuel Storage Tanks

- Diesel Fuel Day Tanks

\subsubsection{Spent Fuel Pool Requirements (NRC Bulletin 94-01)}

NRC Bulletin 94-01[5.13] was issued to address concerns over spent fuel pool integrity. The most important safety function of the spent fuel pool is to maintain an adequate inventory of water in the spent fuel pool to safely cool and store spent fuel. A proper depth of water provides protection for plant personnel from excessive exposure to radiation from spent fuel and other materials stored in the spent fuel pool. Control of the exposure of plant personnel is required by 10 CFR 20.[5.14]

Rapid loss of spent fuel pool water may result from a failure of piping or from a siphoning action as a result of an improper valve alignment. A loss of spent fuel pool water may also result from a failure of seals or gaskets used as part of the spent fuel pool boundary. If seals and gaskets are allowed to become degraded, a leak may increase rapidly once it initiates. Leak chase systems have been installed to prevent loss of inventory due to degradation and failure of the spent fuel pool liners. The lack of a leak detection system or a water inventory management program may allow leakage of spent fuel pool water to go undetected.

Proper maintenance and operation of spent fuel pool systems is necessary to maintain water quality and radionuclides at acceptable levels. Maintenance of water quality is necessary to prevent degradation of the spent fuel and other materials stored in the spent fuel pool (i.e., 
control rod blades or incore instrument strings). Proper spent fuel pool water treatment programs prevent the buildup of excessive concentrations of radionuclides. Proper maintenance of the spent fuel pool and the support systems would also mitigate the consequences of any potential release from the spent fuel pool.

NRC Bulletin 94-01[5.13] requested the following actions to ensure that the quality of the spent fuel pool coolant and the cooling and shielding for fuel or equipment stored in the spent fuel pool is not compromised and that all necessary structures and support systems are maintained and are not degraded.

1. Verify that the structures and systems required for containing, cooling, cleaning, level monitoring and makeup of water in the spent fuel pool are operable and adequate, consistent with the licensing basis, to preclude high levels of radionuclides in the pool water and adverse effects on stored fuel, the spent fuel pool, fuel transfer components, and related equipment.

2. Ensure that systems for essential area heating and ventilation are adequate and appropriately maintained so that potential freezing failures that could cause loss of spent fuel pool water inventory are precluded.

3. Ensure that piping or hoses in or attached to the spent fuel pool cannot serve as siphon or drainage paths in the event of piping or hose degradation or failure or the mispositioning of system valves.

4. Ensure that operating procedures address conditions and observations that could indicate changes in spent fuel pool level and address appropriate maintenance, calibration, and surveillance of available monitoring equipment. This should include any leak detection systems.

\subsubsection{Plant-Specific Regulatory Commitments}

The previous discussions relative to plant current licensing basis have been generic to all plants (GL 88-05 applicable to PWRs only). It must be recognized, however, that each plant is unique not only in design, operation, and methods of management but also in terms of what constitutes the current licensing basis. When the full spectrum of plant-specific regulatory commitments embodied in the Updated Final Safety Analysis Report, Operating License, Technical Specifications, NRC Safety Evaluation Report, and utility responses to all applicable NRC Generic Letters, Information Notices, Bulletins and Circulars are considered, the uniqueness of each plant is clearly evident. These unique differences should be accounted for when identifying the scope of applicable program elements for use in the overall aging management program as discussed in Section 5.4.

\subsubsection{Operator Activities}

Operators routinely tour the plant (i.e., operator walkdowns) to observe tank/pool conditions and record results on a checklist that contains qualitative and quantitative acceptance criteria. Individual checklist activities are performed at various frequencies ranging from hourly 
to monthly. The frequency is established based on experienced rates of change or degradation potential for the observed item. If acceptance criteria are not met, the operators inform the shift supervisor, who initiates appropriate corrective or investigative action.

The annunciator response procedure prescribes the actions that operators must take in response to individual automatic alarms. When degradation causes a change in system or component operating parameters, and that parameter is monitored by an automatic alarm, the operator will take specific actions in response to the alarm. If the operator cannot correct the alarmed condition (e.g., tank/pool level below required levels), the operator reports the condition to the shift supervisor, who initiates appropriate corrective or investigative actions. For most operating tanks/pools, alarms are activated before the limiting criteria are exceeded. This allows time to evaluate, correct, or transfer fluids to a standby tank/pool without impacting plant operations.

Low-pressure tanks (i.e., those within the scope of this AMG) rarely have a catastrophic failure without first showing warning signs. A fluid puddle on the ground would indicate a potential problem exists and this information would be forwarded to responsible personnel. Determining the problem, the remedy and the required time to fix the problem would then be determined.

All tanks/pools within the scope of this AMG are subjected to some form of routine inspection by plant personnel and level monitoring (automatic in most cases, manual in others).

\subsubsection{Protective Coatings Program}

There are several different generic coating types commonly used in industry. Coatings isolate the surfaces of the tank system from the environment (external) and process fluid (internal), thereby minimizing potential degradation. Coated and cathodically protected steel tanks are in wide use and are reported to have high reliability. Dielectric coatings isolate the surfaces of the tank system and reduce the electric current demand on the cathodic protection system required to obtain the desired protection levels throughout the life expectancy of the tanks.[5.15] The coating types and a brief description of each are listed below [5.16]:

1. Alkyds:

Also known as oil-based paints, alkyds are one of the most widely used types of coatings. Alkyds are normally used in mild environments.

2. Acrylics:

Acrylics are synthetic resins, known for their appearance retention in mild environments.

3. Epoxies:

Epoxies are typically supplied as two components that require mixing before application. Corrosion and chemical resistance are better than for alkyds or acrylics. 
4. Polyurethanes:

Polyurethanes are also typically two-component products. Their versatility offers a wide range of characteristics from high-gloss, thin-film coatings to high-build, thick-film waterproofing membranes.

5. Vinyls:

Vinyls are based on synthetic resins and exhibit good overall chemical resistance and flexibility.

6. Zinc-rich silicates:

Zinc-rich silicates, typically used as primers, offer the same level of corrosion protection as hot-dipped galvanizing.

Periodic walkdowns and inspections of tank surfaces ensures that visible degradation will be detected before significant damage to the tank/pool. Coating programs aid in maintaining the tank surfaces to reduce the potential for undetected age-related degradation. Only approved coatings may be used for each specific application. These typically are specified in applicable coatings programs. Surface cleaning and preparation are also specified.

The durability of a tank/pool coating is related to the preparation of the surface to which the coating is applied. For industrial use, the Steel Structures Painting Council has categorized various grades of surface preparation. Coatings have a "practical life," defined as the time required until 5 to 10 percent breakdown of the surface area occurs, active rusting of the substrate occurs, and rust grade 4 is present.[5.17] Rust grade 4 is rusting to the extent that 10 percent of the surface is rusted.[5.18] Depending on surface preparation, a twocoat alkyd system would have a practical system life of 3 to 6 years; a two-coat epoxy system would have a practical system life of 7.5 to 12 years; and a two-coat epoxy/urethane would have a practical system life of 9 to 10.5 years. An optimal schedule calls for the tank/pool surfaces to be cleaned and recoated after a 3 to 5 percent breakdown of the topcoat occurs, which is before rusting begins.

In some cases (e.g., asphaltic or painted coatings), separations of the coating from the tank ("holidays") will occur. Without a cathodic protection system, all of the galvanic forces will be focused on the holiday, causing rapid corrosion and subsequent release of the tank fluid. Dielectric coatings should enhance the operation of the cathodic protection system by reducing its electric current demand. The cathodic protection system, in turn, will protect the coated underground storage tank (UST) from corrosion at holidays. To ensure structural integrity, the cathodic protection system must be inspected and maintained according to the operation and maintenance procedures.

\subsection{Less Common Maintenance and Surveillance Techniques/Programs Used}

This section discusses some of the less common maintenance and surveillance programs effective in detecting and mitigating aging mechanisms of tanks/pools to within acceptable limits. 


\subsubsection{Lay-up Programs}

Historically, lay-up practices have been applied on a random basis. System and component level lay-up activities should be scheduled and performed so that station personnel are used effectively. Rigorous implementation of plant lay-up procedures will result in enhanced equipment preservation, personnel dose reduction, improved water chemistry, and faster plant start-up.

Condition assessments provide the bases for a plant lay-up program and should be used to monitor effectiveness of lay-up methods. In addition to refining lay-up procedures, condition assessment will ensure that component performance and functional requirements are met during plant operation.

A practical and convenient lay-up method for tanks/pools and their associated systems should address several criteria:

- It must be practical to continuously circulate the lay-up fluid.

- Where dry lay-up is used, it must be practical to purge the fluid from the system in a reasonable amount of time, and the volume of the fluid must be stored or processed.

- The lay-up practices should be flexible so that maintenance access can be achieved easily.

- Existing access openings should be used to the maximum extent possible.

- The appropriate lay-up method should be fast and easy to implement.

There are several different types of lay-up methods that can be used. The length of the outage time and scheduled maintenance activities to be performed on the particular tank/pool and/or associated system will dictate the most appropriate and cost-effective lay-up method to be implemented.[5.5] The following subsections describe typical lay-up methods.

\subsubsection{Dry Lay-up Method}

The dry lay-up method is the most flexible approach for accommodating maintenance during outages because the lay-up fluid (i.e., air) is not hazardous. The tank and/or associated system should be rapidly drained and purged with air such that internal surfaces are dry and the atmosphere is well below saturation. Recent advances in desiccant air dryer technology have increased the attractiveness of this method by lowering the cost of high-volume dry air. [5.5]

\subsubsection{Wet Lay-up Method}

To implement wet lay-up, the tank and/or associated system is completely filled with water or filled with water and an overpressure gas such as nitrogen. Normally, some method 
of water circulation is used to facilitate the homogeneous mixing of the chemicals used to treat the water.

In some applications, hydrazine, which is an oxygen scavenger, may be used to treat the water. Higher than normal concentrations of chlorine may be maintained in raw water systems. Corrosion inhibitors, such as chromates in closed cooling water systems, can be considered a form of wet lay-up. Any chemical addition for the purpose of corrosion control in wet lay-up must be approved by plant chemistry department personnel.[5.5]

\subsubsection{Nitrogen Lay-up Methods}

The nitrogen lay-up method entails draining the tank and/or associated system, connecting a nitrogen supply, and purging the space with a volume of nitrogen $\left(\mathrm{N}_{2}\right)$ approximately four times the space's volume. After filling, the tank and/or system is isolated and the nitrogen supply regulators are set to maintain a slightly positive pressure.

It is extremely important to note that a nitrogen environment can result in asphyxiation. Therefore, adequate safety precautions are necessary to prevent personnel access into lay-up regions, where nitrogen accumulation could occur, until adequate ventilation has been provided. Checks for oxygen deficiency should be performed in these areas before entry.[5.5]

\subsubsection{4 "No Treatment" Lay-up Methods-Drained and Left "As Is"}

In the drained lay-up condition, the tank/pool is allowed to drain. For this method, the volume of drained water must be stored or processed. Subsequent to draining, the equipment is exposed to moisture-laden air and/or water in contact with air. Under this environment, corrosion of unprotected carbon steel can be severe.

In the "as is" lay-up condition, the tank/pool and/or associated systems remain without any special treatment after being isolated. System tanks/pools that normally process deoxygenated fluids will remain moderately non-corrosive as long as the tank/pool and/or system is kept isolated. For carbon steel system tanks/pools that normally process raw water or demineralized water containing a high oxygen content, the corrosion process will proceed at a decreasing rate, provided a fresh source of oxygen is not allowed ingress to the system (i.e., the system remains isolated). This happens because, as the corrosion process progresses, the oxygen reacts with the carbon steel to form iron oxide that results in less oxygen available to continue the corrosion process. [5.5]

\subsubsection{Control of External Corrosion on Underground Systems}

Most tanks within the scope of this AMG are above-ground storage tanks. Of the approximately 50 tanks evaluated at the host utility sites, only one was a below-ground tank. The underground environment presents unique challenges to pressure boundary integrity that require unique methods of protection.

National Association of Corrosion Engineers (NACE) RP-01-69[5.19] presents practices for the control of external corrosion on buried or submerged piping systems. Metallic 
structures buried in soil are subject to corrosion and adequate protective measures should be taken to minimize that corrosion. The two main principles of corrosion control presented in this AMG are coatings and cathodic protection. These are common practices but are included in the less common section due to the limited applicable population of tanks/pools in the scope of this AMG.

Coatings should have the following characteristics:

- effective electrical insulator,

- effective moisture barrier,

- ability to resist development of holidays (i.e., localized discontinuities) with time,

- ability to maintain substantially constant electrical resistivity with time, and

- resistant to disbonding when under cathodic protection.

See Section 5.2.6 for further description of coatings.

The major objectives of cathodic protection systems are:

- deliver sufficient current to the structure to protect it and distribute this current so that the selected criterion for cathodic protection is efficiently attained,

- minimize the interference currents on neighboring underground structures,

- provide a design life for the anode system commensurate with the required life of the protected structure,

- provide adequate allowance for anticipated changes in current requirements with time, and

- placement of anodes where the possibility of disturbance or damage is minimal.

Two types of cathodic protection systems exist: galvanic anode systems and impressed current systems. Galvanic anodes can be of materials such as magnesium, zinc, or aluminum. These are installed in the soil or water either bare or packaged in a special backfill and connected to the pipe with an insulated conductor. Impressed current anodes can be of materials such as graphite, high silicon cast iron, lead-silver alloy, platinum, or scrap steel. Impressed current anodes are installed in the soil or water either bare or in special backfill material and connected to the pipe with an insulated conductor. Systems that lack a source of external power would most likely preclude the use of an impressed current system. Systems where stray currents cause significant potential fluctuations between the structure and earth would most likely preclude the use of galvanic anodes.[5.19] 
Other considerations associated with a cathodic protection system are presented in Section 6.

\subsubsection{Tank Bladder/Diaphragm Programs}

Most tanks within the scope of this AMG (evaluated at host utilities) utilized a nitrogen cover gas where chemistry control (e.g., deoxygenation) was a function of the tank. There are some tank applications where an internal bladder or diaphragm is used to minimize oxygen absorption. These bladders/diaphragms are typically made of reinforced rubber and sometimes a floating roof and are designed to collapse or contract as the tank level is reduced to prevent air entering the tank vents from coming in contact with the contained liquid. Bladders/diaphragms, therefore, are installed for chemistry control only and are not related to the pressure boundary integrity of the tank (other than indirect corrosion prevention through chemistry control). In other words, the bladder/diaphragm will generally not be related to a tank intended function as defined in Section 3.

Tanks with bladders/diaphragms may require a higher level of direct tank maintenance and inspection. This is due to the added subcomponent (the bladder/diaphragm) being the limiting component in terms of tank "system" life. As such, bladders/diaphragms will likely require more frequent inspection to ensure continued functioning of the bladder/diaphragm system.

There are two predominant factors that will affect bladder/diaphragm life which should be taken into account when determining the need for and the frequency of bladder/diaphragm inspections:

1. Rubber subjected to prolonged exposure to water will eventually lose its elasticity properties due to water permeation. This will have an adverse effect on the ability of the bladder to expand and contract with changes in tank level.

2. Bladders/diaphragms subjected to repeated expansion and contraction will eventually fail (crack, rip and/or tear) due to fatigue-related failure of the material. This is more likely to occur in situations where a collapsing bladder undergoes a significant change in shape resulting in "pinching" or "kinking" of the surface. These points of surface geometry change will likely become bladder failure points.

Commensurate with the importance of chemistry control of the tank contents, a tank bladder/diaphragm program should be in place to inspect bladders/diaphragms on a routine basis to ensure their integrity. Tank/bladder vendor technical manuals should be consulted to assess proper inspection periodicity. These recommendations should be tempered with the specifics of the bladder/diaphragm application (e.g., mild versus harsh service conditions). A minimum inspection interval of ten years may be appropriate if there is no basis for any other frequency.

Recent experience at one host utility included two tank bladder/diaphragm failures. The failed bladders/diaphragms were subsequently eliminated in lieu of being replaced. One was replaced with a nitrogen cover gas system while the other was justified as no longer necessary. 
The following represents the more significant considerations when determining the best option for addressing replacement of a tank bladder:

Chemistry Control Evaluation-This evaluation should explore the specific design basis for the bladder and verify that the bladder's function is not really needed or can be adequately addressed with a nitrogen cover gas as a replacement.

Ease of Replacement-This evaluation should consider the potential difficulties in replacing a bladder with a new bladder or with a nitrogen cover gas system (or a tap into an existing nitrogen supply system). This would be a significant input into the evaluation of replacement costs and life cycle costs.

Replacement/Life Cycle Costs-This evaluation should itemize the cost of installing a nitrogen cover gas system (or a tap into an existing nitrogen supply system) and maintaining it over the life of the plant. These costs could be compared to the costs of replacement of the bladder with another bladder and continued periodic replacement/maintenance of the bladder over the life of the plant.

\subsubsection{Leak Location Test Methods for Tanks}

All of the tanks within the scope of this AMG contain liquids which, in the above-ground application, do not require sophisticated methods for detecting leakage (i.e., any significant liquid leakage generally can be traced to its source). In some applications, however, such as low pressure (0-15 psi) tanks with cover gas (e.g., nitrogen) tank leakage above the liquid level may present a challenge for leak detection and location efforts. Such challenges may require the use of the more aggressive detection and location methods discussed below.

Leak location tests have proven to be effective in above-ground storage tank (AST) systems. Leak location tests, however, do not determine the total leak rate for a system. Therefore, the leak test personnel cannot guarantee that all leaks within a system have been located. Some of these leak detection test methods include:

- Vacuum box bubble testing using soap solution, commercial leak detector solution, linseed oil, or other suitable solution.

- Vacuum box liquid penetrant testing.

- Vacuum box penetrant developer testing.

- Ammonia tracer gas with ammonia sensitive paint.

- Detector probe (sniffer) tracer testing using R12 or R22 halogen-rich tracer with a halogen diode leak detector.

- Detector probe (sniffer) tracer testing using SF6 halogen-rich tracer with an electron capture halogen leak detector.

- Detector probe (sniffer) tracer testing using helium with a helium mass spectrometer leak detector.

Considering the combination of test sensitivities, cost, necessary personnel training, and the ability to perform the test while an AST is being built or reconstructed, experience has shown the vacuum box bubble test method to be the best choice for leak location testing. Other 
leak location methods using penetrant materials or ammonia gas are good choices for specific situations or applications but have too many negatives to be used as the test method of first choice.[5.15] These methods are more technical in nature, require safety training and experience, and have considerable cost increases associated with an increase in test sensitivity.

To ensure that all leaks have been detected and repaired, owners of double-walled/bottom tanks have begun to use quantitative (volumetric) test methods. Testing of tanks for leaks is based on measuring parameters associated with volume change. These methods include:

- Pressure rise measurement:

Typically involves evacuating tank to pressure (vacuum) below atmospheric and holding for a duration without loss of vacuum.

- Pressure loss measurement:

Typically involves pressurizing a head of water in tank and holding for a duration without loss of pressure.

- Constant pressure mass flow measurement:

Uses liquid, typically water, to pressurize tank and monitor make up flow to maintain a constant pressure. Typically performed at pressure of a few pounds per square inch rather than a few inches of water.

USTs offer unique challenges to the ability to effectively detect leakage and to identify specific locations of leakage. They are typically monitored for inadvertent releases by one of the following industry-practice methods[5.2]:

- Automatic in-tank gauging:

Monitors are permanently installed in tank and linked electronically to nearby control devices. Calculates a change in volume.

- Vapor monitoring:

Senses and measures "fumes" in the soil around the tank. Performed manually or automatically.

- Interstitial monitoring:

Measures parameters of void between walls in double-wall tanks by a variety of methods. Methods vary from simple dip stick to continuous vapor monitoring.

- Other methods:

Typically leak effects monitoring using groundwater sampling, observation wells, or buried detection systems.

\subsection{Programs/Techniques Applied to Tanks/Pools}

This section evaluates the effectiveness of the various programs/techniques described in Sections 5.2 and 5.3 with respect to their capability to prevent or detect and mitigate the significant aging mechanisms identified in Section 4. The evaluation of programs/techniques continues with the grouped approach presented in Section 3. Specifically, Section 3.2.3 divided the tank/pools into five different categories:

- tanks containing clean water

- tanks containing diesel fuel oil 
- tanks containing chemicals

- tanks containing dirty/raw/waste fluid

- pools (spent fuel pool)

Due to the unique characteristics of the tanks within the scope of the AMG as compared to the pools within the scope of the AMG, tanks will be treated separately from pools in the management programs discussions that follow.

\subsubsection{Tank Aging Management Programs}

Table 4-7 listed the results of a tank and pool aging analysis based on input data provided by the host utilities. The following sections summarize effective program/technique evaluations for each associated aging mechanism.

The results of the Section 4 aging analysis can be reduced to a simplified form. Table 5-1 illustrates the two basic material types evaluated and a summary of the aging mechanisms found to be of concern for the selected tank fluid contents. The result is six specific subgroups of tanks that will have aging effects management programs defined.

Table 5-1 indicates that aging concerns exist for stainless steel tanks that contain raw water. This combination is conducive to the existence of several aging mechanisms: TGSCC, IGSCC, crevice pitting corrosion, and MIC. All other aging mechanisms may be considered non-significant for stainless steel tanks.

The most common aging mechanism for carbon steel tanks is general corrosion. Experience has shown that general corrosion of carbon steel is a concern regardless of fluid type. Other potentially significant aging mechanisms for carbon steel tank components are crevice pitting corrosion, selective leaching, galvanic corrosion, MIC, erosion/corrosion, twophase erosion, and intergranular attack.

Figure 5-1 describes a method for determining appropriate aging management practices. The process illustrated by Figure 5-1 begins with consideration of a tank/pool's intended function (i.e., its basis for selection in the scope of this AMG). This is supported by the aging effects analysis for a given tank/pool presented in Section 4. Activities or potential program elements currently in effect under the plant's current licensing basis can then be identified. These program elements are then reviewed in light of the aging management requirements so that their adequacy can be determined. Where the existing program elements provide the requisite aging management, no additional actions need to be taken. If the program elements do not provide the requisite aging management, it may be necessary to alter the program elements or develop one or more new program elements. 


\section{AGING MANAGEMENT GUIDELINE FOR TANKS AND POOLS}

\begin{tabular}{|c|c|c|c|c|c|c|c|c|c|c|c|c|c|}
\hline Material & $\begin{array}{l}\text { Fluid } \\
\text { Type }\end{array}$ & $\begin{array}{c}\text { General } \\
\text { Corrosion }\end{array}$ & $\begin{array}{l}\text { Selective } \\
\text { Leaching }\end{array}$ & $\begin{array}{l}\text { Crevice } \\
\text { Pitting } \\
\text { Corrosion }\end{array}$ & $\begin{array}{l}\text { Galvanic } \\
\text { Corrosion }\end{array}$ & MIC & $\begin{array}{l}\text { IG } \\
\text { SCC }\end{array}$ & $\begin{array}{l}\text { TG } \\
\text { SCC }\end{array}$ & $\begin{array}{c}\text { Erosion } \\
\text { Corrosion }\end{array}$ & $\begin{array}{l}\text { Two- } \\
\text { Phase } \\
\text { Erosion }\end{array}$ & IGA & $\begin{array}{l}\text { Hydrogen } \\
\text { Damage } \\
\text { (Note 2) }\end{array}$ & $\begin{array}{c}\text { Issue } \\
\text { Summary }\end{array}$ \\
\hline Austenitic SS & $\begin{array}{l}\text { Raw } \\
\text { Water }\end{array}$ & 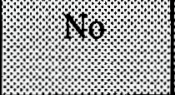 & No: & Yes & 106. & Yes & Yes & Yes & $11 \%$ & $4 \%$ & 10: & $1 \%$ & Yes \\
\hline \multirow[t]{5}{*}{ Carbon Steel } & Air & Yes & Nio: & \%18. & $1 \%$ & No: & $10 \%$ & $10 \%$ & $10 \%$ & 180 & ror & r.: & Yes \\
\hline & $\begin{array}{l}\text { Fuel } \\
\text { Oil }\end{array}$ & Yes & Nio. & Yes & 18 & Yes & 110. & No. & $4 \%$ & $1 \%$ & No. & 110 & Yes \\
\hline & $\begin{array}{l}\text { Clean } \\
\text { Water }\end{array}$ & Yes & No. & Yes & $10 \%$ & No. & $10 \%$ & 10. & $10 \%$ & $1 \%$ & Ni?. & 110. & Yes \\
\hline & $\begin{array}{l}\text { Raw } \\
\text { Water }\end{array}$ & Yes & No: & Yes & 10\% & Yes & 10 & 10 & 110 & \%i: & 1ro. & 1\% & Yes \\
\hline & $\begin{array}{l}\text { Wet } \\
\text { Steam }\end{array}$ & Yes & 10 & 18 & 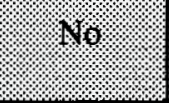 & 10 & 10 & \%). & $10 \%$ & Yes & No. & 10 & Yes \\
\hline $\begin{array}{l}\text { Reinforced } \\
\text { Concrete } \\
\text { (Pools only) }\end{array}$ & $\begin{array}{l}\text { Borated } \\
\text { Water }\end{array}$ & \begin{tabular}{|l} 
Yes \\
See Note \\
1
\end{tabular} & 110 & $40 \%$ & 118. & No. & $10 \%$ & 110. & $10 \%$ & $10 \%$ & 18 & 10. & Yes \\
\hline \multicolumn{14}{|c|}{$\begin{array}{l}\text { Note 1: Based on structural aging mechanisms associated with aggressive chemical attack and corrosion of embedments. } \\
\text { Note 2: Hydrogen damage is only a concern for carbon steel, when cathodic protection is used, and when the voltage potential is incorrectly } \\
\text { set. }\end{array}$} \\
\hline
\end{tabular}




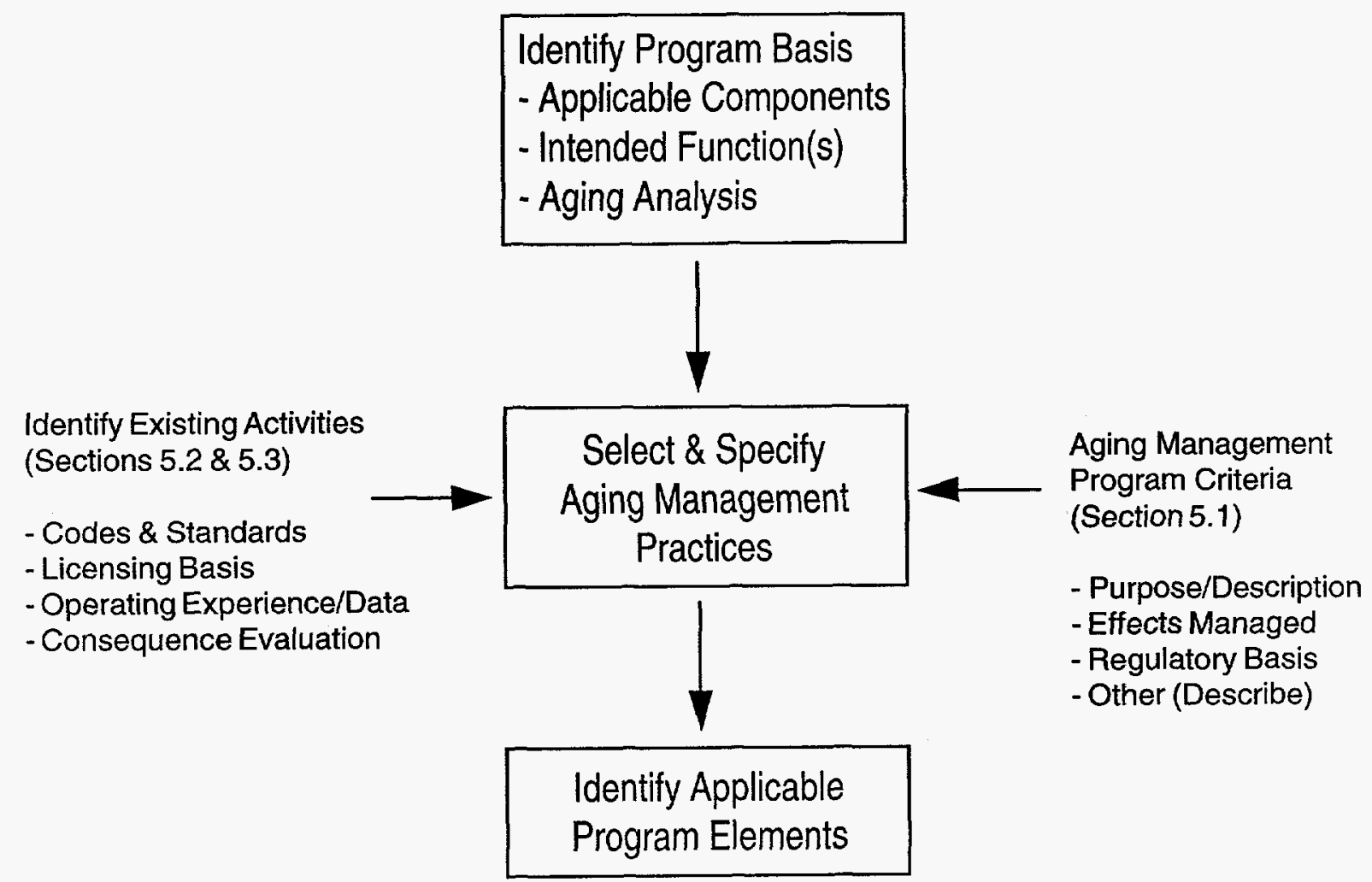

Potential Aging Management Program Elements:

- Inservice Inspection Program (ASME Section XI) (5.2.1)

- Preventive Maintenance Program (5.2.2)

- Microbiologically Influenced Corrosion (MIC) Control Program (5.2.3)

- Other Licensing Basis Programs (5.2.4)

- Quality Assurance (10 CFR 50.34) (5.2.4.1)

- Technical Specifications (10 CFR 50.36) (5.2.4.2)

- Maintenance Rule (10 CFR 50.65) (5.2.4.3)

- Plant Problem Notification (10 CFR 50.72 \& 73) (5.2.4.4)

- Feedback of Operating Experience (TMI Action Item I.C.5) (5.2.4.5)

- Boric Acid Corrosion of Carbon Steel (GL 88-05) (5.2.4.6)

- Raw Water (GL 89-13) (5.2.4.7)

- Diesel Fuel Oil Tank (RG 1.137) (5.2.4.8)

- Spent Fuel Pool (Bulletin 94-01) (5.2.4.9)

- Plant-Specific Regulatory Commitments (FSAR, SER, Other) (5.2.4.10)

- Operator Activities (5.2.5)

- Protective Coatings Program (5.2.6)

- Lay-up Programs (5.3.1)

- Control of External Corrosion on Underground Systems (NACE RP-01-69) (5.3.2)

- Tank Bladder/Diaphragm Programs (5.3.3)

- Leak Location Testing Programs (5.3.4)

Figure 5-1. Determination of Aging Management Practices. 
Figure 5-2 presents the potential program elements from Figure 5-1 in a different format. The pyramid shape illustrates the hierarchical relationship between the potential program elements. The bottom tier, representing Regulatory Oversight program elements, provides a general foundation to support the more specific preventive and mitigative elements above. These elements are generally required of all nuclear utilities to ensure effective aging management.

The second tier of Figure 5-2 represents program elements that could be used to prevent significant degradation of tank components. The third and final tier represents those program elements that could be used to mitigate the effects of degradation of tank components. These program elements detect the presence of degraded tank conditions mostly through inspections (exterior and/or interior). Once detected, appropriate corrective actions will be assured by Regulatory Oversight program elements.

Because the Regulatory Oversight program elements are common to all tanks at all nuclear utilities, they will not be discussed further for the six specific tank subgroups identified in Table 5-2.

Table 5-2 illustrates specific program elements that provide a basis for successful management for the six tank subgroups. Table 5-2 is divided into two distinct halves. The first half provides a quick reference to the material/fluid combination that would be encountered at a power plant and the associated aging mechanisms and aging effects. This half provides the basis for selecting aging management program elements. The second half shows the programs that can be used to manage the aging effects. The two distinct halves of Table 5-2 are discussed below.

Aging Effects (Program Bases)

Each tank system has applicable aging mechanisms and the potential effects of the aging mechanism identified. Generally, aging effects for tanks can be summarized as either cracking, loss of material or change in material properties. The column identified as "Likelihood of occurrence" is based on industry experience. There are two levels of consideration, either High $(\mathrm{H})$ or Low $(\mathrm{L})$. High is used to indicate that the incidence of the aging mechanism has occurred often and is likely to occur if no preventive actions are initiated and maintained. Low indicates that the occurrence is rare.

The consequences of the effects of aging are qualified by being either High or Low. Consequences are a result of actions taken at the first indication of the aging effect (i.e., if prompt actions are taken to mitigate the aging effect, the consequence will be as given in the table (all Low)).

The typical first indication of aging effects is visual: either a leak is observed or a change in level is indicated where none should exist. The results are usually a release of fluid to the environment. Aged tanks do not exhibit catastrophic failures without prior indications of seepage/leakage. 

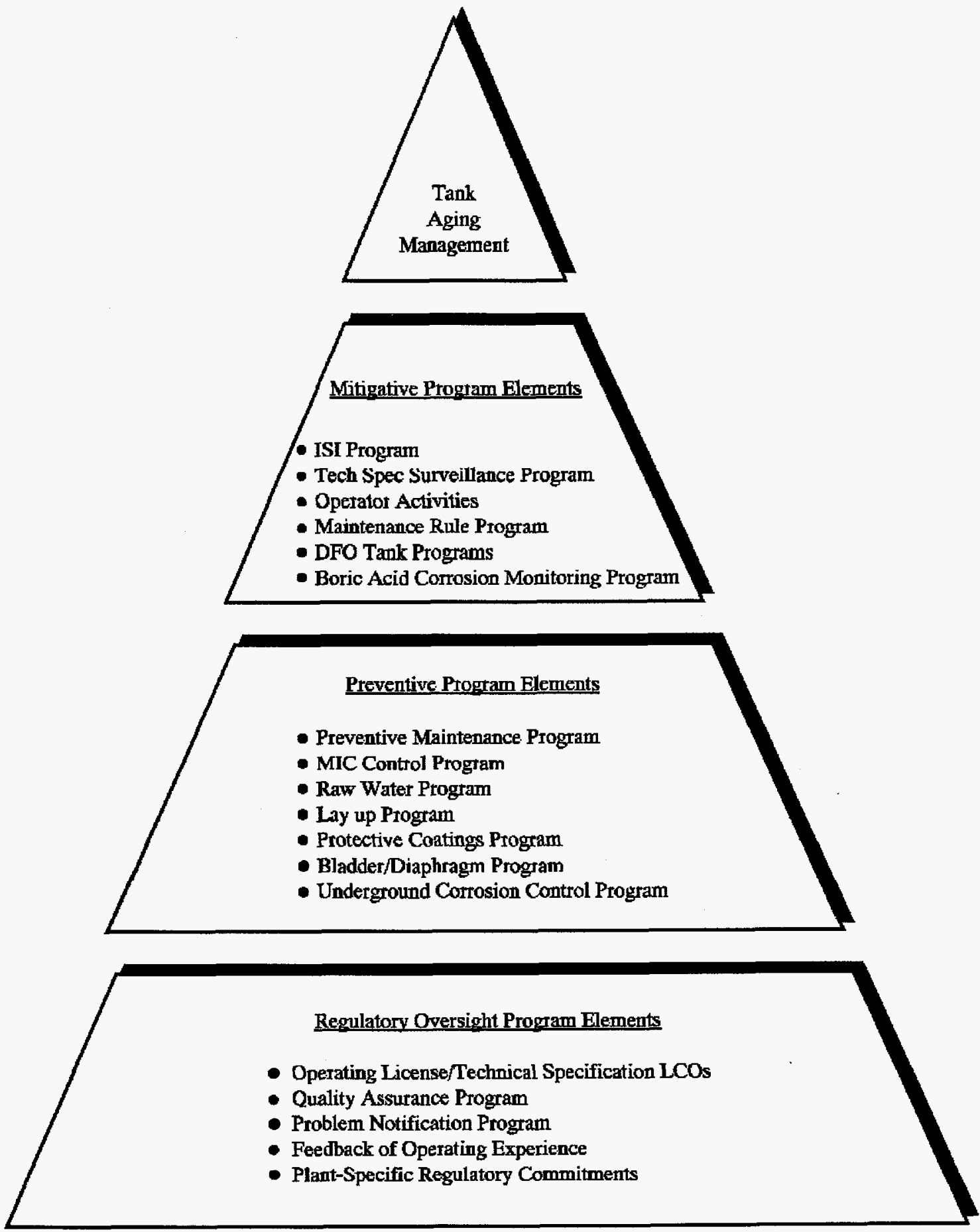

Figure 5-2. Tank Aging Management Program Element Hierarchy. 
AGING MANAGEMENT GUIDELINE FOR TANKS AND POOLS

Table 5-2. Tank Aging Effects and Aging Management Program Evaluation

\begin{tabular}{|c|c|c|c|c|c|c|}
\hline $\begin{array}{c}\text { Tank System } \\
\text { (Material / Fluid) }\end{array}$ & $\begin{array}{l}\text { Aging } \\
\text { Mechanism }\end{array}$ & $\begin{array}{l}\text { Aging } \\
\text { Effect }\end{array}$ & $\begin{array}{l}\text { Likelihood } \\
\text { of } \\
\text { occurrence }\end{array}$ & $\begin{array}{c}\text { Consequence if } \\
\text { prompt actions } \\
\text { are taken }\end{array}$ & $\begin{array}{l}\text { Preventive } \\
\text { Programs }\end{array}$ & $\begin{array}{l}\text { Mitigative } \\
\text { Programs }\end{array}$ \\
\hline $\begin{array}{l}\text { Stainless Steel/ } \\
\text { Raw Water }\end{array}$ & $\begin{array}{c}\text { TGSCC } \\
\text { IGSCC } \\
\text { Crevice Pitting } \\
\text { MIC }\end{array}$ & $\begin{array}{l}\text { Pitting } \\
\text { Cracking }\end{array}$ & $\mathrm{H}^{1}$ & $\mathrm{~L}^{2}$ & $\begin{array}{l}\text { Preventive Maintenance program } \\
\text { Raw Water Program } \\
\text { MIC Control Program }\end{array}$ & $\begin{array}{l}\text { ISI Program } \\
\text { Maintenance Rule Program } \\
\text { Operator Activities }\end{array}$ \\
\hline $\begin{array}{c}\text { Carbon Steel/ } \\
\text { Air }\end{array}$ & Corrosion & Wall Thinning & L & L & $\begin{array}{l}\text { Preventive Maintenance Program } \\
\text { Coating Surveillance Program }\end{array}$ & $\begin{array}{l}\text { ISI Program } \\
\text { Maintenance Rule Program } \\
\text { Operator Activities } \\
\end{array}$ \\
\hline $\begin{array}{l}\text { Carbon Steel/ } \\
\text { Fuel Oil }\end{array}$ & $\begin{array}{l}\text { Corrosion } \\
\text { Crevice Pitting } \\
\text { MIC }\end{array}$ & $\begin{array}{l}\text { Wall thinning } \\
\text { Pitting } \\
\text { Cracks }\end{array}$ & $\mathrm{H}$ & $\mathrm{L}$ & $\begin{array}{l}\text { Preventive Maintenance Program } \\
\text { MIC Control Program . } \\
\text { Coating Surveillance Program }\end{array}$ & $\begin{array}{l}\text { ISI Program } \\
\text { Maintenance Rule Program } \\
\text { Operator Activities } \\
\text { Fuel Oil Tank Program } \\
\text { Underground Storage Tank Program } \\
\text { Technical Specification Surveillance Program }\end{array}$ \\
\hline $\begin{array}{l}\text { Carbon Steel/ } \\
\text { Clean Water }\end{array}$ & $\begin{array}{c}\text { Corrosion } \\
\text { Crevice Pitting }\end{array}$ & $\begin{array}{l}\text { Wall thinning } \\
\text { Pitting } \\
\text { Cracks }\end{array}$ & $\mathrm{H}$ & $\mathrm{L}$ & $\begin{array}{l}\text { Preventive Maintenance Program } \\
\text { Coating Surveillance Program }\end{array}$ & $\begin{array}{l}\text { ISI Program } \\
\text { Maintenance Rule Program } \\
\text { Operator Activities } \\
\text { Technical Specification Surveillance } \\
\text { Program }\end{array}$ \\
\hline $\begin{array}{l}\text { Carbon Steel/ } \\
\text { Raw Water }\end{array}$ & $\begin{array}{l}\text { Corrosion } \\
\text { Crevice Pitting } \\
\text { MIC }\end{array}$ & $\begin{array}{l}\text { Wall thinning } \\
\text { Pitting } \\
\text { Cracks }\end{array}$ & $\mathrm{H}$ & $\mathrm{L}$ & $\begin{array}{l}\text { Preventive Maintenance Program } \\
\text { Raw Water Program } \\
\text { MIC Control Program } \\
\text { Coating Surveillance Program }\end{array}$ & $\begin{array}{l}\text { ISI Program } \\
\text { Maintenance Rule Program } \\
\text { Operator Activities }\end{array}$ \\
\hline $\begin{array}{l}\text { Carbon Steel/ } \\
\text { Wet Steam }\end{array}$ & $\begin{array}{c}\text { Corrosion } \\
\text { Two-Phase erosion }\end{array}$ & Wall thinning & $\mathrm{H}$ & L & $\begin{array}{l}\text { Preventive Maintenance Program } \\
\text { Flow Assisted Corrosion (FAC) } \\
\text { Program }\end{array}$ & $\begin{array}{l}\text { ISI Program } \\
\text { Maintenance Rule Program } \\
\text { Operator Activities }\end{array}$ \\
\hline
\end{tabular}

\footnotetext{
${ }^{1} \mathrm{H}=$ high

${ }^{2} \mathrm{~L}=10 \mathrm{w}$
} 
Aging Management Programs

Aging management programs can be divided into two groups, preventive and mitigative. The preventive programs are those programs that are designed to prevent the occurrence of a particular phenomenon or aging mechanism. Mitigative programs are those that are used to identify and monitor or correct an undesirable phenomenon or situation.

Each program plan should be tailored to plant-specific needs and requirements. The fine details of the program and the specific steps should be developed to assure that the aging management requirements are met. An example of a starting point for the development of a basic plan for a tank system is shown in Table 5-3. Typical frequencies to consider when developing or modifying tank or pool aging management programs are noted in Table 5-4. Typical frequencies for tanks or pools aging management programs are based on routine, periodic and one-time evaluation considerations. The intent of a one-time evaluation is to identify tank/pool aging management activities (if any) required and inspection frequencies based on component-specific analysis and focused one-time inspections. Typical elements to consider when performing a one-time evaluation for tanks or pools include:

- Materials of construction and fluid environment

- Interfacing system attachments and foundations

- Margin evaluation

- Experience-based evaluation (industry- and plant-specific)

- Coating lifetime evaluation

- Liner lifetime evaluation

- Cathodic protection (sacrificial anode)

\subsubsection{Pool Aging Management Programs}

Potential aging mechanisms for pools are:

- corrosion/corrosion-related cracking,

- steel embedment/rebar corrosion,

- aggressive chemical attack, and

- liner damage from wear or impact.

\subsubsection{Liner Corrosion}

Stress corrosion cracking and crevice corrosion are two common types of liner aging. The occurrence of crevice corrosion and SCC in stainless steel liners is gaining more attention as nuclear power plants age. Crevice corrosion may occur in the form of local acid or impurity attack at existing notches or from the influences of microbiological activity. Key locations include along seam weld joints, the lower 6 inches of vertical liner, and the pool bottom liner plate. SCC would most likely occur at seam weld locations, especially those in Type 304 stainless steel that were not heat-treated. The causes of SCC include the combination of tensile stresses (residual plus pool-related), sensitized stainless steel, and slightly acidic water. Because the low-temperature pool water is typically not aggressive to stainless steel, any SCC 
Table 5-3. Framework for Basic Tank System Aging Management Program

Preventive Program (For Corrosion Protection)

$\rightarrow$ Cathodic Protection, or

$\rightarrow$ Interior lining with regular inspection

or

$\rightarrow$ Both

\section{Mitigative Program}

$\rightarrow$ Operational monitoring, either

- Gauging (automatic or manual), or

- Monitoring gaps/tight spaces, or

- Vapor monitoring

or

$\rightarrow$ Inventory Control and tank tightness testing

or

$\rightarrow$ Both

Environmental Concerns (Spill and overflow devices) 
AGING MANAGEMENT GUIDELINE FOR TANKS AND POOLS

\begin{tabular}{|c|c|c|c|}
\hline Frequency & Activity & Typical Frequency & Remarks \\
\hline \multirow[t]{2}{*}{ Routine } & $\begin{array}{l}\text { Operational monitoring } \\
\text { - visual leakage checks } \\
\text { - gauging (automatic or manual) } \\
\text { - vapor/interstitial monitoring }\end{array}$ & Continuous to weekly & $\begin{array}{l}\text { Safety Class } 2 \text { or } 3 \text { tanks typically have technical specification surveillance requirements to } \\
\text { verify fluid level/boundary integrity. }\end{array}$ \\
\hline & $\begin{array}{l}\text { Cathodic Protection } \\
\text { (impressed current readings) }\end{array}$ & Daily to monthly & Trending and analysis of impressed current readings for changes. \\
\hline \multirow[t]{2}{*}{ Periodic } & Tank tightness & 10 year & $\begin{array}{l}\text { - 10-year visual exam and pressure test per ASME Boiler and Pressure Vessel Code - } \\
\text { Section XI (for Safety Class } 2 \text { or } 3 \text { tanks) } \\
-2 \text { to } 10 \text { year for selected UST (e.g., fuel oil) based on State environmental requirements }\end{array}$ \\
\hline & Coating/liner/surface inspection & $5-10$ year & For coatings use practical coating lifetime (based on 5 to $10 \%$ breakdown of top coat). \\
\hline \multirow[t]{7}{*}{$\begin{array}{l}\text { One-Time } \\
\text { Evaluations }\end{array}$} & $\begin{array}{l}\text { Materials of construction and fluid } \\
\text { environment }\end{array}$ & Note 1 & $\begin{array}{l}\text { Perform focused one-time inspection based on plausible degradation and associated aging } \\
\text { effects. Take corrective actions based on one-time inspection/analysis. }\end{array}$ \\
\hline & $\begin{array}{l}\text { Interfacing systems, attachments, and } \\
\text { foundations }\end{array}$ & Note 1 & $\begin{array}{l}\text { Perform focused one-time inspection based on plausible degradation and associated aging } \\
\text { effects. Take corrective actions based on one-time inspection/analysis. }\end{array}$ \\
\hline & Margin Evaluation & Note 1 & $\begin{array}{l}\text { Prediction of operational lifetime based on evaluation of degration rate (e.g., corrosion), } \\
\text { materials of construction, and fluid environment. }\end{array}$ \\
\hline & $\begin{array}{l}\text { Experience-based evaluation } \\
\text { (Industry- and plant-specific) }\end{array}$ & Note 1 & Focused inspection/analysis in response to documented industry tank/pool failures. \\
\hline & Coating Lifetime Evaluation & Note 1 & $\begin{array}{l}\text { Determine practical coating lifetime (based on } 5 \text { to } 10 \% \text { breakdown of top coat) or periodic } \\
\text { inspection requirements. }\end{array}$ \\
\hline & Liner lifetime evaluation & Note 1 & Determine liner lifetime or periodic inspection requirements. \\
\hline & $\begin{array}{l}\text { Cathodic protection } \\
\text { (sacrificial anode) }\end{array}$ & Note 1 & Review tank operational history and original sizing analysis. \\
\hline
\end{tabular}


initiation/propagation would likely be at slow rates. Removal of existing material sensitization and residual stresses via inplace heat treatment is not considered cost-effective.

Current SCC detection practices in thin wall (less than $9.5 \mathrm{~mm}$ [0.375 in] thick) stainless steel, especially at early stages, are not accurate or timely. Therefore, the pool leakage monitoring system is of prime importance to an aging management program. If leakage is detected and generally located by this system, enhanced NDE (ultrasonics, liquid penetrant, etc.) may be used to further pinpoint the source.

An additional concern results from the addition of high density storage racks into a fuel pool. The close spacings between racks results in lower flow conditions (stagnation), greater contamination concentrations, and a more attractive environment for MIC. High-density racks also further decrease available access space to the pool bottom liner for inspections, vacuuming, and repair.[5.20]

\subsubsection{Steel Embedment/Rebar Corrosion}

Addition of boron to the cooling water in spent fuel pools not only improves radiation mitigation but also creates a relatively corrosive fluid for exposed carbon steel. Carbon steel is typically used for attaching the stainless steel liner to the pool concrete structure and within the concrete walls and slabs as reinforcing steel. Corrosion rates of greater than 50 mils per year have been reported for carbon steel exposed to boric acid at low temperatures and concentrations. As such, it is important to protect existing carbon steel components from this exposure.

Primary concerns for exposure exist at the fuel pool/refueling floor interface and at leak detection collection port locations. In the former location, pool water may be splashed onto the concrete floor, creating an avenue for periodic embedded steel or rebar exposure. Should coatings on the exposed concrete or embedded steel be degraded, corrosion cell development and propagation may begin. Within leak detection collection boxes, pool water leakage in large volumes may cause the concrete boundary and embedded steel to be saturated. Sampling/testing of fluids obtained from the leak detection system may identify the presence of any ongoing corrosion activity (i.e., $\mathrm{Fe}_{2} \mathrm{O}_{3}$ (iron oxide) or rust particles).

To prevent enhanced corrosion from occurring, aging management must consider two programs: (1) maintenance of protective coatings on exposed concrete and embedded steel surfaces and (2) periodic flushing/cleanout of leak detection collection boxes. The protective coatings on the refueling floor and exposed embedments should be periodically inspected and refurbished at regular intervals.

Periodic flushing and cleanout of leak detection collection boxes and piping will provide some assurance of proper function. In addition, this will clear any blockages, prevent the accumulation of aggressive fluids in the system, and allow proper drying. [5.20] 


\subsubsection{Concrete Degradation}

Concrete degradation due to aggressive chemical attack by borated water is plausible. Borated water is somewhat aggressive to concrete over long exposure periods. Concrete exposed to weak acids $(\mathrm{pH}>5.5)$ may spall, be eroded, or locally crack. Under slightly acidic exposures, these effects are generally long term and require sufficient concentration levels for widespread damage. Typically, both the refueling floor and fuel pool concrete were provided with a durable protective coating to resist acid exposure effects. If durable, this coating will protect the subsurface or embedded reinforcing steel. Epoxy injection of existing cracks in the refueling floor is recommended to reduce the influx of borated water. Maintenance of any epoxy/coating systems will effectively mitigate this effect.[5.20] Table 5-5 presents a pool aging effects and aging management program evaluation.

\subsubsection{Aging Management Program Effectiveness Determination}

Section 3.4 described operating and service history obtained from several sources of data. Fortunately, few failures were reported, which indicates an overall satisfactory record of tank/pool maintenance. Due to the sparsity of the data, a quantitative evaluation of the effectiveness of the aging management programs recommended in Tables 5-2, 5-4, and 5-5 is not possible. However, since there were so few failures, one can qualitatively say that existing programs are effective. 
AGING MANAGEMENT GUIDELINE FOR TANKS AND POOLS

\begin{tabular}{|c|c|c|c|c|c|c|}
\hline Pool Aging Discussion & Aging Mechanism & $\begin{array}{l}\text { Aging } \\
\text { Effect }\end{array}$ & $\begin{array}{l}\text { Likelihood of } \\
\text { occurrence }\end{array}$ & $\begin{array}{l}\text { Consequence } \\
\text { if prompt } \\
\text { actions are } \\
\text { taken }\end{array}$ & Preventive Program & Mitigative Programs \\
\hline Liner Corrosion & $\begin{array}{l}\text { Stress Corrosion Cracking } \\
\text { Crevice Pitting } \\
\text { MIC }\end{array}$ & $\begin{array}{l}\text { Cracking } \\
\text { Pitting }\end{array}$ & High & High & $\begin{array}{l}\text { Pool Leakage Monitoring } \\
\text { Program } \\
\text { Liner Inspection Program }\end{array}$ & $\begin{array}{l}\text { Leak Detection } \\
\text { Verification } \\
\text { Operator Activities }\end{array}$ \\
\hline $\begin{array}{l}\text { Steel Embedment/Rebar } \\
\text { Corrosion } \\
\text { (Note 1) }\end{array}$ & Corrosion & Corrosion & High & High & $\begin{array}{l}\text { Periodic Flushing of Leak } \\
\text { Detection Box } \\
\text { Coatings Surveillance Program }\end{array}$ & $\begin{array}{l}\text { Leak Detection } \\
\text { Verification } \\
\text { Operator Activities }\end{array}$ \\
\hline $\begin{array}{l}\text { Concrete Degradation } \\
\text { (Note 1) }\end{array}$ & $\begin{array}{l}\text { Aggressive Chemical } \\
\text { Attack }\end{array}$ & $\begin{array}{l}\text { Spalling } \\
\text { Erosion } \\
\text { Cracking }\end{array}$ & High & High & $\begin{array}{l}\text { Epoxy Injection of Cracks } \\
\text { Coatings Surveillance Program }\end{array}$ & $\begin{array}{l}\text { Leak Detection } \\
\text { Verification } \\
\text { Operator Activities }\end{array}$ \\
\hline \multicolumn{7}{|c|}{$\begin{array}{l}\text { Note 1: Steel embedment/rebar corrosion and concrete degradation occur primarily as a result of pool liner failure. Steel embedment/rebar corrosion and concrete } \\
\text { degradation are typically characterized as structural aging concerns, but have been presented for completeness. An aging degradation assessment and } \\
\text { aging management program evaluation of Class I structures such as the refueling canal and fuel storage facility can be found in EPRI TR-103842, "Class } \\
\text { I Structures License Renewal Industry Report, " Revision 1, dated July 1994.[5.21] }\end{array}$} \\
\hline
\end{tabular}




\subsection{References}

5.1 Title 10, U.S. Code of Federal Regulations, 10 CFR Part 54, "Requirements for Renewal of Operating Licenses for Nuclear Power Plants," May 8, 1995.

5.2 American Society of Mechanical Engineers (ASME) Boiler and Pressure Vessel Code, Section XI, "Rules for Inservice Inspection of Nuclear Power Plant Components," 1989 with 1994 addenda.

5.3 American Society of Mechanical Engineers Boiler and Pressure Vessel Code, Code Case N-498-1, "Alternative Rules for 10 Year System Hydrostatic Testing for Class 1, 2 and 3 Systems, Section XI," May 11, 1994.

5.4 Title 10, U.S. Code of Federal Regulations, Part 50, "Domestic Licensing of Production and Utilization Facilities," 1989 with 1994 addenda.

5.5 "Aging Management Guideline for Commercial Nuclear Power Plants - Heat Exchangers, " Sandia National Labs Contractor Report SAND93-7070, June 1994.

5.6 Service Bulletin No. 279, "BIOBOR JF Fuel Fungicide Service Information for General Use," United States Borax \& Chemical Corporation, 1981.

5.7 "Clarification of TMI Action Plan Requirements," NUREG-0737, November 1980.

5.8 NRC Generic Letter 88-05, "Boric Acid Corrosion of Carbon Steel Reactor Pressure Boundary Components in PWR Plants," March 17, 1988.

5.9 "Boric Acid Corrosion of Carbon Steel and Low-Alloy Steel Pressure Boundary Components," EPRI Report No. NP-5985, 1988.

5.10 NRC Generic Letter 89-13, "Service Water System Problems Affecting SafetyRelated Equipment," July 18, 1989.

5.11 NRC Generic Letter 89-13, Supplement 1, "Service Water System Problems Affecting Safety-Related Equipment," April 4, 1990.

5.12 U.S. NRC Regulatory Guide 1.137, "Fuel-Oil Systems for Standby Diesel Generators," Revision 1, October 1979.

5.13 NRC Bulletin 94-01, "Potential Fuel Pool Draindown Caused by Inadequate Maintenance Practices at Dresden Unit 1," April 14, 1994.

5.14 Title 10, U.S. Code of Federal Regulations, Part 20, "Standards for Protection Against Radiation," 1988.

5.15 Sherlock, C. N., "A Catch-22: Leak Testing of Aboveground Storage Tanks with Double Bottoms," Materials Evaluation, July 1994. 
5.16 Eng, J. T., "Preventing Corrosion with Coatings," Chemical Processing, February 1995.

5.17 Brevoort, "The Coatings Consumer: Understanding Initial and Long-Term Painting Costs, " Plant Services, April 1994.

5.18 American Society for Testing and Materials, ASTM Standard D610, "Standard Test Method for Evaluating Degree of Rusting on Painted Steel Surfaces, " 1989 Revision.

5.19 "Control of External Corrosion on Underground or Submerged Metallic Piping Systems," National Association of Corrosion Engineers, NACE Standard RP-0169 (1976 Revision).

5.20 Hookham, C. J., "Aging Management of Nuclear Fuel Pool Structures," Proceedings of the American Power Conference, May 1991, pp. 504-508.

5.21 EPRI Report TR-103942, "Class I Structures License Renewal Industry Report," Revision 1, July 1994. 



\section{OTHER AGING MANAGEMENT CONSIDERATIONS}

It has been shown in Section 3.4 that relatively few tank or pool failures were reported in the LER and NPRDS databases. The NPRDS database was searched from December 1976 through September 1993 and only 11 age-related failures were reported. Similarly, the entire LER database was searched up to December 1993 and only 8 age-related failures were reported. Similarly, from the LER database only two age-related failures were reported for pools. Overall, this indicates that there have been few reported tank/pool age-related failures over the approximately 20 -year span of the data. Therefore, one can say that, overall, tank/pool aging programs are effective in managing the aging of tank/pool components. As a result, there are no additional recommendations made in this AMG to enhance existing programs.

There was interest in including an overall discussion related to cathodic protection systems. That discussion follows in Section 6.1. Other aging management considerations are provided on the following topics:

Section 6.2: Environmental Considerations

Section 6.3: Use of Composite Tanks

Section 6.4: Pulsed Infrared Imaging Inspection of Above-Ground Storage Tanks (ASTs)

\subsection{Cathodic Protection (Corrosion Prevention)}

Cathodic Protection is a corrosion control technique (used on both below-ground and above-ground components) to prevent the corrosion of a metal surface by making that surface the cathode of an electrochemical cell.

Two prevalent design approaches are used for protection: "impressed current" and "galvanic (sacrificial) anodes."

Typically, the impressed current method provides corrosion protection to components requiring high current levels, and when a power source is available. The anodes are nonsacrificial; negligible mass is lost because of the externally induced current.

The galvanic anode method is preferred when current requirements are low, and/or the protected component is remote from available power sources. Sacrificial anodes are used as the current source whereby anode mass is depleted during the protective process. Typical protective time frames range from 5 to 20 years, depending upon installation/environmental conditions.[6.1]

\subsubsection{Impressed Current Systems}

The impressed current method uses direct current supplied by a device employing a power source external to the electrode system-see Figure 6-1.[6.2] Typical anode materials are graphite, steel, and cast iron with chromium. These designs are typically preferred if high current demand is required for anticipated extended life requirements. 


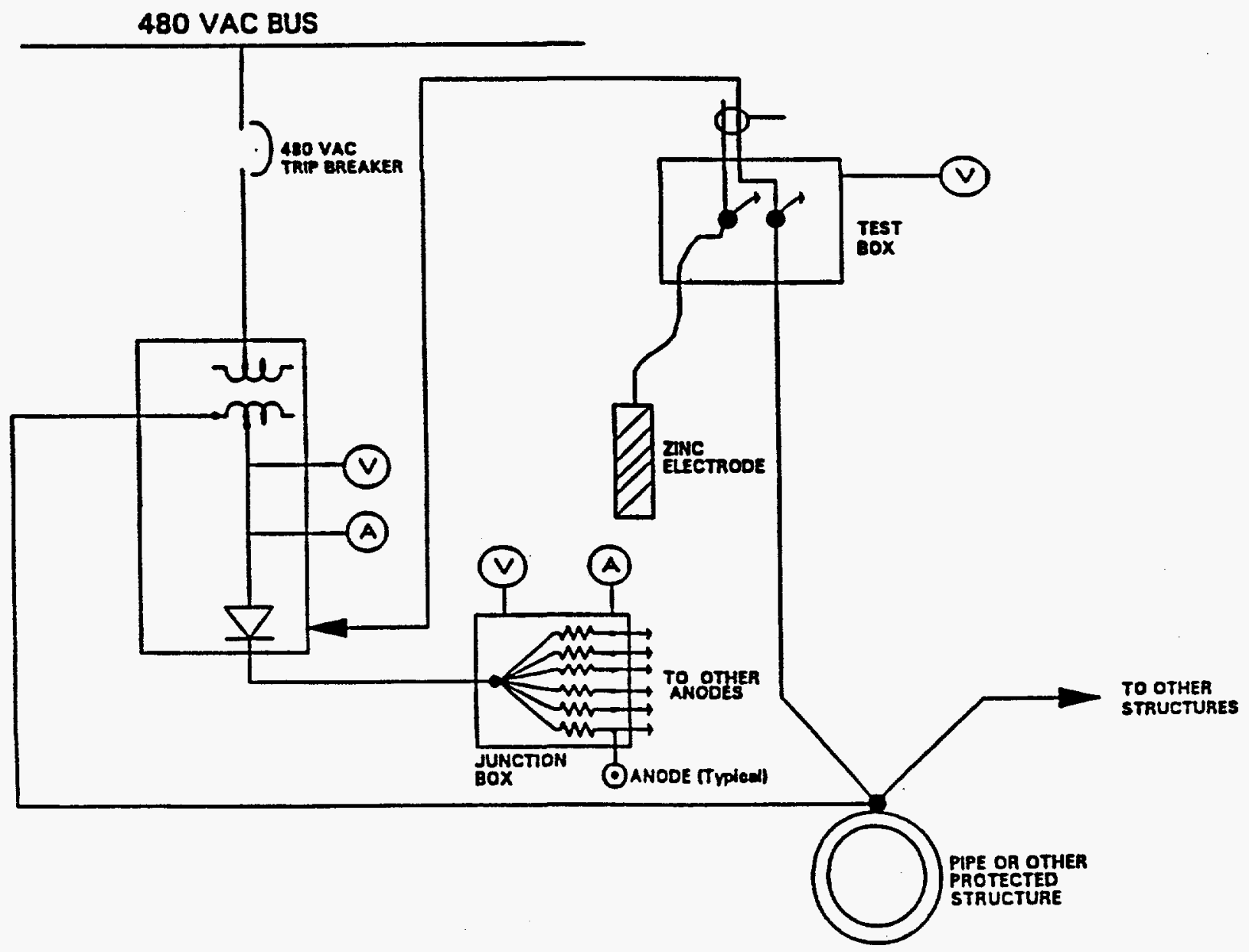

Figure 6-1. Typical Impressed Current Cathodic Protection System Schematic Diagram (nonautomatic). 
Cathodic protection is most effective when combined with other methods of corrosion control (usually with treating/coating metallic surfaces). Impressed current cathodic protection serves as a dynamic and adjustable means of securing the metal against corrosion loss, which would otherwise occur at coating flaws or surfaces not effectively reached by inhibitors. Automatic potential rectifier systems decrease the likelihood of underprotection or the excessive use of power and coat disbanding (blistering) due to overprotection with overcurrent.

The protective current requirements for corrosion control constantly vary in accordance with location and time. Uniform protection over a protected metallic object is rarely achieved or required. Active systems control can be advantageous because the object may have locations historically susceptible to corrosion. The protection could be concentrated at these locations. The disadvantage is that this active system requires frequent monitoring and adjustment for optimum and consistent corrosion protection.

Monitoring and adjustment can be conducted automatically with potential control systems (see Figure 6-2). These systems constantly monitor the desired potential between the reference cell (usually a copper-sulfate electrode located near the subject structure) and the cathode, and are balanced against a pre-set potential. Any differences result in a modification of the applied current.

For typical buried iron or steel, experience has shown that maintaining a potential difference between the protected surface and the reference cell of -0.85 volt or more generally provides protection even in the most corrosive soils. Values of -0.7 or -0.5 volt may be effective protection in less corrosive soil conditions.[6.3]

\section{Factors Affecting Current Requirements and Aging}

Metallic components with corrosion prevention coatings require less current than uncoated components. When flaws (cracks, blisters, etc.) occur, the protective current is directed to the flawed areas where the most cathodic protection is required. As more of the metallic surface becomes exposed, higher current levels are required to maintain optimum protection. Several factors affecting current requirements are the following:

- Soil resistivity depends upon such factors as moisture content and acidity, and can be tested at the desired sites before system design and installation using a galvanometer.

- Polarization will gradually tend to reduce the protective current requirements.

- Accumulation of dissolved oxygen from cathode de-polarization will increase the protective current requirements due to increased resistance of the oxygen.

- Cathodic inhibitors, which prevent the deposition of salts, rust, and silt in tank protection applications, decrease the protective current requirements. 


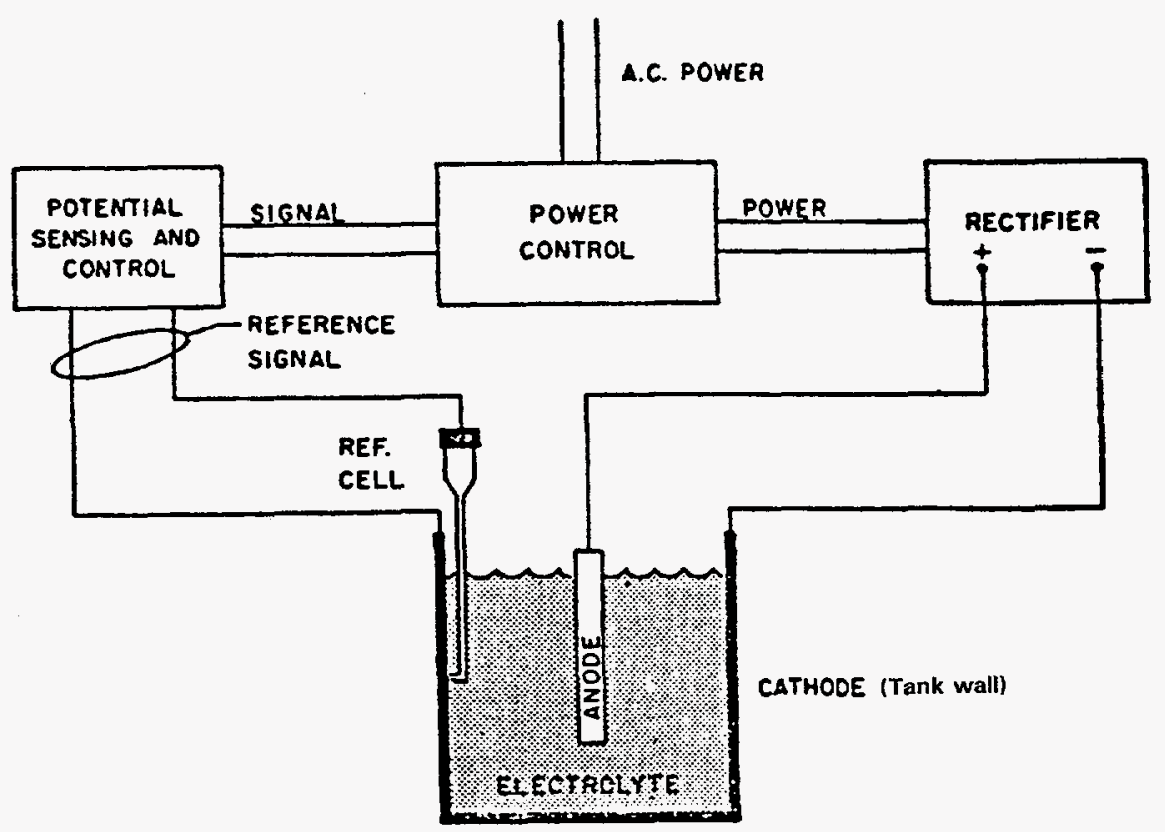

Schematic diagram for automatic potential control systems.

Figure 6-2. Schematic Diagram for Automatic Potential Control Systems (Cathodic Protection System). 
- Coating degradation will cause an increase in current requirements. Physical inspections are required to determine the onset of corrosion when increased current requirements are indicative of degraded protective coating conditions.

Other maintenance considerations include:

\section{Gas Blocking}

Gas blocking (gas from a low anodal corrosion rate) increases the protective current demands. This is a minor problem when using continuous steel anodes. Proper gas venting is required. The increased current demand can also be attributed to low ground moisture levels.

Anode Lead Wire Insulation, or Lead Wire-to-Anode Connections

Major problems have historically come from failures of anode lead wire insulation and/or lead wire-to-anode connections, resulting in a complete loss of the anode. Physical degradation of these parts is due to severe environmental conditions or installation damage, and should be monitored to maintain optimum operation of the system. (Not applicable to steel anodes.)

Anodes

Non-sacrificial anodes used in impressed current systems are not usually the limiting determinant for effective service life, even though the corrosion rate of steel anodes should be monitored. Incompatible selection of anode material for the environmental conditions is the primary cause of anode failures due to abnormal corrosion.

Other recommended inspections include:

- Rectifier checks: output and adjustments

- Tank/Structure-to-earth potentials to verify that the protection works (for nonautomatic systems)

- Physical inspection after construction to check for damage to the system equipment

\subsubsection{Galvanic (Sacrificial) Anodes}

The galvanic (sacrificial) anode method uses a metal which, because of its relative position in the galvanic series, provides sacrificial protection to a metal or metals that are more noble in the series, when coupled with an electrolyte. Typical anode metals are magnesium, aluminum, and zinc.[6.4] These anodes are the current source in this type of cathodic protection.

The anode is gradually consumed at a rate proportional to the current discharged. Typical consumption rates are one kilogram per 1100 ampere hours (Ahrs) [ $1 \mathrm{lb}$ per $500 \mathrm{Ahrs}$ ] for magnesium and one kilogram per 740 Ahrs $[1 \mathrm{lb}$ per 335 Ahrs] for zinc, in properly alloyed anodes in prepared backfill. 
This design is typically preferred for single component applications when electrical power is not economically feasible or available, and may be preferred when low current requirements are anticipated.[6.5]

\section{Factors Affecting Aging}

The effective life of sacrificial anodes is directly dependent upon the installation factors. These factors are:

1. Size (weight) of the selected anodes.

2. Amount of minimum current required from the anodes for adequate corrosion protection (Figure 6-3).

3. Spacing and number of anodes.

4. Soil resistivity.

Periodic monitoring is required to track and trend the changing parameters; some changes accelerate the consumption rate of the sacrificial anodes. An example may be where a tank coating develops flaws, cracks, and blisters. This causes a higher current on the anode, accelerating its consumption. As the size (weight) of the anode decreases, its ability to provide the required (increasing) current decreases. Most of these factors are taken into account during the initial design of the protection.

Figures 6-4 and 6-5 show a determination of anode size with expected anode life, based upon current flow, $85 \%$ of anode material consumed at end of life, and soil resistivity. Table 6-1 shows typical consumption rates of zinc, magnesium, and aluminum materials.

Significance to Aging Management

The two main power plant applications for impressed current cathodic protection systems are on structures (rebar, piping and steel liners) and buried tanks.

As discussed above, impressed current cathodic protection systems service life is more dependent upon proper operation and maintenance than the degradation of the system itself. Proper maintenance includes periodic:

- Inspection of the non-sacrificial anodes (usually steel alloys and graphite) for evidence of detrimental corrosion.

- Calibration of the automatic potential control system.

- Inspection of anode lead degradation.

Abnormal increases in current demands would be indicative of the above potential degradations, and would warrant investigation and appropriate rework. 


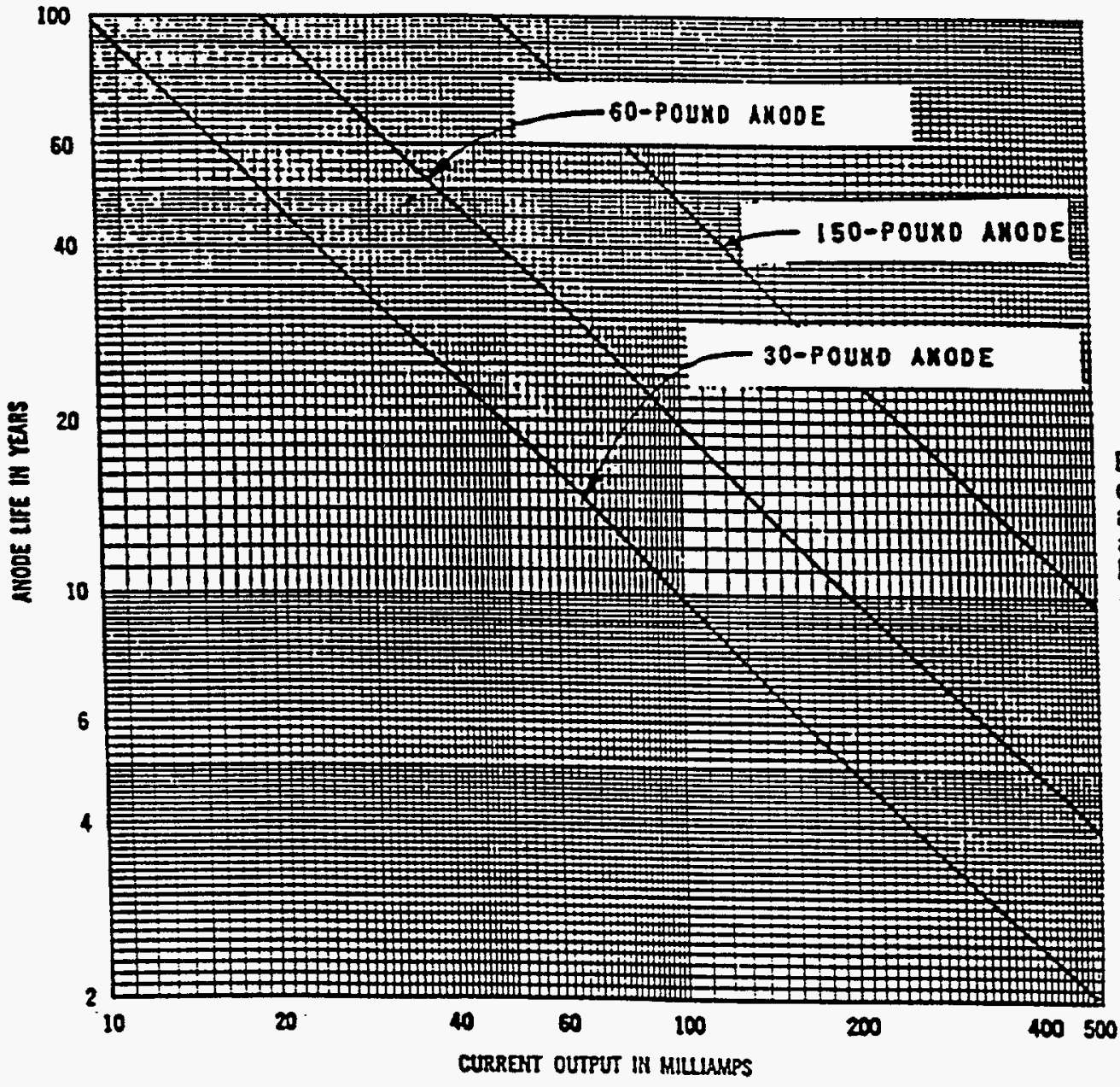

UFE OF ZNC ANODE

GROUND ROOS

VS CURREYT OUTPUT
Extend range of chart by direct proportion. For example, life of 150-pound anode at $700 \mathrm{ma}$ ortut is half that at $350 \mathrm{ma}$ of 137 $\div 2=6.85$ years, etc.
NOTE:

Curves based os zine anodes installed in suitula backfill perraitting uniform consums tion at $90 \%$ currat etficien T. Anode lif anded ter. minated when $85 \%$ of material has been

Figure 6-3. Life of Zinc Anode vs. Current Output.[6.2] 


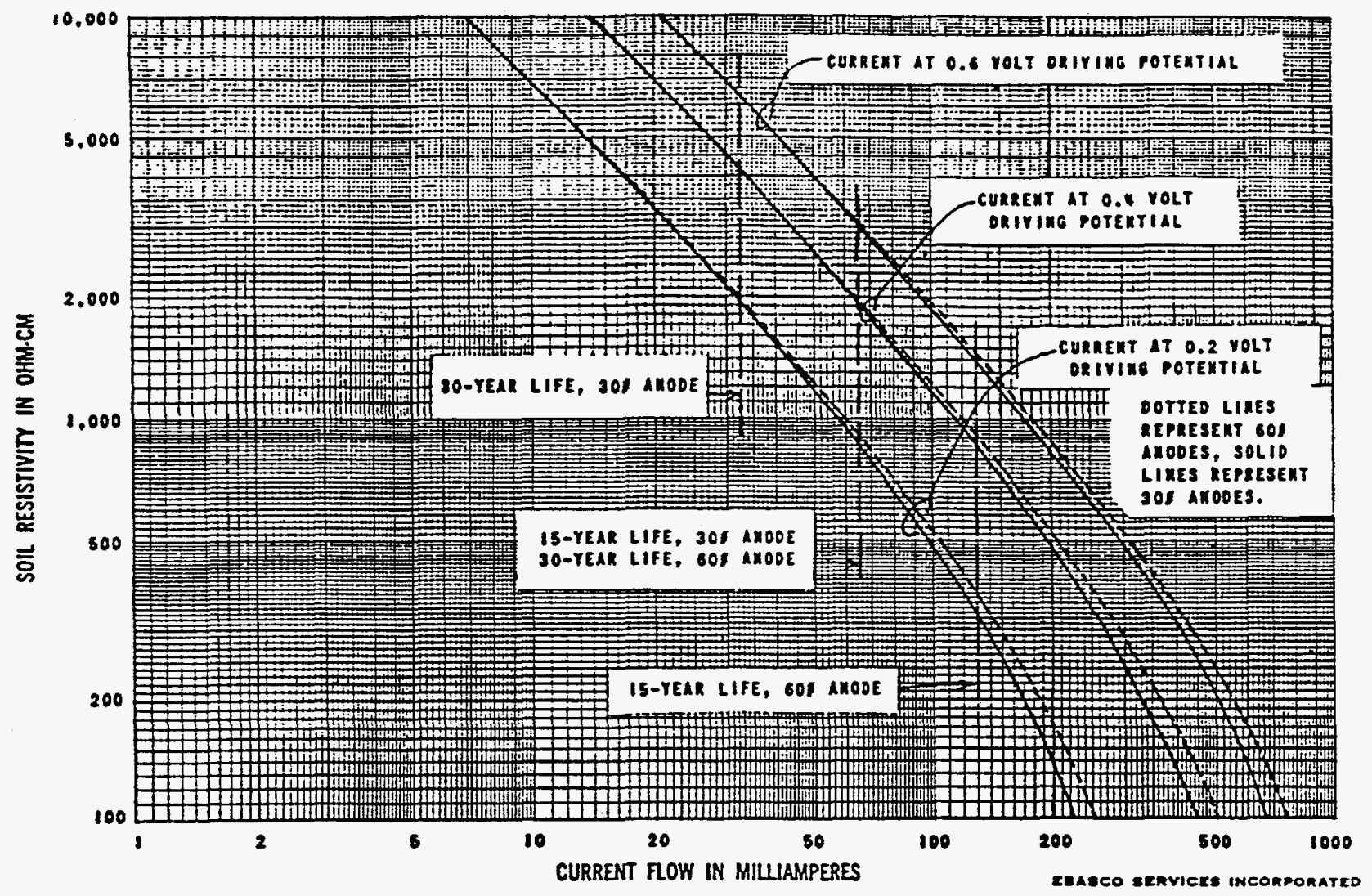

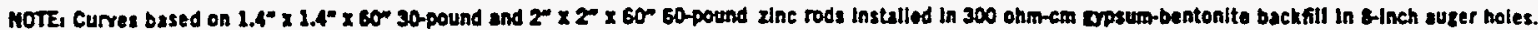

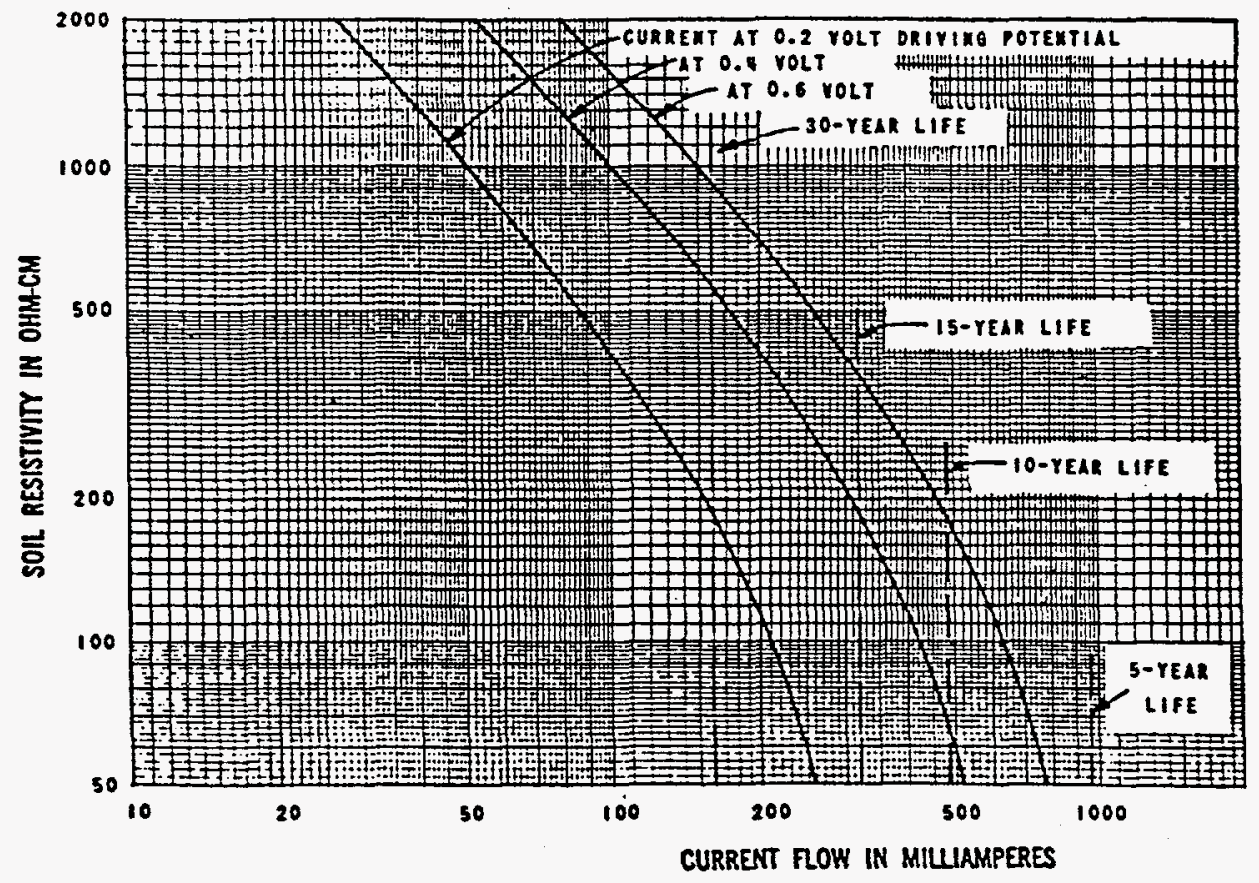

CURRET nOW

IF MIUUAMPERES

NOTE! Curres are based on 4* 35* 150-pound ane anode Installed in 300 ohm-em mpsum bentonite backfill In 20-inch ofameter aucer toles.

Figures 6-4 and 6-5. Current Outputs of Zinc Anodes as a Function of Soil Resistivity and Driving Potential.[6.2] 


\begin{tabular}{l|c|c|c}
\hline \hline \multicolumn{1}{l|}{ Table 6-1. Typical Galvanic Anode Material Consumption Rates } \\
\hline \hline & Volts & $\begin{array}{c}\mathrm{amp} / \mathrm{hr} / \mathrm{kg} \\
{[\mathrm{am} / \mathrm{hr} / \mathrm{lb}]}\end{array}$ & $\begin{array}{c}\text { kg/amp/year } \\
{[\mathrm{lb} / \mathrm{amp} / \text { year] }}\end{array}$ \\
\hline Zinc & -1.03 & $780[355]$ & $11.4[25]$ \\
\hline Magnesium & -1.43 & $1100[500]$ & $7.7[17]$ \\
\hline Aluminum, HP-7* & -1.13 & $2420[1100]$ & $3.6[8]$ \\
\hline *Material grade used in salt water applications only. \\
\hline
\end{tabular}

The service life of a galvanic (sacrificial) anode system is more predictable, due to its passive design and operation. Service life is usually determined in the original design based upon available installation parameter values (e.g., soil resistivity, anode material, and current output requirements). Periodic parameter monitoring and trending can indicate the impact of the changing parameters upon the original service life design requirements.

\subsection{Environmental Considerations}

In recent years, significant environmental performance requirements have been imposed due to leaking storage tanks. The following environmental requirements apply to storage tanks:

\section{Type of Tank}

Underground Storage Tank (UST)

Above-ground Storage Tank (AST)

\section{Environmental Legislation}

Resource Conservation and Recovery Act - 1984

Spill Prevention, Control and Counter Measures - 1990

\subsubsection{Underground Storage Tanks (UST)}

The 1984 Resource Conservation and Recovery Act (RCRA)[6.6] regulates USTs containing petroleum products and substances defined in the Comprehensive Environmental Response, Compensation, and Liability Act (CERCLA).[6.7] RCRA Subtitle I sets the federal regulations for UST operations (40 CFR Part 280).[6.8] These regulations address:

- Construction;

- Leak detection;

- Spill/overfill protection;

- Corrosion protection;

- Tank abandonment/closure;

- Release assessment/remediation; and

- Reporting and record keeping. 
All states also regulate USTs, with many adopting the federal UST regulations verbatim. States have individual policies and procedures for the assessment and remediation of UST releases. Many county and city governments also regulate USTs, often more stringently than the state and federal standards. For these reasons, it is essential to evaluate all applicable requirements when devising a UST program.

\section{UST Corrosion Protection Upgrading}

Proper operation and maintenance of corrosion protection systems can reduce the frequency of releases from UST systems due to corrosion. However, most existing tanks are not equipped with inventory control or leak detection devices. Most industry legislation pertaining to USTs allows three methods of tank upgrading for corrosion protection. [6.9] The first option is to internally line the tank according to the provisions of the regulation. Using this as the sole method requires inspection of the tank lining at preset intervals, as set forth in the regulation. The second option is to retrofit a cathodic protection system to the tank. A cathodic protection system does not require an external dielectric coating, but otherwise must be designed to the specifications of a new cathodic protection system for a new UST system. The final option is to both cathodically protect and interior line the tank. This option provides for corrosion protection on both the interior and exterior of the tank wall.

\subsubsection{Above-ground Storage Tanks (AST)}

The Spill Prevention, Control, and Countermeasures (SPCC) [6.10] program is probably the most widely known AST regulation, and many owners and operators are required to conform with the existing 40 CFR 112 SPCC rules. These rules are part of the Oil Pollution Act of 1990 (OPA).[6.11]

SPCC plan rules apply only to those facilities that could reasonably discharge oil to a navigable waterway and that contain the following storage capacities:

- UST capacity of more than 42,000 gallons, or

- Aggregate AST capacity of more than 1320 gallons, or

- Single AST capacity of more than 660 gallons.

ASTs include bunkered or partially buried tanks that may be regulated under RCRA Subtitle I as USTs.

Most ASTs will require SPCC plans based on tank volume/size. The determining factor is typically a threat to a navigable waterway. Any facility located close to a stream, tributary, lake or even storm drain that discharges into a stream may require an SPCC plan. (There have been reported instances of gopher holes being assigned "navigable waterway" status because they ultimately discharge to an intermittent stream.) Manmade secondary containment typically is not considered when making this determination.

There are many guidance documents for preparing SPCC plans. The API Suggested Procedure for Development of Spill Prevention Control and Countermeasure Plans is one (API Bulletin D16).[6.12] 


\subsubsection{Environmental Performance Requirements}

Table 6-2 provides a summary of environmental performance requirements and regulatory concerns for various tank configurations.

Table 6-2. Environmental Considerations for Storage Tanks

\begin{tabular}{|c|c|c|}
\hline Tank Configuration & Performance Requirement & Regulatory Concerns \\
\hline $\begin{array}{l}\text { AST: Single-wall steel with } \\
\text { catchment basin }\end{array}$ & N/A & $\begin{array}{l}\text { Generally not allowed for extremely } \\
\text { flammable liquids. Possible National } \\
\text { Pollutant Discharge Elimination System } \\
\text { (NPDES) discharge issues, possible } \\
\text { SPCC. }\end{array}$ \\
\hline AST: Double-wall & N/A & None found. \\
\hline $\begin{array}{l}\text { UST: Single-wall steel tank with } \\
\text { cathodic protection }\end{array}$ & $\begin{array}{l}\text { - Automatic tank gauging } \\
\text { - Lined tank pit with } \\
\text { monitoring wells } \\
\text { - Vapor sensors in wells } \\
\text { - Groundwater } \\
\text { monitoring } \\
\end{array}$ & $\begin{array}{l}\text { Some areas will not allow steel tanks. } \\
\text { State and federal UST regulations apply. }\end{array}$ \\
\hline UST: Single-wall fiberglass tank & $\begin{array}{l}\text { - Automatic tank gauging } \\
\text { - Lined tank pit with } \\
\text { monitoring wells } \\
\text { - Vapor sensors in wells } \\
\text { - Groundwater } \\
\text { monitoring } \\
\end{array}$ & $\begin{array}{l}\text { Some areas may not allow single-wall } \\
\text { tanks. State and federal UST regulations } \\
\text { apply. }\end{array}$ \\
\hline $\begin{array}{l}\text { UST: Single-wall steel } \\
\text { fiberglass-clad }\end{array}$ & $\begin{array}{l}\text { - Automatic tank gauging } \\
\text { - Lined tank pit with } \\
\text { monitoring wells } \\
\text { - Vapor sensors in wells } \\
\text { - Groundwater } \\
\text { monitoring } \\
\end{array}$ & $\begin{array}{l}\text { Some areas may not allow single-wall } \\
\text { tanks. State and federal UST regulations } \\
\text { apply. }\end{array}$ \\
\hline $\begin{array}{l}\text { UST: Double-wall steel tank with } \\
\text { cathodic protection }\end{array}$ & $\begin{array}{l}\text { Interstitial monitoring (can } \\
\text { add options above for } \\
\text { added safety) }\end{array}$ & $\begin{array}{l}\text { Readily accepted by most localities. } \\
\text { State and federal UST regulations apply. }\end{array}$ \\
\hline UST: Double-wall fiberglass tank & Interstitial monitoring & $\begin{array}{l}\text { Readily accepted by most localities. } \\
\text { State and federal UST regulations apply. }\end{array}$ \\
\hline
\end{tabular}

\subsection{Use of Composite Tanks}

Fiber-reinforced plastic (FRP) tanks and pressure vessels (henceforth both called "vessels") have been specified in many recent applications due to environmental concerns, as a materials enhancement for a degraded tank, or a combination of both. The most frequent use for a FRP tank is in the underground storage of petroleum products and above-ground storage 
of harsh chemicals. This type of tank was not included in the aging evaluation of Section 4 since no FRP tanks were found during the host utility surveys.

The use of FRPs for the manufacture of pressure vessels presents unique materials considerations in the design, fabrication, and testing of these vessels. Metallic vessels, being made from materials that are normally isotropic and ductile, are designed by using wellestablished allowable stresses based on measured tensile and ductility properties. In contrast, FRPs are usually anisotropic and the physical properties are dependent upon the fabrication process, the placement and orientation of the reinforcement, and the resin matrix. There are three principal codes and standards that govern the design, fabrication, and testing of FRP tanks:

1. ASME Section X, Fiber-Reinforced Plastic Pressure Vessels [6.13]

2. ASTM D4021, Standard Specification for Glass-Fiber-Reinforced Polyester Underground Petroleum Storage Tanks [6.14]

3. ANSI/UL 1316, UL Standard for Safety Glass-Fiber-Reinforced Plastic Underground Storage Tanks for Petroleum Products, Alcohols and Alcohol-Gasoline Mixtures [6.15]

Due to the very specific applications of the later two standards, ASME Section X will be used as a guide for some of the more general requirements/considerations for FRP design, fabrication and test provided in the paragraphs that follow.

\section{Design}

It is not possible to fabricate a FRP vessel of a single basic material for which there is an ASTM specification. The vessel parts are made up of various basic materials, such as fiber reinforcement and resin, which are joined in the presence of a catalyst to create a composite material that is formed into a vessel or vessel part by a specified process. The composite material will often have directional properties that must be considered in design. General specifications for the basic materials (fiber reinforcement and resin) are stated in Section X, as are requirements for determination of elastic properties for the composite material (laminate) produced. Elastic properties of specific laminates used in vessel fabrication are required when mandatory rules are used for vessel design. Metallic materials, when used in conjunction with reinforced fiber laminates, are required to meet ASME Section VIII, Division 1. That Section must be used in its entirety, including design, fabrication, quality control, and inspection of such metallic parts.

Adequacy of a specific design shall be qualified by one of two basic methods (these two methods shall not be intermixed):[6.13]

(a) Class I Design-qualification of a vessel design through the pressure testing of a prototype; or

(b) Class II Design-mandatory design rules and acceptance testing by nondestructive methods. 
Class I designs based on the qualification of a prototype vessel require that the minimum qualification pressure of the prototype be at least six times the design pressure. (An exception to this six times factor is applicable to vessels per Article RG-404.2 [Filament Winding - With Uncut Filaments].) The maximum design pressure is limited to 150 psi for bag-molded, centrifugally cast, and contact-molded vessels, 1500 psi for filament-wound vessels with cut filaments; and 3000 psi for filament-wound vessels with uncut filaments (ports on axis of rotation only).

Class II designs based on mandatory design rules and acceptance testing must comply with Article RD-11 and Article RT-6. The maximum design pressure allowed under this procedure shall be specified in RD-1120.

FRP laminates may have a modulus of elasticity as low as $1.0 \times 10^{6} \mathrm{psi}$. This low modulus characteristic requires careful consideration of vessel mounting and shape in order to minimize bending and avoid buckling. Spherical heads or elliptical heads having an ellipse ratio not greater than 2:1 are suggested. Spherical heads are suggested when the material has isotropic properties. Elliptical heads are preferred when the material has anisotropic properties.

\section{Fabrication}

Many processes are used in the fabrication of FRP materials (laminates). Class I vessels are limited to four processes, namely, filament winding, bag molding, contact molding, and centrifugal casting. Class II vessels are limited to two processes, namely, filament winding and contact molding.

The fabrication of more than one Class I vessel may be required to comply with the requirements for qualifying a design using the prototype vessel method. Once a specific design has been qualified, the quality of subsequent vessels of the same dimension and design is to be assured by carefully controlled fabrication procedures and rigid Quality Control Programs.

Every Class II vessel must be acceptance tested as specified in Article RT-6. Such tests must be documented as having met the acceptance criteria of Article RT- 6 and shall become part of the Fabricator's Design Report.

\section{Inspection}

The general philosophy of ASME Section VIII, Division 1, regarding inspection during fabrication is carried over into ASME Section X. Familiarity with the laminate production processes and the nature of vessel imperfections is required of the Inspector. Reliance is placed upon careful auditing of the Fabricator's Quality Control Program, close visual inspection of completed vessels by both Fabricator personnel and the Inspector, and acceptance testing where required by this Section.

Section $\mathrm{X}$ requires that all laminate and secondary bonding work be without use of pigments, fillers, or resin putty mixtures except as permitted by the Procedure Specification used in fabricating the vessel or vessel part. 


\section{Liners}

Liners may be used in ASME Section X vessels as a barrier between the laminate and the vessel contents. If used, such liners shall not be considered part of the structural component of the vessel.

\section{Aging Considerations}

FRP tanks are chosen for their light weight and superior corrosion resistance. If the FRP composite materials and resins are selected properly based on the specific application (material to be stored and environment it is stored in), the FRP tank will have negligible aging degradation. However, there are several aging considerations that must be accounted for in the design and use of FRP tanks as discussed below.

\section{Fatigue}

Like metallic materials, the composite material (laminate) of FRP vessels, when stressed at sufficiently low levels, exhibits good fatigue life. However, its low modulus of elasticity provides a higher strain per unit of stress than metals used for metallic vessels. ASME Section $\mathrm{X}$, therefore, requires that a Class I design that is qualified by testing of a prototype vessel be pressure cycled 100,000 times over a pressure range of atmospheric to the design pressure. After this, the test vessel must withstand a hydrostatic qualification test not less than six times the design pressure.

An exception to this 100,000 cycle requirement is applicable to vessels per ASME Section X, Article RG-404.2.[6.13] That classification of vessels is designed for a 5:1 factor of safety which requires cycling from atmospheric to the design pressure for 33,000 cycles. After this, the test vessel must withstand a hydrostatic qualification test not less than five times the design pressure.

Class II vessels qualified using mandatory design rules and acceptance testing are not required to be subjected to the above cyclic and qualification pressure test criteria.

\section{Creep and Stress-Rupture}

FRP composite material (laminate) is not subject to creep or stress-rupture failure due to low stress-rupture characteristics as compared with other materials.

\section{Temperature Effects}

FRP materials lose ultimate strength as their temperature is increased and gain strength (but become more brittle) as their temperature is lowered. The low thermal conductivity and ablative properties of FRP materials are other factors significantly affecting the behavior of these materials in the event of fire or other high-temperature environments. 
The maximum design, operating, and test temperatures of Class I vessels are set at $65^{\circ} \mathrm{C}\left[150^{\circ} \mathrm{F}\right]$. The maximum design, operating, and test temperatures of Class II vessels are limited to an inside wall temperature of $120^{\circ} \mathrm{C}\left[250^{\circ} \mathrm{F}\right]$ or to within $19^{\circ} \mathrm{C}$ $\left[35^{\circ} \mathrm{F}\right]$ of the glass transition temperature of the resin (whichever is lower). The minimum design temperature of both Class I and Class II vessels shall be $-54^{\circ} \mathrm{C}\left[-65^{\circ} \mathrm{F}\right]$ (see RD-122 [6.13]).

There are three other significant factors that affect the life of a FRP tank that cannot necessarily be controlled by design. These are tank installation, tank contents, and tank environment.

\section{Tank Installation}

Due to its relatively low strength and its anisotropic properties, it is critical that an FRP tank be mounted and anchored in accordance with design specifications. This is not necessarily an age-related issue, but improper installation/anchoring has accounted for many of the known FRP tank failures.

\section{Tank Contents}

Generally, the tank materials will have been specified with the tank contents in mind with special consideration of tank operating temperature as discussed above. There is a large variation in the possible materials for use in tank fabrication and/or tank liners making it possible to ensure long-term compatibility of tank and contents. However, it is incumbent upon the owner to ensure tank contents stay within the design specifications since the resulting attack on the tank materials can be catastrophic, leading to softening and/or delamination of the pressure boundary.

\section{Tank Environment}

The tank environment is important in that it factors into the tank temperature, as discussed previously, but also as it relates to other possible degradations. One significant degradation of concern for FRP tanks located outside is the loss of material properties brought on by long-term exposure to the sun's ultraviolet rays. To avoid this phenomenon, measures should be taken to isolate the tank from direct sunlight either by enclosing the tank or coating it.

\subsection{Pulsed Infrared Imaging Inspection of AST}

Pulsed infrared imaging (PII) is a new materials inspection technology that provides several advantages for detecting and quantifying corrosion degradation. The PII technique involves "providing heat, by means of a pulse, and dynamically collecting infrared images of the material surface."[6.16] Two variables depend on the thermal characteristics of the material: heat intensity and duration. A successful test involves supplying heat at the top surface of the material and allowing it to penetrate through the material to the bottom surface. The $\Delta T$ to the bottom surface needs to be in the order of several degrees to allow for good infrared contrast. Heat penetration time is the main factor in the infrared acquisition time; the larger a 
piece of steel, the longer the heat penetration time, and a subsequently longer infrared acquisition time.

"The infrared images are collected in frames in a time sequence. The flaws show up in the time sequence according to their depth. If there were two areas with corrosion, one deeper than the other, the deeper pit (the one with the most material loss) would show up in an earlier image frame than the less corroded area. Because of this time history relationship, it is possible to calculate material loss. "[6.16]

The advantages of this new technology are:

- This is an optical method, so no contact with the device is necessary

- Large areas can be tested quickly (including over welded joints). Testing time is usually several seconds.

- The test area need not be smooth or rust-free, and the system works well with most tank coatings

- No ionizing radiation or toxic chemicals are needed

- Hard copy and data archival are immediately available

- The infrared images resemble X-ray images. This makes it easy to correlate defects.

\subsection{Eddy Current and Magnetic Flux Leakage of Tank Bottoms}

Magnetic Flux Leakage (MFL) test technology has been applied to the inspection of above-ground storage tank bottoms since the late 1980s. Corrosion in flat carbon steel tank floor plates up to $10 \mathrm{~mm}$ thick could be detected using this technique. "The application of MFL test technology to the inspection of AST floor plats has been shown to be a viable means of achieving up to $95 \%$ test coverage of the tank floor within a reasonable amount of time. Examination of the tank floors previously depended primarily upon ultrasonic test methods that required slow and painstaking application. A continuous oil or water based couplant has to be maintained constantly between the transducer and the plate being inspected. A track mounted inspection of a $55 \mathrm{~m}$ diameter tank, for example, would take about five weeks to complete. "[6.17]

MFL-type nondestructive methods have long been in use to inspect tube and wire products. The method detects anomalies in normal flux patterns created by discontinuities in ferrous material saturated by a magnetic field. The requirements for magnetic saturation depend on the specific test application. For example, a relatively low magnetization (about 2 to 3 times the coercivity of the material to be inspected) is sufficient for top surface inspection. For a subsurface or back surface inspection, however, a near saturation magnetic flux field in the material is needed to produce a flux leakage significant enough for detection.

\subsection{References}

6.1 Crennel, J. R., "Cathodic Protection," The MacMillan Co., 1960.

6.2 "Zinc as a Galvanic Anode... Underground," American Zinc Institute, Inc., 1969. 
6.3 "Recommended Practice - Design, Installation, Operation, and Maintenance of Impressed Current Deep Groundbeds," NACE Standard RP-05-72, Revision 1985.

6.4 "Cathodic Protection," Water and Wastes Engineering, October 1966.

6.5 "Recommended Practices - Design, Installation, Operation, and Maintenance of Internal Cathodic Protection Systems in Oil Treating Vessels," NACE Standard RP-05-75, 1975.

6.6 Resource Conservation and Recovery Act (RCRA), passed as part of the Hazardous and Solid Waste Amendments of 1984, Public Law 98-616, enacted November 8, 1984.

6.7 Comprehensive Environmental Response, Compensation, and Liability Act (CERCLA), RCRA Subtitle I.

6.8 40 CFR Part 280, Underground Storage Tanks: Technical Requirements; Final Rule, 1991.

6.9 Underground Storage Tanks, Thompson Publishing Group, September 1994.

6.10 40 CFR Part 112, Clean Water Act: Spill Prevention, Controls, and Countermeasures (SPCC) Plans, 1990.

6.11 OPA 90, Oil Pollution Act of 1990.

6.12 "Suggested Procedure for Development of Spill Prevention Control and Countermeasure Plans," API Bulletin D16, American Petroleum Institute, 1989.

6.13 American Society of Mechanical Engineers (ASME) Boiler and Pressure Vessel Code, Section X, Fiber-Reinforced Plastic Pressure Vessels, 1994.

6.14 ASTM D4021, Standard Specification for Glass-Fiber-Reinforced Plastic Underground Petroleum Storage Tanks, 1992.

6.15 ANSI/UL 1316, UL Standard for Safety Glass-Fiber-Reinforced Plastic Underground Storage Tanks for Petroleum Products, Alcohols and AlcoholGasoline Mixture, 1994.

6.16 Bales, M. J., and C. C. Bishop, "Pulsed Infrared Imaging: A New NDT Methodology for Aboveground Storage Tanks," Materials Evaluation, July 1994.

6.17 You, Z., and D. Bauer, "Combining Eddy Current and Magnetic Flux Leakage for Tank Floor Inspection," Materials Evaluation, July 1994. 



\section{APPENDIX A DEFINITIONS ${ }^{1}$}

accelerated aging artificial aging in which the simulation of natural aging approximates, in a short time, the aging effects of longer-term service conditions

acceptance criterion specified limit of a functional or condition indicator used to assess the ability of an $\mathrm{SSC}^{*}$ to perform its design function

age (noun) time from fabrication of an SSC to a stated time

age conditioning simulation of natural aging effects in an SSC by the application of any combination of artificial and natural aging

age-related degradation synonym for aging degradation

aging (noun) general process in which characteristics of an SSC gradually change with time or use

aging assessment evaluation of appropriate information for determining the effects of aging on the current and future ability of SSCs to function within acceptance criteria

aging degradation aging effects that could impair the ability of an SSC to function within acceptance criteria

aging effects net changes in characteristics of an SSC that occur with time or use and are due to aging mechanisms

aging management engineering, operations, and maintenance actions to control within acceptable limits aging degradation and wearout of SSCs

aging mechanism specific process that gradually changes characteristics of an SSC with time or use

artificial aging simulation of natural aging effects on SSCs by application of stressors representing plant pre-service and service conditions, but perhaps different in intensity, duration, and manner of application

breakdown synonym for complete failure

characteristic property or attribute of an SSC (such as shape, dimension, weight, condition indicator, functional indicator, performance or mechanical, chemical, or electrical property)

* $\mathrm{SSC}=$ system, structure, or component 
combined effects net changes in characteristics of an SSC produced by two or more stressors common cause failure two or more failures due to a single cause common mode failure two or more failures in the same manner or mode due to a single cause complete failure failure in which there is complete loss of function

condition the state or level of characteristics of an SSC that can affect its ability to perform a design function

condition surrounding physical state or influence that can affect an SSC

condition indicator characteristic that can be observed, measured, or trended to infer or directly indicate the current and future ability of an SSC to function within acceptance criteria

condition monitoring observation, measurement, or trending of condition or functional indicators with respect to some independent parameter (usually time or cycles) to indicate the current and future ability of an SSC to function within acceptance criteria

condition trending synonym for condition monitoring

corrective maintenance actions that restore, by repair, overhaul, or replacement, the capability of a failed SSC to function within acceptance criteria

degradation immediate or gradual deterioration of characteristics of an SSC that could impair its ability to function within acceptance criteria

degraded condition marginally acceptable condition of an unfailed SSC that could lead to a decision to perform planned maintenance

degraded failure failure in which a functional indicator does not meet an acceptance criterion, but design function is not completely lost

design basis conditions synonym for design conditions

design basis event any of the events specified in the station's safety analysis that are used to establish acceptable performance for safety-related functions of SSCs; events include anticipated transients, design basis accidents, external events, and natural phenomena

design basis event conditions service conditions produced by design basis events

design basis event stressor stressor that stems from design basis events and can produce immediate or aging degradation beyond that produced by normal stressors 
design conditions specified service conditions used to establish the specifications of an SSC (generally includes margin of conservatism beyond expected service conditions)

design life period during which an SSC is expected to function within acceptance criteria design service conditions synonym for design conditions

deterioration synonym for degradation

diagnosis examination and evaluation of data to determine either the condition of an SSC or the causes of the condition

diagnostic evaluation synonym for diagnosis

environmental conditions ambient physical states surrounding an SSC

error-induced aging degradation aging degradation produced by error-induced conditions

error-induced conditions adverse pre-service or service conditions produced by design, fabrication, installation, operation, or maintenance errors

error-induced stressor stressor that stems from error-induced conditions and can produce immediate or aging degradation beyond that produced by normal stressors

failure inability or interruption of ability of an SSC to function within acceptance criteria

failure analysis systematic process of determining and documenting the mode, mechanism, causes, and root cause of failure of an SSC

failure cause circumstances during design, manufacture, test, or use that have led to failure

failure evaluation synonym for failure analysis

failure mechanism physical process that results in failure

failure mode the manner or state in which an SSC fails

failure modes and effects analysis systematic process for determining and documenting potential failure modes and their effects on SSCs

failure trending recording, analyzing, and extrapolating in-service failures on an SSC with respect to some independent parameter (usually time or cycles)

functional conditions influences on an SSC resulting from the performance of design functions (operation of a system or component and loading of a structure) 
functional indicator condition indicator that is a direct indication of the current ability of an SSC to function within acceptance criteria

inservice inspection methods and actions for assuring the structural and pressure-retaining integrity of safety-related nuclear power plant components in accordance with the rules of this Section [ASME Code, Section XI]

inservice life synonym for service life, (especially in discussions involving ASME Code Section $\mathrm{XI})$

inservice test a test to determine the operational readiness of a component or system [ASME Code, Section XI]

inspection synonym for surveillance

installed life period from installation to retirement of an SSC

life period from fabrication to retirement of an SSC

life assessment synonym for aging assessment

life cycle management synonym for life management

life management integration of aging management and economic planning to: (1) optimize the operation, maintenance, and useful life of SSCs; (2) maintain an acceptable level of performance and safety; and (3) maximize return on investment over the useful life of the plant

lifetime synonym for life

maintenance aggregate of direct and supporting actions that detect, preclude, or mitigate degradation of a functioning SSC, or restore to an acceptable level the design functions of a failed SSC

malfunction synonym for failure

mean time between failures arithmetic average of operating times between failures of an item [IEEE Std 100]

natural aging aging of an SSC that occurs under pre-service and service conditions, including error-induced conditions

normal aging natural aging from error-free pre-service or service conditions normal aging degradation aging degradation produced by normal conditions 
normal conditions operating conditions of a properly designed, fabricated, installed, operated and maintained SSC excluding design basis event conditions

normal operating conditions synonym for normal conditions

normal stressor stressor that stems from normal conditions and can produce aging mechanisms and effects in an SSC

operating conditions service conditions, including normal and error-induced conditions, prior to the start of a design basis accident or earthquake

operating service conditions synonym for operating conditions

operational conditions synonym for functional conditions

overhaul (noun) extensive repair, refurbishment, or both

performance indicator synonym for functional indicator

periodic maintenance form of preventive maintenance consisting of servicing, parts replacement, surveillance, or testing at predetermined intervals of calendar time, operating time, or number of cycles

planned maintenance form of preventive maintenance consisting of refurbishment or replacement that is scheduled and performed prior to failure of an SSC

post-maintenance testing testing after maintenance to verify that maintenance was performed correctly and that the SSC can function within acceptance criteria

preconditioning synonym for age conditioning

predictive maintenance form of preventive maintenance performed continuously or at intervals governed by observed condition to monitor, diagnose, or trend an SSC's functional or condition indicators; results indicate current and future functional ability or the nature and schedule for planned maintenance

premature aging aging effects of an SSC that occur earlier than expected because of errors or pre-service and service conditions not considered explicitly in design

pre-service conditions actual physical states or influences on an SSC prior to initial operation (e.g., fabrication, storage, transportation, installation, and pre-operational testing)

preventive maintenance actions that detect, preclude, or mitigate degradation of a functional SSC to sustain or extend its useful life by controlling degradation and failures to an acceptable level; there are three types of preventive maintenance: periodic, predictive, and planned. 
qualified life period for which an SSC has been demonstrated, through testing, analysis, or experience, to be capable of functioning within acceptance criteria during specified operating conditions while retaining the ability to perform its safety functions in a design basis accident or earthquake

random failure any failure whose cause or mechanism, or both, make its time of occurrence unpredictable [IEEE Std 100]

reconditioning synonym for overhaul

refurbishment planned actions to improve the condition of an unfailed SSC

remaining design life period from a stated time to planned retirement of an SSC

remaining life actual period from a stated time to retirement of an SSC

remaining service life synonym for remaining life

remaining useful life synonym for remaining life

repair actions to return a failed SSC to an acceptable condition

replacement removal of an undegraded, degraded, or failed SSC or a part thereof and installation of another in its place that can function within the original acceptance criteria

residual life synonym for remaining life

retirement final withdrawal from service of an SSC

rework correction of inadequately performed fabrication, installation, or maintenance

root cause fundamental reason(s) for an observed condition of an SSC that if corrected prevents recurrence of the condition

root cause analysis synonym for failure analysis

service conditions actual physical states or influences during the service life of an SSC, including operating conditions (normal and error-induced), design basis event conditions, and post design basis event conditions

service life actual period from initial operation to retirement of an SSC

servicing routine actions (including cleaning, adjustment, calibration, and replacement of consumable) that sustain or extend the useful life of an SSC

simultaneous effects combined effects from stressors acting simultaneously 
stress synonym for stressor

stressor agent or stimulus that stems from pre-service and service conditions and can produce immediate or aging degradation of an SSC

surveillance observation or measurement of condition or functional indicators to verify that an SSC currently can function within acceptance criteria

surveillance requirements test, calibration, or inspection to assure that the necessary quality of systems and components is maintained, that facility operation will be within the safety limits, and that the limiting conditions of operation will be met [10 CFR 50.36] (for use only when specific regulatory and legal connotations are called for)

surveillance testing synonym for surveillance, surveillance requirements, and testing (use only when specific regulatory and legal connotations are called for)

synergistic effects portion of changes in characteristics of an SSC produced solely by the interaction of stressors acting simultaneously, as distinguished from changes produced by superposition from each stressor acting independently

testing observation or measurement of condition indicators under controlled conditions to verify that an SSC currently conforms to acceptance criteria

time in service time from initial operation of an SSC to a stated time

useful life synonym for service life

wearout failure produced by an aging mechanism

Relationship of Aging Terms

A stressor, produces by such conditions as temperature, radiation, or voltage, acts on a component. If the component (or its materials) is sensitive to the stressor, an aging mechanism will occur.

An aging mechanism may lead to age-related degradation if the effects of the aging mechanisms that result in age-related degradation are not accounted for through such actions as maintenance.

Eventually, an aging mechanism may lead to a failure mechanism. The result of the failure mechanism is the failure mode of the component.

Review of the failure mode, failure and aging mechanisms, age-related degradation, and stressors will provide the failure cause for age-related failures. 
AGING MANAGEMENT GUIDELINE FOR TANKS AND POOLS

\section{References}

1. EPRI TR-100844, "Nuclear Power Plant Common Aging Terminology," prepared by MPR Associates, Inc., November 1992. 


\section{APPENDIX B ACRONYMS}
AM
aging mechanism
AMG
Aging Management Guideline
API
American Petroleum Institute
ASME
American Society of Mechanical Engineers
AST
above-ground storage tank
ASTM
American Society for Testing and Materials
AWWA
American Water Works Association
BW
Babcock and Wilcox
BWR
Boiling Water Reactor
CASS
cast austenitic stainless steel
$\mathrm{CC}$
component cooling water system
CCW
component cooling water system
$\mathrm{CE}$
Combustion Engineering
CERCLA Comprehensive Environmental Response, Compensation, and Liability Act
CFR
Code of Federal Regulations
$\mathrm{CH}$
chemical volume control system
CLB
current licensing basis
COND condensate system
CS chemical shutdown system
CVCS
chemical volume control system
DFO
diesel fuel oil system
DOE
Department of Energy
DW
demineralized water system
$\mathrm{E} / \mathrm{C}$
erosion/corrosion
EDG
emergency diesel generator system
EOP emergency operating procedure
EPRI
Electrical Power Research Institute
EQ
environmentally qualified
FAC
Flow-Assisted Corrosion 
FO

fuel oil system

FRP

fiberglass-reinforced plastic

FS

fire suppression system

FSAR

Final Safety Analysis Report

GE

General Electric

HPCS

high-pressure core spray

IASCC

irradiation assisted stress corrosion cracking

IE

Inspection and Enforcement (former NRC division)

IGA

intergranular attack

IGSCC

intergranular stress corrosion cracking

INPO

Institute for Nuclear Power Operations

IPA

Integrated Plant Assessment

IR

Industry Report

ISI

Inservice Inspection

LCM

Life Cycle Management

LCO

Limiting Condition of Operation

LER

Licensee Event Report

LRR

License Renewal Rule

LWR

light water reactor

MFL

Magnetic Flux Leakage

MIC

microbiologically influenced corrosion

MPFF

Maintenance Preventable Functional Failure

MR

Maintenance Rule

NACE

National Association of Corrosion Engineers

NDE

non-destructive examination

NEI

Nuclear Energy Institute (formerly NUMARC)

NFPA

National Fire Protection Association

NLPA

National Leak Prevention Association

NPDES

National Pollutant Discharge Elimination System

NPRDS

Nuclear Plant Reliability Data System

NRC

Nuclear Regulatory Commission 
NSSS nuclear steam supply system

NUMARC Nuclear Management and Resource Council (now NEI)

NUREG Nuclear Regulatory Commission Publications

OPA Oil Pollution Act of 1990

P\&ID piping and instrumentation diagram

PEI Petroleum Equipment Institute

PII pulsed infrared imaging

PM preventive maintenance

PWR Pressurized Water Reactor

PWS primary water system

PZR pressurizer system

RBCCW Reactor Building Closed Cooling Water

RCPB Reactor Coolant Pressure Boundary

RCRA Resource Conservation and Recovery Act

RWST refueling water storage tank system

SCC stress corrosion cracking

SER Significant Event Report

SF spent fuel system

SFP spent fuel pool cooling system

SI safety injection system

SOER Significant Operating Experience Report

SPCC Spill Prevention, Control, and Countermeasures

SS stainless steel

SSC system, structure, and component

SSS safe shutdown system

STI Steel Tank Institute

SW service water system

TGSCC transgranular stress corrosion cracking

TLAA time-limited aging analysis

TLIB (INPO) Technical Library Database

TMI Three Mile Island 
UL Underwriters Laboratories

UST underground storage tank

VD vent and drain system

WD waste disposal system 


\section{APPENDIX C \\ INDUSTRY CODES AND STANDARDS FOR TANKS}

\begin{tabular}{|c|c|}
\hline \multicolumn{2}{|c|}{$\begin{array}{l}\text { American Petroleum Institute (API) } \\
\text { American Petroleum Institute } \\
\text { 1220 L Street, N.W. } \\
\text { Washington, DC } 20005 \\
\text { (202) 682-8000 }\end{array}$} \\
\hline $\begin{array}{l}\text { API 12F } \\
\text { Specification for Shop Welded Tanks for } \\
\text { Storage of Production Liquids, tenth } \\
\text { edition. }\end{array}$ & $\begin{array}{l}\text { Covers design, venting requirements, } \\
\text { fabrication, testing, painting, inspection and } \\
\text { rejection of shop welded tanks. }\end{array}$ \\
\hline $\begin{array}{l}\text { API } 650 \\
\text { Welded Steel Tanks for Oil Storage, } \\
\text { eighth edition. }\end{array}$ & $\begin{array}{l}\text { Covers materials and design requirements, how } \\
\text { to fabricate and erect a steel tank, how to } \\
\text { inspect joints,' and welding and marking } \\
\text { procedures for welded steel tanks. }\end{array}$ \\
\hline $\begin{array}{l}\text { API } 653 \\
\text { Tank Inspection, Repair, Alteration, and } \\
\text { Reconstruction, First Edition, } 1991 .\end{array}$ & $\begin{array}{l}\text { Provides guidance in the inspection, repair, } \\
\text { alteration, and reconstruction of steel storage } \\
\text { tanks used in the petroleum and chemical } \\
\text { industries. The standard provides the } \\
\text { minimum requirements for maintaining the } \\
\text { integrity of welded or riveted, non-refrigerated, } \\
\text { atmospheric pressure, aboveground storage } \\
\text { tanks after they have been placed in service. }\end{array}$ \\
\hline $\begin{array}{l}\text { API } 1604 \\
\text { Removal and Disposal of Used } \\
\text { Underground Petroleum Storage Tanks, } \\
\text { second edition. }\end{array}$ & $\begin{array}{l}\text { Provides operating procedures which may be } \\
\text { used for the abandonment, removal, storage, } \\
\text { placed temporarily out of service and sale of } \\
\text { used underground tanks which have contained } \\
\text { gasoline or other flammable liquids. } 1989 \\
\text { supplement available. }\end{array}$ \\
\hline $\begin{array}{l}\text { API } 1631 \\
\text { Interior Lining of Underground Storage } \\
\text { Tanks, third edition. }\end{array}$ & $\begin{array}{l}\text { Recommends procedures for installing an } \\
\text { interior lining in underground tanks that store } \\
\text { petroleum-based motor fuels and middle } \\
\text { distillates. Covers how to prepare for tank } \\
\text { opening and entry, how to prepare tank interior } \\
\text { and apply lining, and tank closing. }\end{array}$ \\
\hline
\end{tabular}




\begin{tabular}{|c|c|}
\hline \multicolumn{2}{|c|}{$\begin{array}{l}\text { American Petroleum Institute (API) } \\
\text { American Petroleum Institute } \\
1220 \text { L Street, N.W. } \\
\text { Washington, DC } 20005 \\
\text { (202) } 682-8000\end{array}$} \\
\hline $\begin{array}{l}\text { API } 1632 \\
\text { Cathodic Protection of Underground } \\
\text { Petroleum Storage Tanks and Piping } \\
\text { Systems, second edition. }\end{array}$ & $\begin{array}{l}\text { Discusses two methods for installing cathodic } \\
\text { protection to buried steel petroleum storage and } \\
\text { dispensing systems. Discusses the corrosion of } \\
\text { buried steel tank systems and how to protect } \\
\text { them using sacrificial anode protection and } \\
\text { impressed current protection. }\end{array}$ \\
\hline $\begin{array}{l}\text { API } 1650 \\
\text { Digest of Six API Recommended } \\
\text { Practices on Underground Petroleum } \\
\text { Storage Tank Management }\end{array}$ & $\begin{array}{l}\text { A bound version of the complete texts of API } \\
\text { Recommended Practices } 1604 \text { (removal), } 1615 \\
\text { (installation), } 1621 \text { (stock control), } 1628 \text { (spill } \\
\text { clean-up), } 1631 \text { (interior lining), and } 1632 \\
\text { (cathodic protection). }\end{array}$ \\
\hline
\end{tabular}




\begin{tabular}{|c|c|}
\hline \multicolumn{2}{|c|}{$\begin{array}{l}\text { American Society for Testing and Materials (ASTM) } \\
\text { American Society for Testing and Materials } \\
\text { 1916 Race Street } \\
\text { Philadelphia, PA } 19103 \\
\text { (215) 299-5400 }\end{array}$} \\
\hline $\begin{array}{l}\text { ASTM D4021-86 } \\
\text { Standard Specification for Glass-Fiber- } \\
\text { Reinforced Polyester Underground } \\
\text { Petroleum Storage Tanks. }\end{array}$ & $\begin{array}{l}\text { Includes standards for the manufacture, } \\
\text { installation, testing and use of glass-fiber- } \\
\text { reinforced polyester underground storage tanks. }\end{array}$ \\
\hline $\begin{array}{l}\text { ASTM E1526 } \\
\text { Standard Practice for Evaluating the } \\
\text { Performance of Release Detection Systems } \\
\text { for Underground Storage Tank Systems, } \\
\text { (Vol. } 1104 \text { of the Annual Book of ASTM } \\
\text { Standards). }\end{array}$ & $\begin{array}{l}\text { General procedure for evaluating and reporting } \\
\text { the evaluation results of a system designed to } \\
\text { detect releases from underground storage tanks } \\
\text { containing regulated substances. }\end{array}$ \\
\hline
\end{tabular}

\begin{tabular}{||c|c|}
\hline \multicolumn{2}{|c|}{$\begin{array}{c}\text { American Water Works Association (AWWA) } \\
\text { 6666 W. Quincy Avenue } \\
\text { Denver, CO 80235 } \\
\text { (303) 794-7711 }\end{array}$} \\
\hline $\begin{array}{l}\text { AWWA D-100 } \\
\text { Welded Steel Tanks for Water Storage } \\
\text { (AWS D5.2-84), 1984. }\end{array}$ & $\begin{array}{l}\text { Covers the minimum standards of the design } \\
\text { and construction of welded steel tanks for } \\
\text { water storage. }\end{array}$ \\
\hline
\end{tabular}




\begin{tabular}{||c|c||}
\hline \multicolumn{2}{|c|}{$\begin{array}{c}\text { National Association of Corrosion Engineers (NACE) } \\
\text { National Association of Corrosion Engineers } \\
\text { P. O. Box 218340 } \\
\text { Houston, TX 77218 } \\
\text { (713) 492-0535 }\end{array}$} \\
\begin{tabular}{|l|l||} 
NACE RP-0169-92 \\
$\begin{array}{l}\text { Control of External Corrosion on } \\
\text { Underground or Submerged Metallic }\end{array}$
\end{tabular} & $\begin{array}{l}\text { Covers design considerations; how to } \\
\text { determine the need for corrosion control; } \\
\text { coating information; how to keep corrosion } \\
\text { control records; and criteria, design, } \\
\text { installation, operation and maintenance of } \\
\text { cathodic protection systems. }\end{array}$ \\
\hline $\begin{array}{l}\text { NACE RP-0184-84 } \\
\text { Repair of Lining Systems }\end{array}$ & $\begin{array}{l}\text { Discusses the various equipment and material } \\
\text { needed for repairing lining systems. Covers } \\
\text { the cleaning of substrate and lining, surface } \\
\text { preparation and how to line with plastisol. }\end{array}$ \\
\hline $\begin{array}{l}\text { NACE RP-0285-85 } \\
\text { Buried, Partially Buried, or Submerged } \\
\text { Liquid Storage Systems. }\end{array}$ & $\begin{array}{l}\text { Contains recommended practices for } \\
\text { controlling external corrosion. Covers design } \\
\text { considerations; how to determine the need for } \\
\text { corrosion control; coating information; how to } \\
\text { keep corrosion control records; and criteria, } \\
\text { design, installation, operation and maintenance } \\
\text { of cathodic protection systems. }\end{array}$ \\
\hline
\end{tabular}




\begin{tabular}{|c|c|}
\hline \multicolumn{2}{|c|}{$\begin{array}{l}\text { National Fire Protection Association (NFPA) } \\
\text { National Fire Protection Association } \\
\text { Batterymarch Park } \\
\text { Quincy, MA 02269 } \\
\text { (800) 344-3555 }\end{array}$} \\
\hline $\begin{array}{l}\text { NFPA } 327 \\
\text { Cleaning or Safeguarding Small Tanks } \\
\text { and Containers }\end{array}$ & $\begin{array}{l}\text { Discusses cleaning and testing procedures for } \\
\text { small tanks that cannot be entered and that } \\
\text { have contained flammable or combustible } \\
\text { liquids, gases or solids. }\end{array}$ \\
\hline
\end{tabular}

\begin{tabular}{|l|l||}
\hline \multicolumn{2}{|c|}{ National Leak Prevention Association (NLPA) } \\
National Leak Prevention Association \\
4090 Rosehill Avenue \\
Cincinnati, OH 45229 \\
(208) 389-2074 \\
\hline NLPA Standard 631 & Discusses addition of liners to existing tanks to \\
Spill Prevention, Minimum 10-Year Life \\
Extension of Existing Steel Underground accidental leakage of contents. \\
Tanks by Lining Without the Addition of \\
Cathodic Protection.
\end{tabular}




\begin{tabular}{|c|c|}
\hline \multicolumn{2}{|c|}{$\begin{array}{l}\quad \text { Steel Tank Institute (STI) } \\
\text { Steel Tank Institute } \\
570 \text { Oakwood Road } \\
\text { Lake Zurich, IL } 60047 \\
\text { (708) 438-0989 }\end{array}$} \\
\hline $\begin{array}{l}\text { sti-P }{ }_{3}{ }^{\circledR} \text { Specification } \\
\text { Specifications for sti- } \mathrm{P}_{3}{ }^{\circledR} \text { System of } \\
\text { External Corrosion Protection of } \\
\text { Underground Steel Storage Tanks (1987) }\end{array}$ & $\begin{array}{l}\text { Addresses the design and fabrication of coated } \\
\text { and cathodically protected steel underground } \\
\text { storage tanks. }\end{array}$ \\
\hline $\begin{array}{l}\text { R892-91 } \\
\text { Recommended Practice for Corrosion } \\
\text { Protection of Underground Piping } \\
\text { Networks Associated with Liquid Storage } \\
\text { and Dispensing Systems. }\end{array}$ & $\begin{array}{l}\text { This recommended practice outlines the steps } \\
\text { in designing, installing and monitoring of } \\
\text { corrosion control systems for underground } \\
\text { metallic piping and includes a copy of NACE } \\
\text { RP0285-85. }\end{array}$ \\
\hline
\end{tabular}

\section{Underwriters Laboratories, Inc. (UL) \\ Underwriters Laboratories, Inc. \\ 333 Pfingsten Road \\ Northbrook, IL 60062 \\ (708) 272-8800}

UL 1316

Glass-Fiber-Reinforced Plastic

Underground Storage Tanks for Petroleum

Products (1983, Revised May 1991)

\section{UL 1746}

Corrosion Protection Systems for Underground Storage Tanks (1989, Revised November 1990)
Covers construction, performance, manufacture, testing and installation of spherical or horizontal cylindrical, atmospheric-type tanks of glass-fiber reinforced plastic.

Discusses various corrosion protection systems for steel underground storage tanks. 


\title{
APPENDIX D DATA SURVEY FORMS
}

\author{
Sandia Aging Management Guideline \\ Data Survey for Tanks and Pools
}

\section{Introduction}

This survey is intended to gatner data necessary to support the preparation of the Tanks and Pools Aging Management Guideline (AMG) under development as part of the Department of Energy (DOE) sponsored Plant Lifetime Program (PLIM), in cooperation with the Electric Power Research Institute (EPRI). AMGs resolve technical issues, support continued development of a stable license renewal process, and provide aging management insights for maintenance rule implementation.

\section{Scope of "Important" Tanks \& Pools}

Based on Yankee Rowe and Monticello lead plant license renewal efforts, maintenance rule Verification and Validation, and screening conducted as part of ongoing industry initiatives, a list of systems was selected as "important". Given a list of important systems, a preliminary list of important tanks and pools was generated by identifying which of the important systems have tanks/pools in them. An additional evaluation of the important tank and pool list identified 22 representative tanks and pools that will be subject to the AMG evaluation process.

The preliminary list of 22 tanks and pools is included on the attached host utility data survey forms. Due to the in-process AMG evaluations, host utilities are encouraged to perform the following:

- Identify additional tanks and pools that are important at their utility and list them on the blank survey forms that are attached.

- Review the list of 22 tanks and pools plus any added by the host utility to identify those tanks and pools that are "most important" to the host utility.

- Identify the basis (if any) for the "most important" tanks and pools. This basis will be covered during the host utility visit. Typical considerations include risk significance, prior problems, major modification, etc.

\section{Data Survey Structure}

The data survey has been design so that the cognizant system engineer can provide the data for his tanks and pools with a minimal effort. Attachment of supplemental information (eg drawings, specifications, computer lists, maintenance procedures, etc.) is encouraged to streamline the data collection process. All data survey forms and attached references will be reviewed as part of the host utility visit; therefore, data collection efforts should provide a good faith preparation effort for that visit. Data collection efforts should focus on retrieving the maximum information as efficiently as possible. Questionable or unavailable data can be discussed during the host utility visit. 
The tanks and pools AMG survey consists of two sections: "Basic" data and "Materials Data Survey". The "Basic" data survey (legal size paper) provides very basic design, operations and physical configuration data. Due to the simple response required for many of the data fields, detailed instructions are not provided. Notes have been added to provide clarifications for selected data fields.

The survey titled "Materials Data Survey" should identify materials of construction and backup attachment information. Individual tank and pool parts should be identified and supplemental parts lists attached where differences exist and the information is retrievable. A Typical parts breakdown could include the items noted below. "Material designation and grade" data field information is also provided as an illustration.

\section{Typical AMG Tank Parts}

$\underline{\text { Part }}$

Shell:

Nozzles

(inlet, outlet, overflow, instrument):

Vents/drains:

Heater Sheaths:

Liners, Bladders

(data field on "Basic" Data Survey)
Material

ASTM A-240 type 304 SS

ASTM A-312 type 304 SS

ASTM A-181 CS (with Plasite 7155)

Incoloy

BUNA-N bladder 
TANKS \& POOLS AGING MANAGEMENT GUIDELINE

Data Survey (Page 1 of 2)

Plant Data for

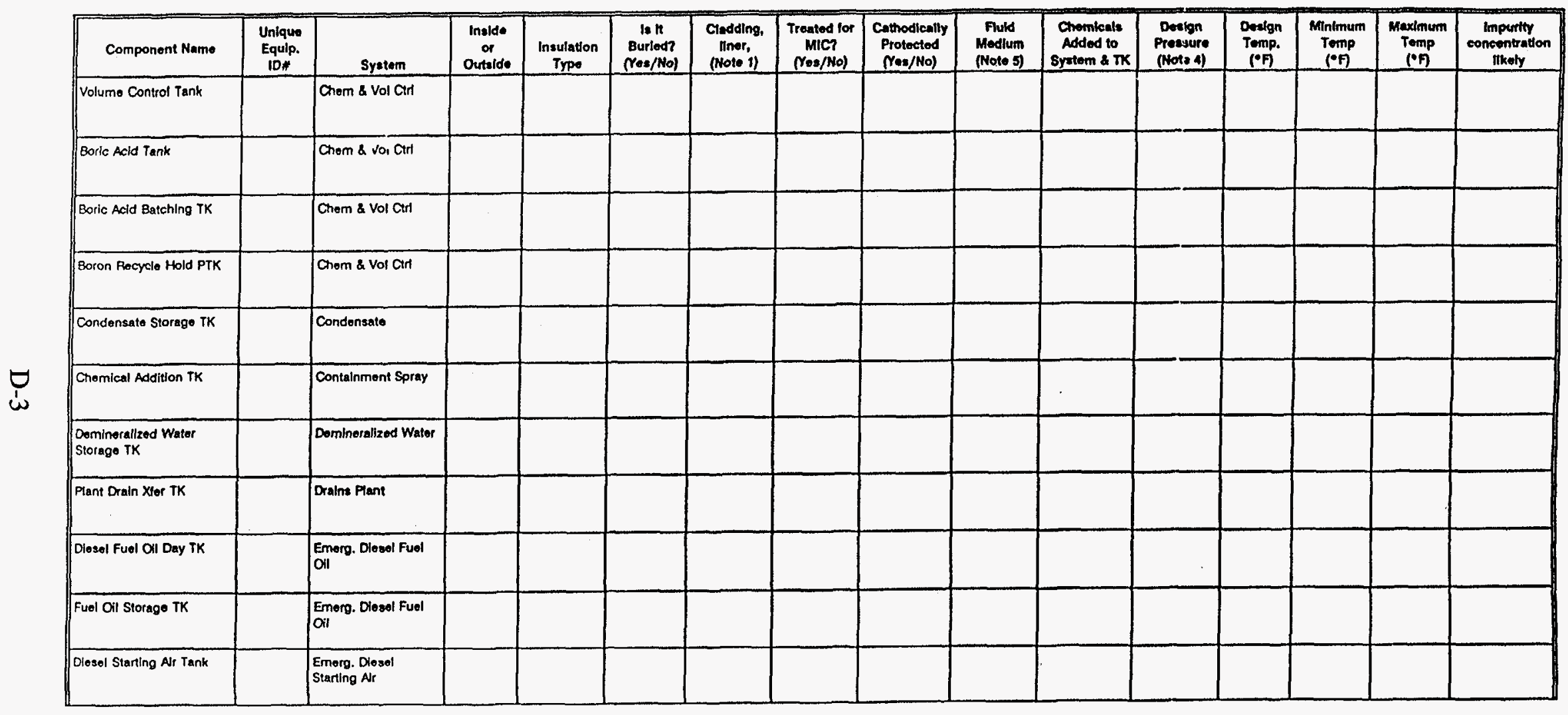




\begin{tabular}{|c|c|c|c|c|c|c|c|c|c|c|c|c|c|c|c|}
\hline & & & & & & & & & & & & & 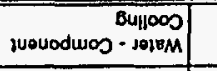 & & 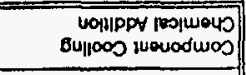 \\
\hline & & & & & & & & & & & & & 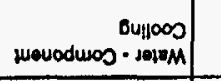 & & 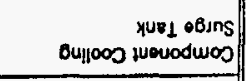 \\
\hline & & & & & & & & & & & & & pinbor - assem & & 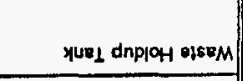 \\
\hline & & & & & & & & & & & & & pinbn - ousem & & 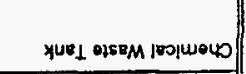 \\
\hline & & & & & & & & & & & & & wroos UIDEN & & 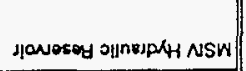 \\
\hline & & & & & & & & & & & & & jons woods & & 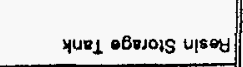 \\
\hline & & & & & & & & & & & & & pont wods & & 1000 dions uads. \\
\hline & & & & & & & & & & & & & ISD $7 / \mathrm{HH}$ H & & $X_{1}$ solannunow is \\
\hline & & & & & & & & & & & & & $\mid \mathrm{Sd} / \mathrm{HHH}+\mathrm{S}$ & & 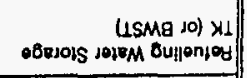 \\
\hline & & & & & & & & & & & & & 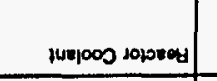 & & 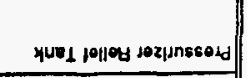 \\
\hline & & & & & & & & & & & & & 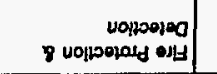 & & yure obroois solem asty \\
\hline 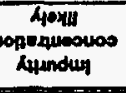 & $\begin{array}{c}\text { (G)) } \\
\text { dumpl } \\
\text { unnugrow }\end{array}$ & $\begin{array}{c}\text { God } \\
\text { dumpor } \\
\text { unnumum }\end{array}$ & 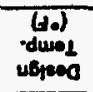 & 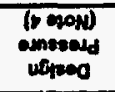 & 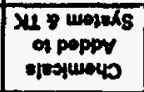 & $\begin{array}{l}\text { (s nown) } \\
\text { unppow } \\
\text { pins }\end{array}$ & 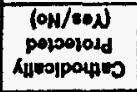 & 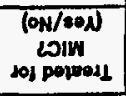 & 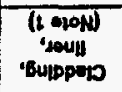 & 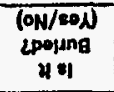 & $\begin{array}{c}\text { od od } 1 \\
\text { uoprynoul }\end{array}$ & $\begin{array}{l}\text { opionno } \\
\text { so } \\
\text { oppsuy }\end{array}$ & wolshs & $\begin{array}{c}\text { nal } \\
\text { dinnby } \\
\text { enblun }\end{array}$ & OWIEN zuoudwas \\
\hline
\end{tabular}




\section{NOTES}

NOTE 1: Identify if pool/tank uses cladding, liner or bladder. List material designation and/or grade.

NOTE 2: Attach reterences used to support data survey (e.g. drawings, specificatlons, maintenance procedures, etc.)

NOTE 3: Attach Service History and Maintenance Procedures as available. Service History should note date of last tank inspection (if any) NOTE 4: Design Pressure in psia - Also note "vented" if tank is vented to atmosphere

NOTE 5: Fluid mediums include water, diesel fuel, air, chemical (ist as glycol, etc.) 
TANKS \& POOLS AGING MANAGEMENT GUIDELINE

Materials Data Survey (Page 1 of 2)

Plant Data for

\begin{tabular}{|c|c|c|c|c|c|c|c|}
\hline Component Name & $\begin{array}{l}\text { Part } \\
\text { Name }\end{array}$ & $\begin{array}{c}\text { Material } \\
\text { Designation } \\
\text { and Grado }\end{array}$ & $\begin{array}{l}\text { Insido } \\
\text { Coating } \\
\text { Material }\end{array}$ & $\begin{array}{l}\text { Adjacent } \\
\text { Materials }\end{array}$ & $\begin{array}{l}\text { Attached } \\
\text { References } \\
\text { (Note 2) }\end{array}$ & $\begin{array}{l}\text { Attachod } \\
\text { Servlce } \\
\text { Hilstory } \\
\text { (Note 3) }\end{array}$ & $\begin{array}{l}\text { Attachod } \\
\text { Malntenance } \\
\text { Procedure } \\
\text { (Note 3) }\end{array}$ \\
\hline Volume Control Tank & & & & & & & \\
\hline Boric Acid Tank & & & & & & & \\
\hline Boric Acid Batching TK & & & & & & & \\
\hline Boron Recycle Hold PTK & & & & & & & \\
\hline Condensate Storage TK & & & & & & & \\
\hline Chemical Addition TK & & & & & & & \\
\hline $\begin{array}{l}\text { Deminerallzed Water } \\
\text { Storage TK }\end{array}$ & & & & & & & \\
\hline Plant Drain Xfer TK & & & & & & & \\
\hline Diesel Fuel OAl Day TK & & & & & & & \\
\hline Fuel Oll Storage TK & & & & & & & \\
\hline Diesel Starting Air Tank & & & & & & & \\
\hline
\end{tabular}


TANKS \& POOLS AGING MANAGEMENT GUIDELINE

Materials Data Survey (Page 2 of 2)

Plant Data for

\begin{tabular}{|c|c|c|c|c|c|c|c|}
\hline Component Name & $\begin{array}{l}\text { Part } \\
\text { Name }\end{array}$ & $\begin{array}{c}\text { Materlal } \\
\text { Designation } \\
\text { and Grade }\end{array}$ & $\begin{array}{l}\text { Inside } \\
\text { Coating } \\
\text { Materlal } \\
\end{array}$ & $\begin{array}{l}\text { Adjacent } \\
\text { Materlals }\end{array}$ & $\begin{array}{l}\text { Attached } \\
\text { References } \\
\text { (Nolo 2) }\end{array}$ & $\begin{array}{l}\text { Attached } \\
\text { Service } \\
\text { History } \\
\text { (Noto 3) } \\
\end{array}$ & $\begin{array}{c}\text { Attachod } \\
\text { Malntenance } \\
\text { Proceduro } \\
\text { (Note 3) } \\
\end{array}$ \\
\hline \multicolumn{8}{|l|}{ Fre Water Storage Tank } \\
\hline \multicolumn{8}{|l|}{ Pressurzer Relief Tank } \\
\hline \multicolumn{8}{|l|}{$\begin{array}{l}\text { Refueling Water Storage TK } \\
\text { (or.8WST) }\end{array}$} \\
\hline \multicolumn{8}{|l|}{ SI Accumulator TK } \\
\hline \multicolumn{8}{|l|}{ Spent Fuel Pool } \\
\hline \multicolumn{8}{|l|}{ Resin Storage Tank } \\
\hline \multicolumn{8}{|l|}{ MSN Hydraulic Reservoir } \\
\hline \multicolumn{8}{|l|}{ Chemical Waste Tank } \\
\hline \multicolumn{8}{|l|}{ Wasto Holdup Tank } \\
\hline \multicolumn{8}{|l|}{$\begin{array}{l}\text { Component Coolling Surge } \\
\text { Tank }\end{array}$} \\
\hline $\begin{array}{l}\text { Component Cooling } \\
\text { Chemical Addition }\end{array}$ & & & & & & & \\
\hline
\end{tabular}


TANKS \& POOLS AGING MANAGEMENT GUIDELINE

Materials Data Survey

Plant Data for

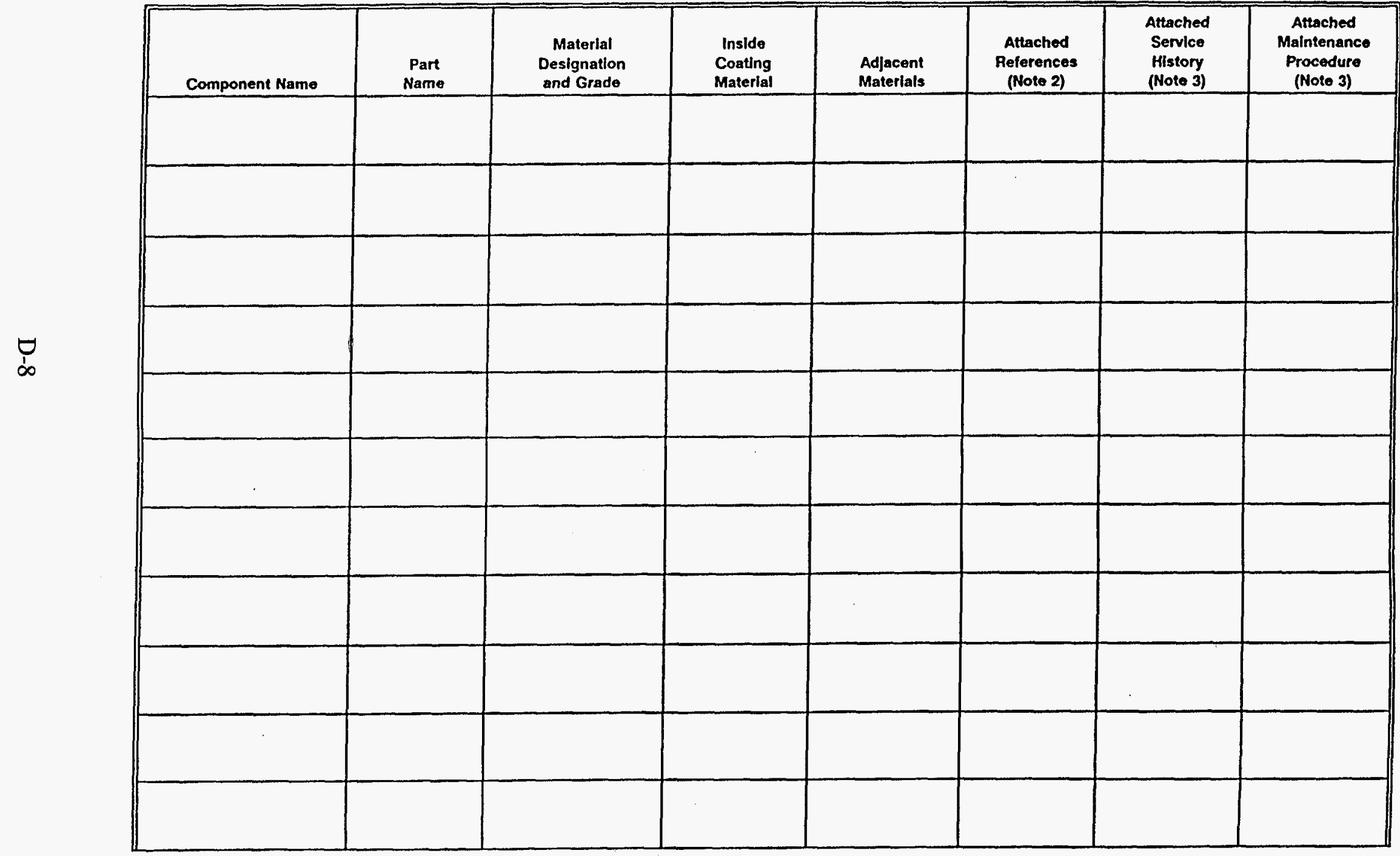


NOTES

NOTE 1: identify if pool/tank uses cladding, liner or bladder. List material designation and/or grade.

NOTE 2: Attach references used to support data survey (e.g. drawings, speciflcations, maintenance procedures, etc.)

NOTE 3: Attach Service History and Maintenance Procedures as avallable. Service History should note date of last tank Inspection (if any)

NOTE 4: Design Pressure in psia - Also note "vented" if tank is vented to atmosphere

NOTE 5: Fluid mediums include water, diesel fuel, air, chemical (iist as glycol, etc.) 



\section{APPENDIX E \\ NON-SIGNIFICANT AGING MECHANISM DESCRIPTIONS}

\section{E.1 Fatigue}

Fatigue results in subcritical crack growth under the influence of a fluctuating stress caused by applied loads or temperature. Fatigue failures can be either brittle or ductile, but often manifest as a sudden (and unexpected) failure due to lack of gross deformation during crack growth.

Fatigue behavior of a component is related to a variety of parameters, such as stress range, mean stress, frequency or cyclic wave form, environmental conditions, metallurgy of the material, and surface toughness of the material. Cracks typically initiate at local geometric stress concentration points such as notches, surface defects, and structural discontinuities. Material fatigue initiation curves have been developed to show how many stress cycles at specific stress amplitudes are required to initiate fatigue cracks.

When applied or induced loads are low enough so that more than 10,000 cycles are required to produce failure, the phenomenon is termed high-cycle fatigue. When applied or induced loads are high enough so that less than 10,000 cycles are required to produce failure, the phenomenon is termed low-cycle fatigue. The applied strain amplitude at the time of failure is sometimes used to differentiate between high- and low-cycle fatigue as opposed to the number of cycles. The low-cycle fatigue range is for strain levels typically above $0.225 \%$, the highcycle fatigue range is for strain levels typically below $0.225 \%$. When cyclic loads are produced by a fluctuating temperature, the process is termed thermal fatigue.

Environmental conditions also can affect fatigue initiation. The presence of corrosive conditions can accelerate fatigue crack initiation and propagation. For example, oxidation can produce pits in the surface of some alloys. The pits then act as stress concentrators and potential fatigue crack initiation sites. This is commonly called corrosion fatigue.

Summary for Fatigue:

Typical Nuclear Plant Component Types - All typical fluid system components subjected to large temperature or pressure changes or cyclic loadings.

Susceptible Materials - All typical power plant materials.

Typical Nuclear Plant Fluids - All fluid types.

Effects of Aging - Crack initiation.

Failure Modes - Seepage/leakage with the potential for rupture when high component stresses are present. 
For More Detailed Information - See Reference E.1, page 4-75.

\section{E.2 Irradiation Assisted Stress Corrosion Cracking (IASCC)}

IASCC occurs in highly irradiated material in high-temperature water containing shortlived oxidizing species produced by a gamma and neutron flux. Based on available field and laboratory data, a threshold fast neutron (energy $>1 \mathrm{MeV}$ ) fluence of approximately $5 \times 10^{20}$ neutrons $/ \mathrm{cm}^{2}$ for low-stressed ( $<10 \mathrm{ksi}$ ) components or $1 \times 10^{20} \mathrm{n} / \mathrm{cm}^{2}$ for highly stressed ( $>10 \mathrm{ksi}$ ) components is needed to produce IASCC in stainless steel or Inconel alloy 600 . Unlike IGSCC, IASCC does not require chromium depletion at the grain boundary or the presence of high tensile stress.

Summary for IASCC:

Typical Nuclear Plant Component Types - Only those components located in the reactor core.

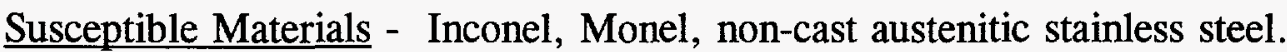

Typical Nuclear Plant Fluids - All types.

Effects of Aging - Cracking.

Failure Modes - Fracture of material.

For More Detailed Information - See References E.2; E.3.

\section{E.3 Embrittlement}

Elevated temperatures, contaminants, and radiation can cause embrittlement of metals and lead to rapid failures under dynamic loading. There are two predominant initiators of embrittlement that can affect nuclear plant components: (1) thermal embrittlement and (2) neutron embrittlement. Hydrogen damage also can embrittle metals, but is discussed in Section E.7 because of its unique characteristics.

\section{E.3.1 Thermal Embrittlement}

The mechanism of thermal embrittlement is complex and varies with material composition and service conditions. There are several types of thermal embrittlement that may influence nuclear plant components: $475^{\circ} \mathrm{C}\left[885^{\circ} \mathrm{F}\right]$ embrittlement of cast austenitic stainless steels, temper embrittlement, $350^{\circ} \mathrm{C}\left[500^{\circ} \mathrm{F}\right]$ embrittlement, blue brittleness, etc. The type of embrittlement experienced is dependent upon the material, special treatments performed during fabrication, and the system operating temperature. 


\section{E.3.1.1 $475^{\circ} \mathrm{C}$ Embrittlement of Cast Austenitic Stainless Steels (CASS)}

Fluid components made of CASS usually have from 5 to $20 \%$ ferrite distributed in discontinuous pools throughout the matrix. In ordinary service, where these steels may be heated in the range from 250 to $650^{\circ} \mathrm{C}$ [500 to $1200^{\circ} \mathrm{F}$ ], carbide precipitation occurs at the edges of the ferrite pools. If these pools are distributed so a continuous network is formed, embrittlement or a network of corrosion penetration may result. The fracture and impact toughness of the material may be reduced by this mechanism, and this may result in the rupture of highly stressed components.

Summary for $475^{\circ} \mathrm{C}$ Embrittlement of CASS:

Typical Nuclear Plant Component Types - Large pump casings, valve bodies, and large piping.

Susceptible Materials - Cast austenitic stainless steels.

Typical Nuclear Plant Fluids - All types.

Effects of Aging - Cracking.

Failure Modes - Seepage/leakage with the potential for rupture when high component stresses are present.

For More Detailed Information - See References E.2; E.4; E.1, pages 4-81, 30-33; E.5.

\section{E.3.1.2 Temper Embrittlement}

Temper embrittlement is a major cause of degradation of toughness of ferritic steels. Components otherwise in sound condition become candidates for retirement if they are severely embrittled. Temper embrittlement is encountered when components are exposed to temperatures in the range of 350 to $600^{\circ} \mathrm{C}$ [660 to $1110^{\circ} \mathrm{F}$ ]. Tempering, post-weld heat treatment, and exposure to operating temperatures in this range should be avoided.

Summary for Temper Embrittlement:

Typical Nuclear Plant Component Types - High temperature pressurizer components.

Susceptible Materials - Alloy steels.

Typical Nuclear Plant Fluids - All types.

Effects of Aging - Cracking.

Failure Modes - Seepage/leakage with the potential for rupture when high component stresses are present. 
For More Detailed Information - See References E.4; E.1, page 4-81.

\section{E.3.1.3 $350^{\circ} \mathrm{C}$ Embrittlement}

$350^{\circ} \mathrm{C}\left[500^{\circ} \mathrm{F}\right]$ embrittlement of quenched and tempered high strength, low alloy steels occurs over a temperature range of 200 to $370^{\circ} \mathrm{C}$ [ 390 to $700^{\circ} \mathrm{F}$. It occurs mainly in steels that have been heat treated to a micro-structure of tempered martensite; thus, the more descriptive term tempered-martensite embrittlement is sometimes used. Steels containing substantial amounts of chromium or manganese are highly susceptible to $350^{\circ} \mathrm{C}$ embrittlement. Aluminum contents above $0.04 \%$ reduce embrittlement, and additions of $0.1 \%$ aluminum usually eliminate the problem.

Summary for $350^{\circ} \mathrm{C}$ Embrittlement:

Typical Nuclear Plant Component Types - High temperature turbine components.

Susceptible Materials - Low alloy steels.

Typical Nuclear Plant Fluids - All types.

Effects of Aging - Cracking.

Failure Modes - Seepage/leakage with the potential for rupture when high component stresses are present.

For More Detailed Information - See References E.4; E.1, page 4-21.

\section{E.3.1.4 Blue Brittleness}

Blue brittleness occurs when plain carbon steels and some alloy steels are heated between 230 and $370^{\circ} \mathrm{C}$ [ 450 and $700^{\circ} \mathrm{F}$ ]. The result is an increase in strength and a marked decrease in ductility and impact strength. This phenomenon is known as blue brittleness because it occurs in the blue-heat range.

Summary for Blue Brittleness:

Typical Nuclear Plant Component Types - All typical fluid system components.

Susceptible Materials - Carbon steel and low alloy steels.

Typical Nuclear Plant Fluids - All types.

Effects of Aging - Cracking.

Failure Modes - Seepage/leakage with the potential for rupture when high component stresses are present. 
For More Detailed Information - See References E.6, page 202; E.4; E.1, pages 1-5, 4-81.

\section{E.3.1.5 Strain-Age Embrittlement}

If a low carbon steel is deformed, its hardness and strength will increase at room or slightly elevated temperature, but with a concurrent loss of ductility. Rimmed or capped sheet steels are particularly susceptible to strain-age embrittlement, although strain-aging also has been encountered in plate steel and weld heat-affected zones. The degree of embrittlement is a function of the amount of cold work, the aging temperature, and the time at temperature. Room temperature aging may require from a few hours to a year. However, as the aging temperature increases the required time decreases, with embrittlement occurring in a matter of minutes at about $200^{\circ} \mathrm{C}\left[400^{\circ} \mathrm{F}\right]$.

Summary for Strain-Age Embrittlement:

Typical Nuclear Plant Component Types - None, because cold working of components is not allowed by design codes and approved operating and maintenance practices.

Susceptible Materials - Carbon steel.

Typical Nuclear Plant Fluids - All types.

Effects of Aging - Cracking.

Failure Modes - Seepage/leakage with the potential for rupture when high component stresses are present.

For More Detailed Information - See Reference E.1, page 4-81.

\section{E.3.1.6 Graphitization Embrittlement}

Graphitization of carbon and carbon-molybdenum steel piping during service at temperatures above $425^{\circ} \mathrm{C}\left[800^{\circ} \mathrm{F}\right]$ has caused numerous failures in steam power plants and refineries. Graphite formation generally occurs in a narrow region in the heat-affected zone of a weld where the metal has been briefly heated above the lower critical temperature. The lower critical temperature is obtained from an iron-carbon phase diagram, and represents the lowest temperature at which a phase boundary exists.

The graphitization tendency of carbon and carbon-molybdenum steels is increased when the aluminum content exceeds $0.025 \%$. Steels deoxidized with silicon also may be susceptible to graphitization. Deoxidation with titanium usually will produce good resistance to graphitization. Carbon and carbon-molybdenum steels can be rendered less susceptible to graphitization by tempering just below the lower critical temperature. 
Summary for Graphitization Embrittlement:

Typical Nuclear Plant Component Types - None, because typical nuclear power plant operating systems do not operate at or above $425^{\circ} \mathrm{C}\left[800^{\circ} \mathrm{F}\right]$.

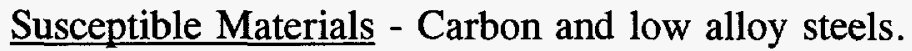

Typical Nuclear Plant Fluids - All types.

Effects of Aging - Cracking.

Failure Modes - Seepage/leakage with the potential for rupture when high component stresses are present.

For More Detailed Information - See Reference E.1, page 4-82.

\section{E.3.1.7 Sigma Phase Embrittlement}

The formation of sigma phase in ferritic and austenitic stainless steels during long periods of exposure to temperatures between 565 and $980^{\circ} \mathrm{C}$ [ 1050 and $1800^{\circ} \mathrm{F}$ ] results in considerable embrittlement after cooling to room temperature. Sigma phase, an iron-chromium compound, can be formed by either (a) slow cooling from temperatures of 1040 to $1150^{\circ} \mathrm{C}$ [1900 to $\left.2100^{\circ} \mathrm{F}\right]$ or (b) water quenching from 1040 to $1150^{\circ} \mathrm{C}$ [ 1900 to $\left.2100^{\circ} \mathrm{F}\right]$ followed by heating at 560 to $980^{\circ} \mathrm{C}$ [ 1040 to $1800^{\circ} \mathrm{F}$ ]. The embrittlement is most detrimental after the steel has cooled to $260^{\circ} \mathrm{C}\left[500^{\circ} \mathrm{F}\right]$.

Summary for Sigma Phase Embrittlement:

Typical Nuclear Plant Component Types - None due to absence of high operating temperatures.

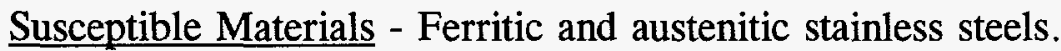

Typical Nuclear Plant Fluids - All types.

Effects of Aging - Cracking.

Failure Modes - Seepage/leakage with the potential for rupture when high component stresses are present.

For More Detailed Information - See Reference E.1, page 4-82.

\section{E.3.1.8 $400-500^{\circ} \mathrm{C}$ Embrittlement}

Fine-grained, high-chromium stainless steels normally possess good ductility. However, if they are held for long periods at temperatures in the range of 400 to $500^{\circ} \mathrm{C}$ [ 750 to $930^{\circ} \mathrm{F}$ ], they become harder and embrittled. Susceptibility to 400 to $500^{\circ} \mathrm{C}$ embrittlement increases with 
increasing chromium content, with the highest degree of embrittlement occurring at chromium contents greater than $19 \%$. At least $15 \%$ chromium is necessary for embrittlement to occur. High-chromium steels that contain at least $1 \%$ titanium are more susceptible to embrittlement than are similar steels with lower titanium contents. The embrittlement can be removed by soaking at somewhat higher temperatures for several hours.

Summary for $400-500^{\circ} \mathrm{C}$ Embrittlement:

Typical Nuclear Plant Component Types - None due to absence of high operating temperatures.

Susceptible Materials - Austenitic stainless steels.

Typical Nuclear Plant Fluids - All types.

Effects of Aging - Cracking.

Failure Modes - Seepage/leakage with the potential for rupture when high component stresses are present.

For More Detailed Information - See Reference E.1, page 4-81.

\section{E.3.2 Neutron Embrittlement}

Neutron embrittlement is a function of radiation exposure and environmental and metallurgical variables. Neutron fluence and copper and nickel content have been identified as the primary contributors. Important second order variables include neutron energy, temperature, and phosphorous content. There is evidence that a number of other variables such as heat treatment also influence neutron embrittlement. Available experimental data suggests that the following metallurgical properties of austenitic stainless steel result after prolonged exposure to neutrons:

- The yield strength increases by about a factor of 3 over its unirradiated value while the ultimate tensile strength remains essentially unchanged.

- The uniform elongation and the total elongation drop substantially from their unirradiated values.

- $\quad$ Fracture toughness drops by about a factor of 3 to 4 .

- $\quad$ Tearing modulus drops from several hundred to a range from 5 to 10 .

Experimental data also suggests that an accumulated fast neutron ( $>1 \mathrm{Mev}$ ) fluence of $1 \times 10^{20}$ neutrons $/ \mathrm{cm}^{2}$ is the threshold value where these metallurgical properties begin to change.[E.7, E.8, E.9] Ware and Shah[E.10] suggest this threshold is $1 \times 10^{19}$ neutrons $/ \mathrm{cm}^{2}$ for elongation and reduction in area and $1 \times 10^{20}$ neutrons $/ \mathrm{cm}^{2}$ for yield strength. 
Summary for Neutron Embrittlement:

Typical Nuclear Plant Component Types - Reactor vessel and other core components.

Susceptible Materials - Carbon and low alloy steels, ferritic and martensitic stainless steels, cast iron, Inconel, and austenitic stainless steel.

Typical Nuclear Plant Fluids - All types.

Effects of Aging - Loss of fracture toughness and tearing modulus, increase of yield strength.

Failure Modes - Seepage/leakage with the potential for rupture when high component stresses are present.

For More Detailed Information - See References E.4; E.11; E.12.

\section{E.4 Wear}

Wear is defined as damage to a solid surface by the removal or plastic displacement of material by the mechanical action of a contacting solid, liquid, or gas. There are three primary types of wear: adhesive wear, abrasive wear, and erosion.

\section{E.4.1 Adhesive Wear}

Adhesive wear also is known as scoring, galling, seizing, and scuffing and is characterized as transferring material from one surface to another caused by their relative motion.

Summary for Adhesive Wear:

Typical Nuclear Plant Component Types - Valve seats and discs and bearings.

Susceptible Materials - Copper alloys, aluminum alloys, and austenitic stainless steels.

Typical Nuclear Plant Fluids - All types.

Effects of Aging - Wall thinning, buildup of unwanted material.

Failure Modes - Degradation of critical component dimensions.

For More Detailed Information - See Reference E.1, page 4-63.

\section{E.4.2 Abrasive Wear}

Abrasive wear also is known as scoring and scuffing and is characterized as displacement of material from a solid surface due to hard particles sliding along the surface. Abrasive wear 
can be caused by loose particles trapped between moving surfaces or from hard particles carried by the fluid and impinging on the surface of the material.

Summary for Abrasive Wear:

Typical Nuclear Plant Component Types - All typical fluid system components.

Susceptible Materials - All typical power plant fluid system materials.

Typical Nuclear Plant Fluids - Water-based fluids not maintained free of abrasive materials (i.e., open cycle raw water cooling systems).

Effects of Aging - Wall thinning.

Failure Modes - Seepage/leakage.

For More Detailed Information - See Reference E.1, page 4-64.

\section{E.4.3 Erosion Wear}

Erosion is the destruction of metals or other materials by the abrasive action of fluids, usually accelerated by the presence of solid particles or matter in suspension. When corrosion occurs simultaneously, the term "erosion/corrosion" is often used. Erosion/corrosion was discussed in Section 4.2.3.

Summary for Erosion Wear:

Typical Nuclear Plant Component Types - All typical fluid system components.

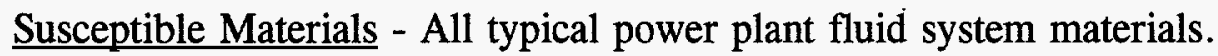

Typical Nuclear Plant Fluids - Water-based fluids not maintained free of abrasive materials (i.e., open cycle raw water cooling systems).

Effects of Aging - Wall thinning.

Failure Modes - Seepage/leakage.

For More Detailed Information - See Reference E.1, page 4-65.

\section{E.5 Stress Relaxation}

Stress relaxation is an elevated temperature aging mechanism important in the design of devices intended to hold components in contact under pressure. Stress relaxation occurs under elevated temperature conditions of constant strain. Materials loaded to an initial stress may experience a reduction in stress over time at high temperatures. The reduction in prestress 
generally occurs at a decreasing rate with the majority of loss occurring early in the life of the prestressed part.

Factors affecting stress relaxation are (1) material type, (2) neutron fluence, (3) time, (4) temperature, and (5) amount of initial prestress. For tanks and pools, the fast neutron fluence is not a factor due to location of these components relative to the reactor core. Stress relaxation is a concern only for materials that are subject to high initial prestress conditions and exposed to elevated temperatures for prolonged periods of time.

Summary for Stress Relaxation:

Typical Nuclear Plant Component Types - Bolting/fasteners.

Susceptible Materials - All typical power plant fluid system materials.

Typical Nuclear Plant Fluids - All fluid types.

Effects of Aging - Plastic deformation of loaded component.

Failure Modes - Loose parts, loss of preload.

For More Detailed Information - See Reference E.1, page 28-11.

\section{E.6 Creep}

Creep is defined as time-dependent strain, or gradual elastic and plastic deformation of metal that is under a constant stress at a value lower than its normal yield strength. The type of fracture (ductile or brittle) caused by creep depends on temperature and strain rate. The effect is particularly important if the component's operating temperature is near the recrystallization temperature of the metal.

Summary for Creep:

Typical Nuclear Plant Component Types - None, because design codes prevent components from operating at or near the component's metal recrystallization temperature.

Susceptible Materials - All typical power plant fluid system materials.

Typical Nuclear Plant Fluids - All fluid types.

For More Detailed Information - See Reference E.13; E.2; E.14, pages 63-64; E.15, page 78 ; E.1, page $15-13$. 


\section{E.7 References}

E.1 Metals Handbook Desk Edition, American Society for Metals, 1985.

E.2 "Component Life Estimation: LWR Structural Materials Degradation Mechanisms," M. E. Lapides, EPRI Report NP-5461, September 1987.

E.3 "Proceedings: 1986 Workshop On Advanced High Strength Materials, " EPRI Report NP-6363, May 1989.

E.4 "Environmental Effects on Components: Commentary for ASME Section III," S. W. Tagart, Jr., EPRI Report NP-5775, April 1988.

E.5 "LWR Experience With Centrifugally Cast Stainless Steel Pipe," S. N. Liu, EPRI Report NP-4996-LD, December 1986.

E.6 Engineering Materials And Their Applications, Richard A. Flinn and Paul K. Trojan, Houghton Mifflin Company, 1975.

E.7 EPRI Report TR-103839, "Boiling Water Reactor Vessel Internals License Renewal Industry Report," Revision 1, July 1994.

E.8 EPRI Report TR-103836, "Boiling Water Reactor Vessel License Renewal Industry Report," Revision 1, July 1994.

E.9 EPRI Report NP-3673-LD, "Long-Term Integrity of Nuclear Power Plant Components," October 1984, pp. 1-1, 2-44 through 2-50.

E.10 "Age Related Degradation of Boiling Water Reactor Vessel Internals," Nuclear Engineering and Design 133, A. G. Ware and V. N. Shah, 1992, pp. 49-62.

E.11 Title 10, U.S. Code of Federal Regulations, 10 CFR Part 50, Appendix G, "Fracture Toughness, and Appendix H, Reactor Vessel Material Surveillance Program Requirements," January 1, 1994.

E.12 U.S. Nuclear Regulatory Commission Regulatory Guide 1.99, "Radiation Embrittlement of Reactor Vessel Materials," Revision 2, May 1988.

E.13 Metallurgy of Welding, J. F. Lancaster, 1980.

E.14 Corrosion Control in the Chemical Process Industries, C. P. Dillon, McGrawHill, Inc., 1986.

E.15 Corrosion Engineering, Mars G. Fontana, McGraw-Hill, Inc., 1986. 
Distribution for Mechanical AMGs:

DOE

Dennis Harrison (5 copies)

U.S. Department of Energy, NE-50

19901 Germantown Road

Germantown, MD 20874

Sterling Franks, III

U.S. Department of Energy, NE-50

19901 Germantown Road

Germantown, MD 20874

Duli Agarwal

U.S. Department of Energy, NE-50

19901 Germantown Road

Germantown, MD 20874

Paul Wu (2 copies)

U.S. Department of Energy, NS-10 19901 Germantown Road

Germantown, MD 20874

$\underline{\text { EPRI }}$

John Carey (2 copies)

Electric Power Research Institute

3412 Hillview Avenue

Palo Alto, CA 94303

Michael Downs

EPRI NMAC

1300 Harris Boulevard

Charlotte, NC 28262

John Jenco ( 2 copies)

EPRI NMAC

1300 Harris Boulevard

Charlotte, NC 28262
EPRI Life Cycle Management Subcommittee

Barth Doroshuk (2 copies)

Baltimore Gas \& Electric

Calvert Cliffs

1650 Calvert Cliffs Parkway

Lusby, MD 20657

Jeb Kingseed

American Electric Power Service Corp.

1 Riverside Plaza

Columbus, OH 43215

L. Vaughn Wagoner

Carolina Power \& Light

P.O. Box 1551

Raleigh, NC 27612

Don Eggett (12 copies)

Commonwealth Edison Co.

1400 Opus Place, Suite 500

Downers Grove, IL 60515

Richard Remshaw (2 copies)

Consolidated Edison Co. of New York, Inc.

4 Irving Place, Rm. 1325

New York, NY 10003

Greg Robison (8 copies)

Duke Power Company, EC09F

P.O. Box 1006

Charlotte, NC 28201-1006

Bill Mackay (2 copies)

Entergy Operations, Inc.

GSB $/ 3 W$

1448 Star Route 333

Russellville, AR 72801

Robert Locke (3 copies)

GPU Nuclear Corporation

1 Upper Pond Road

Parsippany, NJ 07054 
Distribution for Mechanical AMGs (Con't)

Karl Jacobs (4 copies)

New York Power Authority

123 Main Street

White Plains, NY 10601

Michael Wadkins

Northeast Utilities

107 Seldon Street (MC W122)

Berlin, CT 06037

Fred Valentino

PECO Energy Company

Mail Code 63B-3

965 Chesterbrook Blvd.

Wayne, PA 19087

Jim Perrin (3 copies)

Public Service Electric \& Gas Co.

Nuclear Division MCN51

P.O. Box 236

Hancocks Bridge, N.J. 08038

George Wrobel

Rochester Gas \& Electric Corp.

89 East Avenue

Rochester, NY 14649

David Brevig

Southern California Edison Co.

P.O. Box 128

San Clemente, CA 92674

John Giddens (4 copies)

Southern Nuclear Operating Co.

P.O. Box 1295

Birmingham, AL 35201-1295

Jim Chardos (8 copies)

Tennessee Valley Authority

BR 4G-C

1101 Market Street

Chattanooga, TN 37402
Tony Marvray (3 copies)

Texas Utilities Electric Company

Comanche Peak

P.O. Box 1002

Glen Rose, TX 76043-1002

John Swailes

Washington Public Supply Power System 3000 George Washington Way, MD 927M

Richland, Washington 99352

Chuck Krause (2 copies)

Wisconsin Electric Power Company

P.O. Box 2046

Milwaukee, WI 53201

John Mortonson

Wisconsin Public Service Corp.

Nuclear Department

P.O. Box 19002

Green Bay, WI 54307-9002

Bill Szymzak

Yankee Atomic Electric Co.

580 Main Street

Bolton, MA 01740-1398

NSSS Owners Group Liaisons

Phil Richardson (2 copies)

ABB-CE Owners Group

P.O. Box 500

1000 Prospect Hill Road

Windsor, Conn 06095

Dave Firth (2 copies)

B\&W Owners Group GLRP Liaison

1700 Rockville Pike, Suite 525

Rockville, MD 20852 
Distribution for Mechanical AMGs (Con't)

Kathy Berry (2 copies)

BWR Owners Group GLRP Liaison

General Electric Nuclear Energy

175 Curtner Ave., MC 789

San Jose, CA 95125

Roger Newton (2 copies)

Westinghouse Owners Group GLRP Liaison

Wisconsin Electric Power Co.

231 West Michigan, P.O. Box 2046

Milwaukee, WI 53201

Institute of Nuclear Power Opns

James R. Bauman

Institute of Nuclear Power Opns

1100 Circle 75 Parkway, Suite 1500

Atlanta, GA 30339

\section{NRC Programs}

Jit Vora

U.S. Nuclear Regulatory Commission 5650 Nicholson Lane

Rockville, MD 20852

Ms. D.A. Jackson (2 copies)

Mail Stop OWFN O-11F23

U.S. Nuclear Regulatory Commission

11555 Rockville Pike

Rockville, MD 20852-2738

NEI

Doug Walters

Nuclear Energy Institute

1776 Eye Street, NW, Suite 300

Washington, DC 20006-2496

\section{$\underline{\text { Utilities }}$}

C. David Mauldin (3 copies)

Director-Maintenance

Palo Verde Nuclear Generating Station

Arizona Public Service Co.

P.O. Box 52034

Phoenix, AZ 85072-2034

Barry Tilden

Nuclear Engineering Department

Baltimore Gas \& Electric Co.

Calvert Cliffs Nuclear Power Plant

1650 Calvert Cliffs Parkway

Lusby, MD 20657-4702

T.J. Camilleri (2 copies)

Baltimore Gas \& Electric Co.

Calvert Cliffs Nuclear Power Plant

1650 Calvert Cliffs Parkway

Lusby, MD 20657-4702

Bruce Van Vleet

Manager, Maintenance Section

Pilgrim Unit 1

Boston Edison Co.

Nuclear Information Office

Rocky Hill Road

Plymouth, MA 02360

D.E. Young

General Manager - Robinson Nuclear Plant

Carolina Power \& Light Company

P.O. Box 790

Hartsville, S.C., 29550

Bill Lewis

Plant Manager - Unit 1

Brunswick Nuclear Power Plant

Carolina Power \& Light Co.

P.O. Box 10429

Southport, N.C. 28461 
Distribution for Mechanical AMGs (Con't)

C.C. Warren

Plant Manager - Unit 2

Brunswick Nuclear Power Plant

Carolina Power \& Light C0.

P.O. Box 10429

Southport, N.C. 28461

J.W. Donahue

General Manager

Harris Nuclear Power Plant

P.O. Box 165

New Hill, N.C. 27562

Vincent Sodd

Manager, Maintenance

Perry Nuclear Power Plant, Unit 1

Cleveland Electric Illuminating Co.

10 Center Road, Mail Zone MB 210

Perry, OH 44081

William Nevelos

Connecticut Yankee Atomic Power Co.

Station Services Director

Haddam Neck Nuclear Power Plant

362 Injun Hollow Rd.

Haddam Neck, Conn. 06424

John McCann

Manager, Maintenance

Consolidated Edison Co. of New York, Inc.

Indian Point 2 Nuclear Power Plant

Broadway and Bleakley Aves.

Buchanan, N.Y. 10511

Darryl Turner

Maintenance Manager

Big Rock Point Nuclear Power Plant

Consumers Power Company

10269 U.S. 31 North

Charlevoix, Mich. 49720
Richard Kasper

Maintenance Manager

Consumers Power Company

Palisades Plant

27780 Blue Star Highway

Covert, MI 49043

Steve Booker

Assistant Maintenance Superintendent

Fermi 2 Plant

Detroit Edison Company

6400 N. Dixie Hwy

Newport, MI 48166

S.C. Fenner ( 2 copies)

General Manager, Maintenance

Beaver Valley Plant

Duquesne Light Company

P.O. Box 4

Shippingport, PA 15122-0004

Randy Edington

Plant Manager, Unit 1

ANO 1

Entergy Operations, Inc.

Rte. 3, Box $137 \mathrm{G}$

Russellville, Ark. 72801

William Eaton

Plant Manager, Unit 2

ANO 2

Entergy Operations, Inc.

Rte. 3, Box $137 \mathrm{G}$

Russellville, Ark. 72801

Ron Moomaw

Entergy Operations, Inc.

Grand Gulf Nuclear Station

P.O. Box 756

Port Gibson, MS 39150 
Distribution for Mechanical AMGs (Con't)

Rob Starkey

Manager, Operations and Maintenance

Entergy Operations, Inc.

Waterford 3 Plant

P.O. Box B, Highway 18

Killona, La. 70066

E.C. Ewing

Manager, Maintenance

River Bend Plant

P.O. Box 220

St. Francisville, La. 70775

Ronald Davis

Manager, Nuclear Plant Maintenance

Florida Power Corp.

Crystal River 3 Nuclear Power Plant

15760 W. Power Line St.

Crystal River, FL 34428-6708

J. Marchese ( 2 copies)

Maintenance Manager

St. Lucie Units $1 \& 2$

Florida Power \& Light Co.

P.O. Box 128

Fort Pierce, Fla. 33454

R.G. Heisterman (2 copies)

Maintenance Manager

Turkey Point Units $3 \& 4$

Florida Power \& Light Co.

P.O. Box 4332

Princeton, Fla. 33032

Lewis Sumner (2 copies)

General Manager

Edwin Hatch Units 1 \& 2

Georgia Power Co.

P.O. Box 439

Baxley, Ga. 31513
James B. Beasley, Jr. (2 copies)

Plant General Manager

Vogtle Units 1 \& 2

Georgia Power Co.

P.O. Box 1600

Waynesboro, Ga., 30830

Terry Kuhn

GPU Nuclear

One Upper Pond Road

Parsippany, NJ 07054

S. Levin

Director of Operations and Maintenence

Oyster Creek Nuclear Power Plant

GPU Nuclear Corp.

Route 9

Forked River, N.J. 08731

Michael Ross

Director of Operations \& Maintenance

Three Mile Island Unit 1

GPU Nuclear Corp.

Route $441 \mathrm{~S}$

Londonderry Township

P.O. Box 480

Middletown, PA. 17057

R.J. Fast ( 2 copies)

Manager, Maintenance

South Texas Project Units 1 \& 2

Houston Lighting \& Power Co.

P.O. Box 289

Wadsworth, Tex. 77483

Gary Vanmiddlesworth

Plant Manager, Nuclear

Duane Arnold Plant

IES Utilities

Duane Arnold Energy Center

3277 DAEC Rd.

Palo, Iowa 52324 
Distribution for Mechanical AMGs (Con't)

William Clark

Director, Maintenance

Illinois Power Company

Clinton Unit 1 Power Station

P.O. Box 678

Clinton, IL 61727

T.P. Beilman ( 2 copies)

Indiana Michigan Power Co.

D.C. Cook Nuclear Power Plant Units 1 \& 2

One Cook Place

Bridgeman, MI 49106

R.L. Bickford

Manager, Maintenance

Maine Yankee Atomic Power Co.

Maine Yankee Nuclear Power Plant

P.O. Box 408

Wiscasset, ME 04578

Rick Gardner

Maintenance Manager

Nebraska Public Power District

Cooper Nuclear Power Plant

P.O. Box 98

Brownville, Nebr. 68321

William Yaeger

Manager, Unit 1 Engineering

Nine Mile Point Plant

Niagara Mohawk Power Corp.

Lake Rd., P.O. Box 32

Lycoming, NY 13093

Keith Ward

Manager, Unit 2 Engineering

Nine Mile Point Plant

Niagara Mohawk Power Corp.

Lake Rd.

P.O. Box 32

Lycoming, NY 13093
Jerry Peterson

Manager, Maintenance

Seabrook Nuclear Power Plant

North Atlantic Energy Service Corp.

P.O. Box 300

Seabrook, N.H. 03874

Peter Przekop

Unit 1 Director

Millestone Unit 1

Northeast Utilities

P.O. Box 128

Waterford, Conn. 06385

Gary Bouchard

Unit 2 Director

Millestone Unit 2

Northeast Utilities

P.O. Box 128

Waterford, Conn. 06385

Michael Brothers

Unit 3 Director

Millestone Unit 3

Northeast Utilities

P.O. Box 128

Waterford, Conn. 06385

Mike Hammer

General Superintendent, Maintenance

Monticello Nuclear Generating Plant

Northern States Power Co.

P.O. Box 600

Monticello, MN 55362

George Lenertz ( 2 copies)

General Superintendent, Maintenance

Prairie Island Units $1 \& 2$

Northern States Power Co.

1717 Wakonade Dr. E. (Rte. 2)

Welch, Minn. 55089 


\section{Distribution for Mechanical AMGs (Con't)}

H.J. Faulhaber

Supervisor - Maintenance

Fort Calhoun Unit 1

Omaha Public Power District

P.O. Box 399

Fort Calhoun, Nebr. 68023

Robert McDevitt ( 2 copies)

Nuclear Operations Support Dept.

Pacific Gas \& Electric Co.

77 Beale Street, Rm. 1414

San Francisco, CA 94106

Harry Phillips

Director - Technical Maintenance

Diablo Canyon Units $1 \& 2$

Pacific Gas \& Electric Co.

P.O. Box 56

Avila Beach, Calif. 93424

David Oatley

Director - Mechanical Maintenance

Diablo Canyon Units 1 \& 2

Pacific Gas \& Electric Co.

P.O. Box 56

Avila Beach, Calif. 93424

Daryl LeQuia (2 copies)

Director, Maintenance

Peach Bottom Units 2 \& 3

PECO Energy Co.

R.D. \#1, Box 208

Delta, Pa. 17314

Edward Sproat, III (2 copies)

Director, Maintenance

Limerick Units 1 \& 2

PECO Energy Co.

Evergreen \& Sanatoga Rds.

P.O. Box 2300

Sanatoga, Pa. 19464
Theodore Dalpiaz (2 copies)

Manager - Nuclear Maintenance

Susquehana Units $1 \& 2$

Pennsylvania Power \& Light Company

P.O. Box 467

Berwick, Pa. 18603

Michael Metcalf ( 2 copies)

-Maintenance Manager - Mechanical

Salem Units 1 \& 2

Public Service Electric \& Gas Co.

P.O. Box 236

Hancocks Bridge, N.J. 08038

Martin Trum

Maintenance Manager

Hope Creek Plant

Public Service Electric \& Gas Co.

P.O. Box 236

Hancocks Bridge, N.J. 08038

John Hotchkiss

Manager, Mechanical Maintenance

R.E. Ginna Plant

Rochester Gas \& Electric Co.

1503 Lake Rd.

Ontario, NY 14519

S.J. Furstenberg

Manager, Maintenance Services

Virgil C. Summer Plant

South Carolina Electric \& Gas Co.

P.O. Box 88

Jenkinsville, SC 29065

J. Fee ( 2 copies)

Manager, Maintenance

San Onofre Units $2 \& 3$

Southern California Edison Co.

P.O. Box 128

San Clemente, Calif. 92674-0128 


\section{Distribution for Mechanical AMGs (Con't)}

Donald Crouch

Superintendent, Mechanical Maint. Serv.

Davis-Besse Unit 1 Plant

Toledo Edison Co.

5501 N. State Route 2

Oak Harbor, Ohio 43449

John A. Fehl

Toledo Edison Co.

Davis-Besse Nuclear Power Station

300 Madison Avenue

Mail Stop: 1056

Toledo, OH 43652

Jerry Hogg

Superintendent, Maintenance

Calloway Plant

Union Electric Company

P.O. Box 620

Fulton, Mo. 65251

Greg Maret

Operations Superintendent

Vermont Yankee Plant

Vermont Yankee Nuclear Power Corp.

Governor Hunt Rd.

P.O. Box 157

Vernon, Vt. 05354

R.H. Blount II (2 copies)

Superintendent, Maintenance

Surry Plant Units $1 \& 2$

Virginia Power

5570 Hog Island Rd.

Surry, Va. 23883-0315

R.V. Shears ( 2 copies)

Superintendent, Maintenance

North Anna Units 1 \& 2

Virginia Power

P.O. Box 402

Mineral, Va. 23117
M. M. Monopoli

Maintenance Division Manager

WNP-2

Washington Public Power Supply System P.O. Box 968

Richland, WA 99352-0968

Jim Schweitzer ( 2 copies)

Manager, Maintenance

Wisconsin Electric Power Co.

Point Beach Unit 1 \& 2

6610 Nuclear Road

Two Rivers, WI 54241

John Richmond (2 copies)

Wisconsin Public Service

P.O. Box 19002

600 North Adams St.

Green Bay, WI 54307

Richard Repshas

Assistant Manager - Plant Maintenance

Kewaunee Plant

Wisconsin Public Service Corp.

North 490, Hwy. 42

Kewaunee, Wis. 54216-9510

C.W. Fowler

Manager, Maintenance and Modifications

Wolf Creek Nuclear Operating Plant

Wolf Creek Nuclear Operating Corp.

P.O. Box 411

Burlington, KS 66839

NSSS Vendors and Consultants

Bert Johnson

P.O. Box 999

Batelle Northwest Laboratory

MS P8-10

Richland, WA 99352 
Distribution for Mechanical AMGs (Con't)

Hunt Armistead (2 copies)

City of Austin, Electrical Department

721 Barton Springs Road

Austin, Texas, 78704

Herbert Massie, Jr.

Defense Nuclear Facilities Safety Board

625 Indiana Ave., NW, Suite 700

Washington, D.C., 20004

Vic Miselis

MDC-Ogden Environmental and Energy

Services

29200 Southfield Road, Suite 103

Southfield, MI 48076

Brij M. Bharteey

Spectrum Technologies

133 Wall Street

Schenectady, NY 12305

Paul Yela

Westinghouse Idaho Nuclear Company

MS5231, P.O. Box 4000

Idaho Falls, ID 83415

Attn: Gina Bailey

Authors

Eric Blocher

Parsons Power

2675 Morgantown Road

Reading, PA 19607

Lloyd Philpot

Parsons Power

2675 Morgantown Road

Reading, PA 19607

James Conley

Parsons Power

2675 Morgantown Road

Reading, PA 19607
Stan Smith

Yankee Atomic Electric Company

580 Main Street

Bolton, MA 01740

$\underline{\text { Sandia (Internal) }}$

MS 0736 N. R. Ortiz (6400)

MS 0741 A. K. Moonka (6471)

MS 0741 J. M. Clauss (6471)

MS 0741 J. T. Nakos (6471) (15 copies)

MS 0899 Technical Library (4414) (5 copies)

MS 0619 Print Media (12615)

MS 9018 Central Technical Files (8523-2)

MS 0100 Document Processing 7613-2 for DOE/OSTI ( 2 copies) 